\title{
Transcriptoma, Sítios de Ligação para Fatores de Transcrição e Região Promotora de cana-de-açúcar
}

\author{
Mauro de Medeiros Oliveira
}

\section{TESE APRESENTADA}

$\mathrm{AO}$

Instituto DE MATEMÁtica e EstatísticA

DA

Universidade DE SÃo PAUlo

PARA

OBTENÇÃO DO TÍTULO

$\mathrm{DE}$

Doutor EM CiÊnCIAS

Programa: Programa Interunidades de Pós-Graduação em Bioinformática

Orientadora: Profa. Dra. Glaucia Mendes Souza

Coorientador: Prof. Dr. Alan Mitchell Durham

Durante o desenvolvimento deste trabalho o autor recebeu auxílio financeiro da CAPES 


\section{Transcriptoma, Sítios de Ligação para Fatores de Transcrição e Região Promotora de cana-de-açúcar}

Esta versão da tese contém as correções e alterações sugeridas pela Comissão Julgadora durante a defesa da versão original do trabalho, realizada em 26/09/2018. Uma cópia da versão original está disponível no Instituto de Matemática e Estatística da Universidade de São Paulo.

Comissão Julgadora:

- Prof ${ }^{\mathrm{a}}$. Dr ${ }^{\mathrm{a}}$. Glaucia Mendes Souza - IQ-USP

- Prof. Dr. Marcos Silveira Buckeridge - IB-USP

- Prof ${ }^{a}$. Dra ${ }^{\mathrm{a}}$. Helaine Carrer - Esalq-USP

- Prof. Dr. Gabriel Rodrigues Alves Margarido - Esalq-USP

- Prof. Dr. Marcelo Falsarella Carazzolle - IB-UNICAMP 


\section{Agradecimentos}

A agência de fomento Capes pela bolsa de estudos no doutorado durante todo o curso.

A USP e o IME pelo curso de pós graduação em Bioinformática.

A FAPESP pelo apoio financeiro nos congressos e pela infraestrutura computacional dos laboratórios: Transdução de Sinais Bioquímica/IQ (Processo temático 2014/50921-8) e rede eScience-IME (2011 / 50761-2, CNPq, CAPES, NAP eScience - PRP - USP).

A professora Glaucia Souza e o Professor Alan Durham pela orientação, paciência e confiança no meu trabalho durante estes 4 anos.

Aos colegas de pesquisa em bioinformática Almir, Bruno, Carlos Henrique, Renato, Pedro e Ígor pela convivência e aprendizado profissional. Em especial ao colega Ígor pela parceria no desenvolvimento da ferramenta TSSFinder.

Ao laboratório de Transdução de Sinais: Alessandra, Augusto, Carol, Danielle, Davi, Felipe, Milton, Pablo e Sávio.

A minha Mãe, Maria Necilia, pelo apoio moral e financeiro durante este período de estudos. Aos meus irmãos Amauri, Adonias, Valdelei, Mário e Juary pela força, apoio moral e pensamento positivo.

A minha esposa Ana Gabriela Lobo pela cumplicidade, respeito e amor incondicional. Você sempre será o meu Sol. . .

Agradeço ao povo brasileiro, sem a contribuição financeira de vocês este trabalho não poderia ser realizado.

Zambi, Oxalá e todos os meus orixás. Okê Bamba Ocline!!! Assindé!! 


\section{Resumo}

OLIVEIRA, M. M. Transcriptoma, Sítios de Ligação para Fatores de Transcrição e Região Promotora de cana-de-açúcar. 2018. 137 f. Tese (Doutorado) - Programa Interunidades de Pós-Graduação em Bioinformática, Universidade de São Paulo, São Paulo, 2018.

O Brasil tem a maior produção de cana-de-açúcar do mundo. O cultivo de cana-de-açúcar no Brasil está voltado principalmente para a produção de açúcar ou Etanol e nos últimos anos para a produção de bioeletricidade através da utilização da biomassa do bagaço e da palha. Apesar da importância econômica e do potencial sustentável que a cana-de-açúcar apresenta, o genoma de referência para esta cultura ainda não está disponível na literatura. A principal justificativa para isso está na complexidade do mesmo, em especial pela alopoliploidia e autopoliploidia. De fato esta característica é a principal barreira para o desenvolvimento de novas variedades comerciais. Na literatura há diferentes estratégias que visam contribuir com o conhecimento genômico de cana-de-açúcar sendo mais prevalente dados de transcriptoma e pouca informação sobre o processo de regulação gênica. Além disso, diferente do que é observado em outras culturas comerciais, em cana-de-açúcar não há trabalhos associados com a caracterização in silico da região Promotora, assim como na identificação de sítios de ligação para Fatores de Transcrição (TFBSs). Por esta razão, o nosso trabalho foi direcionado para a caracterização in silico de regiões regulatórias em cana-de-açúcar. Para esta tarefa nós realizamos apenas a rotulação de sequências de DNA não codificante que estavam a upstream de cada gene anotado em cana-de-açúcar. Todos os genes foram selecionados de dados de transcriptoma e a sequência de DNA da região Promotora foi isolada do Genespace de cana-de-açúcar SP80-3280 gerado pelo projeto de sequenciamento do genoma de referência do nosso grupo. A rotulação da região regulatória em cana-de-açúcar foi executada em duas subsequências: Core Promoter e Promotor Proximal. Na região Core Promoter nós realizamos a identificação do sítio de inicio de transcrição (TSS), a estimativa do tamanho da região 5'UTR e a classificação da região Core Promoter em TATA-box ou TATA-less. Todos os processos foram realizados através da ferramenta TSSPlant. A utilização da ferramenta TSSPlant motivou o desenvolvimento de uma nova ferramenta para predição do sinal de TSS que aqui chamamos de TSSFinder. A ferramenta TSSinder apresentou resultados de predição do sinal de TSS superior aos seus pares, além disso esta ferramenta foi bem sucedida em diferentes organismos como Arabidopsis thaliana, Gallus gallus e Saccharomyces cerevisiae. Na região Promotora Proximal nós realizamos a 
identificação de TFBSs através de duas metodologias: predição de novo e mapeamento de matrizes de TFBS (PSSM). O processo de predição de novo foi realizada por meio de dois modelos: Maximização da expectativa e Gibbs Sampler e esse processo foi executado apenas para o subgrupo de genes co-expressos ou apenas para o conjunto de sequências homeólogas de cada gene de cana-de-açúcar selecionado. Para o restante das sequências foi realizado apenas o mapeamento das matrizes de TFBSs identificadas durante o processo de predição de novo. Em paralelo todos TFBSs identificados no nosso trabalho foram comparados com o banco de TFBS para plantas. Através desse procedimento foi possível estimar qual classe de Fator de Transcrição está interagindo com o TFBS identificado na região Promotora Proximal dos genes $S c d r 1, S c S u S y, S c P A L$. Com este trabalho, nós cobrimos parte da lacuna observada em estudos in silico paras regiões regulatórias de cana-de-açúcar. Além disso, nós aperfeiçoamos o processo de identificação do sinal de TSS para diferentes organismos; inclusive para plantas Dicotiledôneas e Monocotiledôneas.

Palavras-chave: Cana-de-açúcar, predição ab initio de TSS, predição de novo de TFBS, Core promoter e Promotor Proximal, caracterização in silico da região Promotora. 


\section{Abstract}

\section{OLIVEIRA, M. M. Transcriptome, Transcription Factors Binding Sites, and Su-}

garcane Promoter Region. 2018. 137 f. Tese (Doutorado) - Programa Interunidades de Pós-Graduação em Bioinformática, Universidade de São Paulo, São Paulo, 2010.

Brazil has the highest production of sugarcane in the world. It's cultivation in Brazil is aimed at producing of sugar or ethanol and in recent years, biomass for bioenergy from bagasse and straw. Despite the economic importance and the sustainable potential that sugarcane presents, a reference genome for this crop is not yet available in the literature. One justification for this absence lies in the sugarcane genome complexity, allopolyploidy and autopolyploidy. In fact these characteristics are the main barrier for the development of new commercial varieties. In the literature different strategies aimed at contributing to genomic sugarcane mostly on the transcriptome and little information on the process of gene regulation. Furthermore, unlike other commercial crops, sugarcane has no reported in silico characterization of its promoter regions and identification of Transcription Factor binding sites. For this reason, our work was directed to an in silico characterization of regulatory regions in sugarcane. For this task we performed the labeling of non-coding DNA sequences that were upstream of each gene annotated in sugarcane. All genes were using from transcriptome data and the promoter region DNA sequence was isolated from Genespace of the SP80-3280 reference genome obtained of our group. The labeling of the regulatory region in sugarcane was carried out in two subsections: Core Promoter and Proximal Promoter. In the Core Promoter region we performed the identification of the TSS signal, the estimation of the size of the 5'UTR region and the classification of the Core Promoter region in TATA-box or TATA-less. All processes were performed using the TSSPlant tool. The use of the TSSPlant tool motivated the development of a new tool to predict the TSS signal that we call TSSFinder. The TSSinder tool presented TSS signal prediction results superior to its peers, moreover this tool was successful in different organisms - Arabidopsis thaliana, Gallus gallus and Saccharomyces cerevisiae. In the Proximal Promoter region we performed the identification of TFBSs through two methodologies: de novo prediction and mapping of TFBS matrices (PSSM). The de novo prediction process was performed using two models: Expectancy Maximization and Gibbs Sampler and this process was performed only for subgroups of coexpressed genes or only for the set of homeologues sequences from each sugarcane gene. For the rest of the sequences only the mapping of the matrices of TFBSs identified during the de novo prediction process was conducted. In parallel all TFBSs identified in 
our work were compared with the TFBS database for plants. Through this procedure it was estimated which class of Transcription Factor is interacting with the TFBS identified in the Proximal Promoter region of the Scdr1, ScSuSy, ScPAL genes. With this work, we cover part of the gap observed in in silico studies for the regulatory region of sugarcane. In addition, we improved the process of identification the TSS signal for different organisms including dicotyledonous and monocotyledonous plants.

Keywords: Sugarcane, ab initio prediction of TSS, de novo prediction of TFBS, Core promoter and Proximal Promoter, in silico characterization of promoter region. 


\section{Sumário}

Lista de Abreviaturas $\quad$ xi

Lista de Figuras $\quad$ xiii

Lista de Tabelas $\quad$ xvii

1 Introdução $\quad 1$

1.1 Cana-de-açúcar . . . . . . . . . . . . . . . . . . . . . . . . 1

1.1.1 Histórico . . . . . . . . . . . . . . . . . . . . . . . 1

1.1.2 Caráter Botânico e Genético . . . . . . . . . . . . . . . . . . . 3

1.1.3 Caráter Econômico . . . . . . . . . . . . . . . . . . . . . 4

1.1.4 Sequências de DNA de cana-de-açúcar . . . . . . . . . . . . . . . . 6

1.2 Regulação Gênica . . . . . . . . . . . . . . . . . . . . . . . . 7

1.2.1 Fatores de Transcrição . . . . . . . . . . . . . . . . . . 8

1.2 .2 Sequências Regulatórias . . . . . . . . . . . . . 8

1.3 Região Promotora . . . . . . . . . . . . . . . . . . . . . . . . . 10

1.3.1 Core Promoter . . . . . . . . . . . . . . . . 13

1.3 .2 Promotor Proximal . . . . . . . . . . . . . . . . . . . . . 14

1.4 Identificação in vivo do sinal de TSS . . . . . . . . . . . . . . . . . . . . . . 14

1.5 Identificação in silico do sinal de TSS . . . . . . . . . . . . . . . . . . . . . . 15

1.6 Sítios de ligação para Fator de Transcrição . . . . . . . . . . . . . . . . . . 17

1.6.1 Principais características para rotulação de TFBS . . . . . . . . . . . 17

1.6.2 Cis-Regulatory Module . . . . . . . . . . . . . . . . . . . 17

1.7 Identificação de TFBS usando ensaios biológicos . . . . . . . . . . . . . . . . 18

1.7.1 Identificação in vitro de TFBS . . . . . . . . . . . . . . . . . . . . . . 18

1.7 .2 Identificação in vivo de TFBS . . . . . . . . . . . . . . . . . . . . . . 18

1.8 Identificação in silico de TFBS . . . . . . . . . . . . . . . . . . . . . . . . . 19

1.8.1 Mapeamento de TFBS . . . . . . . . . . . . . . . . . 20

1.8.2 Mapeamento usando TFBS anotados . . . . . . . . . . . . . . . . 21

1.8.3 Mapeamento usando sequências consenso ou k-mers . . . . . . . . . . 21

1.8.4 Mapeamento usando sobre-representação de TFBS . . . . . . . . . . 21

1.8.5 Mapeamento de TFBSs usando relação filogenética . . . . . . . . . . . 22 
1.8.6 Mapeamento com diferentes TFBSs - Clusters de TFBSs . . . . . . . 22

1.9 Predição de novo de TFBS . . . . . . . . . . . . . . . . . . . . . . . . . 22

1.9.1 Modelo de Maximização da Expectativa . . . . . . . . . . . . . . 23

1.9.2 Modelo Gibbs Sampling . . . . . . . . . . . . . . . . . . 23

1.10 Predição ab initio de TFBS . . . . . . . . . . . . . . . . . . . . . . . . . 24

1.10.1 Cadeias Ocultas de Markov . . . . . . . . . . . . . . . . . . . 24

2 Material e Métodos $\quad 27$

2.1 Seleção de sequências de DNA . . . . . . . . . . . . . . . . . . . . . 27

2.1.1 Genes de interesse em cana-de-açúcar . . . . . . . . . . . . . . 27

2.1.2 Transcriptoma de cana-de-açúcar . . . . . . . . . . . . . . . 28

2.2 Dados de sequências e de expressão de cana-de-açúcar . . . . . . . . . . . . . . 29

2.2.1 SUCEST-FUN . . . . . . . . . . . . . . . . . . . . . . . 29

2.2 .2 RNA-Seq de cana de açúcar . . . . . . . . . . . . . . . . . 29

2.3 Sequências de TSS . . . . . . . . . . . . . . . . . . . . 30

2.4 Workflow para identificação da região Promotora . . . . . . . . . . . . . . . 31

2.4.1 Análise da região Core Promoter . . . . . . . . . . . . . . . . . . . . 33

2.4 .2 Análise da região Promotora Proximal . . . . . . . . . . . . . . 33

2.5 TSSFinder - Predição ab initio do sinal de TSS . . . . . . . . . . . . . . . 35

2.5.1 Modelagem probabilística Linear-chain CRF . . . . . . . . . . . 35

2.5.2 Validação da ferramenta TSSFinder . . . . . . . . . . . . . . . . 36

2.5.3 Comparação do TSSFinder com outras ferramentas . . . . . . . . . . 37

$\begin{array}{llr}3 & \text { Objetivos } & 39\end{array}$

4 Resultados $\quad 41$

4.1 Análise in silico da região Promotora de cana-de-açúcar . . . . . . . . . . . . . 41

4.1.1 Caracterização do Core Promoter dos genes homeólogos Scdr1 . . . . 42

4.1.2 Rotulação do Promotor Proximal dos genes homeólogos Scdr1 . . . . 42

4.1.3 Caracterização do Core Promoter dos genes homeólogos ScSuSy . . . 42

4.1.4 Rotulação do Promotor Proximal dos genes homeólogos ScSuSy . . . 44

4.1.5 Caracterização do Core Promoter dos genes homeólogos ScPAL . . . 46

4.1.6 Rotulação do Promotor Proximal dos genes homeólogos ScPAL . . . 47

4.2 RNA-Seq de cana de açúcar . . . . . . . . . . . . . . . . . . . 48

4.2.1 Identificação dos genes expressos no Transcriptoma de cana-de-açúcar 48

4.2.2 Identificação de genes co-expressos no Transcriptoma de cana-de-açúcar 49

4.2 .3 Análise da região Promotora de genes co-expressos . . . . . . . . . . 49

4.3 TSSFinder preditor do sinal de TSS em eucariotos . . . . . . . . . . . . . . 50

4.3 .1 Validação do modelo . . . . . . . . . . . . . . . . 50

4.3.2 TSSFinder vs outras ferramentas . . . . . . . . . . . . . . . . . 53

4.3 .3 Determinação do conjunto de treinamento . . . . . . . . . . . . . . . 54 
5 Discussão $\quad 73$

5.1 Análise da região Promotora em cana-de-açúcar . . . . . . . . . . . . . . . . 73

5.1.1 Sugarcane drought-responsive 1 - Scdr1 . . . . . . . . . . . 73

5.1.2 Sugarcane Sucrose Synthase $(S c S u S y)$. . . . . . . . . . . . 75

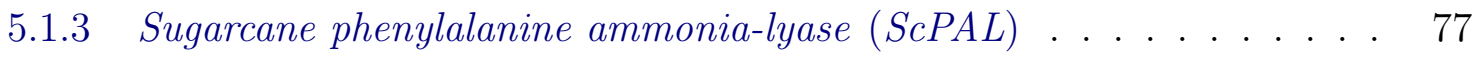

5.2 Análise da região Promotora de genes co-expressos . . . . . . . . . . . . . 78

5.3 TSSFinder - preditor ab initio do sinal de TSS em eucariotos . . . . . . . . 78

6 Conclusão $\quad 83$

A Material Suplementar $\quad \mathbf{8 5}$

A.0.1 Material e Métodos . . . . . . . . . . . . . . . . 85

A.0.2 RNA-Seq de cana-de-açúcar suplementar . . . . . . . . . . . 85

A.0.3 TSSFinder: desempenho em diferentes organismos superiores . . . . . 85

Referências Bibliográficas 


\title{
Lista de Abreviaturas
}

\author{
ABA Ácido Abscísico (Abscisic Acid) \\ BAC Cromossomos Artificiais de Bactéria (Bacterial Artificial Chromosome) \\ CDPK calcium-dependent protein kinase \\ CIPK CBL interacting serine/threonine-protein kinase \\ CRF Campos Aleatórios Condicionais (Conditional Random Fields) \\ CRM Módulos de Elementos Regulatórios em cis (Cis-Regulatory Module) \\ EST Etiquetas de Sequencias Expressas (Expressed Sequence Tag) \\ ERF Fator de Transcrição Responsivo a Etileno (ethylene-responsive transcription factor) \\ GEE Gases Efeito Estufa \\ GHMM Modelo Oculto de Markov Generalizado (Generalized Hidden Markov Model) \\ HD-ZIP homeobox-leucine zipper protein \\ HLH basic helix-loop-helix DNA-binding superfamily protein \\ HMM Cadeias ocultas de Markov (Hidden Markov Model) \\ JASPAR Banco de dados com PWMs anotadas \\ LC-CRF Cadeias Lineares-CRF (Linear-Chain CRF) \\ LBFGS (Limited-memory Broyden-Fletcher-Goldfarb-Shanno) \\ MC Cadeia de Markov (Markov Chain) \\ MEME Multiple EM for Motif Elicitation \\ nt nucleotídeos (nucleotideo)
}


ORF Sequência com Região Codificante (Open Reading Frame)

PAL phenylalanine ammonia-lyase

PP2C Proteína Fosfatase da Família 2c (Protein phosphatase 2C)

PSSM Matriz de Pontuações Específicas por Posição (Position-Specific Score Matrix)

PWM Matriz de Pesos por Posição (Position Weight Matrix)

TFBS Sítio de Ligação para Fatores de Transcrição (Transcription Factor Binding Site)

TF Fator de Transcrição (Transcription Factor)

TOMTOM Motif Comparison Tool

ToPS Toolkit for Probabilistic Models of Sequence

SAS Sugarcane Assembled Sequences

Scdr1 sugarcane drought-responsive 1

SnRK2 SNF1-related kinase

SUCAMET Sugarcane Metabolism Catalogue

SUCAST Sugarcane Signal Transduction Catalogue

SUCEST SugarCane EST Genome Project

SuSy sucrose synthase

$\mathrm{SR}(\mathrm{s}) \quad$ Sequências Regulatórias

SVM Support Vector Machines 


\section{Lista de Figuras}

1.1 Modelo de produção realizado em cana-de-açúcar . . . . . . . . . . . . . . . 2

1.2 Redução de emissões de Gases Efeito Estufa (GEE) através da comparação do consumo de Etanol em relação à Gasolina . . . . . . . . . . . . . . . . 3

1.3 Ranking mundial e brasileiro de commodities e produtos agrícolas . . . . . . 5

1.4 Representação esquemática da Região promotora TATA-box para organismos

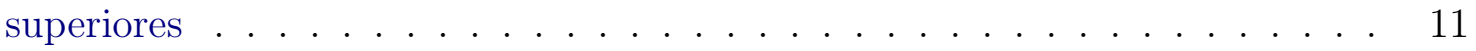

1.5 Representação gráfica do modelo TFFM . . . . . . . . . . . . . . . 25

1.6 Representação gráfica do modelo de HMM . . . . . . . . . . . . . . . . . . . 26

2.1 Esquema para caracterização da região da promotora através do transcriptoma. 28

2.2 Esquema de análise da região promotora para os genes co-expressos. . . . . . 31

2.3 Fluxograma para caracterização da região Core Promoter. . . . . . . . . . . . 33

2.4 Fluxograma para caracterização da região Promotora Proximal . . . . . . . . . 34

2.5 Máquina de estados representado as características da modelagem utilizada pelo TSSFinder para o problema de identificação do sinal de TSS . . . . . 35

2.6 Fluxograma de trabalho para predição do sinal de TSS . . . . . . . . . . . . 38

4.1 Região Promotora dos genes $S c S d r 1 \ldots \ldots$. . . . . . . . . . 43

4.2 Caracterização da região Promotora dos genes $S c S u S y$. . . . . . . . . . 56

4.3 Caracterização da região Promotora dos genes ScPAL . . . . . . . . . . . 57

4.4 Dados de expressão do transcriptomas de cana-de-açúcar SP80-3280 sob estresse hídrico f . . . . . . . . . . . . . . . . . . . . . . . . 58

4.5 Expressão gênica de sequências homeólogas do gene $S c d r 1$ no transcriptoma de SP80-3280. . . . . . . . . . . . . . . . . . . . . . 59

4.6 Genes co-expressos com gene Scdr1 no transcriptoma de SP80-3280 . . . . . . 59

4.7 Expressão da família gênica $S c S u S y 1$ no transcriptoma de SP80-3280 . . . . . 60

4.8 Genes co-expressos com gene ScSuSy1 no transcriptoma de SP80-3280. . . . 60

4.9 Expressão da família gênica ScSuSy2 no transcriptoma de SP80-3280. . . . . 61

4.10 Genes co-expressos com gene ScSuSy2 no transcriptoma de SP80-3280. . . . 61

4.11 Expressão da família gênica ScSuSy3 no transcriptoma de SP80-3280 . . . 62

4.12 Genes co-expressos com gene ScSuSy3 no transcriptoma de SP80-3280. . . . 62

4.13 Expressão da família gênica ScSuSy4 no transcriptoma de SP80-3280 . . . . . 63 
4.14 Genes co-expressos com gene ScSuSy4 no transcriptoma de SP80-3280. . . . 63

4.15 Expressão da família gênica ScSuSy5 no transcriptoma de SP80-3280. . . . . 64

4.16 Genes co-expressos com gene ScSuSy5 no transcriptoma de SP80-3280. . . . 64

4.17 Expressão da família gênica $S c P A L 1$ no transcriptoma de SP80-3280. . . . . 65

4.18 Genes co-expressos com gene ScPAL1 no transcriptoma de SP80-3280. . . . 65

4.19 Expressão da família gênica ScPAL2 no transcriptoma de SP80-3280. . . . . 66

4.20 Genes co-expressos com gene ScPAL2 no transcriptoma de SP80-3280. . . . 66

4.21 Expressão da família gênica ScPAL3 no transcriptoma de SP80-3280. . . . . 67

4.22 Genes co-expressos com gene ScPAL3 no transcriptoma de SP80-3280. . . . 67

4.23 Expressão da família gênica $S c P A L 4$ no transcriptoma de SP80-3280. . . . . 68

4.24 Genes co-expressos com gene ScPAL4 no transcriptoma de SP80-3280. . . . 68

4.25 Expressão da família gênica $S c P A L 5$ no transcriptoma de SP80-3280. . . . . 69

4.26 Genes co-expressos com gene ScPAL5 no transcriptoma de SP80-3280. . . . 69

4.27 Histograma de predição do TSSFinder para diferentes organismos . . . . . . 70

4.28 Histograma de predição de TSS nas ferramentas TIPR, TSSPlant e TSSFinder 71

A.1 Expressão da família gênica $S c S u S y 1$ no transcriptoma de cana-de-açúcar. 86

A.2 Genes co-expressos com gene ScSuSy1 no transcriptoma de cana-de-açúcar. . 86

A.3 Expressão da família gênica $S c S u S y 2$ no transcriptoma de cana-de-açúcar. $\quad 87$

A.4 Genes co-expressos com gene ScSuSy2 no transcriptoma de cana-de-açúcar. . 87

A.5 Expressão da família gênica $S c S u S y 3$ no transcriptoma de cana-de-açúcar . . 88

A.6 Genes co-expressos com gene ScSuSy3 no transcriptoma de cana-de-açúcar. . 88

A.7 Expressão da família gênica $S c S u S y 4$ no transcriptoma de cana-de-açúcar. $\quad$. 89

A.8 Genes co-expressos com gene ScSuSy4 no transcriptoma de cana-de-açúcar. . 89

A.9 Genes co-expressos com gene ScSuSy5 no transcriptoma de cana-de-açúcar. . 90

A.10 Expressão da família gênica $S c P A L 1$ no transcriptoma de cana-de-açúcar. . . 90

A.11 Genes co-expressos com gene ScPAL1 no transcriptoma de cana-de-açúcar. . 91

A.12 Expressão da família gênica $S c P A L 2$ no transcriptoma de cana-de-açúcar. . . 91

A.13 Genes co-expressos com gene ScPAL2 no transcriptoma de cana-de-açúcar. . 92

A.14 Expressão da família gênica $S c P A L 3$ no transcriptoma de cana-de-açúcar. . . 92

A.15 Genes co-expressos com gene ScPAL3 no transcriptoma de cana-de-açúcar. . 93

A.16 Expressão da família gênica $S c P A L 4$ no transcriptoma de cana-de-açúcar. . . 93

A.17 Genes co-expressos com gene ScPAL4 no transcriptoma de cana-de-açúcar. . 94

A.18 Expressão da família gênica $S c P A L 5$ no transcriptoma de cana-de-açúcar. . . 94

A.19 Genes co-expressos com gene ScPAL5 no transcriptoma de cana-de-açúcar. . 95

A.20 Expressão da família gênica $S c S u S y 1$ no transcriptoma de cana-de-açúcar. $\quad 95$

A.21 Genes co-expressos com gene ScSuSy1 no transcriptoma de cana-de-açúcar. . 96

A.22 Expressão da família gênica $S c S u S y 2$ no transcriptoma de cana-de-açúcar. 96

A.23 Genes co-expressos com gene ScSuSy2 no transcriptoma de cana-de-açúcar. . 97

A.24 Expressão da família gênica $S c S u S y 3$ no transcriptoma de cana-de-açúcar . . 97 
A.25 Genes co-expressos com gene $S c S u S y 3$ no transcriptoma de cana-de-açúcar. . 98 A.26 Expressão da família gênica $S c S u S y 4$ no transcriptoma de cana-de-açúcar. 98 A.27 Genes co-expressos com gene ScSuSy4 no transcriptoma de cana-de-açúcar. . 99 A.28 Expressão da família gênica $S c S u S y 5$ no transcriptoma de cana-de-açúcar. 99 A.29 Genes co-expressos com gene ScSuSy5 no transcriptoma de cana-de-açúcar. . 100 A.30 Expressão da família gênica $S c P A L 1$ no transcriptoma de cana-de-açúcar. . . 100 A.31 Genes co-expressos com gene $S c P A L 1$ no transcriptoma de cana-de-açúcar. . 101 A.32 Expressão da família gênica ScPAL2 no transcriptoma de cana-de-açúcar. . . 101 A.33 Genes co-expressos com gene ScPAL2 no transcriptoma de cana-de-açúcar. . 102 A.34 Expressão da família gênica $S c P A L 3$ no transcriptoma de cana-de-açúcar. . . 102 A.35 Genes co-expressos com gene ScPAL3 no transcriptoma de cana-de-açúcar. . 103 A.36 Expressão da família gênica $S c P A L 4$ no transcriptoma de cana-de-açúcar. . . 103 A.37 Genes co-expressos com gene ScPAL4 no transcriptoma de cana-de-açúcar. . 104 A.38 Expressão da família gênica $S c P A L 5$ no transcriptoma de cana-de-açúcar. . . 104 A.39 Genes co-expressos com gene ScPAL5 no transcriptoma de cana-de-açúcar. . 105 


\section{Lista de Tabelas}

1.1 Produção de cana-de-açúcar nas principais regiões produtoras do Brasil ${ }^{1}$. . 5

2.1 Quadro de informações para a seleção de genes co-expressos e sequências de

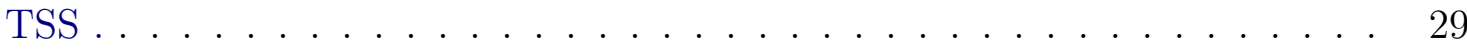

2.2 Total de sequências de DNA da região promotora em diferentes organismos com localização do sinal de TSS validado por experimentos biológicos ${ }^{2}$. . . . 32

4.1 Resultado da predição de novo de TFBS na familia de genes ScSuSy. . . . . 45

4.2 Resultado da predição de novo de TFBS na família de genes $S c P A L$. . . . . 47

4.3 Resultado de predição do TSSFinder para o sinal de TSS em diferentes orga$\operatorname{nismos}^{3} \ldots \ldots \ldots \ldots \ldots \ldots \ldots$

4.4 Tempo médio de execução da ferramenta TSSFinder durante o treinamento . 52

4.5 Tempo médio de execução da ferramenta TSSFinder durante a predição . . . 52

4.6 Desempenho do modelo TSSFinder contra outras ferramentas . . . . . . . . 53

4.7 Tempo de execução do processo de predição nas ferramentas TSSFinder, TSSPlant e TIPR . . . . . . . . . . . . . . . . . 54

4.8 Resultado de predição do TSSFinder para diferentes conjuntos de treinamento 55

A.1 Representação em HMM do problema da moeda desonesta . . . . . . . . . . 85

A.2 Representação em LCCRF do problema da moeda desonesta . . . . . . . . . 85

A.3 Duração do processo de predição do TSSFinder em diferentes organismos . . 106

A.4 Duração do processo de treinamento do TSSFinder em diferentes organismos 107

A.5 Resultado de predição do TSSFinder em A.thaliana considerando diferentes janelas de nucleotídeos . . . . . . . . . . . . . . . . . . . . . . . 108

A.6 Resultado de predição do TSSFinder em D. melanogaster considerando diferentes janelas de nucleotídeos . . . . . . . . . . . . . . . . 109

A.7 Resultado de predição do TSSFinder em S. cerevisiae considerando diferentes janelas de nucleotídeos . . . . . . . . . . . . . . . . . . . 110 


\section{Capítulo 1}

\section{Introdução}

\subsection{Cana-de-açúcar}

\subsubsection{Histórico}

Desde o descobrimento do Brasil a atividade econômica predominante no país é fortemente associada com o setor agrícola. De fato o setor sucroalcooleiro apresentou grande impacto no desenvolvimento da economia e da indústria local naquela época. A principal motivação para o cultivo de cana-de-açúcar em terras brasileiras estava diretamente atrelada ao comércio internacional de açúcar entre os séculos XV e XVI [Cheavegatti-Gianotto et al., 2011, Dinardo-Miranda et al., 2008, UNICA, 2018].

Nesse momento da história, apesar das limitações, o Brasil colônia experimentou algum desenvolvimento econômico e esse desenvolvimento se deu através da elevada capitalização do açúcar no mercado internacional - em especial o mercado europeu - e a construção e manutenção dos engenhos de cana-de-açúcar em áreas de produção agrícola [Dinardo-Miranda et al., 2008, UNICA, 2018]. Este modelo de produção desenvolvido no início da colonização é seguido até hoje, onde grande parte do cultivo de cana-de-açúcar é realizado pela própria Usina [CONAB, 2018, UNICA, 2018]. A figura 1.1 apresenta o esquema para produção e processamento de cana-de-açúcar no Brasil.

Apesar da importância histórica do cultivo de cana-de-açúcar para o Brasil colônia, a produção de cana-de-açúcar foi frequentemente colocada em segundo plano nos anos seguintes [UNICA, 2018]. No entanto, durante a crise do petróleo na década de 70, o potencial econômico do cultivo de cana-de-açúcar foi evocado mais uma vez para ancorar os setores comerciais e industriais do País [Cheavegatti-Gianotto et al., 2011, Dinardo-Miranda et al., 2008, UNICA, 2018]. Nesse período o cultivo de cana-de-açúcar foi responsável pela redução da dependência do petróleo através do desenvolvimeno do mercado de biocombustível (Etanol) [Dinardo-Miranda et al., 2008, UNICA, 2018]. Durante essa época o Brasil esteve na vanguarda do desenvolvimento sustentável. Com o projeto Proálcool o Brasil conseguiu substituir aproximadamente $90 \%$ da frota de carros leves movidos a gasolina para carros movidos a Etanol. Entretanto, quando o mercado de petróleo recuperou-se da crise iniciada 


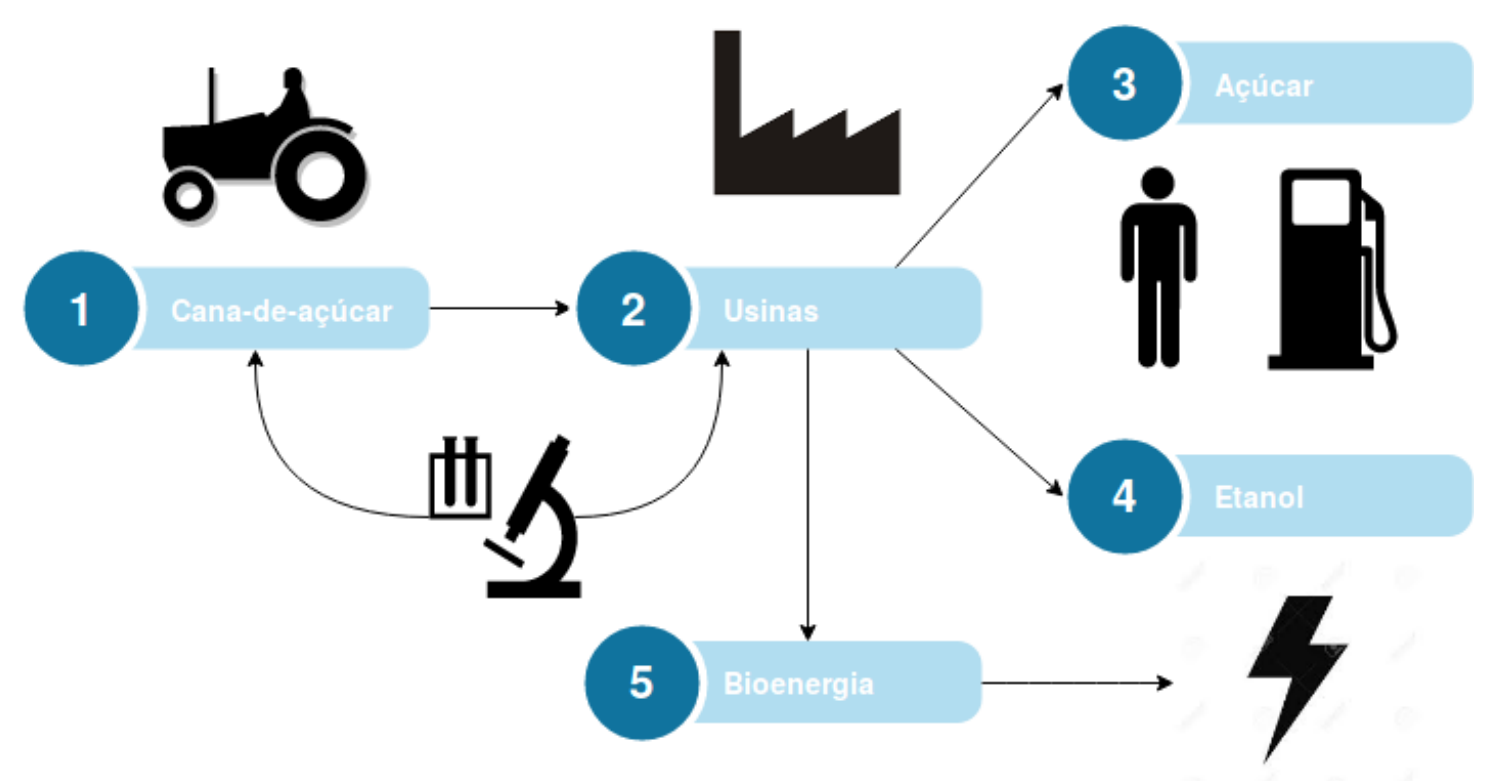

Figura 1.1: Modelo de produção realizado em cana-de-açúcar O círculo 1 representa a produção agrícola. O círculo 2 representa a indústria sucroalcooleira. Os círculos 3,4 e 5 representam os principais produtos gerados a partir do cultivo da cana-de-açúcar: Açúcar, Etanol e Bioenergia.

nos anos 70, a produção de biocombustível foi desestimulada e o setor entrou em declínio [Dinardo-Miranda et al., 2008, UNICA, 2018].

Desde o início do século XIX, a consciência ambiental mundial está em evidência e essa tendência tem tornado o uso de energia renovável uma atividade imperiosa para todos os setores econômicos [de Siqueira Ferreira et al., 2013, Souza et al., 2015]. Neste cenário, o cultivo de cana-de-açúcar tem conquistado novamente o seu protagonismo de cultura economicamente sustentável [Souza et al., 2015]. Essa característica da cana-de-açúcar é devida a sua flexibilidade sócio-ambiental uma vez que a produção de alimento (açúcar), a produção de energia (Biomassa) e de biocombustível (Etanol) não apresentam conflitos diretos como é possível observar em outras culturas como milho, trigo e beterraba [de Siqueira Ferreira et al., 2013, Souza et al., 2015, UNICA, 2018]. Nessa nova fase a canade-açúcar não é vista apenas como produtora de alimento ou de Etanol e sim como uma matriz energética sustentável capaz de amenizar ou remediar a emissão de gases do efeito estufa (GEE) que são em parte responsáveis pelo aquecimento global e pelas mudanças climáticas [de Siqueira Ferreira et al., 2013, Souza et al., 2015].

A figura 1.2 apresenta o balanço energético do cultivo de cana-de-açúcar para produção de Etanol. Na primeira parte da figura 1.2 é apresentado o balanço de emissões GEE do Etanol produzido pela cana-de-açúcar desde cultivo até o consumo final de Etanol. Na segunda parte da figura 1.2 é apresentado uma estimativa da redução da emissão de GEE do Etanol em relação a Gasolina. A estimativa foi realizada considerando diferentes plantas para produção de Etanol [UNICA, 2018]. 


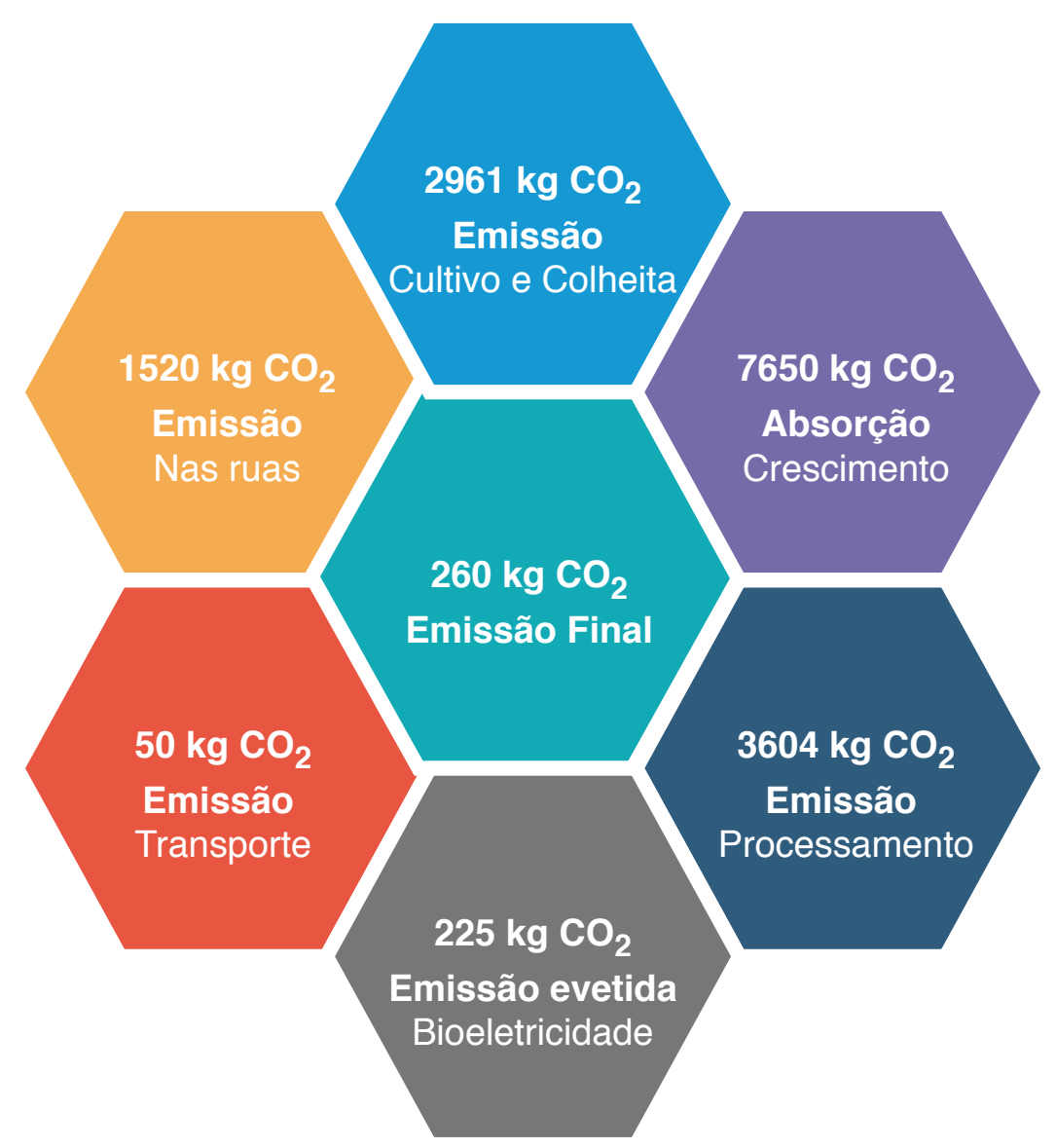

a)

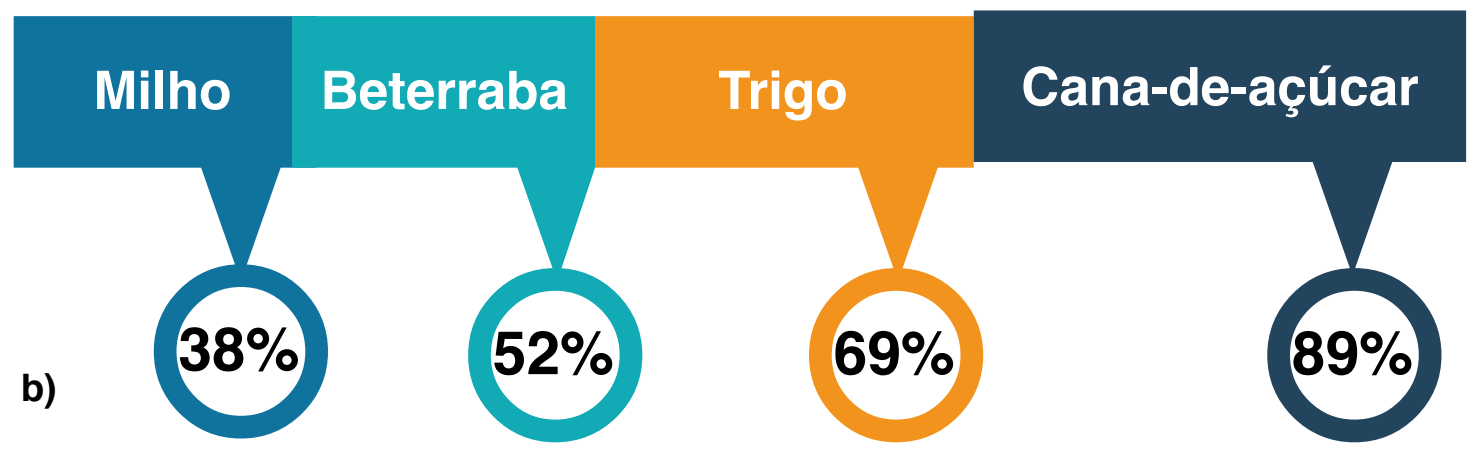

Figura 1.2: Redução de emissões de Gases Efeito Estufa (GEE) através da comparação do consumo de Etanol em relação à Gasolina

a) Balanço de emissões de GEE em relação a produção e o consumo de Etanol produzido a partir de cana-de-açúcar. b) Balanço de emissões de GEE para o consumo de Etanol produzido a partir de diferentes plantas. (adaptado de http://www.unica.com.br/linhadotempo).

\subsubsection{Caráter Botânico e Genético}

A cana-de-açúcar (Saccharum spp) é uma planta da família Poaceae assim como outras plantas de valor comercial tais como milho, arroz e sorgo [Cheavegatti-Gianotto et al., 2011, Thirugnanasambandam et al., 2018]. As plantas de cana-de-açúcar apresentam inflorescência em forma de espiga, o caule em colmos e as folhas com bordas e bainha aberta [Dinardo-Miranda et al., 2008]. O gênero Saccharum - açúcar em Latim - foi descrito primeiramente por Linnaeus, em 1753 no seu livro Species Plantarum com duas espécies descritas 
inicialmente: Saccharum officinarum L. e S. spicatum L.; entretanto a última espécie foi revista para o gênero Perotis [Cheavegatti-Gianotto et al., 2011]. Além da espécie S. officinarum outras plantas foram descritas no gênero Saccharum: S. spontaneum, S. sinense, S. edule e $S$. barberi. Ademais, para diferentes autores, o local mais provável para o centro de origem do gênero Saccharum é o sudeste Asiático [Cheavegatti-Gianotto et al., 2011, de Siqueira Ferreira et al., 2013, Thirugnanasambandam et al., 2018].

As espécies do gênero Saccharum apresentam elevado nível de ploidia e as plantas mais recentes desse gênero são consideradas alopoliplóides e aneuplóides [Souza et al., 2011, Vilela et al., 2017]. Essa mudança ocorreu durante o processo de domesticação da cana-deaçúcar principalmente através da hibridização entre as espécies S. officinarum e S. spontaneum [Dinardo-Miranda et al., 2008, Thirugnanasambandam et al., 2018]. Estudos anteriores que avaliaram a hibridação in situ de plantas cana-de-açúcar geradas pelo cruzamento das espécies S. officinarum e S. spontaneum têm apresentado que o genoma dos híbridos é composto de aproximadamente $20 \%$ de cromossomos de S. spontaneum, $5 \%$ de cromossomos recombinantes entre S.officinarum e S. spontaneum e o restante composto por cromossomos de S. officinarum [Cheavegatti-Gianotto et al., 2011, Souza et al., 2011, Thirugnanasambandam et al., 2018]. A principal razão para a hibridação de plantas canade-açúcar está baseada nas características agronômicas que as espécies apresentavam: $S$. officinarum - maior acúmulo de sacarose no colmo - e S. spontaneum - resistência a doenças e ao estresse abiótico [Cheavegatti-Gianotto et al., 2011, Dinardo-Miranda et al., 2008]. Devido a amplitude do cultivo de cana-de-açúcar em todas as regiões tropicais e subtropicais do mundo, a produção de cana-de-açúcar foi distribuída no globo desde os primeiros anos de domesticação. Hoje os principais produtos gerados pelo seu cultivo da cana-de-açúcar são açúcar e Etanol [Cheavegatti-Gianotto et al., 2011, Dinardo-Miranda et al., 2008].

\subsubsection{Caráter Econômico}

Na safra 2018/19 o Brasil estima produzir 625,96 milhões de toneladas de cana-de-açúcar. De acordo com esse levantamento a produção de cana-de-açúcar terá redução de 1,2\% em relação à safra anterior [CONAB, 2018]. Essa tendência também é esperada para a área total colhida tabela 1.1. Estima-se que a área para produção de cana-de-açúcar fique próxima a 8,61 milhões de hectares, esse valor representa uma queda de 1,3\% em relação a safra anterior (2017/18). Além disso o levantamento da CONAB aponta para uma redução na produção de açúcar em 6,3\% e um leve incremento de 1,4\% na produção de Etanol. Da produção total de Etanol espera-se que o Etanol anidro aumente 7\% e que Etanol hidratado reduza 2,3\%. De acordo com o estudo da CONAB [2018] a principal influência na configuração deste cenário está associada a dois fatores: aumento do consumo de gasolina nos últimos anos e oscilação negativa do preço mundial do açúcar [CONAB, 2018]. Apesar da estimativa negativa feita pela CONAB [2018], o Brasil ainda manterá o protagonismo de maior produtor de canade-açúcar do mundo. Consequentemente, a exportação tanto de açúcar bruto quanto de 
açúcar refinado será mantida e o Brasil ainda seguirá na ponteira do ranking mundial para exportação de açúcar [CONAB, 2018, FAOstat, 2018].

Tabela 1.1: Produção de cana-de-açúcar nas principais regiões produtoras do Brasil ${ }^{1}$

\begin{tabular}{lllllllll}
\hline & & & & & & & \\
& $2011 / 12$ & $2012 / 13$ & $2013 / 14$ & $2014 / 15$ & $2015 / 16$ & $2016 / 17$ & $2017 / 18$ & $2018 / 19$ \\
\hline & & & & & & & & \\
NORTE/NORDESTE & $1,149.10$ & $1,125.20$ & $1,076.60$ & $1,026.60$ & 967.9 & 918.8 & 891.7 & 893.8 \\
SP & $4,370.10$ & $4,419.50$ & $4,552.00$ & $4,685.70$ & $4,498.30$ & $4,773.20$ & $4,558.40$ & $4,439.80$ \\
CENTRO-SUL & $7,213.50$ & $7,359.80$ & $7,734.80$ & $7,977.90$ & $7,686.90$ & $8,130.40$ & $7,837.80$ & $7,719.80$ \\
BRASIL & $8,362.60$ & $8,485.00$ & $8,811.40$ & $9,004.50$ & $8,654.80$ & $9,049.20$ & $8,729.50$ & $8,613.60$ \\
\hline
\end{tabular}

Na figura 1.3 é possível perceber a importância da cana-de-açúcar para economia mundial. Ela ocupa a quinta posição no ranking de culturas mais exportadas no mundo (d). Considerando a produção mundial de cana-de-açúcar, o Brasil responde a quase $50 \%$ da produção total (b). Além disso, no cenário nacional a cana-de-açúcar sobe para primeira posição no ranking de produção (a) e terceira posição no ranking exportação (c) [FAOstat, 2018].
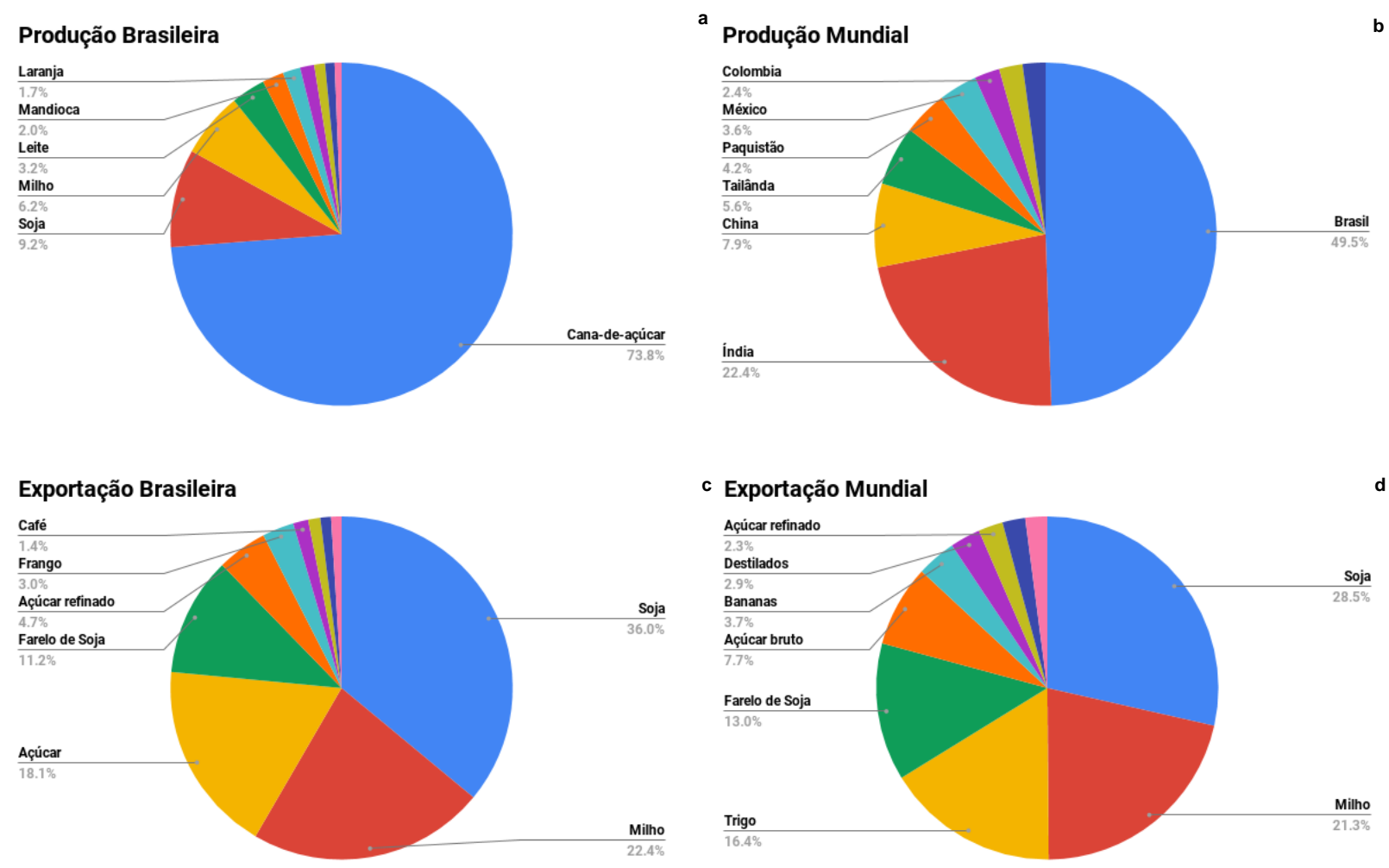

Figura 1.3: Ranking mundial e brasileiro de commodities e produtos agrícolas

a) Produção brasileira de commodities. b) Produção Mundial de cana-de-açúcar. c) Exportação brasileira de commodities e produtos agrícolas. d) Exportação Mundial de commodities e produtos agrícolas. Adaptado FAO [FAOstat, 2018].

\footnotetext{
${ }^{1}$ Os valores para Safra 2018/19 é uma estimativa da CONAB [2018].
} 


\subsubsection{Sequências de DNA de cana-de-açúcar}

A poliploidia é apontado como um dos fatores mais importantes para obtenção de novas redes de regulação gênica seja esta através da duplicação de genes ou através da geração de novas funcionalidades gênicas [Cheavegatti-Gianotto et al., 2011, Thirugnanasambandam et al., 2018, Vilela et al., 2017]. Além do processo de poliploidia, outro fator que pode contribuir com a flexibilidade genética de plantas Poliplóides está no cruzamento destas espécies. Com esse mecanismo, a diversidade genética pode ser gerada através do cruzamento de plantas da mesma espécie (plantas autopoliplóides) ou entre espécies diferentes (plantas alopoliplóides) [Thirugnanasambandam et al., 2018, Vilela et al., 2017].

De acordo com a literatura, todas cultivares modernas de cana-de-açúcar são plantas híbridas do cruzamento interespecífico de S. officinarum e S. spontaneum [Souza et al., 2011, Vilela et al., 2017]. Ademais, acredita-se que estes mesmos progenitores são originários de processos de auto-poliploidização, consequentemente, as cultivares modernas de cana-deaçúcar apresentam elevado grau de poliploidia e aneuploidia [Cheavegatti-Gianotto et al., 2011, De Setta et al., 2014, Thirugnanasambandam et al., 2018, Vilela et al., 2017]. Por estas características até momento não há nenhum genoma de referência para cana-de-açúcar [Souza et al., 2011, Thirugnanasambandam et al., 2018].

O Projeto SUCEST (SugarCane EST Genome Project - SUCEST) é o principal catálogo de sequências expressas (Expressed Sequences Tags - EST) para cana-de-açúcar e esta iniciativa tem contribuído ativamente para o conhecimento genético de cana-de-açúcar nos últimos anos [Ferreira et al., 2016, Hotta et al., 2013, Nishiyama et al., 2010, Papini-Terzi et al., 2009, Vettore et al., 2003]. A partir de diferentes bibliotecas de cDNA, o projeto SUCEST conseguiu reunir mais de 230 mil ESTs de cana-de-açúcar em diferentes condições. No projeto SUCEST mais 43.141 SAS (SAS - Sugarcane Assembled Sequences) foram geradas e com esta informação foi possível expandir o conhecimento relacionado com o transcriptoma de cana-de-açúcar [Nishiyama et al., 2010] em diferentes setores tais como: teor de sacarose, produção de lignina e respostas a estímulos bióticos ou abióticos [Ferreira et al., 2016, Hotta et al., 2013, Nishiyama et al., 2010, Papini-Terzi et al., 2009, Vettore et al., 2003].

Todo esse conhecimento foi organizado em cinco catálogos. O primeiro catálogo foi associado com a via de transdução de sinal (Sugarcane Signal Transduction Catalogue - SUCAST), o segundo com vias metabólicas (Sugarcane Metabolism Catalogue - SUCAMET), o terceiro com o metabolismo da parede celular (Sugarcane Cell Wall Catalogue), o quarto associado com fatores de transcrição (Sugarcane Transcription Factor Catalogue) e o último com elementos transponíveis (Sugarcane Transposable Elements Catalogue) [Ferreira et al., 2016, Nishiyama et al., 2010]. Tanto o conjunto total de ESTs quanto os catálogos foram reunidos no banco de dados SUCEST-FUN e estão disponíveis via web para toda comunidade científica [Nishiyama et al., 2010, Vettore et al., 2003]. Apesar da contribuição do SUCEST-FUN, o genoma de referência para cana-de-açúcar é ainda fundamental para ampliar o conhecimento dessa cultura assim como promover o melhoramento genético mais 
eficiente [de Siqueira Ferreira et al., 2013, Souza et al., 2011, Thirugnanasambandam et al., 2018].

O conhecimento anterior sobre a cana-de-açúcar mais o avanço na tecnologia de sequenciamento de DNA podem contribuir para o desenvolvimento do genoma de referência para plantas de cana-de-açúcar [Souza et al., 2011, Thirugnanasambandam et al., 2018]. Entretanto, a principal estratégia de sequenciamento do genoma de cana-de-açúcar está baseada em BACs [De Setta et al., 2014, Thirugnanasambandam et al., 2018]. Infelizmente essa metodologia tem apresentado montagem de genomas com baixa cobertura e este cenário é ainda pior quando a comparação é realizada com outras culturas que já utilizaram essa mesma metodologia [Thirugnanasambandam et al., 2018]. Em geral, se considerarmos o genoma com tamanho aproximado de 10G, o sequenciamento do genoma monoplóide de cana-de-açúcar apresenta cobertura de 14x (14 vezes) e quando a estimativa é atribuída ao genoma poliplóide essa cobertura cai para 1,3x. A principal justificativa para estes números está na complexidade do genoma de cana-de-açúcar uma vez que o grau de ploidia e o número de regiões repetitivas é elevado [De Setta et al., 2014, Thirugnanasambandam et al., 2018, Vilela et al., 2017].

Apesar dessa dificuldade, há uma iniciativa internacional para o sequenciamento do genoma de referência de cana-de-açúcar. Este projeto é liderado pelo grupo SUGESI (Sugarcane Genome Sequencing initiative - SUGESI), no entanto, até momento apenas informações pontuais sobre o genoma de cana-de-açúcar estão disponíveis. Desse empreendimento é possível encontrar dados oriundos do Transcriptoma (RNA-Seq de novo) para diferentes variedades de cana-de-açúcar [Cardoso-Silva et al., 2014, Li et al., 2016, Vicentini et al., 2015], ORFome de cana-de-açúcar (S. officinarum, S. spontaneum e SP80-3280) [Nishiyama et al., 2014], genoma monoplóide de R570 [De Setta et al., 2014] e o rascunho do genoma de cultivares híbridas [Thirugnanasambandam et al., 2018].

\subsection{Regulação Gênica}

O desenvolvimento e crescimento dos organismos superiores é realizado em diferentes etapas. Durante esse processo de transformação diferentes tipos de células são formados e cada tipo celular apresenta uma função específica [Spitz and Furlong, 2012, Villar et al., 2014, Watson et al., 2015]. Toda essa diversidade tem sua origem a partir da informação codificada dentro do genoma dos organismos e essa informação é uniforme para todas células do organismo. A hipótese mais provável para origem dessa diversidade está na regulação gênica uma vez que este é o principal mecanismo utilizado pelo organismo para acessar e executar todas as informações codificadas no genoma [Levo and Segal, 2014, Villar et al., 2014, Watson et al., 2015].

O processo de regulação gênica pode ser dividido em diferentes etapas que envolvem desde a acessibilidade do DNA genômico até o processamento pós transcricional do gene [Ladunga, 
2010, Levo and Segal, 2014, Villar et al., 2014]. Entre estes mecanismos podemos destacar os realizados pelos Fatores de Transcrição (Transcription Factor - TF), a remodelagem do Nucleossoma, a ação de microRNAs, as alterações químicas na estrutura das Histonas e por fim a região Promotora [de los Reyes et al., 2015, Holoch and Moazed, 2015, Keung et al., 2015, Watson et al., 2015].

Neste trabalho, a análise do processo de regulação gênica será direcionado apenas para o reconhecimento da região Promotora assim como a identificação dos sítios de ligação para os Fatores de Transcrição (Transcription Factor Binding Site - TFBS), ambos localizados na sequência de DNA não codificante upstream dos genes preditos em cana-de-açúcar SP803280. Nas seções seguintes apresentamos uma breve introdução sobre a região Promotora e os Fatores de Transcrição, além de alguns exemplos da importância destes dois mecanismos para o processo de regulação gênica.

\subsubsection{Fatores de Transcrição}

Os TFs são proteínas que apresentam atividade regulatória no momento da transcrição gênica e esta atividade é executada principalmente pelo processo de interação proteína-DNA [Levo and Segal, 2014, Watson et al., 2015]. A ação destas proteínas pode ocorrer tanto no momento inicial da transcrição - através dos TFs gerais - quanto no período mais tardio da transcrição - através de TFs que apresentam a classificação de Inibidores ou Potenciadores da transcrição [Levo and Segal, 2014, Shlyueva et al., 2014, Spitz and Furlong, 2012]. No geral, o principal objetivo dos TFs é controlar a transcrição de genes [Levo and Segal, 2014, Watson et al., 2015].

Os TFs têm dois domínios proteicos: i) Interação Proteína-DNA e ii) Ativação. A atividade regulatória dos TFs é exercida pela ação conjunta dos dois domínios. Basicamente, podemos considerar o domínio de Interação Proteína-DNA como o fator que determinará qual conjunto de sequências de DNA será regulado e o domínio de Ativação como o fator modulador da regulação gênica exercendo as funções de ativação, inibição ou potencialização da expressão gênica [Levo and Segal, 2014, Spitz and Furlong, 2012, Watson et al., 2015].

O processo de Interação Proteína-DNA é o principal mecanismo utilizado pelos TFs para regular especificamente a transcrição do mRNA. Através desse mecanismo os TFs podem interagir com qualquer região do genoma desde que nestas regiões o sítio de ligação esteja presente (subsequência de DNA) para interação com o TF. Para nosso trabalho, qualquer subsequência de DNA que apresentar capacidade de regular a expressão gênica será sinônimo de Sequências Regulatórias [Ladunga, 2010, Watson et al., 2015].

\subsubsection{Sequências Regulatórias}

O conjunto de subsequências de DNA com capacidade de realizar interação com proteínas reguladoras é denominado de Sequências Regulatórias (SRs). A principal função das SRs é ancorar na fita de DNA estas proteínas e direcionar a regulação transcricional de genes 
através do processo de ligação com o domínio proteico do TF (Interação Proteína-DNA). As SRs são formadas pelo conjunto de diferentes TFBSs localizados na região Promotora e nos Módulos de elementos regulatórios em cis (Cis-Regulatory Module - CRM) que podem ser denominados de Potenciadores, Inibidores ou Insuladores [Edwards et al., 2009, Ladunga, 2010, Watson et al., 2015]. As principais características das SRs incluem o tamanho dos TFBSs (os motivos apresentam sequência de DNA curta com tamanho variando entre 6 nt a 20 nt), a localização (os motivos estão localizados em diferentes regiões da sequência de DNA podendo estar próxima do gene alvo ou a milhares de nucleotídeos de distância do gene alvo), e a sequência consenso (degenerada - algumas posições da sequência consenso podem apresentar qualquer nucleotídeo) [Edwards et al., 2009, Ladunga, 2010]. Portanto, a identificação e a análise de SRs é uma tarefa complexa e desafiadora.

Para identificar as SRs é necessário realizar dois processos complementares. O primeiro processo é identificar o TFBS - ou seja, a subsequência de DNA - e o processo seguinte é determinar para cada TFBS conhecido qual coordenada genômica ele está localizado na sequência de DNA [Edwards et al., 2009, Ladunga, 2010]. Com isso, tanto o tamanho da sequência consenso quanto a localização genômica de cada TFBS poderá proporcionar inúmeros processos de interação TF-TFBS e por conseguinte diferentes mecanismos de regulação [Levo and Segal, 2014, Villar et al., 2014, Watson et al., 2015]. A identificação das SRs pode ser realizada pela via biológica através de técnicas como microarranjo de ligação para proteínas (Protein-Binding Microarray - PBM) e Imunoprecipitação da cromatina seguida de sequenciamento do DNA (Chromatin Immunoprecipitation Sequencing - ChIP-Seq) ou então através da análise in silico usando modelos matemáticos e algoritmos computacionais [Franco-Zorrilla and Solano, 2017, Ladunga, 2010].

Em 2014 Franco-Zorrilla et al. identificaram 65 TFs e seus respectivos TFBSs usando a técnica in vitro PBM. Neste trabalho os autores utilizaram a planta modelo Arabidopsis thaliana e eles observaram que aproximadamente metade dos TFs identificados apresentavam mais de um TFBS. Além disso, $80 \%$ dos TFBS (SRs) identificados foram confirmados através de dados do transcriptoma de genes co-regulados. Para todas SRs identificadas, a função do seu respectivo TF foi estimada através de análises in silico. De acordo com o trabalho, a identificação do TF a partir da predição da SR pode ser realizada com êxito, assim como a predição funcional que cada interação TF-TFBS pode exercer na região promotora [Franco-Zorrilla et al., 2014]. Apesar destes resultados, a análise experimental não é uma tarefa trivial e sua aplicação em outros organismo pode ser limitada. Dessa forma a análise in silico é o método para identificação de SRs mais universal uma vez que nesta metodologia a tarefa de rotulação da SR é realizada em qualquer organismo que tenha a sequência de DNA genômico disponível.

$\mathrm{Na}$ análise in silico a identificação de TFBSs pode ser realizada por até três metodologias [Edwards et al., 2009, Ladunga, 2010]. Na primeira metodologia a identificação dos TFBSs é realizada pela utilização de TFBSs já descritos na literatura. Com essa metodologia, a identificação do TFBS é direcionada para um grupo específico de SRs (em geral 
a região Promotora). Esse direcionamento é ideal para as análises onde há forte evidência biológica da ação de um determinado conjunto de TFBS [Edwards et al., 2009, Ladunga, 2010, Rombauts et al., 2003]. A segunda metodologia utiliza o mapeamento de sequências consenso de TFBSs conhecidos ou simplesmente através do mapeamento de diferentes kmers nas sequências de DNA. Neste processo de análise, a identificação dos TFBSs está fortemente associada a modelos matemáticos. Essa associação é necessária para assegurar que todos TFBSs observados na sequência alvo apresentem score maior que o modelo de background [Edwards et al., 2009, Ladunga, 2010, Rombauts et al., 2003]. A última metodologia é direcionada para descoberta de novo de TFBSs. Nessa metodologia o processo de análise é orientado por diferentes modelos probabilísticos e o procedimento de descoberta de TFBS é realizado com pouca ou nenhuma informação sobre as características do TFBS. Dessa forma a predição de TFBS através da metodologia de novo favorece a identificação de novos TFBSs ainda não descritos na literatura [Edwards et al., 2009, Ladunga, 2010, Rombauts et al., 2003].

Apesar do uso isolado de cada metodologia, alguns estudos têm indicado a utilização conjunta das três metodologias para gerar resultados mais satisfatórios [Edwards et al., 2009, Ladunga, 2010] e este será o paradigma utilizado no nosso trabalho.

\subsection{Região Promotora}

Em eucariotos superiores, o processo de transcrição do DNA - síntese de RNA mensageiro (mRNA) - pode ser realizado por três RNA polimerases distintas [Adelman and Lis, 2012]. Ademais em plantas essa função pode ser realizada por até cinco RNA polimerases [Watson et al., 2015]. Contudo, a transcrição de genes codificantes de proteínas é realizada somente pela RNA polimerase II (RNA pol II ) [Levo and Segal, 2014]. Dessa forma, toda descrição sobre região Promotora é direcionada para genes que são transcritos pela RNA pol II. Além disso o paradigma de região Promotora utilizado neste trabalho será de plantas superiores e ocasionalmente podemos usar exemplos descritos em metazoários ou fungos. Na figura 1.4 apresentamos o modelo geral da região Promotora TATA-box nos organismos superiores.

A região Promotora é uma sequência de DNA não codificante, localizada à montante de todos os genes e sua principal função é modular a expressão gênica [Levo and Segal, 2014, Spitz and Furlong, 2012, Watson et al., 2015]. O principal mecanismo de modulação exercido pela região promotora está na montagem do complexo transcricional. Na ausência do complexo transcricional a RNA pol II não poderá transcrever o mRNA da sequência de DNA codificante que fica à jusante da região Promotora. Além disso, qualquer erro durante a montagem do complexo transcricional influenciará diretamente a transcrição do gene [de los Reyes et al., 2015, Rombauts et al., 2003]. Portanto, a região Promotora pode determinar de forma direta a quantidade, o tipo e o período de produção dos transcritos 
[Mejía-Guerra et al., 2015, Yamamoto et al., 2009].

A sequência de DNA da região Promotora é caracterizada, de forma geral, como um conjunto de subsequências de DNA específicas para a ligação com os TFs Gerais [Adelman and Lis, 2012, Levo and Segal, 2014, Spitz and Furlong, 2012, Villar et al., 2014]. Estas proteínas são responsáveis pela montagem do complexo transcricional e por conseguinte pelo recrutamento da RNA polimerase. Todo esse mecanismo de montagem e recrutamento de TFs são fundamentais para o início da transcrição gênica. Além dos TFs e da RNA pol II, outro ponto fundamental para regulação gênica é a delimitação da sequência de DNA da região Promotora com a região gênica. Até o momento o sítio de início de transcrição (Transcription Start Site - TSS) tem sido apresentado como o principal sinal para determinar a fronteira entre estas regiões [Adelman and Lis, 2012, Mejía-Guerra et al., 2015, Shiraki et al., 2003]. Apesar dessa importância, o TSS é descrito na literatura com apenas dois nucleotídeos, com sequência degenerada e localização variável ao longo da sequência de DNA da região Promotora. Portanto, estas características tornam a delimitação da região Promotora uma tarefa não trivial [Dreos et al., 2016, Morton et al., 2015, Shahmuradov et al., 2017].
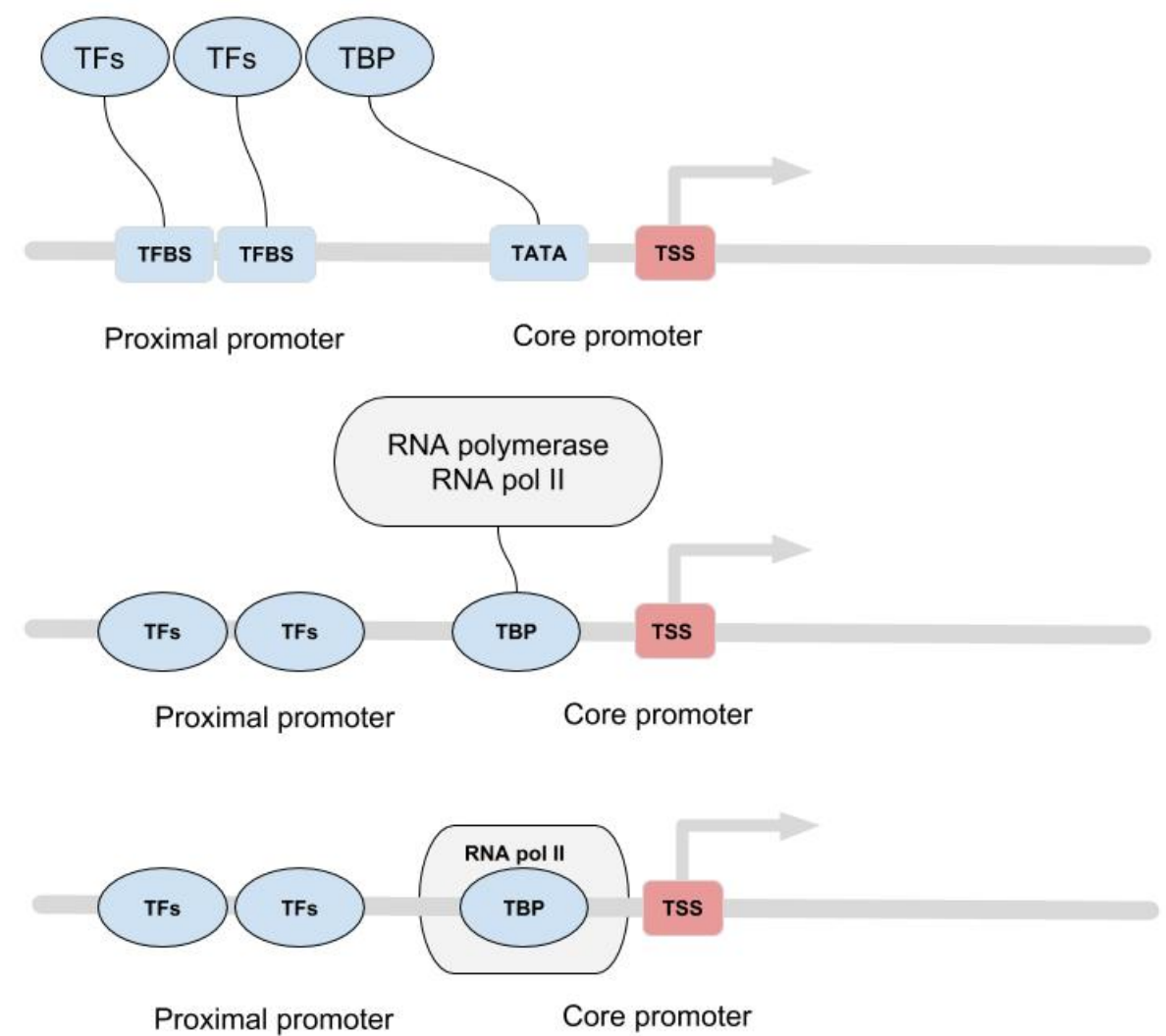

Figura 1.4: Representação esquemática da Região promotora TATA-box para organismos superiores O esquema é uma simplificação do processo de montagem do complexo transcricional. O sítio do TSS é representado pelo retângulo vermelho, os sítios de TFBSs são representados pelos retângulos azuis, as elipses representam as proteínas TFs e o retângulo arredondado representa a RNA pol II.

A capacidade da região Promotora de controlar a expressão de genes já é bem conhecida e 
nos últimos anos seus estudos foram realizados em diferentes organismos [Mejía-Guerra et al., 2015, Rombauts et al., 2003, Yamamoto et al., 2009]. Em Milho, Mejía-Guerra et al. [2015] observaram que a expressão diferencial de três genes em duas variedades de Milho era devido a região Promotora distinta nos três genes. De acordo com os autores esta diferença foi fundamental para influenciar a expressão dos três genes tanto na parte aérea quanto na parte radicular das plantas. Ademais, os autores estimaram que a capacidade de modulação observada foi ocasionada pelo mudança no posicionamento do TSS. Essa mudança na posição do TSS interfere na arquitetura da região Promotora permitindo assim refinar o processo de regulação ativando ou inativando os TFBSs localizados na sequência de DNA da região Promotora e com isso modular a quantidade e localização do mRNA transcrito [Mejía-Guerra et al., 2015]. Já em outro trabalho, usando Arabidopsis, Yamamoto et al. observaram que a presença dos TSSs agrupados numa única posição da sequência de DNA e a reunião de diferentes TFBSs tais como TATA-box, Inr e Y-patch são fundamentais para definir uma arquitetura de região Promotora com elevada capacidade de estimular a expressão gênica [Yamamoto et al., 2009]. Como ilustrado nos dois trabalhos, tanto a diferença de posicionamento do TSS quanto a concentração de diferentes TFBSs na região Promotora podem contribuir com a funcionalidade e especificidade destas sequências durante o processo transcricional [Mejía-Guerra et al., 2015, Yamamoto et al., 2009].

Em Kumari and Ware [2013] identificaram diferentes arquiteturas de TFBSs na região Promotora de plantas Monocotiledôneas e Dicotiledôneas. Os autores observaram que plantas Monocotiledôneas apresentam diferenças na região Promotora quanto a presença, a organização e a distribuição dos TFBSs em relação a plantas Dicotiledôneas. Neste trabalho, os autores usaram a abordagem in silico para avaliar a presença de 13 TFBSs [TATA-box, CCAAT-box, BREu, BREd, GC-box, DCE-S1, DCE-S2, DCE-S3, DPE, XCPE-1, MDE-1 e MTE] que são comumente encontrados na região Promotora de eucariotos superiores. De acordo com Kumari and Ware, foi possível determinar três classes para a região Promotora de plantas Monocotiledôneas e Dicotiledôneas: TATA (+), TATA (-) e CPE (-). A classe TATA $(+)$ foi mais frequente em sequências de DNA com o TFBS TATA-box presente e segundo os resultados dos autores essa classe foi mais representativa em genes com expressão tecido específico; a classe TATA (-) foi determinada para sequências de DNA com o TATAbox ausente e com os TFBSs XCPE1, MTE, Inr e DPE presentes em maior frequência. Essa classe foi mais comum em genes housekeeping. Já para a classe CPE (-) não houve nenhum enriquecimento preferencial para qualquer um dos motivos avaliados e esta classe foi mais associada com os genes responsáveis pela transdução de sinais. Além dessa classificação, os autores observaram que a arquitetura da região Promotora classe TATA $(+)$ é conservada entre todos os organismos avaliados. No entanto, a região Promotora classe TATA (-) apresentou diferenças no enriquecimento de TFBSs tanto para plantas Monocotiledôneas quanto para plantas Dicotiledôneas. Em Monocotiledôneas os TFBSs mais enriquecidos foram XCPE1 e MTE e em plantas Dicotiledôneas os TFBSs mais marcantes foram Inr e DPE [Kumari and Ware, 2013]. Esses trabalhos reforçam a complexidade de análise da re- 
gião Promotora assim como sua diversidade dentro do mesmo organismo, assim como entre diferentes organismos.

\subsubsection{Core Promoter}

A região Core Promoter é a subsequência de DNA responsável pela ancoragem do complexo transcricional RNA pol II e por conseguinte pelo início do processo de transcrição [Yamamoto et al., 2007b]. Em geral o tamanho estimado para o Core Promoter é de 500 nucleotídeos (nt) à montante do início do gene, entretanto, esse valor é arbitrário uma vez que o principal ponto de referência para esta região é o sítio de início de transcrição (TSS). Na sequência de DNA do Core Promoter há inúmeros TFBSs e todos são responsáveis direta ou indiretamente pela ancoragem do complexo transcricional [Adelman and Lis, 2012, Levo and Segal, 2014, Mejía-Guerra et al., 2015, Yamamoto et al., 2011]. Na maioria dos organismos superiores os TFBSs mais frequentes na sequência de DNA do Core Promoter são TATA-box, Inr, BREu, BREd, Y-Patch e ilhas CpG [Capella et al., 2014, Morton et al., 2015, Shahmuradov et al., 2017, Yamamoto et al., 2007b].

O TFBS mais comum na região Core Promoter é o TATA-box. Esse motivo é responsável pela ancoragem da proteína TBP (TATA Binding Protein - TBP) [Adelman and Lis, 2012, Morton et al., 2015, Shahmuradov et al., 2017]. A principal função do TATA-box é montar o complexo transcricional assim como recrutar a RNA pol II para iniciar a transcrição do gene. Em geral o TFBS TATA-box é determinado através da identificação de regiões enriquecidas com os nucleotídeos Timina e Adenina e estas regiões devem estar próximas do TSS com distância não superior a 25 ou 35 nt. Em geral a sequência consenso do TATA-box é TATA(A/T)A(A/T) [Adelman and Lis, 2012, Kumari and Ware, 2013, Shahmuradov et al., 2017]. Diferentes de outros TFBSs presentes no Core Promoter o TATAbox tem sua sequência conservada nos mais diferentes organismos tanto em plantas quanto em mamíferos [Capella et al., 2014, Watson et al., 2015, Yamamoto et al., 2007b].

Apesar do TFBS Inr estar justaposto com o sinal de TSS, ele não é conservado em muitos organismos. De acordo com a literatura a sequência consenso mais comum para Inr é GCC(A/G)CCAUGG. A principal função deste TFBSs é contribuir com o posicionamento correto da RNA pol II durante o início da transcrição gênica [Capella et al., 2014, Kumari and Ware, 2013, Watson et al., 2015, Yamamoto et al., 2007b].

Os sinais BRE upstream (BREu) e BRE downstream (BREd) também estão relacionados com a montagem correta do complexo transcricional. Em geral estes TFBSs são encontrados próximos à região TATA-box, ladeando a sequência consenso do TFBS TATA-box tanto a montante quanto a jusante. Na literatura, estes TFBSs são descritos com as sequências consenso $(\mathrm{A} / \mathrm{C})(\mathrm{G} / \mathrm{C})(\mathrm{C} / \mathrm{G})(\mathrm{G} / \mathrm{A})(\mathrm{C} / \mathrm{A}) \mathrm{GCC}$ para BREu e $(\mathrm{A} / \mathrm{T}) \mathrm{TTT}(\mathrm{T} / \mathrm{C}) \mathrm{T}$ para BREd [Adelman and Lis, 2012, Kumari and Ware, 2013, Levo and Segal, 2014, Watson et al., 2015].

Outro sinal muito frequente na região Core Promoter é o TFBS Y-patch. Este TFBS foi encontrado exclusivamente em plantas e tem apresentado distribuição similar a observada 
para as ilhas CpG de mamífero. Porém, o TFBS Y-patch não apresenta qualquer característica de metilação como é observado na sequência de DNA com ilhas CpG. O TFBS Y-patch apresenta sequência consenso conservada TTCTTCTTC e esta sequência está localizada próximo do sinal de TSS com distância não superior a 60 nt à montante ou à jusante [Yamamoto et al., 2007a,b]. Todos os sinais descritos anteriormente não são imprescindíveis para o Core Promoter uma vez que outros sinais podem substituí-los. Um exemplo dessa mudança é a substituição de ilhas CpG pelo TFBS Y-Patch na região Core Promoter de plantas. Além disso, a região Promotora classe TATA-less de plantas apresentou outros TFBSs enriquecidos na região Core Promoter: MTE, XCPE1, Inr e DPE. Ademais, o enriquecimento destes TFBSs foi diferente nos dois grupos de plantas: Monocotiledôneas apresentaram a região Core Promoter com os TFBSs MTE e XCPE1 e plantas Dicotiledôneas os TFBSs Inr e DPE [Kumari and Ware, 2013, Yamamoto et al., 2007b, 2011].

\subsubsection{Promotor Proximal}

A sequência de DNA à montante do Core Promoter é denominada de Promotor Proximal. O tamanho do Promotor Proximal pode variar entre diferentes organismos, no entanto, não ultrapassa a faixa de 1500 nt de distância do início do gene. Devido a extensão e o posicionamento do Promotor Proximal todos os TFBSs presentes nesta região podem estar ou não relacionados com o recrutamento do complexo transcricional [Dolfini et al., 2009, Narlikar and Ovcharenko, 2009, Salvini et al., 2012]. Em geral essa relação é indireta. Por exemplo, o TFBS CCAAT box é comumente encontrado na região do Promotor Proximal, entretanto, esse motivo é responsável pela ancoragem de diferentes TFs da família NF (Nuclear Factor - NF). Os TFs NF são essenciais para o recrutamento dos TFs gerais, e por sua vez, responsáveis pela montagem do complexo transcricional [Dolfini et al., 2009, Salvini et al., 2012]. Além disso, o motivo CCAAT box apresenta papel fundamental no reposicionamento do nucleossoma na região Promotora; tanto para no Core Promoter quanto no Promotor Proximal [Dolfini et al., 2009, Narlikar and Ovcharenko, 2009, Watson et al., 2015].

\subsection{Identificação in vivo do sinal de TSS}

O complexo processo de expressão gênica é controlada por diferentes subsequências de DNA chamadas de Sequências Regulatórias (SR). A principal SR para todos genes codificantes de proteínas é conhecida como região Promotora. Em geral a região Promotora fica localizada a upstream do gene codificante de proteína [Mejía-Guerra et al., 2015, Ni et al., 2010, Shiraki et al., 2003, Tokizawa et al., 2017]. Em razão ao seu posicionamento, a região Promotora é responsável pela ancoragem dos Fatores de Transcrição Gerais e pelo recrutamento da RNA pol II [Kumari and Ware, 2013, Mejía-Guerra et al., 2015, Morton et al., 2014, 2015, Shahmuradov et al., 2017].

Com o avanço da tecnologia foi possível realizar a identificação do sinal de TSS através 
da molécula de pré-mRNA usando duas técnicas: cap-trapper e oligo-capping [Dreos et al., 2016, Ni et al., 2010, Shiraki et al., 2003, Tokizawa et al., 2017]. As duas técnicas usam a extremidade 5' do pré-mRNA como alvo para recuperar a localização do TSS, uma vez que está informação é mantida através do processo de capping do pré-mRNA. Por meio destas técnicas, diferentes protocolos para construção de bibliotecas de full length cDNA (fl-cDNA) foram desenvolvidos [Mejía-Guerra et al., 2015, Morton et al., 2014, Sakai et al., 2013, Shiraki et al., 2003].

No início a identificação do TSS era realizado por meio do sequenciamento destas bibliotecas e a região 5' de cada fl-cDNA era mapeado no genoma para identificação do TSS [Dreos et al., 2016, Ni et al., 2010, Sakai et al., 2013, Shiraki et al., 2003]. Entretanto. apesar de auxiliar na identificação do TSS, esse procedimento apresenta baixo rendimento para genes com expressão reduzida além do elevado custo de execução [Dreos et al., 2016, Ni et al., 2010, Shiraki et al., 2003]. Contudo, atualmente, estas limitações foram superadas com o desenvolvimento do sequenciamento de nova geração e a utilização de sequências mais curtas. Através dessa mudança diferentes estratégias foram desenvolvidas tais como OligoCap, CAGE, deepCAGE e PEAT [Dreos et al., 2016, Ni et al., 2010, Shiraki et al., 2003, Tokizawa et al., 2017]. Com este avanço foi possível elevar o rendimento e a precisão da descoberta in vivo do TSS para diferentes genes. Até momento o uso destas técnicas já foi realizado com sucesso em diferentes organismos tais como Milho e Arabidopsis [Dreos et al., 2016]. Usando dados gerados por estas técnicas, o banco EPD conseguiu resolver mais de 17081 sinais de TSS para aproximadamente 15828 genes em Milho (RefGen-v3/zm3) e esse valor corresponde a 59\% dos genes já descritos para Milho [Dreos et al., 2016, Mejía-Guerra et al., 2015]. Já em Arabidopsis a identificação do sinal de TSS foi realizada para $78 \%$ dos genes descritos (TAIR10/araTha1) e essa cobertura foi alcançada utilizando diferentes estratégias como PEAT, deepCAGE, CAGE e OligoCap [Cumbie et al., 2015, Dreos et al., 2016, Morton et al., 2014, Tokizawa et al., 2017]. Essa avanço na rotulação do sinal de TSS também tem sido observado em outros organismo como camundongo, mosca-das-frutas e humanos [Dreos et al., 2016]. Embora esse avanço esteja limitado a organismos modelos, a informação gerada neste grupo de organismos pode auxiliar na identificação in silico do sinal de TSS através do desenvolvimento de novas ferramentas computacionais [Dreos et al., 2016].

\subsection{Identificação in silico do sinal de TSS}

O maior desafio na rotulação da região Promotora de organismos não modelo está na falta de dados experimentais que auxiliam a identificação do TSS e por conseguinte contribuem com a correta classificação da região Promotora [Abeel et al., 2009, Morton et al., 2015, Narlikar and Ovcharenko, 2009, Shahmuradov et al., 2017]. Porém, essa lacuna pode ser resolvida através da aplicação de ferramentas computacionais capazes de modelar a realidade. 
Assim como na identificação de genes codificadores de proteínas, a rotulação da região promotora pode ser realizada através de procedimentos in silico. Seguindo o paradigma da predição gênica, a rotulação da região promotora pode ser obtida através de diferentes sítios responsáveis pela montagem do complexo transcricional [Kumari and Ware, 2013, Morton et al., 2015, Narlikar and Ovcharenko, 2009, Shahmuradov et al., 2017, Shiraki et al., 2003]. Entre eles podemos destacar o motivo TATA-box como principal sinal utilizado na modelagem da região promotora [Morton et al., 2015, Shahmuradov et al., 2017]. Contudo, somente esta característica não é capaz de rotular adequadamente a região promotora uma vez que apenas 10 e no máximo 30\% de todos os genes codificantes de proteínas apresentam este sinal na região promotora [Dreos et al., 2016, Kumari and Ware, 2013, Mejía-Guerra et al., 2015, Shiraki et al., 2003]. Por isso a implementação de ferramentas para predição da região Promotora modelada com diferentes características são fundamentais para correta rotulação da sequência de DNA [Morton et al., 2015, Shahmuradov et al., 2017]. Na literatura há um grande número de ferramentas disponíveis que buscam atender essa demanda, no entanto, a acurácia destes modelos até recentemente era muito reduzida e o principal motivo para este desempenho é associado com a disponibilização de dados de baixa qualidade [Abeel et al., 2009, Narlikar and Ovcharenko, 2009]. Nessa condição tanto o processo de treinamento quanto o mecanismo de avaliação destes modelos eram comprometidos. Dessa forma era comum que as ferramentas desenvolvidas na última década apresentassem valores de predição do sinal de TSS inferiores a 35\% [Abeel et al., 2009, Ladunga, 2010, Narlikar and Ovcharenko, 2009, Shahmuradov et al., 2017].

Porém nos últimos anos o processo de rotulação da região Promotora tem apresentado ganhos significativos e os valores de predição correta do TSS estão acima dos $35 \%$ anteriores. Neste grupo podemos destacar as ferramentas TIPR [Morton et al., 2015] e TSSPlant [Shahmuradov et al., 2017]. Estas duas ferramentas o valor de precisão ficaram superior a 80\%. Embora estes resultados sejam animadores e demonstram uma evolução no processo de identificação in silico do TSS, uma análise mais cuidadosa deve ser considerada tanto para o conjunto de sequências que são utilizadas na criação dos modelos de predição quanto ao tipo de arcabouço probabilístico utilizado por estes modelos.

Para avaliação da região Promotora, as duas ferramentas necessitam que a sequência de DNA analisada tenha a orientação do sinal de TSS disponível; ou seja, o sinal de TSS deve estar anotado. Este tipo de configuração visa delimitar as fronteiras de início e fim da sequência de DNA analisada, entretanto, esse tipo de característica limita aplicação destas ferramentas nos organismos onde não há nenhuma evidência sobre a localização do sinal de TSS [Morton et al., 2015, Shahmuradov et al., 2017].

Por fim a identificação do sinal de TSS através de experimentos in vivo tem evoluído com passar dos anos e esse fenômeno tem contribuído com o desenvolvimento de ferramentas de predição ab initio mais robustas. Assim o desenvolvimento de novas ferramentas deverá ser adequada para atender esta nova demanda de informações e ao mesmo tempo ser capaz de realizar a sua tarefa de predição com reduzida heurística; de forma mais simples e autônoma. 


\subsection{Sítios de ligação para Fator de Transcrição}

\subsubsection{Principais características para rotulação de TFBS}

A capacidade de regulação gênica dos TFs é devida a dois domínios proteicos presentes no TF: o domínio de Ativação e o domínio de Interação Proteína-DNA. O domínio de Ativação é responsável por determinar qual tipo de regulação será realizada e o domínio de Interação Proteína-DNA é responsável pelo direcionamento da regulação para um alvo específico. Por isso a determinação de TFBSs que estão associados a um específico TF é essencial para inferir quais genes podem ser regulados pelo TF. Dessa forma tanto o posicionamento quanto a sequência consenso do TFBS são fundamentais para o processo de regulação gênica [MacQuarrie et al., 2011, Nakashima et al., 2014, Yu et al., 2015]. Em geral a sequência de DNA dos TFBSs é curta e o tamanho não ultrapassa a janela de 6 a 22 nt e a principal função apontada para os TFBSs é posicionar corretamente o TF na fita de DNA [Watson et al., 2015]. Na literatura há vários trabalhos que evidenciam a importância da identificação e caracterização dos TFBSs na região do Promotor Proximal. Além disso, redes regulatórias ou grupos de genes co-expressos já foram estimados a partir da identificação dos TFBSs na região Promotora [de los Reyes et al., 2015, Kaufmann et al., 2010, MacQuarrie et al., 2011, Meier et al., 2008].

A caracterização de TFBS na região a montante de genes diferencialmente expressos pode contribuir com a compreensão dos mecanismos utilizados na regulação diferencial de genes [Meier et al., 2008, Zambelli et al., 2012]. Com isso, o posicionamento, a distribuição e a concentração de TFBSs na região upstream do gene alvo podem contribuir para inferência de redes regulatórias [de los Reyes et al., 2015, Kaufmann et al., 2010, MacQuarrie et al., 2011]. Essa expectativa já foi observada na predição ab initio de redes regulatórias em Arroz. Meier et al. demonstraram que a caracterização de TFBSs na região Promotora favorecia a identificação de redes de regulação gênica em Arroz. Usando essa abordagem, os autores conseguiram caracterizar mais de 244 genes com região Promotora similar e destes genes, após validação experimental, mais de 70\% apresentavam co-expressão [Meier et al., 2008].

\subsubsection{Cis-Regulatory Module}

Como descrito anteriormente na seção Promotor Proximal, a região a montante do Core Promoter concentra grande número de TFBSs não associados com a montagem do complexo transcricional. Em geral estes TFBSs estão agrupados em mais de um único sítio e são separados um do outro por apenas algumas dezenas de nt. Em razão dessa configuração, todos os TFBSs presentes neste agrupamento são denominados módulos de elementos regulatórios em cis ou simplesmente CRM. Da mesma forma que um único TFBS pode realizar o controle da expressão de genes através de estímulos abióticos e bióticos, os CRMs também podem realizar tal tarefa [Levo and Segal, 2014, Shlyueva et al., 2014, Spitz and Furlong, 2012]. Porém o controle realizado pelos CRMs é mais complexo e este pode ser classificado como 
Potenciador quando diferentes TFs trabalham em conjunto, Inibidor da transcrição de genes quando um TF inativa a ligação de outros TFs e Insulador quando bloqueia a interação entre diferentes TFs. Acredita-se que esta é a razão para qual os CRMs estão localizados na região do Promotor Proximal ou a milhares de bases de distância do gene alvo [Levo and Segal, 2014, Shlyueva et al., 2014, Spitz and Furlong, 2012].

\subsection{Identificação de TFBS usando ensaios biológicos}

\subsubsection{Identificação in vitro de TFBS}

Inicialmente a identificação dos TFBSs era realizada através de ensaios in vitro usando técnicas similares as executadas para análise de expressão gênica, tais como microarranjo, evolução sistemática de ligantes por enriquecimento exponencial (SELEX) e expressão heteróloga. De todas técnicas utilizadas in vitro, o PBM (Protein-Binding Microarray) foi a técnica que apresentou maior rendimento para descoberta de TFBSs [Franco-Zorrilla and Solano, 2017].

Em 2014, Franco-Zorrilla et al. caracterizaram a especificidade da interação sequência de DNA e proteína para mais de 60 de TFs em A. thaliana. Essa caracterização foi realizada usando a técnica PBM. Neste trabalho os autores observaram que aproximadamente $40 \%$ dos TFs apresentavam mais de um sítio de ligação. Além disso de todos TFBSs caracterizados mais de $80 \%$ apresentaram associação funcional com expressão de genes em $A$. thaliana. Ademais neste trabalho os autores apresentaram elevada correlação entre o TFBSs preditos no ensaio PBM (in vitro) com a descoberta de regiões com hipersensibilidade DNase I (experimento in vivo para descoberta de SRs) [Franco-Zorrilla et al., 2014]. Estas regiões com hipersensibilidade DNase I são consideradas livre de nucleossoma e portanto apresentam a sequência de DNA disponível para interação com TFs ou com outras proteínas regulatórias [Franco-Zorrilla and Solano, 2017].

\subsubsection{Identificação in vivo de TFBS}

Hoje em dia a identificação de TFBSs é também realizada através de experimentos in vivo usando diferentes técnicas com elevado rendimento e aplicação em todo o genoma. As principais técnicas são Imunoprecipitação da Cromatina com Sequenciamento (ChIP-Seq) e os ensaios de hipersensibilidade com DNAse I [Franco-Zorrilla et al., 2014, Smith and Matthews, 2016, Stormo and Zhao, 2010].

Em plantas a técnica de ChIP-Seq tem sido utilizada em diferentes ensaios desde florescimento até respostas a estímulos abióticos e bióticos. Entretanto o conjunto de plantas utilizadas nestes ensaios é limitado e o principal organismo de estudo é Arabidopsis [Franco-Zorrilla and Solano, 2017]. Com a técnica de ChIP-Seq a identificação de TFBS tem sido realizada em diferentes regiões do genoma como éxons, íntrons, além da região promo- 
tora [Franco-Zorrilla and Solano, 2017, Smith and Matthews, 2016, Stormo and Zhao, 2010]. Apesar da aplicação em larga escala do ChIP-Seq, para maioria dos estudos realizados com esta técnica há reduzida correlação entre a identificação do TFBS e a expressão do gene alvo. A principal razão para essa discrepância está no momento da realização dos ensaios de ChIP-Seq [Franco-Zorrilla and Solano, 2017, Smith and Matthews, 2016, Stormo and Zhao, 2010]. Nos experimentos de ChIP-Seq o cenário de captura da interação proteína-DNA é instantâneo e geralmente estes ensaios desconsideram a dinâmica do processo de regulação realizado pelo complexo TF-TFBS. Então uma das soluções seria a realização do ensaio de ChIP-Seq em conjunto com os ensaios de Transcriptoma. Ademais, outro ponto associado a baixa correlação dos resultados de ChIP-Seq com o transcriptoma está relacionado com o diferente grau de interação do TF com a sequência de DNA: alta afinidade ou de baixa afinidade. Este cenário é muito comum nos experimentos de ChIP-Seq principalmente durante o processo de fixação do complexo proteína-DNA. Dessa forma é possível que a maioria das interações proteína-DNA recuperadas pelos ensaios de ChIP-Seq não sejam funcionais [Franco-Zorrilla and Solano, 2017, Ladunga, 2010, Smith and Matthews, 2016].

Todos os experimentos (in vitro ou in vivo) permitiram capturar o cenário genômico onde havia alguma hibridização entre proteínas e a fita de DNA (TF-TFBS). Entretanto a contribuição destas tecnologias na descoberta das interações proteína-DNA pode ser onerosa e o custo para realização destes ensaios é inviável para todos os organismos conhecidos. Ademais, algumas destas técnicas podem apresentar sérias limitações quando adaptadas a organismos não modelo [Franco-Zorrilla and Solano, 2017, Stormo and Zhao, 2010].

Para reverter essa dificuldade, principalmente para organismos não modelo, a identificação dos TFBSs tem sido realizada através de análises in silico [Bailey et al., 2009, Stormo and Zhao, 2010, Yu et al., 2015]. Assim através do uso de diferentes ferramentas e algoritmos de predição é possível fazer a rotulação de todo genoma para regiões com potencial de ligação proteína-DNA sem a necessidade de inúmeros experimentos [Durbin et al., 1998, Mount, 2004, Stormo and Zhao, 2010]. Outra característica importante na análise in silico está na compilação de dados gerados em outros organismos filogeneticamente próximos [Edwards et al., 2009, Ladunga, 2010].

\subsection{Identificação in silico de TFBS}

Os primeiros modelos para a identificação de TFBS eram baseados na especificidade dos TFs com sequências de DNA (interação proteína-DNA). Em geral essa característica era conhecida, ou seja, a sequência consenso do TFBS já estava rotulada. Portanto, o objetivo destes métodos era apenas identificar a região ou o local genômico do TFBS na sequência de DNA [Edwards et al., 2009, Ladunga, 2010]. Contudo, algumas interações TF-TFBS não são conhecidas e por isso a sequência consenso do TFBS não está rotulada e muito menos o local onde ela ocorre na sequência de DNA. Para essa situação a identificação do TFBS deve 
ser realizada através de modelos probabilísticos usando a técnica de predição de novo. Com esta técnica de predição, o modelo probabilístico realiza todo o processo de identificação sem a necessidade de TFBSs bem caracterizados [Edwards et al., 2009, Ladunga, 2010].

Em 2015 Yu et al. estimaram mais de 250 interações TF-TFBS em milho. Neste trabalho, os autores utilizaram mais de 22 transcriptomas analisando desde semente seca até momento de germinação. Para obter as interações entre TF e TFBS, os autores construíram 30 grupos de genes co-regulados. Estes conjuntos foram reunidos observando a mesma classificação no Gene Ontology (GO). Ademais, em cada conjunto de gene co-regulado a região Promotora foi isolada de forma arbitrária - com tamanho de 1000 nt à montante da região de TSS e 200 nt à jusante do TSS. Em seguida, a predição e identificação dos TFBSs foi realizada com as ferramentas MEME e TOMTOM, respectivamente. Para cada TFBS identificado, os autores determinaram o TF correlato usando diferentes banco de dados com os sítios de TFBS anotados e com seus respectivos TFs conhecidos. Além dessa metodologia os autores apresentaram outro fluxo de trabalho no qual a base para identificar novos TFBSs em Milho foi orientada pela interações TF-TFBS já descritas em Arroz e Arabidopsis. Por fim, para as duas metodologias, mais de 1,340 TFBSs foram preditos em Milho e acima de 250 interações TF-TFBS foram validadas neste estudo [Yu et al., 2015].

A partir da observação destes resultados, é possível esperar que a compilação de diferentes informações como a expressão gênica, dados de similaridade e a predição in silico de TFBSs podem contribuir para estimar qual interação TF-TFBS pode ocorrer na região promotora, mesmo para organismos onde a evidência experimental da interação TF-TFBS é ausente [Yu et al., 2015]. Nos tópicos seguintes nós apresentaremos os modelos de descoberta por mapeamento e na próxima seção nós apresentaremos os modelos de predição probabilísticos [Durbin et al., 1998, Edwards et al., 2009, Ladunga, 2010, Mount, 2004].

\subsubsection{Mapeamento de TFBS}

O princípio da predição de TFBS baseada no mapeamento se baseia na possibilidade de que cada subsequência de tamanho $n$ possa ser um possível TFBS. No entanto, para confirmar a presença do motivo na sequência alvo é preciso avaliar, através de diferentes testes estatísticos, se o referido TFBS está mais enriquecido na sequência alvo do que na sequência de DNA do modelo de background (sequências aleatórias ou conjunto de sequências que não apresentem relação direta com a sequência alvo). Portanto, além dos TFBS escolhidos para o mapeamento, a escolha do conjunto de background é fundamental para o processo de mapeamento [Edwards et al., 2009, Ladunga, 2010, Rombauts et al., 2003]. Na literatura há inúmeras estratégias para a construção do conjunto de background e entre os principais modelos que podemos destacar estão os baseados em cadeia de Markov (CV), embaralhamento da sequências de DNA que estejam mais próximas da realidade biológica avaliada, além da geração de sequências aleatórias [Rombauts et al., 2003]. De forma geral, a predição baseada no mapeamento de TFBS conhecidos apresenta a vantagem de ser rigoroso e exaustivo. 
Porém, quando a busca é realizada para motivos grandes e altamente degenerados esse tipo de modelo é menos eficaz [Edwards et al., 2009, Ladunga, 2010, Rombauts et al., 2003].

\subsubsection{Mapeamento usando TFBS anotados}

Em geral, o mapeamento de TFBSs anotados é baseado em informações acessadas em Bancos de Dados que armazenam todo conteúdo sobre os TFBSs caracterizados e identificados por meio de experimentos bioquímicos e genéticos [Edwards et al., 2009, Ladunga, 2010, Zambelli et al., 2012]. O grande desafio dessa abordagem é extrair da literatura informações que realmente são relevantes para o conhecimento dos TFBSs. Em geral, esse trabalho é realizado por especialistas com capacidade de discernir sobre quais informações são importantes para serem armazenadas e utilizadas. Antes do desenvolvimento da tecnologia de informação, esse trabalho era mais custoso e exaustivo, porém, atualmente diferentes ferramentas de prospecção de dados estão sendo aplicadas para extrair essa informação na literatura específica. Hoje, a maioria destes recursos estão acessíveis via web tanto para análise usando interface gráfica (serviço online) quanto para análise in loco através do download dos arquivos [Edwards et al., 2009, Ladunga, 2010].

\subsubsection{Mapeamento usando sequências consenso ou k-mers}

O Mapeamento de sequências consenso ou k-mers para diferentes TFBSs numa sequência de DNA é considerado o mecanismo mais simples de descoberta de TFBS [Edwards et al., 2009, Yamamoto et al., 2007a]. O algoritmo árvore de sufixo foi o principal mecanismo para descoberta de TFBS nas últimas décadas [Rombauts et al., 2003]. Nessa abordagem a busca do TFBS era realizada através de diferentes subsequências, cada subsequência era mapeada na sequência alvo e somente após identificação da subsequência mapeada a busca pelo TFBS continuava. Esse processo era repetido para todas subsequências do TFBS. Para esse tipo de análise, a busca do TFBS é limitada por dois fatores: tamanho do TFBS e pela sequência consenso do TFBS [Edwards et al., 2009, Ladunga, 2010, Rombauts et al., 2003].

\subsubsection{Mapeamento usando sobre-representação de TFBS}

O Mapeamento de TFBS usando sobre-representação utiliza a informação adicional de quais TFs influenciam a expressão gênica de um determinado grupo de genes para em seguida realizar o mapeamento dos seus respectivos TFBSs. Dessa forma a descoberta dos TFBSs é realizada através do mapeamento de TFBSs selecionados em dois conjuntos de sequências distintos, um conjunto será relacionado com a regulação do TF e outro com sequências de DNA sem relação com o TF. Neste tipo de abordagem a identificação de TFBS é suportada por modelos estatísticos discriminativos [Edwards et al., 2009, Ladunga, 2010]. O programa HOMER foi projetado para fazer esse tipo de busca discriminatória. Esse aplicativo realiza a busca de TFBS através do enriquecimento diferencial dos TFBSs utilizando dois conjuntos 
de sequências. Dessa forma um dos conjuntos deverá ser formado por sequências de DNA de genes co-regulados contra outro conjunto de genes não co-regulado pelo TF avaliado [Heinz et al., 2010]. A identificação dos TFBSs é realizada pelo enriquecimento através da distribuição hipergeométrica de cada TFBS nos dois conjuntos avaliados. O Mapeamento de TFBS usando sobre-representação não apresenta nenhuma restrição quanto a variação da sequência consenso e muito menos com o número de ocorrências do mesmo TFBS na sequência alvo [Heinz et al., 2010].

\subsubsection{Mapeamento de TFBSs usando relação filogenética}

A principal motivação para abordagem filogenética está na observação de que na sequência de DNA há dois grupos de subsequências: um funcional e outro não funcional. Com isso, a predição de SRs pode ser realizada através de informações já rotuladas em outras espécies. Esse tipo de abordagem já foi utilizada para aperfeiçoar a identificação de TFBS através do mapeamento de TFBS já caracterizados em outros organismos [Chiang et al., 2003, Siddharthan et al., 2005].

\subsubsection{Mapeamento com diferentes TFBSs - Clusters de TFBSs}

Um gene pode ser regulado por diferentes TFs ou então, um único TF pode regular diferentes genes com função similar. Em geral, esse mecanismo de regulação apresenta diferentes TFBSs agrupados na mesma região da sequência de DNA. Acredita-se que SRs similares são alvos putativos da ação dos mesmos TFs e por conseguinte responsáveis pela regulação de genes com funções similares ou relacionadas. Essa hipótese já foi utilizada para identificar genes co-expressos através da caracterização e identificação de TFBSs localizados na região promotora de genes diferencialmente expressos [Meier et al., 2008]. E em outro trabalho, Schultheiss et al. [2009] demonstraram que a predição de grupos TFBSs pode ser realizada através de modelos discriminatórios como o SVM (Support Vector Machines SVM). Nesse modelo os autores conseguiram integrar diferentes características relacionadas ao agrupamento de TFBSs, tais como: a sequência consenso, a conservação dessa sequência em diferentes regiões do genoma e a dependência posicional destas sequências em relação a outros TFBS. De acordo com Schultheiss et al. [2009] o modelo apresentou melhor desempenho quando comparado com outros modelos de predição desenvolvido exclusivamente para identificação de apenas um único TFBS.

\subsection{Predição de novo de TFBS}

Novos candidatos a TFBS podem ser propostos utilizando métodos de predição de novo. Dois modelos muito utilizados para esta tarefa são o Modelo de Maximização de Expectativa e o Gibbs Sampling. 


\subsubsection{Modelo de Maximização da Expectativa}

O Método Probabilístico de Maximização da Expectativa (Expectation-Maximization EM) é um procedimento estatístico que apresenta duas etapas principais - expectativa e maximização. Na primeira etapa, uma PWM (Position Weight Matrix - PWM) inicial é aplicada nas posições da sequência alvo. Na etapa seguinte, o peso de cada motivo gerado na etapa anterior é usado para criar uma nova PWM maximizada. As duas etapas são alternadas até encontrar a PWM com maior probabilidade [Durbin et al., 1998, Ladunga, 2010, Mount, 2004].

Neste método, acredita-se que cada sequência é composta por duas partes - uma com TFBS e a outra sem o TFBS - e que estas partes têm propriedades estatísticas diferentes. Assim para encontrar o TFBS na sequência, o método calcula diferentes matrizes do tipo $\mathrm{P}(b, i)$, onde $\mathrm{P}$ é a probabilidade de encontrar o nucleotídeo $b$ na posição $i$ tanto para região com, assim como para sequência sem o TFBS. Entretanto, nas sequências de DNA sem o sinal do TFBS uma matriz do tipo $\mathrm{P}(b, 0)$ é calculada, onde $\mathrm{P}$ é a probabilidade de observar qualquer nucleotídeo $b$ em qualquer posição da sequência. Ademais, para todos os possíveis locais de ligação - coordenada genômica de cada TFBS na sequência de DNA - são igualmente prováveis de abrigarem o TFBS, assim, para cada possível sítio uma matriz é gerada. O método EM precisa realizar várias iterações para refinar as probabilidades $\mathrm{P}(b$, i) de modo a maximizar-las em relação ao modelo de background $\mathrm{P}(b, 0)$ [Edwards et al., 2009, Ladunga, 2010]. Contudo, o método EM não garante que o modelo irá convergir para a solução correta, ou para a solução com maior probabilidade sobre todas as escolhas possíveis.

O resultado do algoritmo EM depende da configuração inicial da matriz de caracterização do TFBS. Assim, o procedimento padrão para aplicação da metodologia recomenda o uso de várias matrizes iniciais. Resultados finais recorrentes representam melhores candidatos para novos TFBS [Bailey et al., 2009], que

\subsubsection{Modelo Gibbs Sampling}

Assim como no método de EM, o modelo Gibbs Sampling busca encontrar o TFBS mais provável. Porém, este algoritmo de otimização não apresenta um máximo global, convergindo para soluções locais. Como o modelo possui natureza estocástica produzindo soluções diferentes para os mesmos parâmetros iniciais, ele é sempre aplicado em repetição [Durbin et al., 1998, Mount, 2004] visando encontrar melhores candidatos.

O processo de execução do algoritmo de Gibbs Sampling pode ser brevemente descrito da seguinte maneira: A partir de um conjunto x de sequências e um tamanho $n$ pré determinado, o algoritmo retira uma sequência $s$ deste conjunto. Então, sorteia aleatoriamente um local em cada sequencia do conjunto restante $\left(x_{s}\right)$. As vizinhanças de tamanho $n$ de cada posição são utilizadas para caraterizar uma PWM. Em seguida esta PWM é utilizada para analisar a sequência $s$. Os valores de probabilidade desta análise são utilizados como distribuição para uma nova posição candidata na sequência $s$. Em seguida, é colocada de volta no conjunto e 
nova sequência é retirada. Repete-se o processo de caracterização de uma nova PWM. Esse procedimento é repetido até convergir para para uma PWM de equilíbrio ou quando um limite de iterações determinado pelo usuário é atingido.

\subsection{Predição $a b$ initio de TFBS}

\subsubsection{Cadeias Ocultas de Markov}

Em geral, os modelos de HMMs utilizam a estratégia intrínseca como principal mecanismo para rotular a sequência de DNA e estes modelos são formados por dois conjuntos: um conjunto de estados ocultos que emitem os nucleotídeos com probabilidades definidas, e o outro conjunto é criado com as probabilidades de transição de um estado para o outro estado. Os modelos baseados em HMMs utilizam algoritmos diferentes para encontrar o melhor resultado de rotulação da sequência, entre eles os algoritmos Baum-Welch e Viterbi [Durbin et al., 1998, Mathelier and Wasserman, 2013, Mount, 2004].

O TFFM (Transcription Factor Flexible Models - TFFM) é um exemplo de modelo probabilístico baseado em HMM para realizar predição de SRs [Mathelier and Wasserman, 2013]. Basicamente, o processo de predição realizada pelo TFFM considera duas características principais dos TFBSs: a dependência entre os nucleotídeos e a variabilidade do tamanho da sequência consenso. Para capturar estas características, o modelo utiliza uma gHMM (generalized Hidden Model Markov - gHMM) de dois estados: um estado é utilizado para identificar as sequências vizinhas ao TFBS e outro estado para a sequência de DNA com o TFBS. Ademais, dentro do estado de TFBS, há outro modelo probabilístico baseado em HMM para modelar a sequência consenso do TFBS. Nesse último modelo cada posição dentro do motivo é representado com um estado na HMM. Por fim, cada estado emite um nucleotídeo com probabilidade dependente do nucleotídeo encontrado no estado anterior, ou seja, a captura da dependência entre nucleotídeos é realizada através das probabilidades de emissão dos nucleotídeos nas posições $p$ e $p$-1 da sequência alvo. Na avaliação do modelo os autores utilizaram dois conjuntos de sequências. Um conjunto foi utilizado para avaliar a capacidade do modelo em diferenciar o TFBS das regiões vizinhas ao motivo e o outro foi utilizado para avaliar a capacidade do modelo de encontrar TFBS de tamanho variável. De acordo com Mathelier and Wasserman, nos dois conjuntos testados, o modelo TFFM foi igual ou superior aos métodos tradicionais de predição de TFBS; mais especificamente os modelos de predição baseados em PWM [Mathelier and Wasserman, 2013]. A figura 1.5 apresenta o modelo de predição proposto Mathelier and Wasserman [2013]. Nesse modelo, o objetivo foi rotular sequências de DNA em duas classes: região de background e região com sinal de TFBS. Além disso, como apresentado na figura, o modelo foi desenvolvido para capturar a dependência entre os nucleotídeos adjacentes mais a identificação de TFBSs com diferentes tamanhos de sequência consenso [Mathelier and Wasserman, 2013].

Com o objetivo de aperfeiçoar a identificação de TF-TFBS, Gusmão et al. construíram 


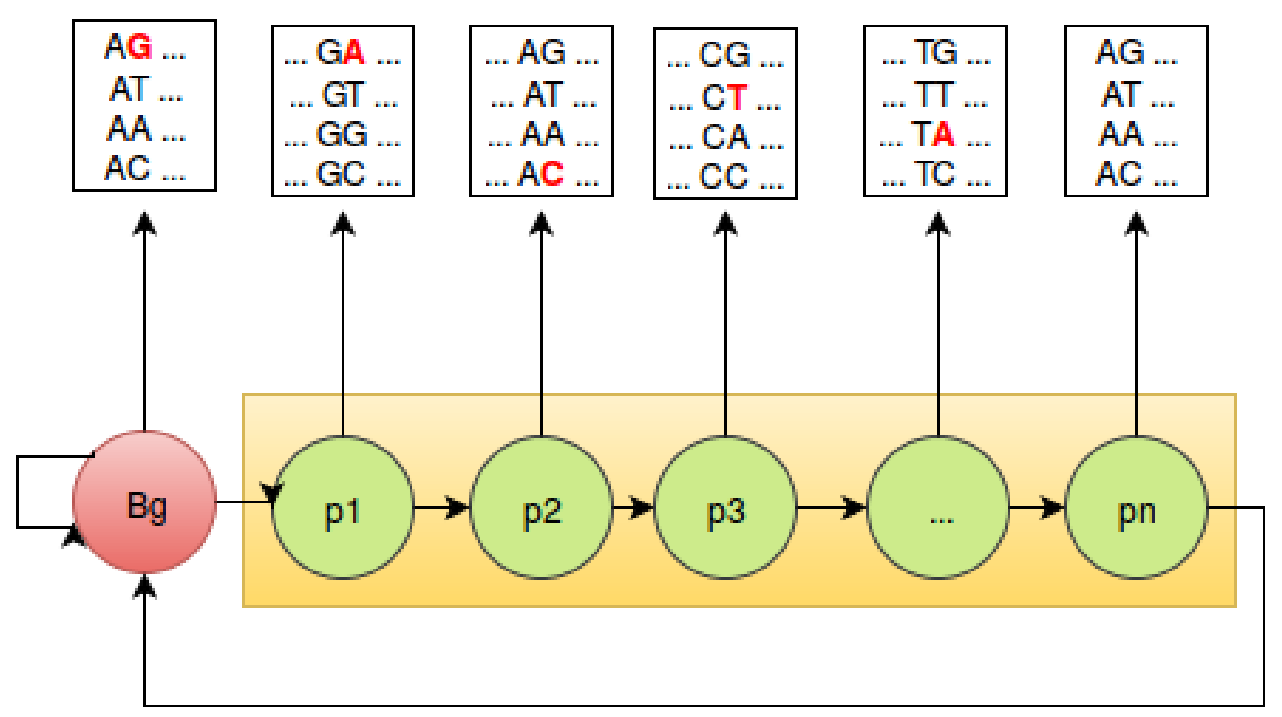

Figura 1.5: Representação gráfica do modelo TFFM

Representação do Modelo proposto por Mathelier and Wasserman [2013].

um modelo de predição de TFBS que integra as duas estratégias de predição: intrínseca e extrínseca. Para esse modelo, os autores utilizaram informações oriundas de diferentes experimentos de hipersensibilidade com DNAse I e modificação de histonas [Gusmão et al., 2012]. Para os autores, o objetivo destes dados é auxiliar a determinação de quais regiões da sequência de DNA estão aptas para alocar alguma interação TF-TFBS. Então, para capturar essa informação, os autores utilizaram o modelo probabilístico HMM multivariado [Gusmão et al., 2012]. Usando esse modelo de HMM, Gusmão et al. conseguiram rotular diferentes regiões com a sequência de DNA apresentando marca de cromatina aberta. A partir dessa seleção, um conjunto de TFBS foi mapeado nestas sequências de DNA com cromatina aberta e, de acordo com autores, a implementação dos dados - hipersensibilidade com DNAse I e modificação de histonas - possibilitou maior sensibilidade na predição das interações TF-TFBSs sem prejudicar a especificidade do processo de predição [Gusmão et al., 2012]. A figura 1.6 apresenta o modelo de HMM multivariado proposto pelo trabalho de Gusmão et al. [2012]. De acordo com autores, a principal característica do modelo foi identificar regiões no genoma com elevada chance de abrigar TFBSs. 


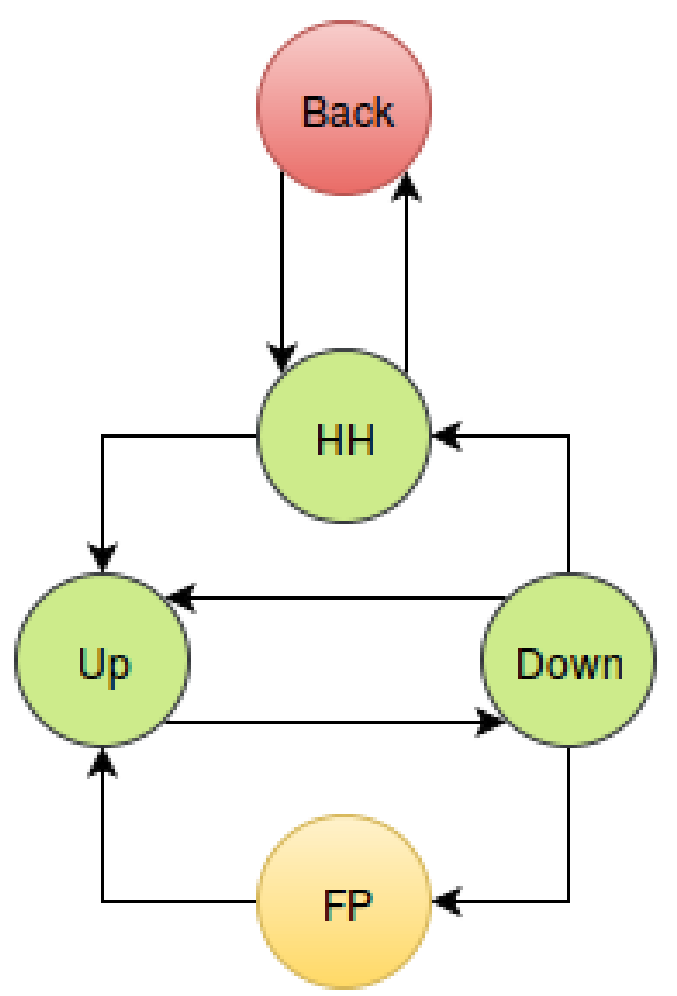

Figura 1.6: Representação gráfica do modelo de HMM Adaptação do modelo proposto por [Gusmão et al., 2012]. 


\section{Capítulo 2}

\section{Material e Métodos}

\subsection{Seleção de sequências de DNA}

Todo processo de análise da região promotora foi orientado para sequências de DNA de cana-de-açúcar SP80-3280, Arabidopsis thaliana, Drosophila melanogaster, Gallus gallus, Homo sapiens, Saccharomyces cerevisiae, Schizosaccharomyces pombe e Oryza sativa com distância variando de 500 nt a 10001 nt do início de cada gene anotado. A tabela 2.1 apresenta resumo geral sobre o conjunto de dados usados neste trabalho.

\subsubsection{Genes de interesse em cana-de-açúcar}

A análise de regiões regulatórias em cana-de-açúcar foi realizada em três genes: Sugarcane drought-responsive 1 (Scdr1) [Begcy et al., 2012], Sugarcane Sucrose Synthase (ScSuSy) (Souza, GM, et 2018 - manuscrito em revisão) e Sugarcane phenylalanine ammonia-lyase (ScPAL) (Souza, GM, et 2018 - manuscrito em revisão).

O gene $S c d r 1$ está associado com a tolerância de plantas à estresse abiótico e com elevado potencial biotecnológico para aplicação na agricultura [Begcy et al., 2012]. A família de genes $S c S u S y$ tem papel fundamental para o processo de partição de carbono em plantas através do controle do nível de sacarose nas células [Zhang et al., 2013]. A família de genes ScPAL está envolvida com a biossíntese de fenilpropanóides e este grupo químico está relacionado indiretamente com a formação da parede celular de plantas [Ferreira et al., 2016].

O gene $S c d r 1$ e as famílias gênicas $S c S u S y$ e $S c P A L$ foram selecionados do projeto SUCEST-FUN (http://sucest-fun.org) através dos catálogos Sugarcane Signal Transduction Catalogue - SUCAST, Sugarcane Metabolism Catalogue - SUCAMET e Sugarcane Cell Wall Catalogue. Em seguida os genes $S c d r 1, S c S u S y$ e $S c P A L$ foram identificados no Genespace de cana-de-açúcar SP80-3280 (Souza, GM, et al 2018 - manuscrito em revisão, Zhang, J, et al 2018 - manuscrito aceito) através da busca por similaridade usando a ferramenta blast com cobertura e identidade superiores a $80 \%$ e e-value menor 1e-25. Após a busca por similaridade, nós recuperamos apenas a região do primeiro éxon de cada gene codificante de proteína anotado no Genespace de cana-de-açúcar SP80-3280. 


\subsubsection{Transcriptoma de cana-de-açúcar}

A seleção da região não codificante de cana-de-açúcar foi orientada por dados de expressão gênica em diferentes tecidos e condições experimentais. A identificação destes genes foi realizada através da análise de cinco transcriptomas obtidos de experimentos de RNAseq [Cardoso-Silva et al., 2014, Li et al., 2016, Nishiyama et al., 2014, Vicentini et al., 2015]. Embora cada transcriptoma utilize genótipos de cana-de-açúcar diferentes, todos apresentam potencial agronômico para diferentes condições edafoclimáticas [Cardoso-Silva et al., 2014, Li et al., 2016, Nishiyama et al., 2014, Vicentini et al., 2015].

O processo de seleção de genes, diferencialmente expressos ou co-expressos, foi realizado de acordo com [Trapnell et al., 2010]. Para cada um dos transcriptomas, o mapeamento das reads foi realizado no Genespace de SP80-3280 usando a ferramenta tophat2 [Trapnell et al., 2010] e a identificação dos genes diferencialmente ou co-expressos nós utilizamos as ferramentas samtools, cufflinks e R (pacote cummeRbund) [Trapnell et al., 2010]. A figura 2.1 resume o processo de análise do transcriptoma.
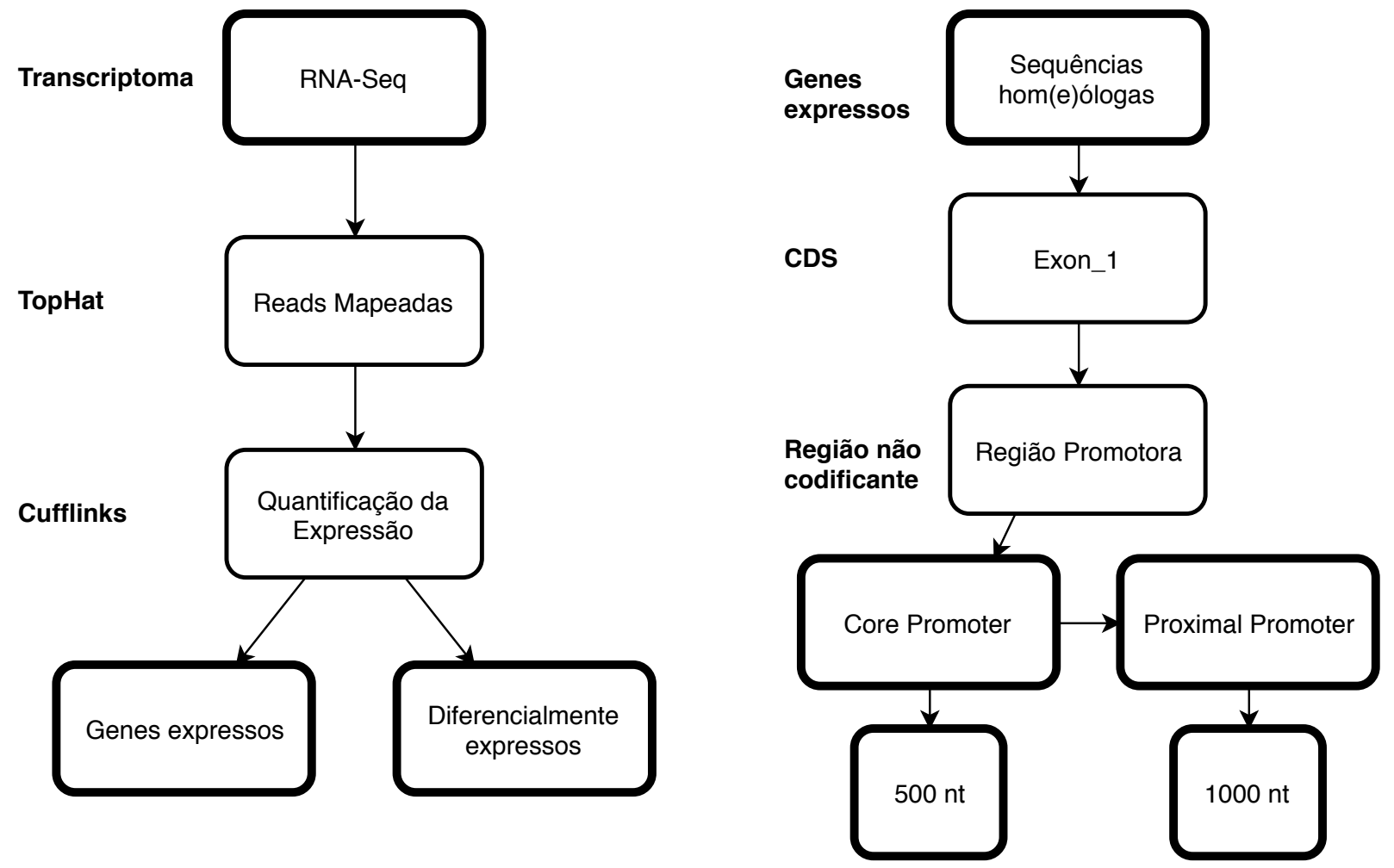

Figura 2.1: Esquema para caracterização da região da promotora através do transcriptoma. Cada sequência de DNA apresenta tamanho máximo de 1500 nt e foi extraída da região upstream de genes co-expressos. A análise foi realizada usando o genoma de referência (Genespace) de SP80-3280. 
Tabela 2.1: Quadro de informações para a seleção de genes co-expressos e sequências de TSS .

\begin{tabular}{|c|c|c|c|c|}
\hline Banco de Dados & Característica & Técnica & Objetivo & Site \\
\hline Sucest-fun & Transcriptoma & Microarranjo & Seleção de genes & sucest-fun.org \\
\hline NCBI/PubMed & Transcriptoma & RNA-Seq & Seleção de genes & ncbi.nlm.nih.gov \\
\hline NCBI/PubMed & Genômica & Transgênico & Seleção de genes & ncbi.nlm.nih.gov \\
\hline Ensembl & Região Promotora & Região não codificante. & Seleção Região Promotora & ensembl.org \\
\hline EPD & Região Promotora & TSS-seq & Local TSS & Epd.vital-it.ch \\
\hline RAP-DB & Região Promotora & fl-cDNA & Local TSS & rapdb.dna.affrc.go.jp \\
\hline
\end{tabular}

\subsection{Dados de sequências e de expressão de cana-de-açúcar}

\subsubsection{SUCEST-FUN}

O projeto SUCEST-FUN (http://sucest-fun.org) foi desenvolvido para identificar e organizar genes de cana-de-açúcar associados com rendimento de sacarose, quantidade de biomassa e resistência à seca. Este conjunto de gene está organizado em três principais catálogos - Sugarcane Signal Transduction Catalogue - SUCAST, Sugarcane Metabolism Catalogue - SUCAMET e, Sugarcane Cell Wall Catalogue [Ferreira et al., 2016, Lembke et al., 2012, Nishiyama et al., 2010]. Dessa forma, a identificação inicial dos genes $S c d r 1, S c S u S y$ e $S c P A L$ foi realizada no SUCEST-FUN através de informações de sequências expressas (EST/SAS). Em seguida estes genes foram identificados no Genespace de SP80-3280, assim como suas respectivas sequências homeólogas.

\subsubsection{RNA-Seq de cana de açúcar}

A identificação de genes co-expressos em cana-de-açúcar SP80-3280 foi realizada em cinco transcriptomas individualmente. Destes cinco transcriptomas, quatro são públicos e foram realizados com diferentes variedades de cana-de-açúcar [Cardoso-Silva et al., 2014, Li et al., 2016, Nishiyama et al., 2014, Vicentini et al., 2015]. O último transcriptoma foi realizada em plantas cana-de-açúcar SP80-3280 (dados não publicados - projeto FAPESP 2013/13659-0).

O primeiro transcriptoma foi obtido a partir de três plantas de cana-de-açúcar, entre elas a variedade comercial SP80-3280 e duas plantas ancestrais de cana-de-açúcar: Saccharum officinarum (Caiana listrada) e Saccharum spontaneum (IN8458) [Nishiyama et al., 2014].

O segundo conjunto foi obtido do transcriptoma de 6 variedades comerciais de canade-açúcar: IACSP96-3046, IACSP95-3018, SP81-3250, SP80-3280, RB925345 e RB835486. Estas plantas já foram utilizadas em diferentes grupos de melhoramento vegetal de cana-deaçúcar no Brasil e apresentaram resistência contrastante ao fitopatógeno Puccinia kuehnii [Cardoso-Silva et al., 2014].

O terceiro conjunto foi obtido a partir de duas variedades contrastantes para o conteúdo de lignina: IACSP04-065 com menor teor de lignina e IACSP04-627 com maior teor [Vicentini et al., 2015].

No quarto conjunto, os dados foram obtidos a partir de genótipos com a capacidade de 
abscisão foliar contrastantes durante o período de maturação das plantas de cana-de-açúcar. Para este ensaio, os autores usaram 6 genótipos: duas progenitoras i) ROC-26 planta precoce e com retenção de folhas durante a maturação; ii) GT96-167 planta tardia com abscisão foliar no início da maturação; e quatro plantas F1 do cruzamento entre estes progenitores foram selecionadas; duas apresentaram abscisão foliar no início da maturação e as outras duas apresentaram retenção foliar no início da maturação [Li et al., 2016]. Para mais detalhes de cada transcriptoma consulte as referências Cardoso-Silva et al. [2014], Li et al. [2016], Nishiyama et al. [2014], Vicentini et al. [2015].

O transcriptoma de cana-de-açúcar SP80-3280 foi realizado em plantas de cana-de-açúcar sob estresse hídrico. Este experimento foi conduzido pela doutora Danielle Izilda Rodrigues (dados não publicados - projeto FAPESP 2013/13659-0). Neste estudo utilizou-se plantas de cana-de-açúcar sob diferentes períodos de restrição hídrica: 4 dias sem irrigação, 6 dias sem irrigação e 6 dias sem irrigação seguidos por 2 dias com irrigação.

A partir desse experimento foi possível realizar duas avaliações: uma fisiológica e a outra do transcriptoma. Para o transcriptoma duas avaliações foram realizadas. A primeira foi realizada por meio de microarranjos já descritos no trabalho de Lembke et al. [2012] para os 3 tratamentos. Já a segunda avaliação foi realizada através do sequenciamento do mRNA para um único tratamento: 6 dias sem irrigação. A seleção dessa condição está relacionada aos resultados obtidos na avaliação fisiológica do experimento, uma vez que, foi neste período que houve a maior diferença entre os parâmetros fisiológicos avaliados.

Todo processo de extração de preparação do mRNA foi conduzido de acordo com os protocolos descritos em [Zeng and Yang, 2002]. Para esta etapa três amostras dos tecidos de Raiz e Folha de plantas com déficit hídrico foram utilizadas para extração do mRNA. O mesmo procedimento foi conduzido para o grupo de controle - plantas sem supressão hídrica (Danielle Izilda Rodrigues; FAPESP 2013/13659-0). Após a extração do mRNA, todo o material extraído foi avaliado quanto a qualidade usando o equipamento 2100 Bioanalyzer (Agilent Technologies). Ademais, o material foi armazenado e em seguida enviado para ser sequenciado (projeto FAPESP 2013/13659-0).

A seleção de genes co-expressos foi realizada em cada um dos transcriptomas de canade-açúcar anteriores. Essa seleção foi baseada nos dados de expressão dos genes homeólogos $S c d r 1, S c S u S y$ e $S c P A L$. Assim para cada gene avaliado nós isolamos 49 genes co-expressos em cada conjunto de RNA-Seq. A figura 2.2 apresenta o esquema de análise utilizado no processo. Após a identificação dos genes co-expressos nós recuperamos a sequência de DNA da região promotora destes genes no Genespace de cana-de-açúcar SP80-3280.

\subsection{Sequências de TSS}

O EPD (The Eukaryotic Promoter Database) é o principal repositório de sequências de DNA de região promotora de organismos superiores [Dreos et al., 2016]. No EPD diferentes 


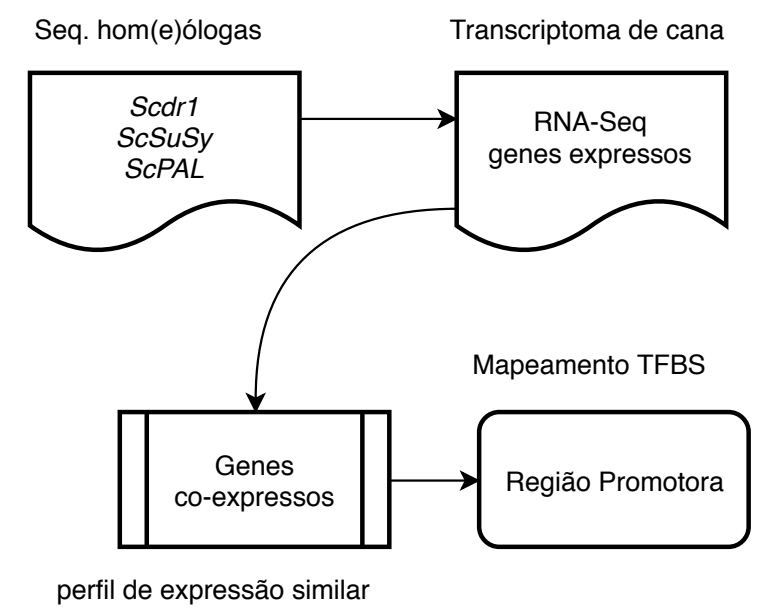

Figura 2.2: Esquema de análise da região promotora para os genes co-expressos. Para cada transcriptoma um grupo de genes co-expressos foi obtido através da seleção de genes com expressão similar aos genes $S c d r 1, S c S u S y$ e $S c P A L$. Em seguida a região upstream com 1500 nt foi extraída e caracterizada.

organismos, como Arabidopsis thaliana, Drosophila melanogaster, Saccharomyces cerevisiae e Homo sapiens, apresentam o sinal de TSS validado por diferentes experimentos in vivo. Estes TSSs foram curados usando diferentes tecidos usando técnicas como CAGE, PEAT, TSS-seq e GRO-cap [Dreos et al., 2016]. Outra característica importante relacionada ao EPD está na disponibilização pública dos seus dados e a constantemente atualização destas informações [Dreos et al., 2016]. A tabela 2.2 apresenta o total de promotores validados no EPD, assim como a versão dos dados depositados no banco.

O EPD tem disponibilizado a localização do sinal de TSS com elevada precisão [Dreos et al., 2016]. Na versão anterior do EDP (vr. 2013) $40 \%$ e $70 \%$ dos genes de D. melanogaster e H. sapiens tinham o sinal de TSS validado. Na versão atual (vr. 2017) estes valores foram elevados para mais de $90 \%$ nos dois casos. Esse avanço está associado com a incorporação de novas informações oriundas de diferentes experimentos de descoberta in vivo do sinal de TSS gerados nos últimos anos [Dreos et al., 2016].

Portanto, o EPD é a principal referência para localização do sinal de TSS para os organismos não modelo. Por conseguinte a disponibilidade dos seus dados são fundamentais para a geração de novas ferramentas que buscam realizar a predição in silico da região promotora sem a necessidade de realizar inúmeros experimentos de descoberta in vivo do TSS.

\subsection{Workflow para identificação da região Promotora}

Neste trabalho nós consideramos apenas a região Promotora de genes codificantes de proteína. Para cada região Promotora putativa de cana-de-açúcar nós selecionamos uma sequência de nucleotídeos com tamanho máximo de 1500 nt à montante do sítio de início do gene predito em cana-de-açúcar. Da sequência de DNA isolada, a subsequência inicial

\footnotetext{
${ }^{1}$ Modificado do banco de dados EDP [Dreos et al., 2016].
} 
Tabela 2.2: Total de sequências de DNA da região promotora em diferentes organismos com localização do sinal de TSS validado por experimentos biológicos ${ }^{1}$

\begin{tabular}{|c|c|c|c|}
\hline Organismos & Genes & Região Promotora (No TSS) & Vesão \\
\hline H. sapiens & 16.455 & 29.598 & 6 \\
\hline M. mulatta & 9.026 & 9.575 & 1 \\
\hline M. musculus & 20.213 & 25.111 & 3 \\
\hline R. norvegicus & 12.013 & 12.601 & 1 \\
\hline C. familiaris & 7.321 & 7.545 & 1 \\
\hline G. gallus & 5.632 & 6.127 & 1 \\
\hline D. melanogaster & 13.399 & 16.972 & 5 \\
\hline A. mellifera & 5.712 & 6.493 & 1 \\
\hline D. rerio & 10.235 & 10.728 & 1 \\
\hline C. elegans & 6.363 & 7.120 & 1 \\
\hline A. thaliana & 22.703 & 22.701 & 4 \\
\hline Z. mays & 15.828 & 17.081 & 1 \\
\hline S. cerevisiae & 5.117 & 5.117 & 2 \\
\hline S. pombe & 4.801 & 4.802 & \\
\hline
\end{tabular}

com tamanho máximo de 500 nt foi considerada como a região central da região Promotora (Core Promoter) e a subsequência de 1000 nt à montante do Core Promoter foi considerada como a região Promotora Proximal da região Promotora. A identificação in silico de TFBS foi realizada na região Promotora Proximal.

Na região Core Promoter nós realizamos a identificação do sinal TSS, a estimativa do tamanho região 5'UTR e a classificação dessa região em TATA-box, TATA-less e região Promotora não identificada. Para a rotulação da região Core Promoter, nós utilizamos a ferramenta TSSPlant. Essa ferramenta foi desenvolvida especificamente para caracterização da região Core Promoter de plantas Dicotiledôneas e Monocotiledôneas [Shahmuradov et al., 2017].

Na região Promotora proximal nós realizamos a predição de novo de TFBS através de duas ferramentas: MEME-Suite [Bailey et al., 2009] e Motif-Suite [Claeys et al., 2012]. As duas ferramentas apresentam estratégias de identificação de TFBSs diferentes: i) MEMESuite metodologia determinística - Maximização da Expectativa; ii) Motif-Suite metodologia estocástica - Gibbs sampler.

A principal motivação para o uso destes modelos é ampliar a capacidade de descoberta de TFBS uma vez que o processo de identificação através destas duas metodologias podem ser complementares. Em geral a utilização paralela destes modelos aumentam a confiabilidade do processo de predição de novo além de auxiliar na descoberta de TFBS não descritos na literatura.

Por último, todos TFBSs preditos de novo foram mapeados com a ferramenta Moti- 
fLocator [Claeys et al., 2012] nas sequências de DNA que não participaram do processo de predição de novo. O mapeamento foi realizado nos genes $S c d r 1, S c S u S y, S c P A L$ e nos genes co-expressos em cana-de-açúcar SP80-3280.

\subsubsection{Análise da região Core Promoter}

A classificação quanto a anotação da região Core Promoter foram obtidas pela ferramenta TSSPlant. A figura 2.3 apresenta o fluxo de trabalho da análise. Após a identificação do sinal de TSS, todas as sequências de DNA foram classificadas em TATA-box e TATA-less. Dessa forma, o processo de classificação foi realizado com o objetivo de identificar a presença ou ausência do motivo TATA-box. Em cada sequência analisada, a classificação TATA-box foi atribuída somente para as sequências de DNA que apresentavam o sítio TATA-box. Caso contrário, a classificação atribuída foi TATA-less. Ademais, para todas as sequências de DNA que não apresentaram a identificação do sítio de TSS, estas sequências não foram atribuídas a classificação de região Promotora.

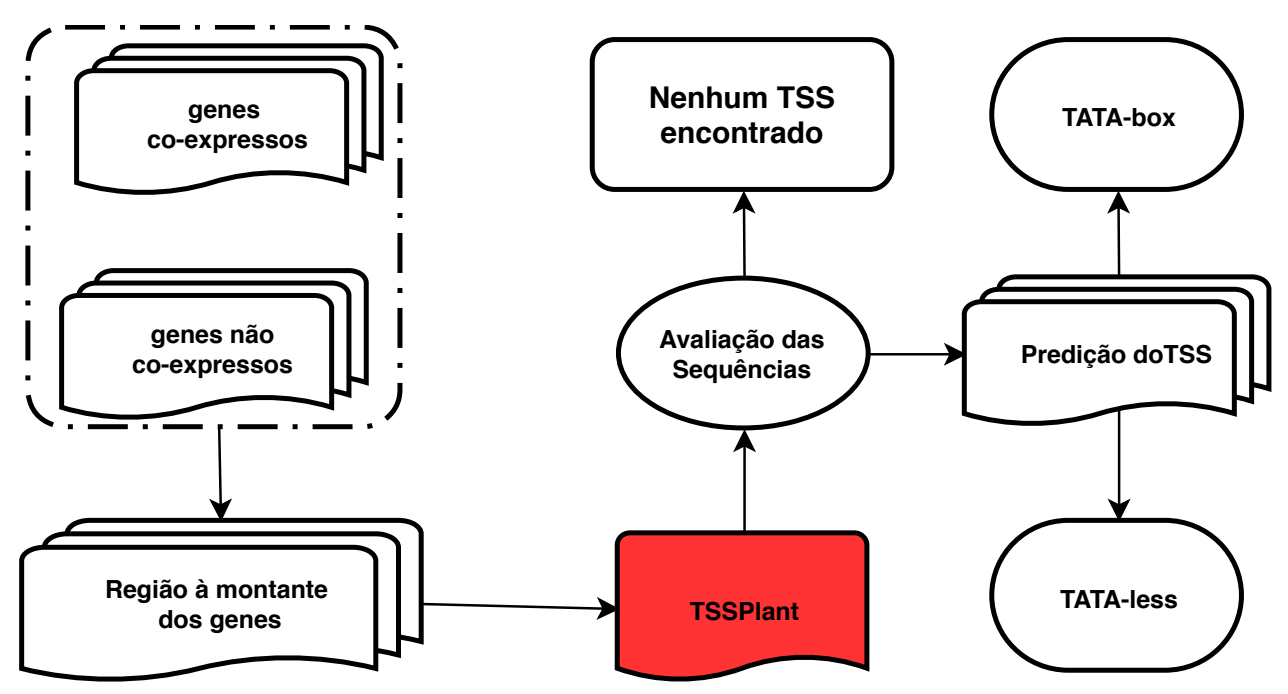

Figura 2.3: Fluxograma para caracterização da região Core Promoter. Cada sequência de DNA apresenta tamanho máximo de 500 nt e foi extraída da região upstream de genes co-expressos ou não. A etapa em destaque representa o momento que a ferramenta TSSPlant foi utilizada para caracterizar a região Promotora.

\subsubsection{Análise da região Promotora Proximal}

Na região Promotor Proximal a análise foi realizada em 2 duas etapas: Predição de novo de TFBS - procedimento realizado apenas no subconjunto de sequências de DNA dos genes $S c d r 1, S c S u S y$ e $S c P A L$ - e mapeamento dos TFBSs preditos de novo - procedimento realizado em todas as sequências de DNA da região Promotora Proximal que não participaram do procedimento de predição de novo, além de todas as sequências de DNA da região Promotora Proximal dos genes co-expressos. 
No processo de predição de novo as matrizes de pesos por posição (Position Weight Matrices - PWM) foram geradas através da execução de dois algoritmos: Máxima Expectativa e Gibss Sampling. Estes algoritmos estão implementados nas ferramentas MEME e MotifSampler, respectivamente [Bailey et al., 2009, Claeys et al., 2012]. Para as duas ferramentas, a procura dos TFBS foi configurada para buscar no máximo 6 TFBSs diferentes, com tamanhos variando de 8 nt, 10 nt, 12 nt e 15 nt. Para cada grupo de TFBS identificado, isso independente da ferramenta utilizada, nós selecionamos apenas os cinco TFBSs com maior score ou TFBSs que estavam acima do cut-off determinado pela ferramenta; em geral o cut-off usado nas análises foi padrão.

Após a seleção dos TFBSs preditos com maior score, nós realizamos a busca por similaridade entre os TFBSs preditos e os TFBSs já descritos na literatura e depositados no banco de dados JASPAR core plants [Khan et al., 2017]. Nessa tarefa nós utilizamos a ferramenta TOMTOM com configuração padrão [Bailey et al., 2009].

Na etapa de mapeamento a avaliação da significância dos TFBSs preditos foi realizada através da comparação entre as frequências destes TFBSs na sequência de DNA da região Promotora Proximal dos genes co-expressos com a região Promotora Proximal dos genes que não apresentavam co-expressão. Todos os TFBSs selecionados foram mapeados com a ferramenta MotifLocator [Claeys et al., 2012]. O modelo de background utilizado nas análises foi obtido de sequências de DNA codificante de proteínas em cana-de-açúcar. Esse modelo foi criado usando Cadeias de Markov de primeira ordem e cada sequência de nucleotídeo utilizada na construção do modelo de background foi embaralhada previamente.

Nós recuperamos, em ambos conjuntos de genes co-expresso ou não co-expressos, apenas os TFBSs com alinhamento completo e com score acima de 95\% em relação ao modelo de background. A figura 2.4 apresenta o fluxo de trabalho para a análise da região Promotora Proximal.

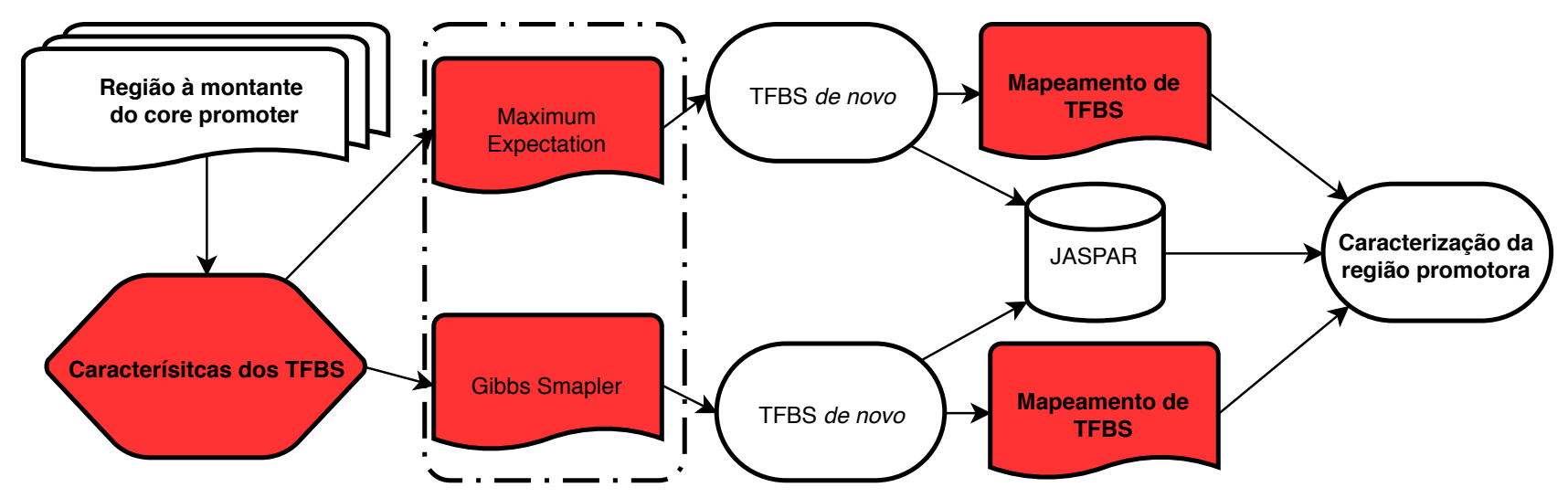

Figura 2.4: Fluxograma para caracterização da região Promotora Proximal Ferramentas utilizadas no fluxo de trabalho: MEME, MotifSampler, MotifLocator e TOMTOM. 


\subsection{TSSFinder - Predição ab initio do sinal de TSS}

\subsubsection{Modelagem probabilística Linear-chain CRF}

O TSSFinder foi desenvolvido para caracterizar a região Core Promoter através identificação do sinal de TSS. O processo de caracterização realizado pelo TSSFinder pode ser executado tanto em promotores com arquitetura TATA-box quanto em promotores TATAless. A figura 2.5 é a representação gráfica do processo de modelagem que foi utilizado no TSSFinder para identificar o sinal de TSS em diferentes organismos.

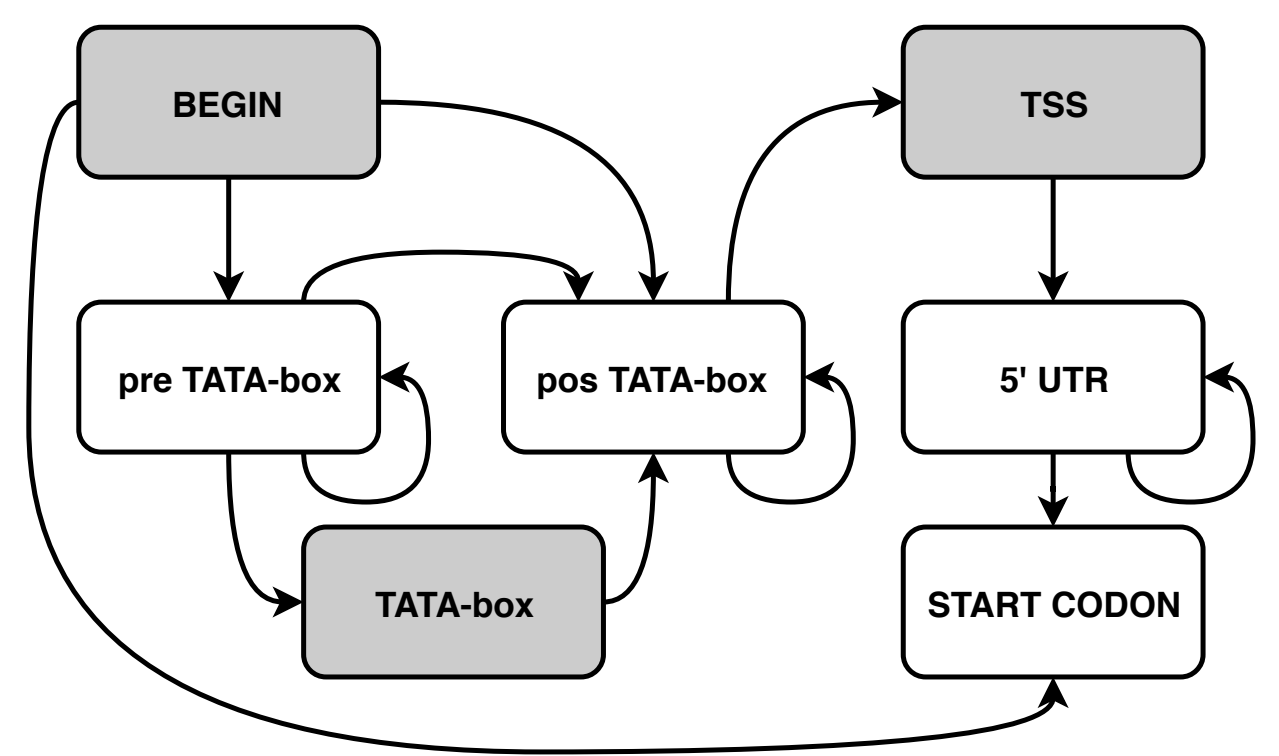

Figura 2.5: Máquina de estados representado as características da modelagem utilizada pelo TSSFinder para o problema de identificação do sinal de TSS

$\mathrm{Na}$ figura cada retângulo representa um sinal (estado) capturado pelo modelo e cada seta representa o processo de transição entre os estados modelados pelo TSSFinder. Os principais sinais utilizados na modelagem do problema estão representados pelos retângulos em destaque. Início - sinal para determinar o tamanho da sequência de DNA; TATA-box - sinal que determina o sítio de TATA-box; TSS - sinal que determina a localização do sítio de TSS. Além destes, outros três sinais são utilizados na modelagem do problema. 5 ' UTR sinal para determinar a sequência de DNA não traduzida no mRNA entre o start códon e sítio de TSS; pré/pós TATA-box - sinais para determinar a sequência de DNA ao redor do sinal de TATA-box além da modelagem da sequência de DNA com o sinal de TATA-box ausente. O retângulo ATG representa o sinal para o início de tradução do gene.

O TSSFinder é baseado no modelo probabilístico discriminativo Campos Aleatórios Condicionais de Cadeias Lineares (Linear Chain-CRF) [Lafferty et al., 2001]. A modelagem do TSSFinder apresenta características similares aos modelos gerados (modelos de Cadeias Ocultas de Markov - HMM) uma vez que a determinação dos estados é obtida através de um conjunto de sequências observadas. Para esse processo de rotulação o TSSFinder usa a probabilidade condicional $P(y \mid x)$ onde a rotulação do estado oculto $y$ é alcançada através da observação de uma dada sequência $x$ (2.1). 


$$
P(y \mid x)=\frac{1}{Z(x)} \exp \left\{\sum_{t=1}^{T} \sum_{k=1}^{K} \lambda_{k} f_{k}\left(y_{t}, y_{t-1}, x\right)\right\},
$$

Onde $T$ é tamanho das sequências, $K$ é o número de características usadas no modelo, $f_{k}$ é a função de características, $\lambda_{k}$ é o parâmetro de aprendizado do modelo e $Z(x)$ é o fator de normalização $(2.2)$.

$$
Z(x)=\sum_{y} \exp \left\{\sum_{t=1}^{T} \sum_{k=1}^{K} \lambda_{k} f_{k}\left(y_{t}, y_{t-1}, x\right)\right\}
$$

De acordo com nossa modelagem de predição do sinal de TSS, a sequência de observação $x$ é uma sequência de nucleotídeos onde o último símbolo é uma adenina (A) e este nucleotídeo é pertencente ao sítio de início da transcrição. Com isso o objetivo do modelo é encontrar uma sequências de rótulos $y$ tal que $P(y \mid x)$ seja máxima. Os rótulos $y$ estão definidos nos estados representados na figura 2.5.

O modelo apresenta dois tipos de características básicas: bigramas e unigramas. Os bigramas representam a transição entre os rótulos e os unigramas representam os processos de transição na máquina de estado observada na figura 2.5. Cada unigrama representa a possibilidade de um estado ser o rótulo de uma observação e as características do unigrama são definidas da seguinte maneira: $1_{\left\{x_{i-a}=N\right\}} 1_{\left\{x_{i-b}=N^{\prime}\right\}}$ para todo $a \neq b, 0 \leq a \leq 3,0 \leq b \leq 3 \mathrm{e}$ $N, N^{\prime} \in\{A, C, G, T\}$ onde a função $1_{\{c o n d\}}$ é 1 quando cond é verdadeira ou 0 caso contrário.

A precisão do modelo é alcançada através das funções de características unigrama baseada na distribuição da distância entre um sinal e o seu predecessor (2.3). Essas funções podem ser definidas da seguinte maneira:

$$
f d_{D}\left(y_{t}, y_{t-1}, x\right)= \begin{cases}1 & \text { se } D-50 \leq T-t \leq D \\ 0 & \text { caso contrário }\end{cases}
$$

Para todos $50 \leq d \leq 600$ que é múltiplo de 50. Por fim, o parâmetro $\lambda_{k}$ (processo que controla a aprendizado da máquina) é obtido através da função de maximização da probabilidade (2.4) e esta função foi descrita anteriormente pelo método de otimização LBFGS (Limited-memory Broyden-Fletcher-Goldfarb-Shanno) [Lafferty et al., 2001]:

$$
l(\theta)=\sum_{i=1}^{N} \sum_{t=1}^{T} \sum_{k=1}^{K} \lambda_{k} f_{k}\left(y_{t}^{(i)}, y_{t-1}^{(i)}, x^{(i)}\right)-\sum_{i=1}^{N} \log Z\left(x^{(i)}\right)-\sum_{t=1}^{T} \sum_{k=1}^{K_{t}} \frac{\lambda_{k}^{2}}{2 \sigma^{2}}
$$

\subsubsection{Validação da ferramenta TSSFinder}

Como descrito anteriormente, o processo de validação da ferramenta TSSFinder foi realizado dividindo o conjunto total de sequências de cada organismo em 5 subgrupos com número final de sequências igual entre eles. Assim para $A$. thaliana cada subgrupo ficou com 3.924 sequências; D. melanogaster com 2.950; G. gallus com 1119; H. sapiens com 4.248; 
S. cerevisiae com 937 e S. pombe com 926. O tempo de treinamento necessário para cada subgrupo de sequências foi elevado e por esta razão nós utilizarmos apenas 1 subgrupo para treinar a ferramenta TSSFinder ao invés de 4 subgrupos. E consequentemente nós usamos 4 subgrupos para testar o modelo ao invés de apenas 1 subgrupo. Este processo de validação é uma variação do metodologia de aprendizado cross-validation usando a técnica k-fold. Apesar do cenário de validação ser mais rigoroso, o processo de validação da ferramenta TSSFinder não foi prejudicado.

Em paralelo nós realizamos o mesmo procedimento de validação anterior, entretanto, nós utilizamos dados de cDNA full-length. Essa análise foi executada para verificar a capacidade do TSSFinder em lidar com dados mais próximos da realidade da maioria dos organismos não modelo. Por esta razão nós utilizamos apenas dados de $O$. Sativa e a validação do TSSFinder foi executada em duas etapas de análise: i) realizada em 5 subgrupos e cada subgrupo tinha 9.108 sequências; ii) realizada através da seleção de um subgrupo com 9108 sequências e em seguida este conjunto de sequências foi dividido em duas partes iguais e cada parte gerada foi dividida pela metade e assim sucessivamente. Dessa forma foi possível criar 5 subgrupos sequências e cada grupo apresentou os seguintes tamanhos: 4554, 2277, 1139, 570 e 285 sequências.

Para validação do TSSFinder treinado com estes conjuntos, nós executamos o modelo treinado em todas sequências de DNA remanescentes que não participaram do processo de treinamento. Esse último procedimento foi realizado para verificar o tamanho mínimo necessário para o treinamento do TSSFinder sem prejudicar o processo predição. Tanto no primeiro grupo de análises quanto no segundo grupo, a predição do TSSFinder foi considerada verdadeira se o sinal identificado pela ferramenta estava próximo a 100 nt do local real do sinal TSS.

\subsubsection{Comparação do TSSFinder com outras ferramentas}

O TSSFinder foi avaliado contra duas ferramentas de predição da região Core Promoter: TIPR [Morton et al., 2015] e TSSPlant [Shahmuradov et al., 2017]. O teste foi realizado com 3.564 sequências de DNA da região promotora de $A$. Thaliana.

Cada ferramenta foi avaliada de acordo com as instruções dos seus autores e adicionalmente nas condições dos seus pares. Portanto para ferramenta TIPR o mecanismo de avaliação foi executado usando sequências de DNA com 10.001 nt. Nestas sequências o sinal de TSS estava localizado na posição 5001 da sequência de DNA. Na ferramenta TSSPlant o processo de análise foi realizado em sequências de 1101 nt com 100 nt a jusante do sinal de TSS e 1000 nt à montante do sinal de TSS. Finalmente, o TSSFinder foi treinado usando sequências de DNA com os tamanhos 1500 nt e a avaliação foi realizada com 2000 nt à montante do start codon, respectivamente.

Nessa avaliação nós usamos as ferramentas TIPR e TSSPlant nas versões disponíveis pelos seus desenvolvedores uma vez que estas ferramentas não permitem que o usuário fi- 

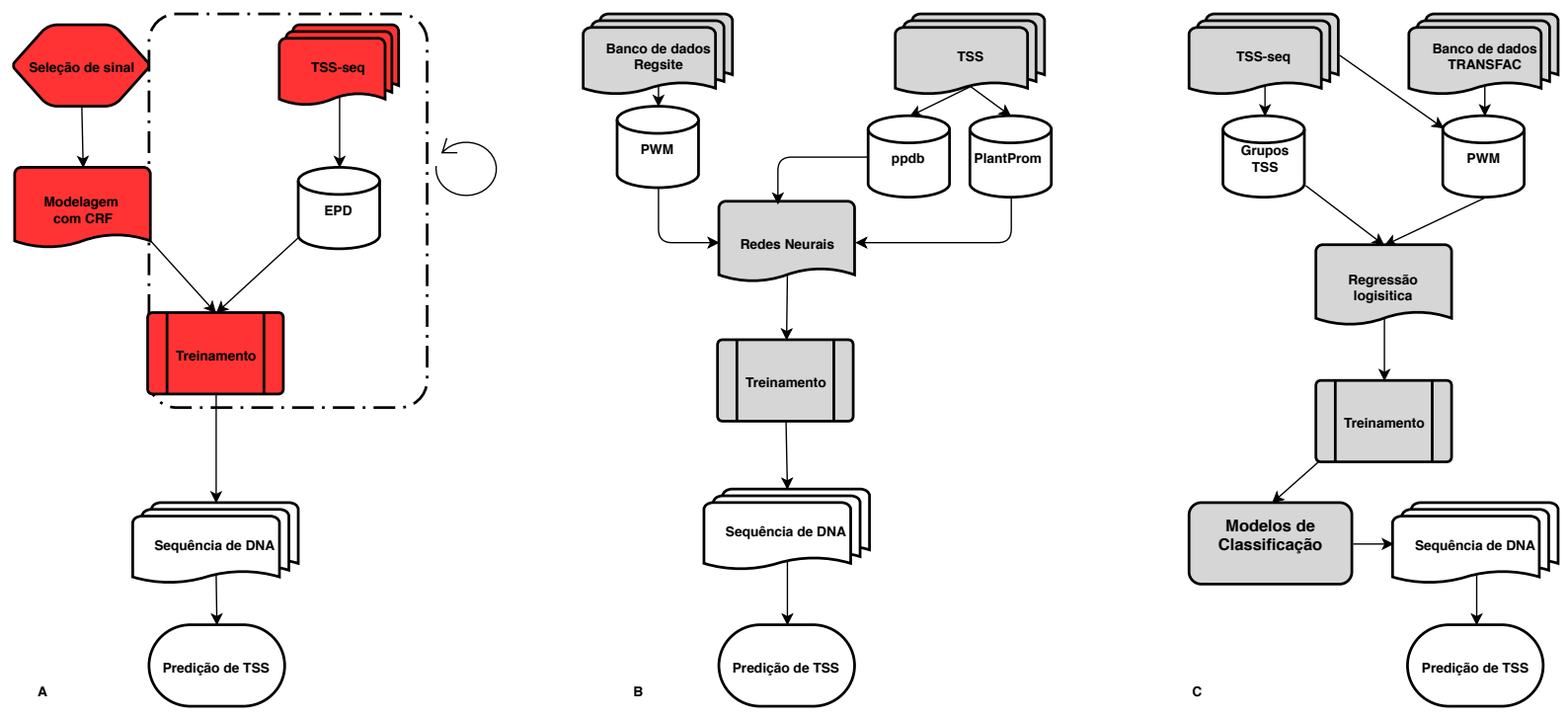

Figura 2.6: Fluxograma de trabalho para predição do sinal de TSS Figuras: A) TSSFinder B) TSSPlant C) TIPR. O esquema resume as etapas de treinamento e predição nos três modelos.

nal utilize seu próprio conjunto de treinamento. Ambas as ferramentas foram treinadas com sequências de DNA da região promotora de $A$. Thaliana sendo que a ferramenta TIPR é uma versão não publicada (comunicação pessoal) e TSSPlant versão standalone [Shahmuradov et al., 2017]. O TSSFinder foi treinado usando 3.924 sequências de DNA de A. Thaliana que estavam ausentes do conjunto de teste. Todas 3.924 sequências de DNA foram selecionadas randomicamente do banco de dados EPD [Dreos et al., 2016]. 


\section{Capítulo 3}

\section{Objetivos}

- Análise de regiões regulatórias em cana-de-açúcar

- Identificação e análise de TSS

- Classificação da região do Core Promoter

- Estimativa de tamanho da 5’UTR

- Predição de TFBS na região Promotora Proximal

- Desenvolvimento de workflow utilizando as metodologias para análise de TSS, Core Promoter, UTR 5' e predição de TFBS

- Aplicação da metodologia em genes de interesse de cana-de-açúcar

- Definição do conjunto de genes de interesse utilizando-se dados de transcriptoma

- Análise da arquitetura dos promotores de grupo para genes

- Comparação das arquiteturas de genes de famílias multi-gênicas (homeólogos)

- Identificar os TFBS na região Promotora Proximal (Predição de novo de TFBS e mapeamento dos TFBS).

- Desenvolvimento de uma nova ferramenta para predição ab initio de TSS 


\section{Capítulo 4}

\section{Resultados}

A apresentação deste capítulo será organizada em duas etapas:

- apresentação dos resultados da análise in silico da região Promotora em cana-deaçúcar;

- apresentação dos resultados do desenvolvimento da ferramenta para TSSFinder.

\subsection{Análise in silico da região Promotora de cana-de- açúcar}

Todas as análises da região promotora de cana-de-açúcar foram executadas apenas nas sequências de DNA do Genespace da variedade SP80-3280 (Souza, GM, et al 2018 - manuscrito em revisão, Zhang, J, et al 2018 - manuscrito aceito). Os resultados estão organizados da seguinte maneira:

- Caracterização da região Core Promoter dos genes Sugarcane drought-responsive 1 (Scdr1), Sucrose Synthase (ScSuSy) e phenylalanine ammonia-lyase (ScPAL).

- Rotulação da região Promotora Proximal através da predição de TFBS de novo genes Scdr1, ScSuSy e ScPAL.

- Identificação dos genes homeólogos $S c d r 1, S c S u S y$ e $S c P A L$ expressos no Transcriptoma de cana-de-açúcar.

- Identificação de genes co-expressos com os genes homeólogos $S c d r 1, S c S u S y$ e $S c P A L$ no Transcriptoma de cana-de-açúcar.

- Análise da região Promotora de genes co-expressos com os genes homeólogos Scdr1, $S c S u S y$ e $S c P A L$.

Para os genes co-expressos a análise da região Core Promoter foi semelhante aos genes $S c d r 1, S c S u S y$ e $S c P A L$. Entretanto, na região Promotora Proximal não foi realizada 
a predição de novo de TFBS, apenas o mapeamento dos TFBSs preditos nos genes Scdr1, ScSuSy e ScPAL.

\subsubsection{Caracterização do Core Promoter dos genes homeólogos Scdr1}

No Genespace de SP80-3280 foi possível identificar 13 sequências homeólogas à sequência de DNA codificante do gene $S c d r 1$. A partir desse conjunto de sequências, nós isolamos a região Promotora de cada sequência limitando o tamanho em até 1500 nt de distância em relação ao início da região codificante.

Em todas sequências da região Promotora do gene $S c d r 1$ foi possível identificar o sinal de TSS. A partir da identificação do TSS foi possível estimar o tamanho da região 5' UTR em 220 nt. Também associado ao sinal de TSS, 7 sequências da região Promotora do gene Scdr1 foram classificadas como TATA-less e o restante classificada como TATA-box.

\subsubsection{Rotulação do Promotor Proximal dos genes homeólogos Scdr1}

A predição de todos TFBSs foi similar entre os dois métodos: Maximização da expectativa e Gibbs sampler. Apesar da variação na largura do TFBS imposta no início do procedimento - de 5 até 15 nt, todos os TFBSs identificados apresentaram tamanho de nucleotídeos uniforme: 15 nt. Foi possível identificar 6 TFBSs diferentes: Myb, NAC, WRKY e AP2/ERF [Khan et al., 2017]. Entretanto, apenas no método de Maximização da expectativa o TFBS associados com o TF WRKY foi identificado [Khan et al., 2017].

Após a predição dos TFBSs foi realizada a associação destes sítios com algum TF responsivo ao estresse hídrico. Dentre as associações TF-TFBS realizadas foi possível identificar TFs com os domínios NAC (GGCCACGAAACAGCC) e Myb (AAGGACTGGAGCTGC) - ambos com apenas 1 TFBS predito, e TFs com os domínios AP2/ERF (CAGAGCTCGCCG[TC] CC, CGCGGCCGCGGCGTC) e WRKY (AAGGAACGCCGATGC, CCGTGGCCAAGGT CC) - ambos com dois TFBSs [Khan et al., 2017]. Ademais das 13 sequências analisadas apenas 6 apresentaram arquitetura de TFBSs associados ao mesmo conjunto de TFs - AP2/ERF, WRKY e NAC [Khan et al., 2017]. Nesse subconjunto de sequências foi possível observar o agrupamento de TFBSs na mesma região genômica e cada TFBS apresentou espaçamento entre si de até 35 nt. A figura 4.1 ilustra a organização da região Promotora para 13 sequências recuperadas do Genespace de cana-de-açúcar SP80-3280.

\subsubsection{Caracterização do Core Promoter dos genes homeólogos Sc- SuSy}

O gene ScSuSy em cana-de-açúcar SP80-3280 apresentou 44 sequências de DNA homeólogas ao gene SuSy de Sorgo (Souza, GM, et al 2018 - manuscrito em revisão). Além disso, estes genes foram distribuídos em 5 grupos e esta observação foi semelhante ao encontrado 


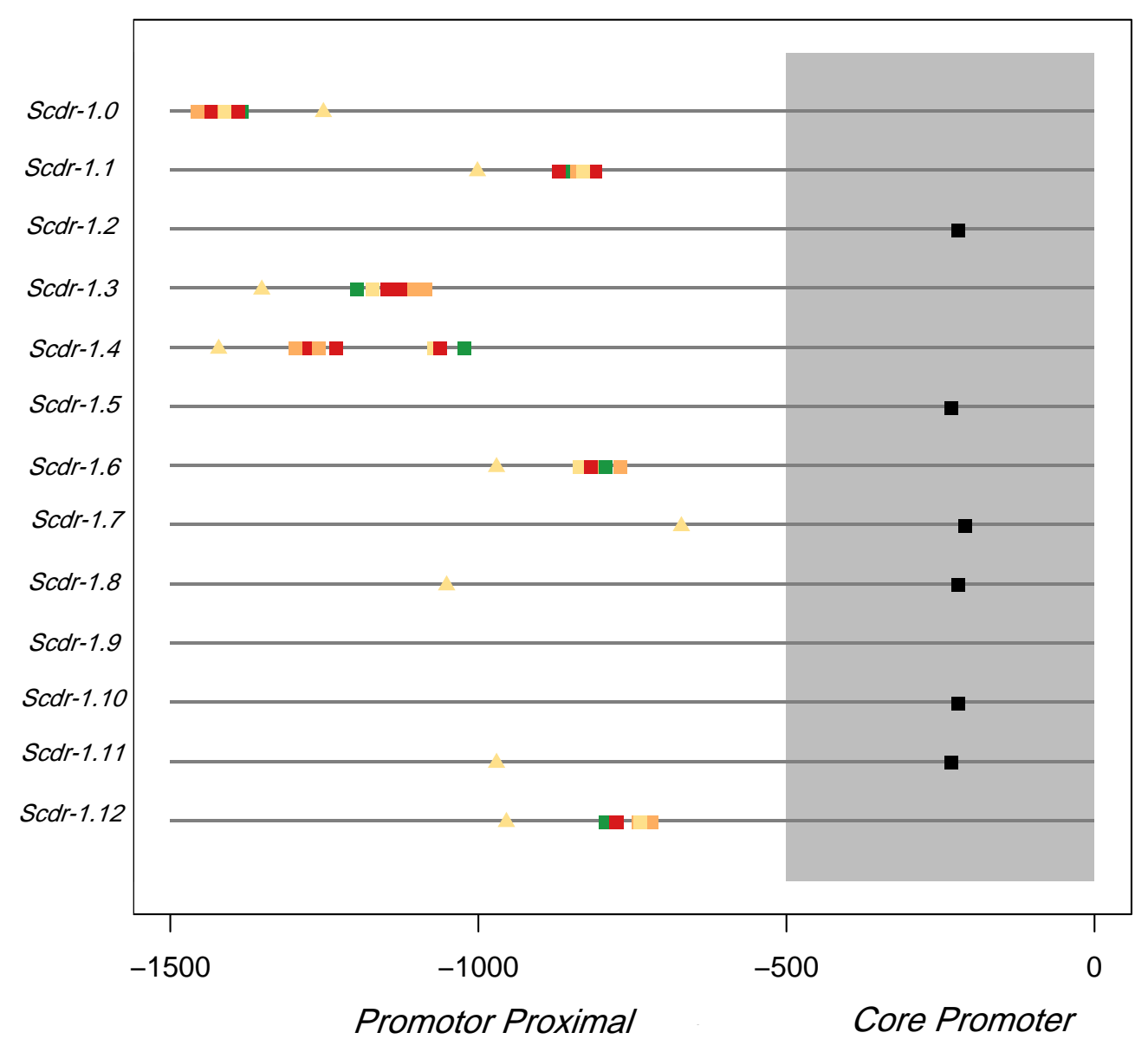

Figura 4.1: Região Promotora dos genes ScSdr1 A caracterização da região Promotora foi realizada através da classificação da região Core Promoter (linha horizontal preta dentro do retângulo cinza) e do mapeamento dos TFBSs na região Promotora Proximal (linha horizontal preta). Os TFBSs identificados foram representados pelas cores amarelo (triângulo - Myb), verde (NAC), vermelho (WRKY) e amarelo/laranja (AP2/ERF). Retangulo preto na área cinza representa o sinal de TATA-box.

em plantas de Sorgo [Zhang et al., 2013]. Entretanto o número de sequências homeólogas de cada grupo foi diferente. No grupo ScSuSy1 o número de sequências foi 9, no grupo ScSuSy2 foram 10 sequências, no grupo ScSuSy3 foram 13, no grupo ScSuSy4 foram 5 e o grupo ScSuSy5 foram 7 sequências. Por esta razão cada da sequência de DNA homeóloga teve a região Promotora recuperada e analisada separadamente.

Inicialmente, a região Promotora foi classificada em TATA-box, TATA-less e região não Promotora. Nessa tarefa, nós realizamos a rotulação da região Core Promoter através da 
ferramenta TSSPlant usando sequências de DNA com tamanho não superior a 500 nt de distância do início do gene anotado. Nessa análise foi possível classificar 21 sequências TATAbox, 15 TATA-less e 8 sequências sem nenhuma classificação (região não Promotora). Nas sequências não classificadas, o tamanho total observado para cada sequência foi inferior a 140 nt e por isso não foi possível identificar o sinal de TSS.

Em geral todos os grupos do gene ScSuSy apresentaram pelo menos uma sequência de DNA com sinal de TSS não identificado. Os grupos ScSuSy1 e ScSuSy3 apresentaram o maior número de sequências não classificadas; três e duas respectivamente. Curiosamente estes mesmos grupos de genes apresentaram o maior número de sequências homeólogas: ScSuSy1 com 9 sequências e ScSuSy3 com 13 sequências.

Nas sequências que foram rotuladas como região Promotora, independente da classificação atribuída, o tamanho médio da região 5' UTR foi de 180 nt. Este resultado pode ser um indicativo que o tamanho da região 5' UTR para genes ScSuSy, em cana-de-açúcar SP80-3280, é superior a 140 nt.

De acordo com os nossos resultados a classe TATA-box foi mais predominante nos grupos ScSuSy3 e ScSuSy5 e a classe TATA-less nos grupos ScSuSy2 e ScSuSy4. No grupo ScSuSy1 a classificação da região Promotora foi mais heterogênea, uma vez que 4 foram classificadas como TATA-box, 2 como TATA-less e 3 não foram rotuladas como região Promotora.

\subsubsection{Rotulação do Promotor Proximal dos genes homeólogos Sc- SuSy}

Após a avaliação da região Core Promoter, nós realizamos a rotulação da região Promotora Proximal através do processo de predição de novo de TFBSs. Esse processo foi realizado somente nas sequências de DNA que apresentaram o rótulo de região Promotora. A identificação dos TFBSs foi realizada nas sequências de DNA com tamanho não superior a 1000 nt de distância da região Core Promoter.

Todo processo de predição de novo foi realizado em cada grupo de genes $S c S u S y$ separadamente. Dessa forma a análise dos genes $S c S u S y$ foi realizada em cinco processos de predição de TFBS independentes. Seguida a identificação dos TFBSs, nós realizamos o mapeamento do TFBS predito na etapa anterior em todas as sequências de DNA que não participaram do processo de predição de novo. O processo de rotulação da região Promotora Proximal foi realizado pela identificação de novo de TFBS e pelo mapeamento destes TFBSs preditos em todas as sequências de DNA dos genes $S c S u S y$ e $S c P A L$ que participaram do processo de predição de novo.

A tabela 4.1 apresenta todos os TFBSs identificados para cada grupo de genes $S c S u S y$. Independente do método de descoberta - Maximização da expectativa ou Gibbs Sampler nós identificamos para cada grupo de gene $S c S u S y$ pelo menos 1 TFBS. Considerando todos os grupos, nós identificamos 12 TFBS e alguns destes TFBSs foram identificados nos dois métodos de predição de novo. Esse resultado indica que os TFBSs identificados na nossa 
análise podem estar exercendo alguma atividade regulatória e assim podemos classificar como sequências de DNA regulatórias putativas em cana-de-açúcar.

$\mathrm{Na}$ etapa seguinte, nós escolhemos apenas um único representante de TFBS em cada grupo de gene ScSuSy. Essa seleção foi orientada de acordo com a sobreposição de descoberta do TFBS entre os dois métodos de análise e o valor de pontuação atribuído a cada matriz que descreve o TFBS.

Assim para o grupo de genes ScSuSy1, nós selecionamos o TFBS wATATATATw. A sequência consenso deste TFBS foi associada com o elemento RVE1 [Khan et al., 2017, Rawat et al., 2009]. No geral, esse TFBS pode interagir com Fatores de Transcrição da fase matinal, além de atuar na integração de redes de regulação do relógio circadiano com os genes da via de sinalização do fitohormônio Auxina [Khan et al., 2017, Rawat et al., 2009]. No grupo ScSuSy2 nós selecionamos o TFBS associado ao elemento IDD7 [Cui et al., 2013, Khan et al., 2017]. A sequência consenso atribuída a este TFBS foi GACrAATryA e esta sequência pode apresentar associação com TFs responsáveis pela modulação do transporte e do metabolismo de açúcar [Cui et al., 2013, Khan et al., 2017]. Diferentes dos seus pares, o grupo ScSuSy3 apresentou apenas um único TFBS e sua matriz é descrita com a sequência consenso AyACTAGTrT. De acordo com a anotação do banco de TFBS JASPAR esta sequência foi associada com elementos responsivos ao fitohormônio ABA (ABRE) [Kang et al., 2002, Khan et al., 2017]. No geral estes elementos regulam genes da via de sinalização ABA. Para o grupo ScSuSy4, nós selecionamos o TFBS TAGyAynTTT. Aparentemente este TFBS está relacionado com regulação de genes do fotoperíodo [Khan et al., 2017, Pouteau et al., 2008]. Por fim, o grupo ScSuSy5 foi o único grupo de genes ScSuSy que apresentou TFBS com sequência consenso conservada: CTGCTAGCAG. Além disso, este TFBS foi relacionado com elemento ABI3 [Delmas et al., 2013, Khan et al., 2017] e este TFBS pode ser capaz de regular genes envolvidos na via de sinalização ABA [Delmas et al., 2013, Khan et al., 2017].

Tabela 4.1: Resultado da predição de novo de TFBS na familia de genes ScSuSy.

\begin{tabular}{lcccc}
\hline & Sequêcica consenso & ID Jaspar & Nome do TFBS & Domínio do TF \\
\hline ScSuSy 1 & TTAGnCTwAw & MA1304.1 & WRKY59 & WRKY \\
ScSuSy 1 & wATATATATw & MA1184.1 & RVE1 & Helix-Turn-Helix \\
ScSuSy 1 & rwATATATAT & MA1184.1 & RVE1 & Helix-Turn-Helix \\
ScSuSy 1 & GAATAnATAT & MA1184.1 & RVE1 & Helix-Turn-Helix \\
ScSuSy 2 & GACrAATryA & MA1374.1 & IDD7 & C2H2 \\
ScSuSy 2 & sTAskAAAAG & MA1071.1 & DOF5.3 & C2H2 \\
ScSuSy 3 & AyACTAGTrT & MA0930.1 & ABF3 & bZIP \\
ScSuSy 4 & TAGyAynTT & MA1012.1 & AGL27 & MADS box factors \\
ScSuSy 4 & TAwTTAswmA & MA0584.1 & SEP1 & MADS box factors \\
ScSuSy 4 & TATTTAsTAA & MA1181.1 & MYB113 & Helix-Turn-Helix \\
ScSuSy 5 & CTCTTkTTAT & MA1267.1 & AT5G66940 & C2H2 \\
ScSuSy 5 & CTGCTAGCAG & MA0564.1 & ABI3 & B3 domain \\
\hline
\end{tabular}


O mapeamento de cada um dos cinco TFBSs selecionados foi realizado em todas sequências de genes ScSuSy rotuladas como região Promotora. Os resultados do mapeamento demonstraram que a região Proximal do grupo ScSuSy5 apresentou apenas o TFBS identificado na própria análise de novo. Além disso este TFBS não foi compartilhado com outros grupos de genes $S c S u S y$. Este resultado indica que esta Sequência Regulatória tem papel fundamental para regulação do grupo de genes ScSuSy5. Por outro lado, o grupo ScSuSy1 apresentou o TFBS compartilhado com outros 3 grupos: ScSuSy2, ScSuSy3 e ScSusSy4. Entretanto, foi o grupo ScSuSy3 que apresentou o maior número de sequências com o TFBS ScSuSy1 mapeado.

Apesar do grupo ScSuSy3 apresentar o maior número de TFBSs compartilhados, este grupo apresentou 4 sequências sem nenhum mapeamento de TFBS na região Promotera Proximal; nem mesmo para o TFBS predito para o grupo ScSuSy3.

Curiosamente, as sequências do grupo ScSuSy1 não apresentaram mapeamento de TFBSs preditos nos outros grupos de genes ScSuSy.

Na figura 4.2 nós apresentamos a caracterização da região Promotora de todos genes ScSuSy através da classificação da região Core Promoter e do mapeamento dos TFBSs na região Promotora Proximal.

\subsubsection{Caracterização do Core Promoter dos genes homeólogos Sc- $P A L$}

De acordo com a análise filogenética anterior (Souza, GM, et 2018 - manuscrito em revisão), a família de genes $S c P A L$ está distribuída no genoma de cana-de-açúcar SP80-3280 em 5 grupos de sequências homeólogas. Cada grupo foi organizado da seguinte maneira: ScPAL1 com 20 sequências homeólogas, ScPAL2 com 2, ScPAL3 com 5, ScPAL5a com 8 e ScPAL5b com 12 sequências. Para cada grupo de genes $S c P A L$ a região Promotora foi isolada e segmentada em dois conjuntos: Core Promoter e Promotor Proximal.

As análises de classificação e rotulação da região Promotora foram realizadas individualmente. O mesmo procedimento realizado na família de genes $S c S u S y$ também foi observado para os genes ScPAL.

Os nossos resultados para a região Core Promoter dos genes $S c P A L$ demonstram que a classe TATA-less foi predominante. Na nossa análise mais de $85 \%$ das sequências apresentaram essa classificação. De acordo com a descrição no trabalho de Kumari and Ware [2013] a região Core Promoter TATA-less de plantas está mais associada com genes constitutivos. Ademais, o nosso resultado está de acordo com esta hipótese uma vez que os genes $S c P A L$ têm participação direta na via de biossíntese da parede celular [Ferreira et al., 2016].

Em geral, o tamanho médio observado para a região 5'UTR dos genes $S c P A L$ foi de 150 nt. Ao todo apenas 3 sequências não tiveram rótulo de região Promotora e estas sequências foram alocadas em três grupos diferentes: ScPAL2, ScPAL3 e ScPAL5a. A ausência da rotulação nestas 3 sequências está de acordo com a observação do tamanho médio para região 5' UTR 
dos genes $S c P A L$ uma vez que estas 3 sequências apresentaram tamanho inferior ao esperado para região 5' UTR. Portanto, nestas condições não era possível identificar o sinal de TSS através da análise in silico.

\subsubsection{Rotulação do Promotor Proximal dos genes homeólogos Sc- $P A L$}

Na avaliação da região Promotora Proximal dos genes $S c P A L$, nós executamos o mesmo processo para descoberta de TFBSs realizado nos genes $S c S u S y$. Nessa etapa de análise, nós mantivemos apenas as sequências de DNA rotuladas como região Promotora. Em cada grupo de genes $S c P A L$ foi possível identificar no mínimo 3 TFBSs diferentes, porém para o grupo ScPAL2 não foi possível identificar nenhum TFBS significativo.

O grupo ScPAL2 apresentou apenas duas sequências homeólogas no Genespace da variedade SP80-3280. Uma sequência não foi rotulado como região Promotora e outra sequência foi classificada como TATA-box. Entretanto, para o processo de predição de TFBS não foi possível identificar qualquer TFBS significativo na região Promotora Proximal dos genes ScPAL2. Este resultado foi observado independente da metodologia utilizada no processo de descoberta de novo. Ademais o grupo ScPAL2 não apresentou mapeamento para nenhum dos TFBSs preditos nos outros 4 grupos de genes ScPAL. A tabela 4.2 apresenta o resumo de todos TFBSs identificados na família de genes $S c P A L$.

Tabela 4.2: Resultado da predição de novo de TFBS na família de genes ScPAL.

\begin{tabular}{ccccc}
\hline & Sequência consenso & ID Jaspar & Nome & Classe TF \\
\hline ScPAL 1 & ArCAyATnTG & MA0930.1 & ABF3 & bZIP \\
ScPAL 1 & CAyATnTGyT & MA0930.1 & ABF3 & bZIP \\
ScPAL 3 & wGyGswnGCG & MA1000.2 & ERF105 & AP2/ERF domain \\
ScPAL 3 & GCrmCGCAmC & MA0980.1 & RAP2-10 & AP2/ERF domain \\
ScPAL 3 & CkTGyGyAnG & MA0939.1 & NAC080 & NAC/NAM \\
ScPAL 3 & GGTCsGGCkC & MA0992.1 & ERF4 & AP2/ERF domain \\
ScPAL 5a & ACTTTAGACC & MA0064.1 & PBF & C2H2 \\
ScPAL 5a & TAAGsCTTAA & MA1171.1 & MYB52 & Helix-Turn-Helix \\
ScPAL 5a & krAGTACTTA & MA1326.1 & ATHB33 & Homeo domain factors \\
ScPAL 5a & TCTAAAGTTT & MA0064.1 & PBF & C2H2 \\
ScPAL 5b & AGCTryAGCT & MA0570.1 & ABF1 & bZIP \\
ScPAL 5b & GCCGGAACGG & MA1009.1 & ARF3 & B3 domain \\
ScPAL 5b & ACrGCTrCAG & MA0575.1 & MYB77 & Tryptophan cluster factors \\
\hline
\end{tabular}

Seguindo o mesmo procedimento adotado para os genes $S c S u S y$, nós realizamos a seleção de apenas um único TFBS para cada grupo de genes $S c P A L$. Estes TFBSs foram mapeados em todas sequências homeólogas ScPAL. Sendo assim para o grupo ScPAL1 foi mantido o TFBS (ArCAyATnTG) relacionado com elemento ABF3 [Kang et al., 2002, Khan et al., 2017]. Em geral este elemento ABF3 está envolvido com a regulação de genes responsivos a 
estresse abiótico além de potencializar a transdução de sinal via glicose. No grupo ScPAL3 nós selecionamos o TFBS GGTCsGGCkC e este foi associado com o elemento AP2/ERF [Fujimoto et al., 2000, Khan et al., 2017]. No grupo ScPAL5a o TFBS selecionado apresentou a sequência consenso conservada TCTAAAGTTT e este padrão foi atribuído ao elemento PBF [Khan et al., 2017, Yanagisawa and Schmidt, 1999]. Apesar da diferença dos TFBSs entre os grupos ScPAL3 e ScPAL5a, estes dois TFBS podem atuar no mesmo grupo de genes ou via de regulação. Em geral o efeito destes elementos pode ocorrer durante a via de transdução de sinal para estresse abiótico ou através da regulação da expressão de genes envolvidos diretamente com o estresse abiótico [Fujimoto et al., 2000, Khan et al., 2017, Yanagisawa and Schmidt, 1999]. Para o grupo ScPAL5b, nós selecionamos a sequência consenso conservada GCCGGAACGG [Hagen and Guilfoyle, 2002, Khan et al., 2017]. Geralmente este TFBS tem papel direto no processo de regulação genes relacionados com a via de atuação dos fitohormônios ABA e auxina e este TFBS foi associado com o elemento ARF3 [Khan et al., 2017].

Com exceção do grupo ScPAL5b que apresentou compartilhamento de TFBSs preditos no grupo ScPAL3 em mais de $80 \%$ das sequências, todos os outros grupos de genes ScPAL tiveram apenas TFBSs mapeados do seu próprio grupo de predição. Na figura 4.3 nós apresentamos a caracterização da região Promotora de todos genes $S c P A L$ através da classificação da região Core Promoter e do mapeamento dos TFBSs na região Promotora Proximal.

\subsection{RNA-Seq de cana de açúcar}

A análise do transcriptoma foi realizada em 5 conjuntos de dados transcriptoma diferentes. Sendo que apenas um conjunto foi obtido exclusivamente de cana-de-açúcar SP80-3280 e outros conjuntos de diferentes plantas de cana-e-açúcar (variedades). A identificação de genes expressos, co-expressos ou diferencialmente expressos em cana-de-açúcar foi realizada no Genescpace de SP80-3280.

\subsubsection{Identificação dos genes expressos no Transcriptoma de cana- de-açúcar}

O Genescpace de SP80-3280 apresenta 373,869 genes putativos (Souza, GM, et 2018 - manuscrito em revisão) e deste conjunto 59,594 genes expressos; dados do transcriptoma de cana-de-açúcar SP80-3280 submetida à seca (dados não publicados); 59,763 genes em Cardoso-Silva et al. [2014], 87,364 genes expressos em Li et al. [2016]; 12.117 genes expressos em Nishiyama et al. [2014] e 34,307 gene expressos obtidos no conjunto de Vicentini et al. [2015]. Na figura 4.4 apresentamos os dados de expressão para cada transcriptoma analisado. Nós apresentamos os genes diferencialmente expressos usando gráficos Volcano plot contrastando o $\log _{1} 0$ do $p$-value com o $\log _{2}$ do fold change. Apesar do trans- 
criptoma de Nishiyama et al. [2014] apresentar o menor número de genes expressos, esse valor está próximo do número de genes estimados pelos autores de 17,563 genes full-length [Nishiyama et al., 2014]. Para os transcriptomas de cana-de-açúcar SP80-3280 e Li et al. [2016] foi possível identificar genes diferencialmente expressos nos valores próximos ao número de total de genes estimado para cana-de-açúcar ( 35,000 genes) (Souza, GM, et 2018 - manuscrito em revisão). Sendo que para cana-de-açúcar SP80-3280 foi possível identificar mais de 44,000 e para Li et al. [2016] 38,000 genes diferencialmente expressos.

Em seguida foi realizado a identificação da expressão gênica de cada sequência homeóloga dos genes $S c d r 1, S c S u S y$ e $S c P A L$ nos cinco transcriptomas. Nas figuras 4.4, 4.5, 4.7, 4.9, 4.11, 4.13, 4.15, 4.17, 4.19, 4.21, 4.23 e 4.25 apresentamos o heatmap de expressão para cada sequência homeóloga dos genes analisados no transcriptoma de cana-de-açúcar SP80-3280 sob estresse hídrico.

\subsubsection{Identificação de genes co-expressos no Transcriptoma de cana- de-açúcar}

Em seguida, 50 genes co-expressos (gene alvo +49 genes com expressão similar ao gene alvo) em cada transcriptoma foram recuperados para análise da região Promotora. Para seleção destes genes, nós utilizamos o dado de expressão de apenas uma única sequência homeóloga dos genes $S c d r 1, S c S u S y$ e $S c P A L$. A seleção foi obtida a partir da expressão diferencial de cada sequência homeóloga observada em três conjuntos de transcriptoma diferentes. As figuras 4.6, 4.8,4.10,4.12,4.14,4.16,4.18,4.20,4.22,4.24 e 4.26 apresentam 50 genes co-expressos no transcriptoma de cana-de-açúcar SP80-3280 sob estresse hídrico.

\subsubsection{Análise da região Promotora de genes co-expressos}

O mapeamento dos TFBS de ScSuSy1 em média 29 genes nos grupos de genes coexpressos de ScSuSy1,ScSuSy3, Scdr1, ScPal1, ScPal2, Pal5a, e ScPal5b. Curiosamente estes grupos apresentam TFBSs relacionados com respostas à estresse abiótico, porém todos apresentaram expressão maior em amostras de Raiz Irrigada; com exceção do grupo ScSuSy3 que apresentou maior expressão em amostras de Raiz Seca. Curiosamente, o TFBS de ScSuSy1 foi mapeado não foi identificado na família de genes ScPal2, entretanto, o grupo de genes co-expressos com gene ScPal2apresentou o mapeamento deste TFBSs. Esse resultado pode indicar que regulação do gene $S c P a l 2$ pode ocorrer indiretamente por outros fatores que não estão relacionados com os TFBSs preditos na nossa avaliação. Por outro lado, o gene $S c d r 1$ apresentou o TFBS de ScSuSy1 mapeado na região Promotora, porém, a expressão do gene $S c d r 1$ foi mais aparente nas amostras de Raiz Irrigada do que em Raiz Seca. Esse resultado é diferente do esperado para este gene, uma vez que este gene foi associado à plantas mais tolerantes à seca [Begcy et al., 2012]. Ademais, na análise da região Promotora do grupo de genes co-expressos $S c d r 1$ também apresentou TFBSs $S c P A L 1$, e com isso é possível esperar 
que este grupo de genes tenham alguma associação com diferentes mecanismos de ativação da regulação como: o relógio circadiano e sinalização de auxina (ScSuSy1) [Khan et al., 2017]; responsivos à estresse abiótico e potencializador da transdução de sinal via glicose (ScPAL1) [Khan et al., 2017] e responsivos à estresse abiótico (Scdr1)[Khan et al., 2017].

Nós identificamos os TFBS de $S c S u S y 4$ em 20 genes nos grupos de genes co-expressos de ScSuSy3, ScSuSy4 e ScPAL5b. Além disso, os TFBS de ScSuSy3 também foram observados nos grupos de genes co-expressos $S c S u S y 4$ e $S c P A L 5 b$ e para os TFBSs do grupo de $S c P A L 5 b$ apenas o grupo de genes co-expressos de $S c S u S y 3$ apresentaram o mapeamento dos TFBSs preditos em ScPAL5b. Nestes três grupos, todos os genes apresentaram maior expressão nas amostras de Raiz Seca. Este resultado é um indicativo que os estes três grupos de genes coexpressos estão sujeitos a processo de regulação comum uma vez que entre eles houve TFBSs compartilhados na região Promotora. Além disso, a expressão diferencial destes genes ocorreu na mesma condição (Raiz Seca).

Apesar do grupo de genes co-expressos ScSuSy4 apresentar região Promotora TATAless, os genes co-expressos $S c S u S y 4$ foram expressos na mesma condição dos genes $S c S u S y 3$ e $S c P A L 5 b$. Este fator pode indicar que a regulação destes grupos pode estar ocorrendo principalmente em função dos TFBSs identificados na região Promotora Proximal e em menor efeito pela região Core Promoter.

O TFBS predito em ScPAL3 foi compartilhado principalmente com o grupo de genes coexpressos $S c P A L 5 b$. Este resultado foi similar ao observado quando nós analisamos apenas as famílias gênicas $S c P A L 3$ e $S c P A L 5 b$. Nestas famílias a região Promotora compartilha os mesmos TFBSs mapeados nos grupos de genes co-expressos ScPAL3 e ScPAL5b.

Os TFBSs ScSuSy2, ScSuSy5, ScPAL5a e ScPAL5b apresentaram mapeamento menor que $5 \%$ e os TFBSs $S c d r 1$ e $S c S u S y 3$ apresentaram TFBS mapeados em $10 \%$ em todas as sequências analisadas de genes co-expressos.

\subsection{TSSFinder preditor do sinal de TSS em eucariotos}

A ferramenta TSSFinder foi desenvolvida em parceria com o aluno de doutorado em Ciência da Computação Ígor Bonadio (Programa de Pós-Graduação em Ciência da Computação do IME-USP), além da co-orientação do Professor Alan Mitchell Durham. Os resultados apresentados nesta seção estão acompanhado do anexo (Oliveira, et al, 2018 - manuscrito em preparação).

\subsubsection{Validação do modelo}

O processo de validação da ferramenta TSSFinder foi realizada em cinco subgrupos de dados genômicos para os organismos A.thaliana, D. melanogaster, G. gallus, H. sapiens, S. pombe, S. cerevisiae e O. sativa. Com este conjunto de organismos a ferramenta TSSFinder foi validada considerando 4 cenários diferentes: 
- diferentes organismos: animais, plantas e fungos;

- organismo modelo (como exemplo D. melanogaster e não modelo (G. gallus);

- plantas Dicotiledôneas (A.thaliana) e Monocotiledôneas (O. sativa);

- dados validados por experimentos de TSS-Seq (A.thaliana) e fl-cDNA (O. sativa).

A tabela 4.3 apresenta o resultado de predição do sinal de TSS considerando diferentes janelas de nucleotídeos (distância em nt do TSS predito em relação ao TSS curado). Nessa tabela apresentamos a média e o desvio padrão para cinco subgrupos de dados. A identificação do TSS foi considerada correta se o sinal predito pela ferramenta foi próximo ao sinal de TSS validado. Para determinação de proximidade com o sinal de TSS validado nós consideramos 5 janelas de nucleotídeos: 50 nt, 100 nt, 150 nt, 200 nt e 250 nt.

Tabela 4.3: Resultado de predição do TSSFinder para o sinal de TSS em diferentes organismos ${ }^{1}$

\begin{tabular}{lccccc}
\hline Organismos & $50 \mathrm{nt}$ & $100 \mathrm{nt}$ & $150 \mathrm{nt}$ & $200 \mathrm{nt}$ & $250 \mathrm{nt}$ \\
& & & & & \\
\hline A.thaliana & 67,7 & 83.4 & 86.3 & 87.8 & 94.4 \\
& $( \pm 0.6)$ & $( \pm 0.4)$ & $( \pm 1.2)$ & $( \pm 1.6)$ & $( \pm 0.7)$ \\
D. melanogaster & 48.4 & 60.3 & 67.7 & 72.0 & 76.1 \\
& $( \pm 1.7)$ & $( \pm 1.4)$ & $( \pm 1.0)$ & $( \pm 0.9)$ & $( \pm 0.7)$ \\
G. gallus & 52.9 & 74.2 & 84.7 & 90.8 & 94.5 \\
& $( \pm 0.8)$ & $( \pm 0.7)$ & $( \pm 0.5)$ & $( \pm 0.5)$ & $( \pm 0.6)$ \\
H. sapiens & 32.2 & 47.7 & 57.0 & 64.6 & 70.0 \\
& $( \pm 2.9)$ & $( \pm 1.6)$ & $( \pm 2.3)$ & $( \pm 1.5)$ & $( \pm 1.3)$ \\
S. cerevisiae & 75.7 & 94.9 & 99.9 & 99.9 & 99.9 \\
& $( \pm 0.6)$ & $( \pm 0.4)$ & $( \pm 0.0)$ & $( \pm 0.0)$ & $( \pm 0.0)$ \\
S. pombe & 63.6 & 73.5 & 80.2 & 85.7 & 88.4 \\
& $( \pm 1.0)$ & $( \pm 0.8)$ & $( \pm 1.5)$ & $( \pm 1.0)$ & $( \pm 0.7)$ \\
O. sativa & 47.1 & 68.4 & 79.1 & 87.2 & 93.3 \\
& $( \pm 0.7)$ & $( \pm 0.8)$ & $( \pm 0.8)$ & $( \pm 0.8)$ & $( \pm 0.7)$ \\
\hline
\end{tabular}

Considerando o tamanho de 100 nt a ferramenta TSSFinder conseguiu identificar mais de 60\% do sinal de TSS em todos os organismos; com exceção de H.sapiens (47.7\%). Além disso o desempenho da ferramenta foi superior a $80 \%$ em $A$. thaliana e $95 \% \mathrm{em}$ S. cerevisiae. Este resultado é indicativo de que o modelo desenvolvido na ferramenta é capaz de rotular o sinal de TSS mesmo quando consideramos organismos completamente diferentes. Ademais o desvio padrão observado no processo de validação da ferramenta foi pequeno e essa informação é mais um indicativo da robustez do modelo para executar a identificação do sinal de TSS. Na figura 4.27 apresentamos o histograma de distância entre o sinal de TSS rotulado pelo TSSFinder e o sinal TSS validado apenas em um organismo de cada grupo. Cada barra representa o intervalo de $10 \mathrm{nt}$.

\footnotetext{
${ }^{1}$ Valores em porcentagem e entre parênteses o desvio padrão.
} 
No início do desenvolvimento da ferramenta TSSFinder nós observamos que o processo de predição era realizado em minutos. Entretanto para o processo de treinamento, a tarefa era executada em dias. Então nós observamos o tempo de execução da ferramenta usando 2 conjuntos: i) Treinamento: 12 subconjuntos de sequências com o tamanho variando de 285 até 9108 sequências e ii) Predição: 8 subconjuntos com o número de sequências variando de 926 até 15700 . O tempo de execução de cada subconjunto é apresentado na tabela 4.4 do conjunto de treinamento e na tabela 4.5 para o conjunto de predição.

Tabela 4.4: Tempo médio de execução da ferramenta TSSFinder durante o treinamento

\begin{tabular}{|c|c|c|c|c|c|}
\hline & Duração & 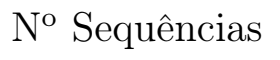 & & Duração & No Sequências \\
\hline A. thaliana & $255 \mathrm{~h} 22 \mathrm{~min} 21 \mathrm{~s}$ & 3925 & O. sativa & $512 \mathrm{~h} 17 \mathrm{~min} 27 \mathrm{~s}$ & 9108 \\
\hline D. melanogaster & $71 \mathrm{~h} 44 \mathrm{~min} 38 \mathrm{~s}$ & 2952 & O. sativa & $316 \mathrm{~h} 47 \mathrm{~min} 25 \mathrm{~s}$ & 4554 \\
\hline H. sapiens & $92 \mathrm{~h} 06 \mathrm{~min} 26 \mathrm{~s}$ & 4248 & O. sativa & $149 \mathrm{~h} 01 \mathrm{~min} 20 \mathrm{~s}$ & 2277 \\
\hline G. gallus & $28 \mathrm{~h} 32 \mathrm{~min} 32 \mathrm{~s}$ & 1119 & O. sativa & $70 \mathrm{~h} 06 \mathrm{~min} 09 \mathrm{~s}$ & 1139 \\
\hline S. cerevisiae & $20 \mathrm{~h} 13 \mathrm{~min} 18 \mathrm{~s}$ & 937 & O. sativa & $39 \mathrm{~h} 15 \mathrm{~min} 34 \mathrm{~s}$ & 570 \\
\hline S. pombe & $43 \mathrm{~h} 53 \mathrm{~min} 12 \mathrm{~s}$ & 926 & O. sativa & $16 \mathrm{~h} 06 \mathrm{~min} 47 \mathrm{~s}$ & 285 \\
\hline
\end{tabular}

Tabela 4.5: Tempo médio de execução da ferramenta TSSFinder durante a predição

\begin{tabular}{lll} 
Organismos & Duração & $N^{o}$ Sequências \\
\hline A. thaliana & 01h 23min 02s & 15700 \\
O. sativa & $30 \min 12 \mathrm{~s}$ & 9108 \\
H. sapiens & $23 \min 59 \mathrm{~s}$ & 4248 \\
A. thaliana & $16 \operatorname{min~} 37 \mathrm{~s}$ & 3925 \\
D. melanogaster & $8 \min 58 \mathrm{~s}$ & 2952 \\
G. gallus & $9 \min 07 \mathrm{~s}$ & 1119 \\
S. cerevisiae & 7 min $23 \mathrm{~s}$ & 937 \\
S. pombe & 7 min $23 \mathrm{~s}$ & 926 \\
\hline
\end{tabular}

Como era esperado, o tempo de execução da ferramenta TSSFinder aumenta à medida que conjunto de sequências também cresce. Esse comportamento foi similar tanto na etapa de treinamento do modelo quanto durante o processo de predição. Entretanto, o tempo de execução da ferramenta TSSFinder durante o processo de predição foi menor, mesmo quando a tarefa foi realizada no maior conjunto de sequências analisadas (15700 sequências - tempo de execução 1 hora e 30 minutos). Esse resultado indica que o modelo de predição do TSSFinder é capaz de executar a tarefa de predição do sinal de TSS rapidamente em diferentes cenários. 


\subsubsection{TSSFinder $v s$ outras ferramentas}

O desempenho da ferramenta TSSFinder foi comparado com outros dois modelos de predição do sinal de TSS: TIPR [Morton et al., 2015] e TSSPlant Shahmuradov et al. [2017]. Estes dois modelos foram publicados recentemente e de acordo com os seus desenvolvedores a predição do sinal de TSS ficou acima de $80 \%$. Além disso na ferramenta TIPR a predição do TSS apresentou resolução de 10 nt, enquanto na ferramenta TSSPlant essa predição é resolvida utilizando uma janela de $251 \mathrm{nt}$.

A avaliação dos três modelos foi realizada no mesmo grupo de sequências de DNA, este conjunto é formado por sequências da região Promotora de A. thaliana com o TSS curado. O resultado de desempenho para as três ferramentas é apresentado na tabela 4.6. Nessa etapa de análise não foi possível realizar um novo treinamento para as duas ferramentas avaliadas uma vez que estas não apresentavam a possibilidade de re-treinamento do modelo de predição com outro conjunto de dados.

Tabela 4.6: Desempenho do modelo TSSFinder contra outras ferramentas

\begin{tabular}{lccccc} 
Ferramentas & $50 \mathrm{nt}$ & $100 \mathrm{nt}$ & $150 \mathrm{nt}$ & $200 \mathrm{nt}$ & $250 \mathrm{nt}$ \\
\hline TSSFinder & 69.4 & 84.3 & 90.2 & 92.7 & 93.8 \\
TIPR & 42.7 & 52.3 & 56.1 & 58.07 & 59.3 \\
TSSPlant & 26.1 & 36.4 & 43.8 & 50.6 & 56.7 \\
\hline
\end{tabular}

De acordo com a nossa avaliação, a ferramenta TSSFinder foi superior aos modelos TIPR e TSSPlant em todas janelas (distância em nt do TSS predito em relação ao TSS curado) de nucleotídeos avaliadas. Além disso, a identificação do sinal de TSS realizada pelo modelo TSSFinder apresentou maior ganho à medida que a janela de nucleotídeos era expandida. Este comportamento não foi observado para os outros dois modelos. Curiosamente os modelos TIPR e TSSPlant apresentaram resultados de predição inferior ao que foi descrito pelos desenvolvedores mesmo quando consideramos especificamente as janelas de 10 nt para o TIPR (28\%) e de 250 nt para TSSPlant (56\%) como podemos observar na figura 4.28. Nesta figura nós apresentamos os resultados de predição para cada ferramenta com resolução de $10 \mathrm{nt}$ (valor referente a cada barra). Estes resultados indicam que a ferramenta TSSFinder apresenta maior habilidade para identificação do sinal de TSS mesmo em janelas de nucleotídeos curtas como apresentada na figura 4.28.

Durante a validação da ferramenta TSSFinder nós observamos que o processo de predição realizado pela nossa ferramenta era muito rápido. Então para verificar a robustez dessa característica nós comparamos tempo de execução da nossa ferramenta TSSFinder contra as ferramentas TIPR e TSSPlant. Nessa análise nós utilizamos o mesmo conjunto de sequências 
utilizado na análise de predição comparativa entre as três ferramentas. Além disso, todos os processos foram executados no servidor da rede eScience - IME Intel(R) Xeon(R) CPU E5-2690 0 @ 2.90GHz, 32 processing cores and 256Gb RAM (FAPESP grant 2011 / 50761-2, CNPq, CAPES, NAP eScience - PRP - USP). Os resultados dessa avaliação são apresentados na tabela 4.7.

Tabela 4.7: Tempo de execução do processo de predição nas ferramentas TSSFinder, TSSPlant e TIPR

\begin{tabular}{lcccc}
\hline & TSSFinder & TSSPlant & TIPR & TIPR \\
\hline CPU & 1 & 1 & 5 & 1 \\
\hline \multirow{2}{*}{ Execução } & 0 h12min26s & $6 \mathrm{~h} 39 \mathrm{~min} 48 \mathrm{~s}$ & $274 \mathrm{~h} 8 \mathrm{~min} 30 \mathrm{~s}$ & 1370h45min12s
\end{tabular}

Os resultados desse ensaio demonstraram que a velocidade de predição do nosso modelo é muito superior aos praticados pelas outras duas ferramentas. O tempo de execução do TSSFinder foi $1000 \mathrm{x}$ menor do que observado utilizando-se o TIPR e $30 \mathrm{x}$ menor que o tempo de execução do TSSPlant. Ademais, entre os três modelos, o TIPR apresentou o maior tempo de execução com 1370 horas, 45 minutos e 12 segundos e mesmo após a divisão do conjunto de dados em 5 subgrupos, o tempo de execução do TIPR foi superior a 100x ao praticado pelo modelo TSSFinder

Neste ensaio não avaliamos o tempo de treinamento entre os modelos uma vez que o TIPR e TSSPlant não foram configurados para serem treinados novamente pelo usuário final.

\subsubsection{Determinação do conjunto de treinamento}

Apesar do modelo TSSFinder apresentar excelente características, o processo de treinamento realizado pelo TSSFinder é muito lento quando comparado com o tempo que a ferramenta leva para executar a tarefa de predição. Para contornar essa situação é necessário determinar qual tamanho de sequências é suficiente para treinar o modelo sem prejudicar as características competitivas do mesmo.

Essa tarefa foi realizada através do treinamento do modelo TSSFinder com conjuntos de dados de diferentes tamanhos. Todos os dados são oriundos de sequências de DNA da região Promotora de O. sativa. A tabela 4.8 apresenta os resultados de predição para o modelo TSSFinder treinado nos conjuntos de dados com 4554, 2277, 1138, 569 e 285 sequências.

Os resultados dessa avaliação demonstraram que um grupo de 285 sequências foi suficiente para treinar o modelo TSSFinder sem prejudicar a identificação do sinal de TSS assim como 
Tabela 4.8: Resultado de predição do TSSFinder para diferentes conjuntos de treinamento

\begin{tabular}{lccccc}
\hline & & & & & \\
No Sequências & $50 \mathrm{nt}$ & $100 \mathrm{nt}$ & $150 \mathrm{nt}$ & $200 \mathrm{nt}$ & $250 \mathrm{nt}$ \\
& & & & & \\
\hline & & & & & \\
9108 & 47.1 & 68.4 & 79.1 & 87.2 & 93.3 \\
4554 & 46.8 & 67.2 & 78.4 & 86.8 & 93.1 \\
2277 & 45.6 & 67.1 & 78.8 & 87.4 & 94.0 \\
1138 & 44.0 & 64.7 & 76.7 & 85.3 & 92.1 \\
289 & 42.4 & 64.5 & 76.7 & 86.0 & 93.5 \\
\hline
\end{tabular}

o tempo para execução da predição do modelo (dados não apresentados). Na tabela 4.8 podemos perceber que identificação do sinal de TSS teve pouca variação entre os conjuntos de treinamento avaliados e esse comportamento foi mantido para todas janelas de nucleotídeos consideradas. Ademais, de acordo com a tabela 4.4 o processo de treinamento realizado no conjunto de dados com 285 sequências foi de 16 horas e 06 minutos e esse valor corresponde a uma redução no tempo de treinamento de aproximadamente de 496 horas em comparação com o conjunto de 9108 sequências. Além disso, podemos considerar essa redução no tempo de execução um ganho real pois a diferença de predição entre o maior conjunto de sequências e o menor foi de apenas $6 \%$. Com isso fica evidente que essa diferença nos valores de predição entre estes conjuntos não justifica o tempo gasto de 512 horas e 17 minutos para treinar o modelo TSSFinder com 9108 sequências. 

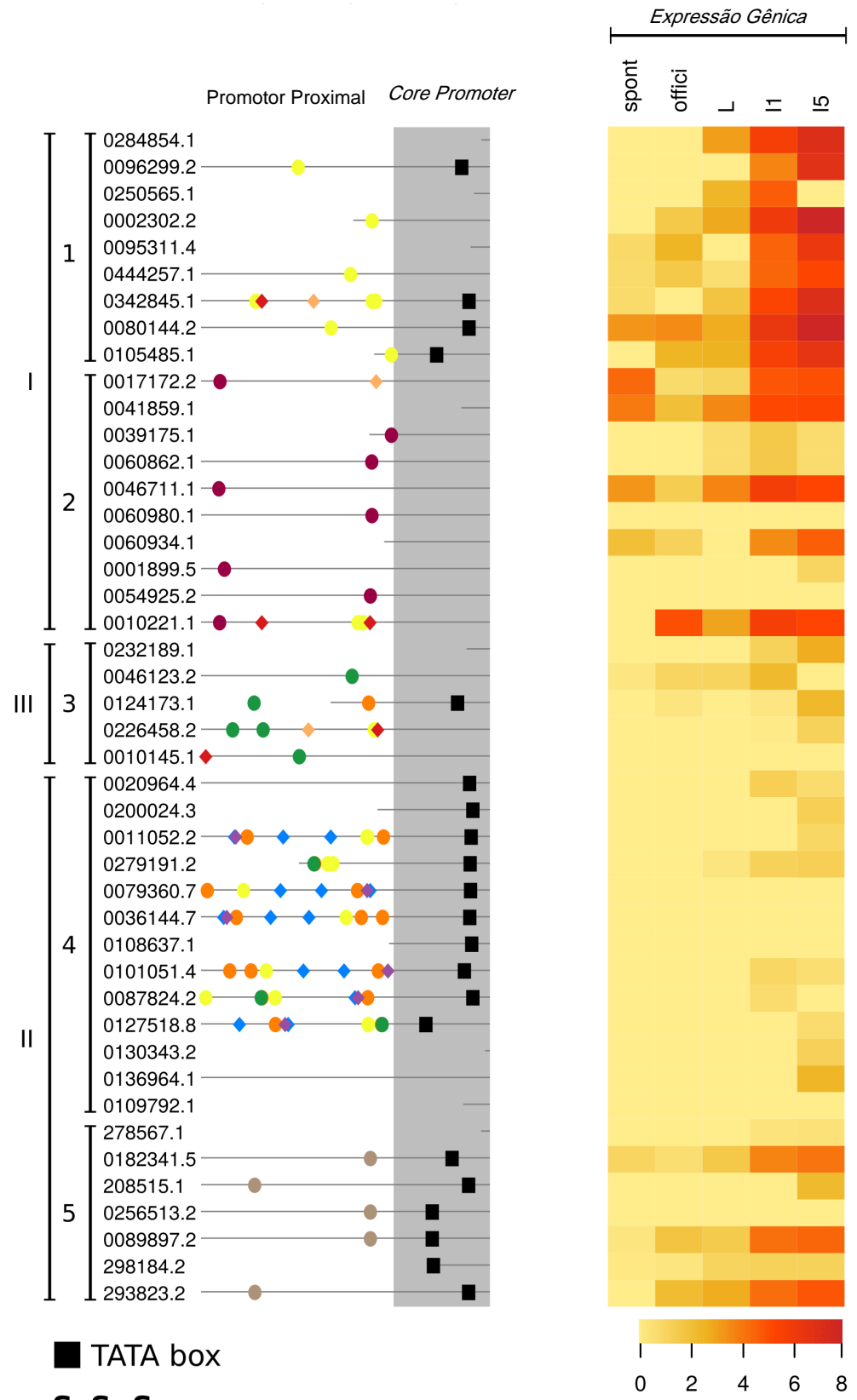

\section{ScSuSy}

\begin{tabular}{ll}
\hline TFBS SuSy & TFBS PAL \\
predicăo de novo & mapeamento em SuSy \\
CTGCTAGCAG & GCCGGAACGG \\
TAGyAynTTT & TCTAAAGTTT \\
AyACTAGTrT & GGTCsGGCkC \\
GACrAATryA & $\diamond$ ArCAyATnTG \\
wATATATATw &
\end{tabular}

Figura 4.2: Caracterização da região Promotora dos genes ScSuSy. Representação da arquitetura putativa da região Promotora dos genes ScSuSy. Linha horizontal preta dentro do retângulo cinza: subsequências de DNA Core Promoter. Linha horizontal preta: subsequências de DNA Promotora Proximal. Gráfico Heatmap para os genes ScSuSy em plantas de cana-de-açúcar Saccharum spontaneum, Saccharum officinarum e SP80-3280.Créditos: Augusto Diniz 


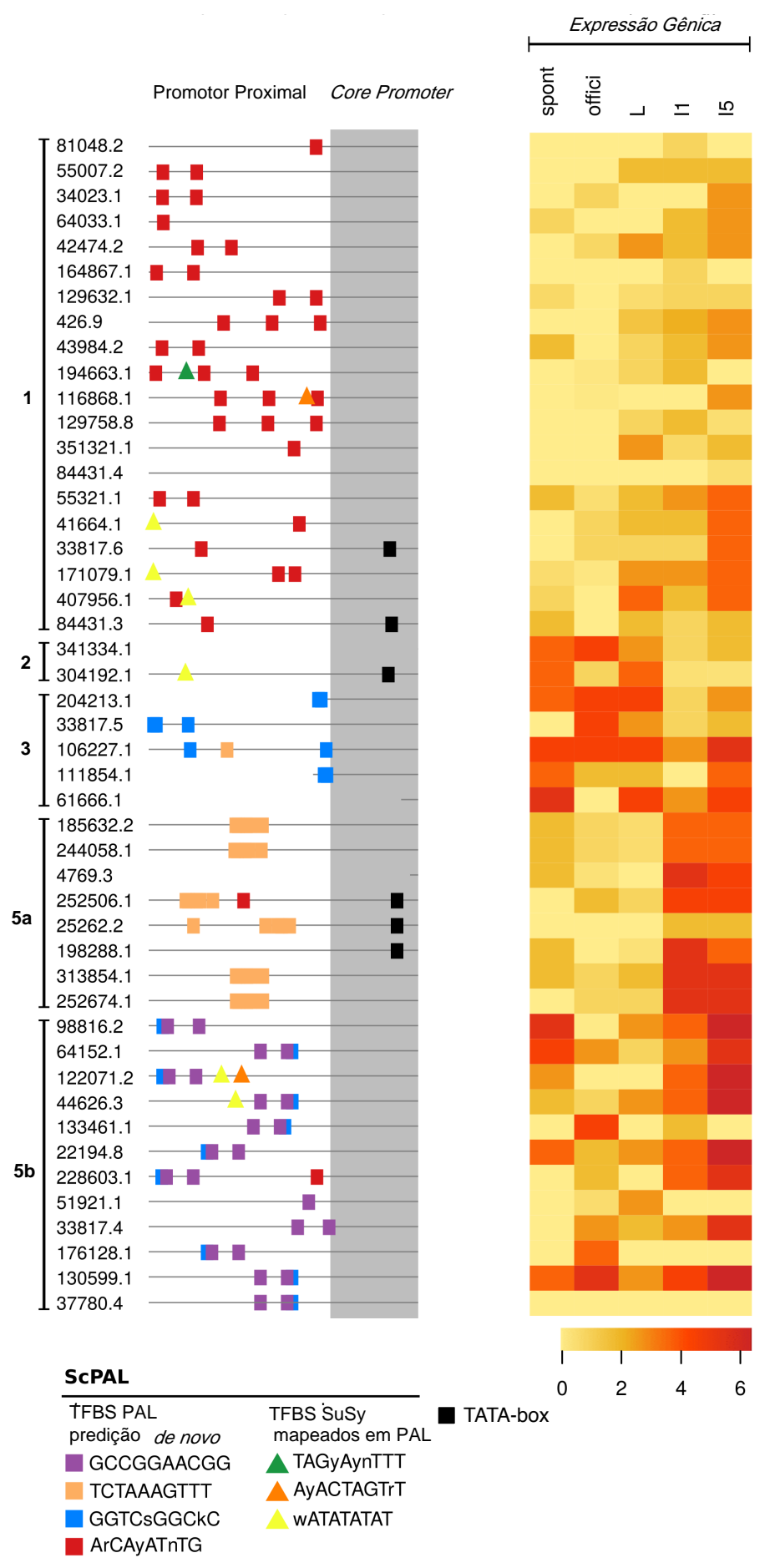

Figura 4.3: Caracterização da região Promotora dos genes ScPAL. Representação da arquitetura putativa da região Promotora dos genes $S c P A L$. Linha horizontal preta dentro do retângulo cinza: subsequências de DNA Core Promoter. Linha horizontal preta: subsequências de DNA Promotora Proximal. Gráfico Heatmap para os genes $S c P A L$ em plantas de cana-de-açúcar Saccharum spontaneum, Saccharum officinarum e SP80-3280. Créditos: Augusto Diniz. 


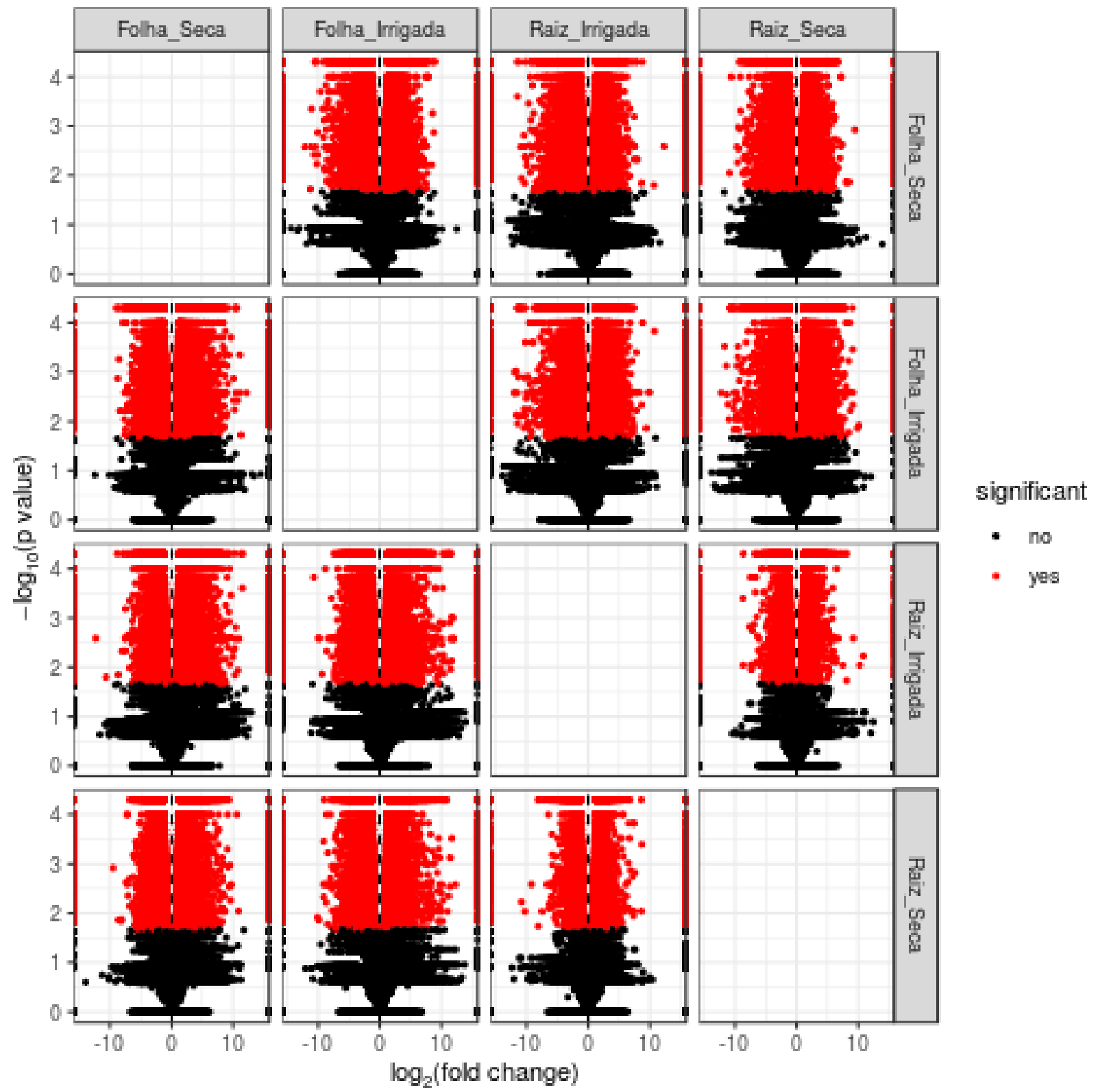

Figura 4.4: Dados de expressão do transcriptomas de cana-de-açúcar SP80-3280 sob estresse hidrico

O eixo horizontal apresenta os valores de $\log _{2}$ do fold change e o eixo vertical os valores de $\log _{1} 0$ do $p$-value. As linhas e colunas representam os tecidos e condições avaliadas no ensaio. 


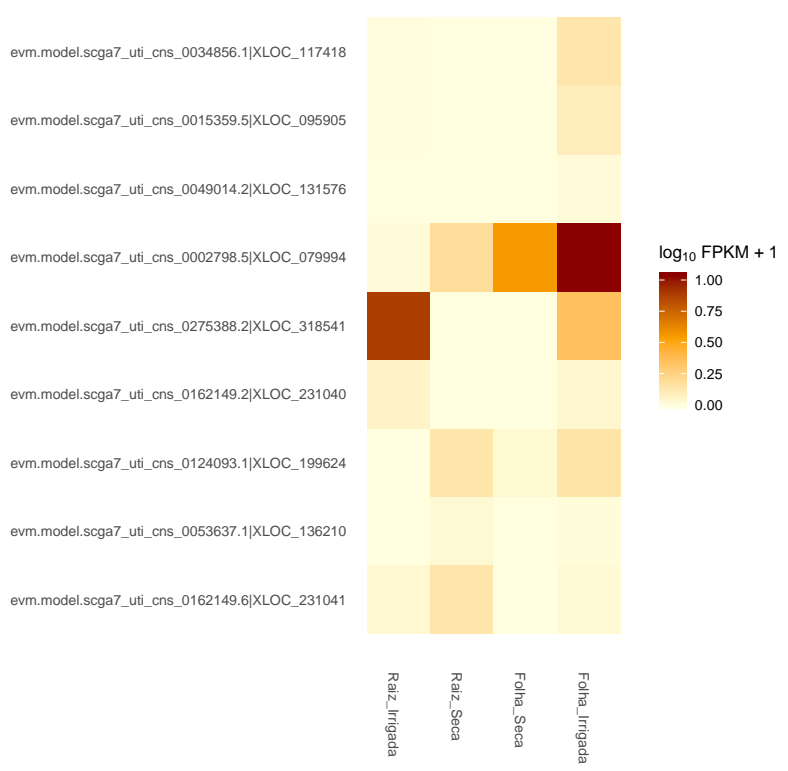

Figura 4.5: Expressão gênica de sequências homeólogas do gene Scdr1 no transcriptoma de SP803280.

Expressão gênica de sequências homeólogas do gene $S c d r 1$ no transcriptoma de cana-deaçúcar SP80-3280 sob estresse hídrico. Linhas: Identificador dos genes no Genescpace de SP80-3280. Colunas: Amostras avaliadas no ensaio de Raiz e Folha.

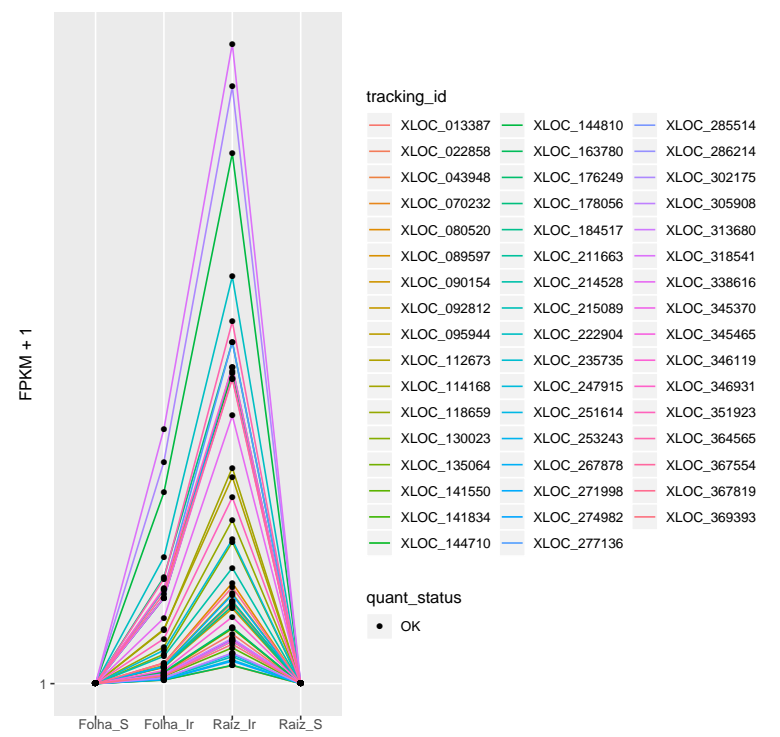

Figura 4.6: Genes co-expressos com gene Scdr1 no transcriptoma de SP80-3280. Dados do transcriptoma de cana-de-acúcar de SP80-3280 sob estresse hídrico. Apresentação de 49 genes com expressão similar ao gene Scdr1 (275388.2 | XLOC_318541) Linhas: Identificador dos genes no Genescpace de SP803280. Colunas: Amostras avaliadas no ensaio de Raiz e Folha. 


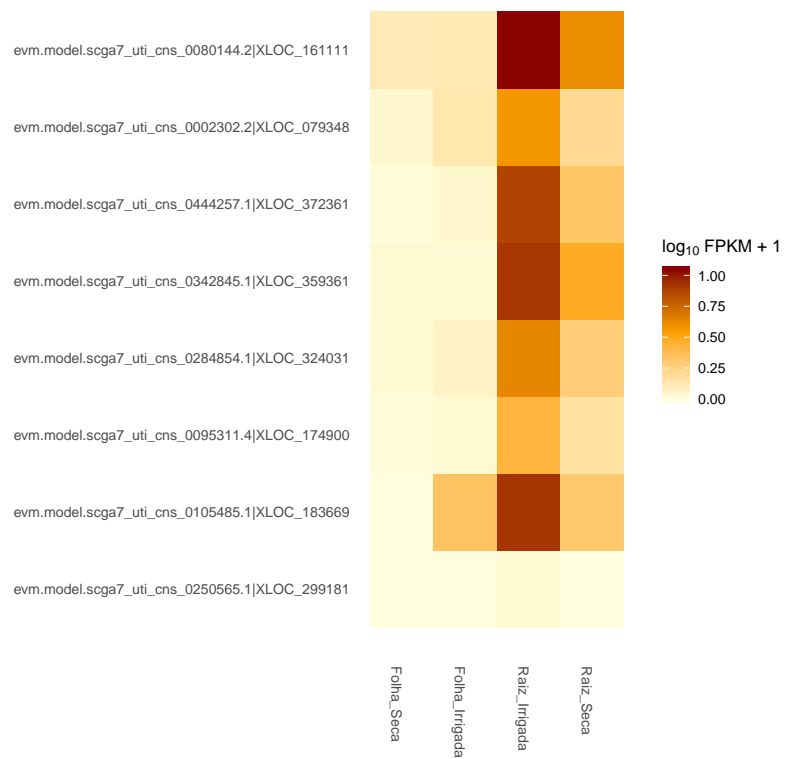

Figura 4.7: Expressão da família gênica ScSuSy1 no transcriptoma de SP80-3280. Expressão gênica de sequências homeólogas da família de genes $S c S u S y 1$ no transcriptoma de cana-de-açúcar SP80-3280 sob estresse hídrico. Linhas: Identificador dos genes no Genescpace de SP80-3280. Colunas: Amostras avaliadas no ensaio de Raiz e Folha.

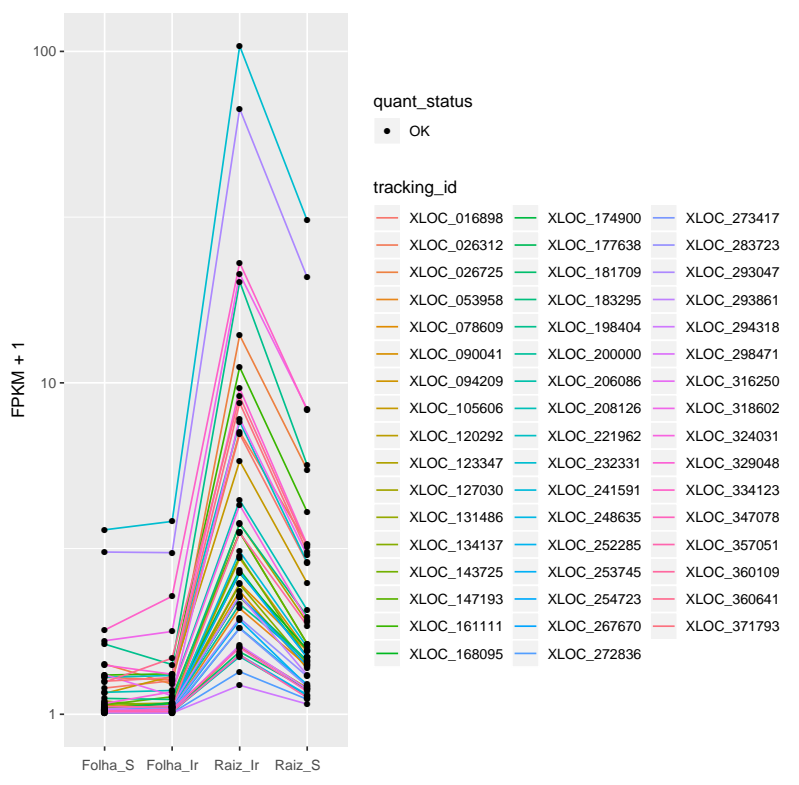

Figura 4.8: Genes co-expressos com gene ScSuSy1 no transcriptoma de SP80-3280. Dados do transcriptoma de cana-de-acúcar de SP80-3280 sob estresse hídrico. Apresentação de 49 genes com expressão similar ao gene ScSuSy1 (80144.2 | XLOC_161111) Linhas: Identificador dos genes no Genescpace de SP80-3280. Colunas: Amostras avaliadas no ensaio de Raiz e Folha. 


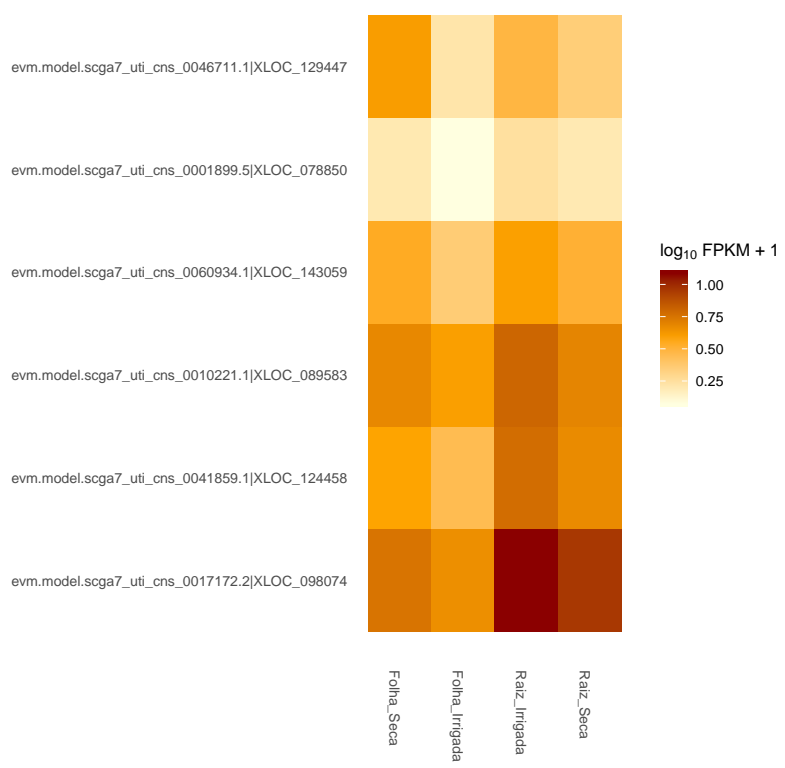

Figura 4.9: Expressão da família gênica ScSuSy2 no transcriptoma de SP80-3280. Expressão gênica de sequências homeólogas da família de genes ScSuSy2 no transcriptoma de cana-de-açúcar SP80-3280 sob estresse hídrico. Linhas: Identificador dos genes no Genescpace de SP80-3280. Colunas: Amostras avaliadas no ensaio de Raiz e Folha.

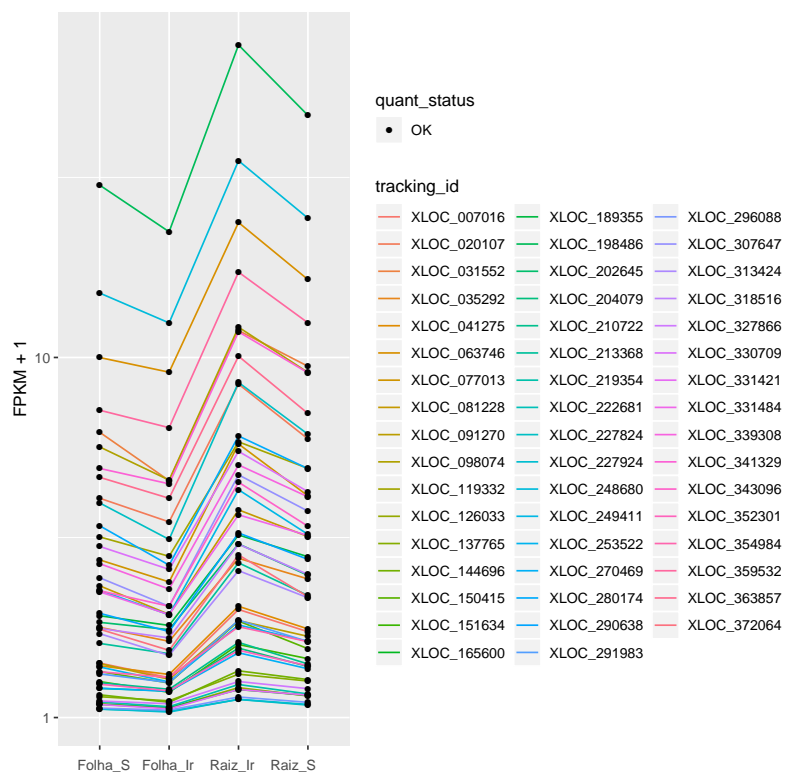

Figura 4.10: Genes co-expressos com gene ScSuSy2 no transcriptoma de SP80-3280. Dados do transcriptoma de cana-de-açúcar de SP80-3280 sob estresse hídrico. Apresentação de 49 genes com expressão similar ao gene ScSuSy2 (17172.2 | XLOC_098074) Linhas: Identificador dos genes no Genescpace de SP80-3280. Colunas: Amostras avaliadas no ensaio de Raiz e Folha. 


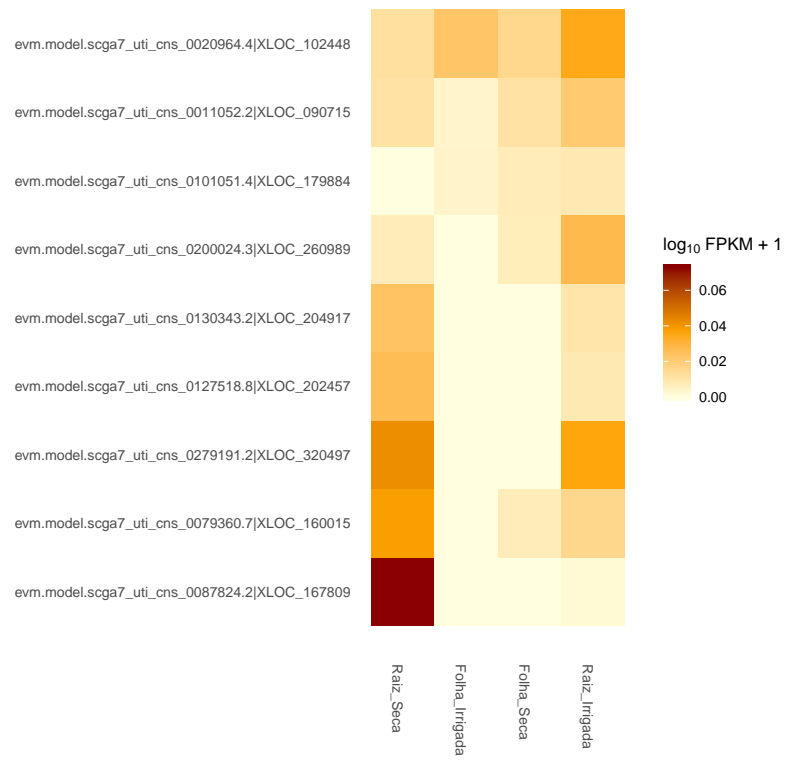

Figura 4.11: Expressão da família gênica ScSuSy3 no transcriptoma de SP80-3280 Expressão gênica de sequências homeólogas da família de genes $S c S u S y 3$ no transcriptoma de cana-de-açúcar SP80-3280 sob estresse hídrico. Linhas: Identificador dos genes no Genescpace de SP80-3280. Colunas: Amostras avaliadas no ensaio de Raiz e Folha.

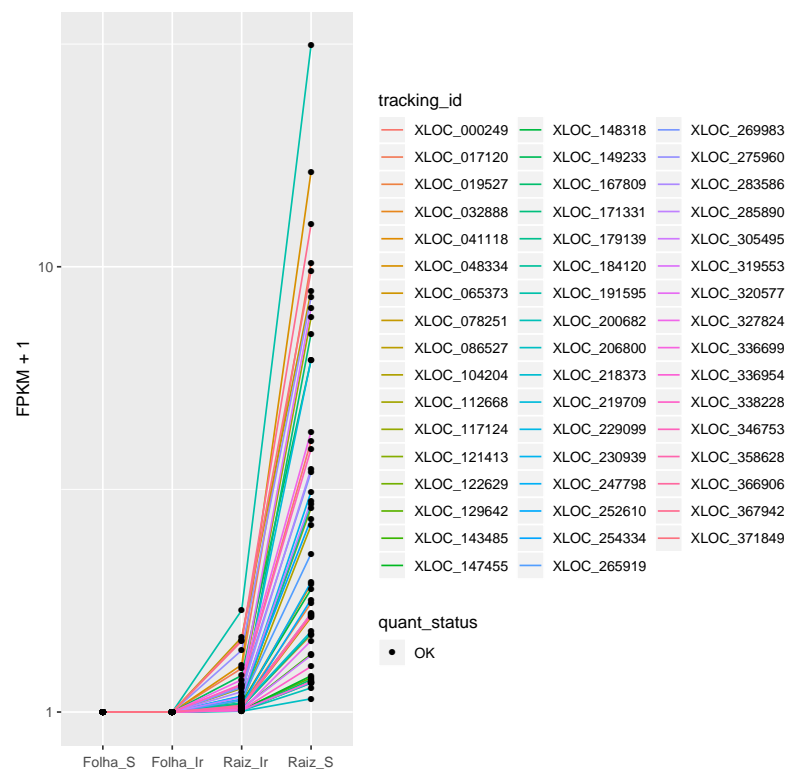

Figura 4.12: Genes co-expressos com gene ScSuSy3 no transcriptoma de SP80-3280. Dados do transcriptoma de cana-de-acúcar de SP80-3280 sob estresse hídrico. Apresentação de 49 genes com expressão similar ao gene ScSuSy3 (87824.2 | XLOC_167809) Linhas: Identificador dos genes no Genescpace de SP80-3280. Colunas: Amostras avaliadas no ensaio de Raiz e Folha. 


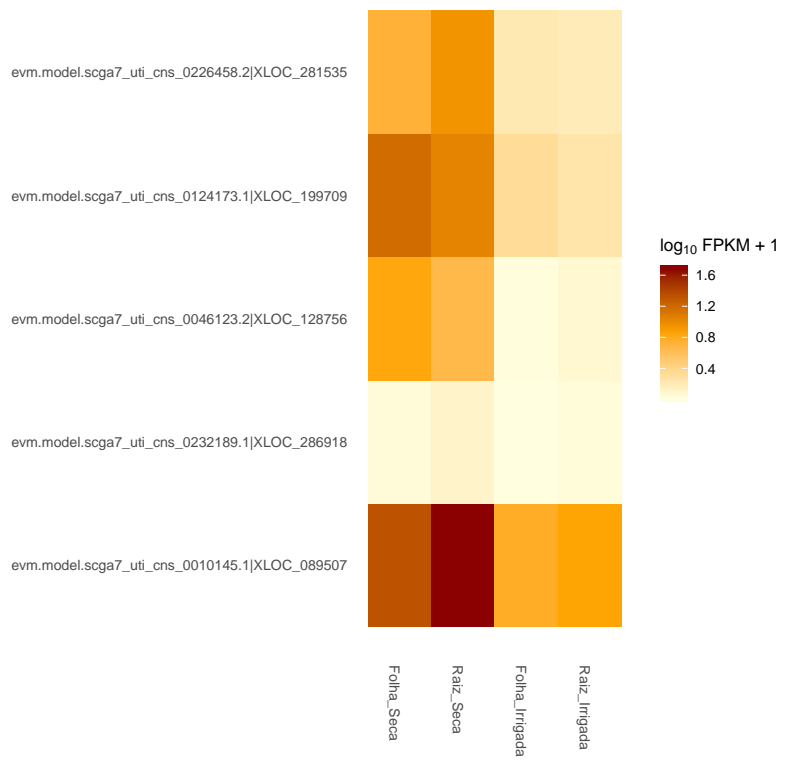

Figura 4.13: Expressão da família gênica ScSuSy4 no transcriptoma de SP80-3280. Expressão gênica de sequências homeólogas da família de genes ScSuSy4 no transcriptoma de cana-de-açúcar SP80-3280 sob estresse hídrico. Linhas: Identificador dos genes no Genescpace de SP80-3280. Colunas: Amostras avaliadas no ensaio de Raiz e Folha.

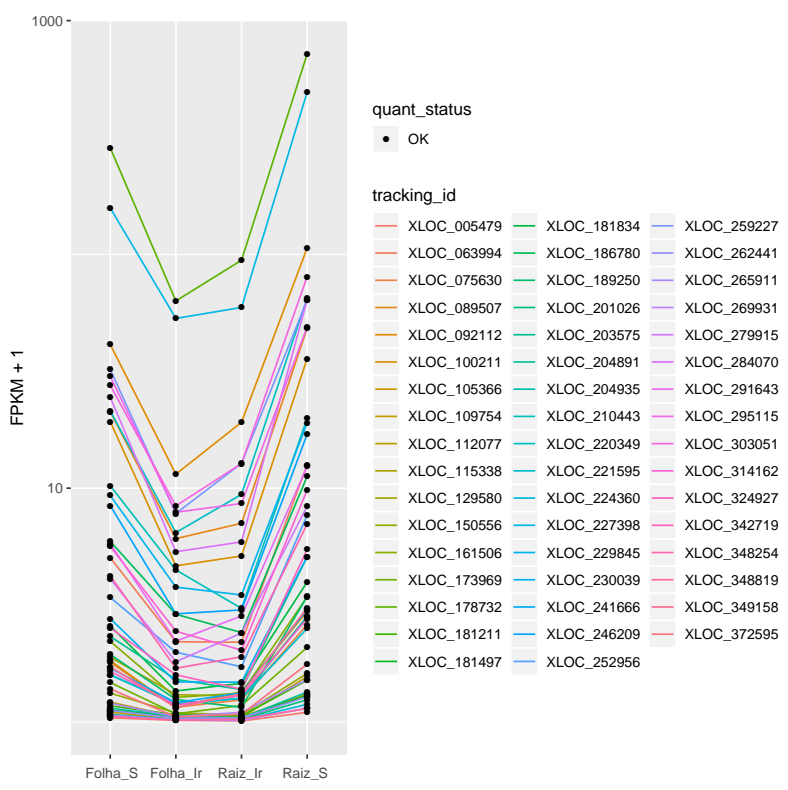

Figura 4.14: Genes co-expressos com gene ScSuSy4 no transcriptoma de SP80-3280. Dados do transcriptoma de cana-de-açúcar de SP80-3280 sob estresse hídrico. Apresentação de 49 genes com expressão similar ao gene ScSuSy4 (10145.1 | XLOC_089507) Linhas: Identificador dos genes no Genescpace de SP80-3280. Colunas: Amostras avaliadas no ensaio de Raiz e Folha. 


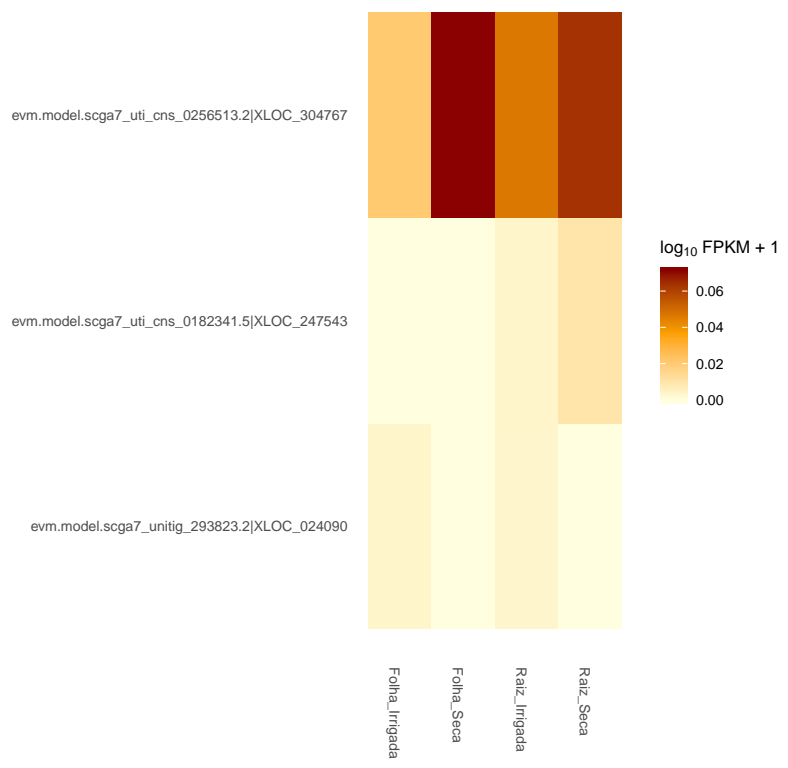

Figura 4.15: Expressão da família gênica ScSuSy5 no transcriptoma de SP80-3280. Expressão gênica de sequências homeólogas da família de genes $S c S u S y 5$ no transcriptoma de cana-de-açúcar SP80-3280 sob estresse hídrico. Linhas: Identificador dos genes no Genescpace de SP80-3280. Colunas: Amostras avaliadas no ensaio de Raiz e Folha.

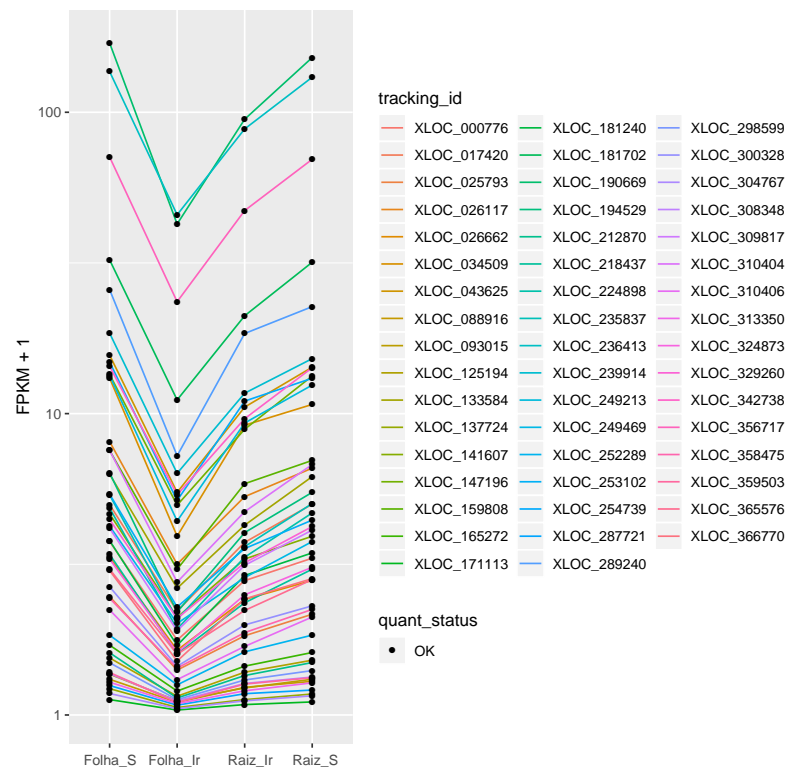

Figura 4.16: Genes co-expressos com gene ScSuSy5 no transcriptoma de SP80-3280. Dados do transcriptoma de cana-de-açúcar de SP80-3280 sob estresse hídrico. Apresentação de 49 genes com expressão similar ao gene ScSuSy5 (256513.2 | XLOC_304767) Linhas: Identificador dos genes no Genescpace de SP80-3280. Colunas: Amostras avaliadas no ensaio de Raiz e Folha. 


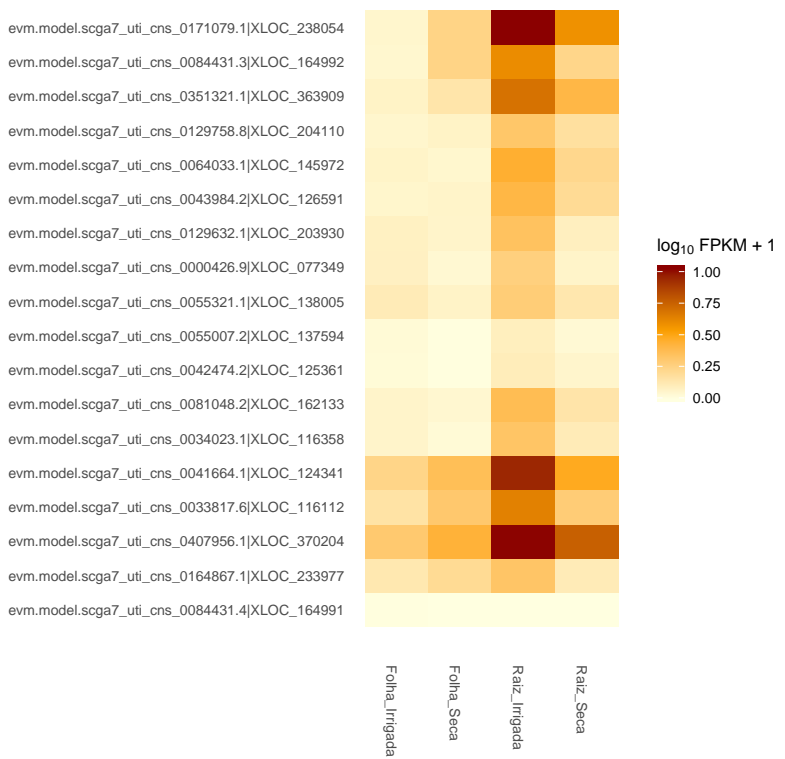

Figura 4.17: Expressão da família gênica ScPAL1 no transcriptoma de SP80-3280. Expressão gênica de sequências homeólogas da família de genes $S c P A L 1$ no transcriptoma de cana-de-açúcar SP80-3280 sob estresse hídrico. Linhas: Identificador dos genes no Genescpace de SP80-3280. Colunas: Amostras avaliadas no ensaio de Raiz e Folha.

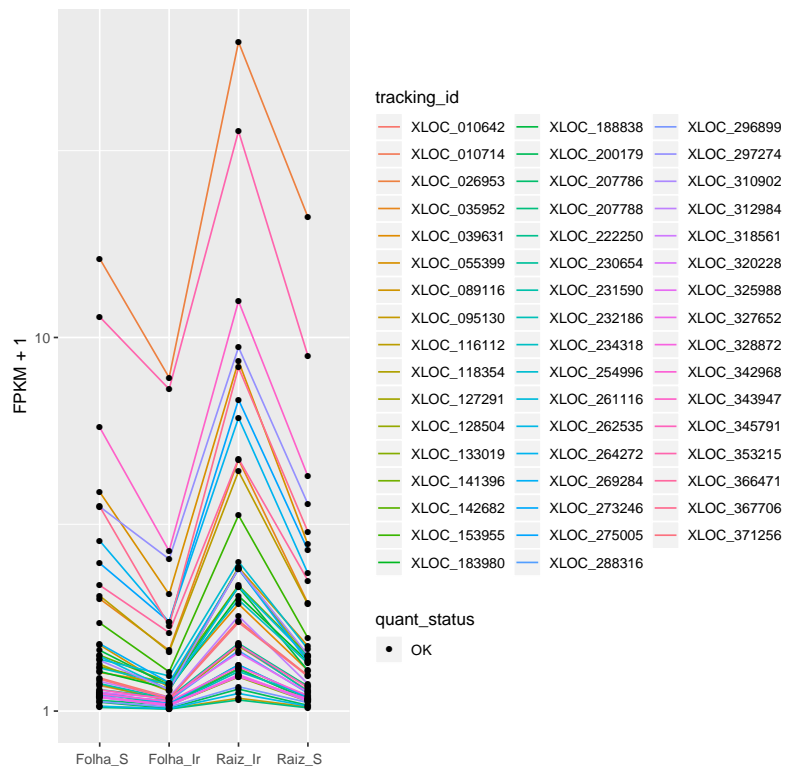

Figura 4.18: Genes co-expressos com gene ScPAL1 no transcriptoma de SP80-3280. Dados do transcriptoma de cana-de-acúcar de SP80-3280 sob estresse hídrico. Apresentação de 49 genes com expressão similar ao gene ScPAL1 (33817.6 | XLOC_116112) Linhas: Identificador dos genes no Genescpace de SP80-3280. Colunas: Amostras avaliadas no ensaio de Raiz e Folha. 


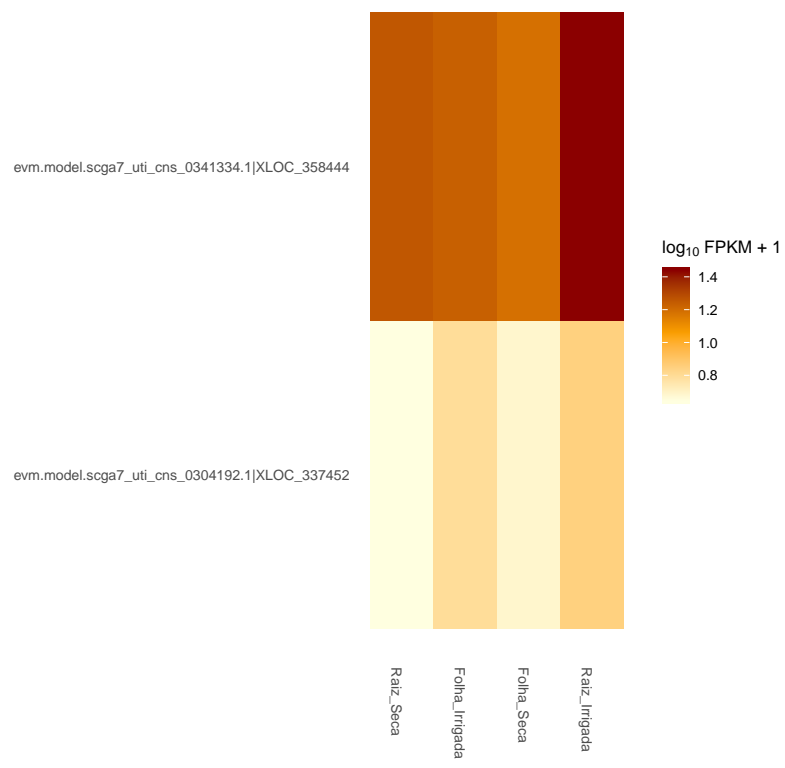

Figura 4.19: Expressão da família gênica ScPAL2 no transcriptoma de SP80-3280. Expressão gênica de sequências homeólogas da família de genes ScPAL2 no transcriptoma de cana-de-açúcar SP80-3280 sob estresse hídrico. Linhas: Identificador dos genes no Genescpace de SP80-3280. Colunas: Amostras avaliadas no ensaio de Raiz e Folha.

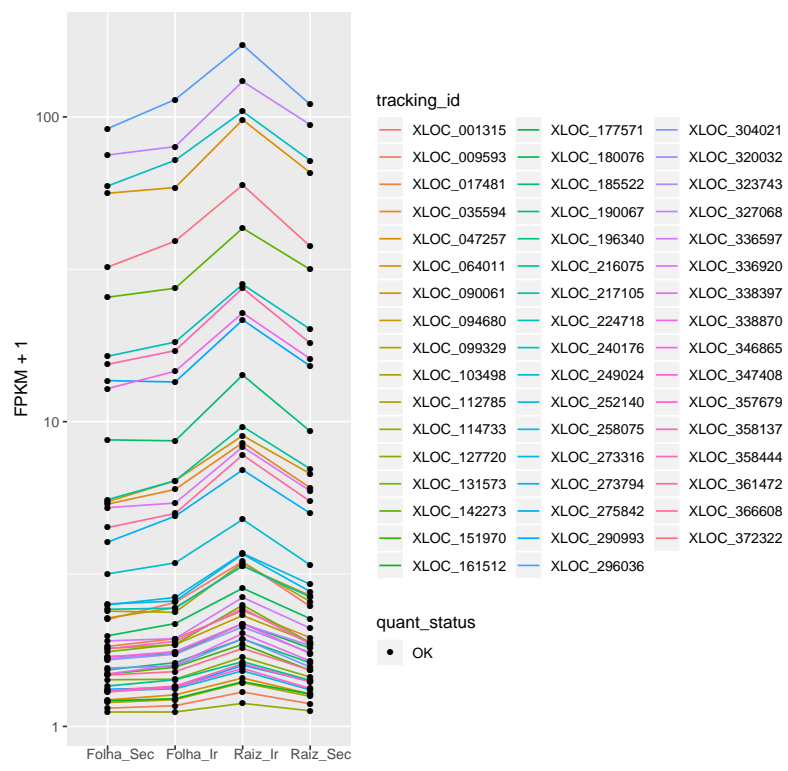

Figura 4.20: Genes co-expressos com gene ScPAL2 no transcriptoma de SP80-3280. Dados do transcriptoma de cana-de-acúcar de SP80-3280 sob estresse hídrico. Apresentação de 49 genes com expressão similar ao gene ScPAL2 (341334.1 | XLOC_358444) Linhas: Identificador dos genes no Genescpace de SP80-3280. Colunas: Amostras avaliadas no ensaio de Raiz e Folha. 


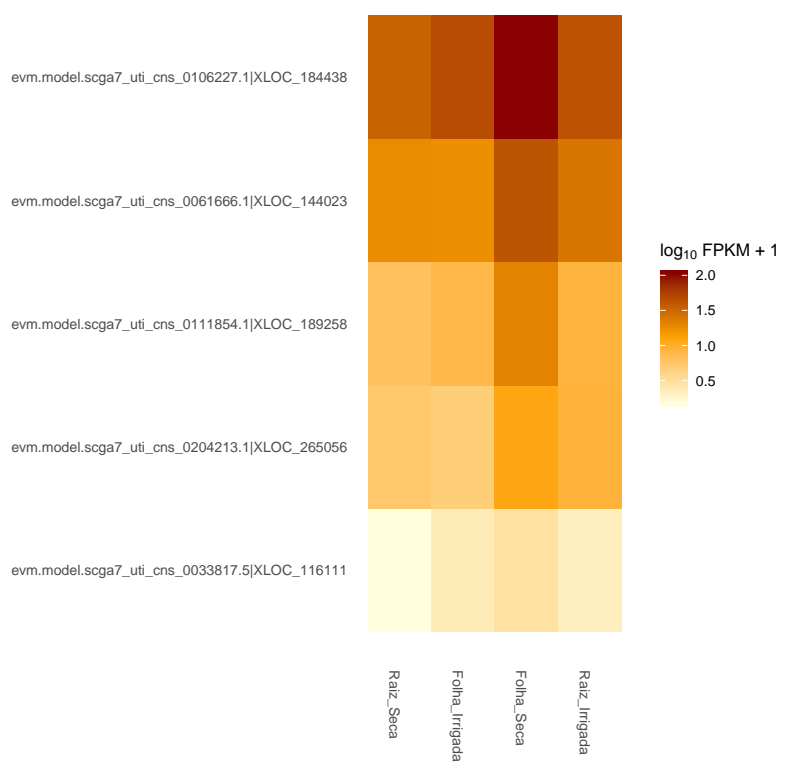

Figura 4.21: Expressão da família gênica ScPAL3 no transcriptoma de SP80-3280. Expressão gênica de sequências homeólogas da família de genes $S c P A L 3$ no transcriptoma de cana-de-açúcar SP80-3280 sob estresse hídrico. Linhas: Identificador dos genes no Genescpace de SP80-3280. Colunas: Amostras avaliadas no ensaio de Raiz e Folha.

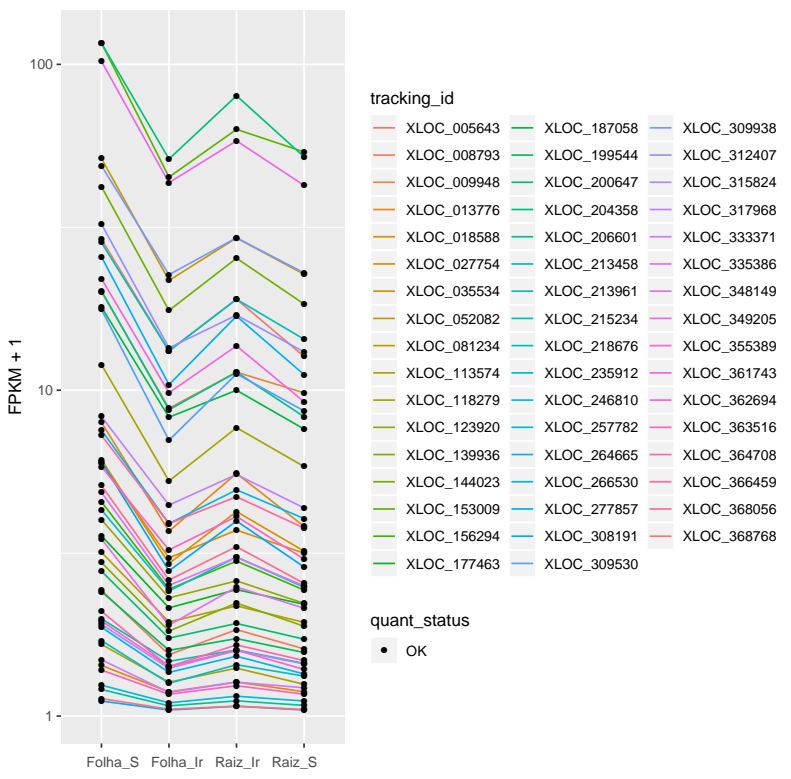

Figura 4.22: Genes co-expressos com gene ScPAL3 no transcriptoma de SP80-3280. Dados do transcriptoma de cana-de-acúcar de SP80-3280 sob estresse hídrico. Apresentação de 49 genes com expressão similar ao gene ScPAL3 (61666.1 | XLOC_144023) Linhas: Identificador dos genes no Genescpace de SP80-3280. Colunas: Amostras avaliadas no ensaio de Raiz e Folha. 


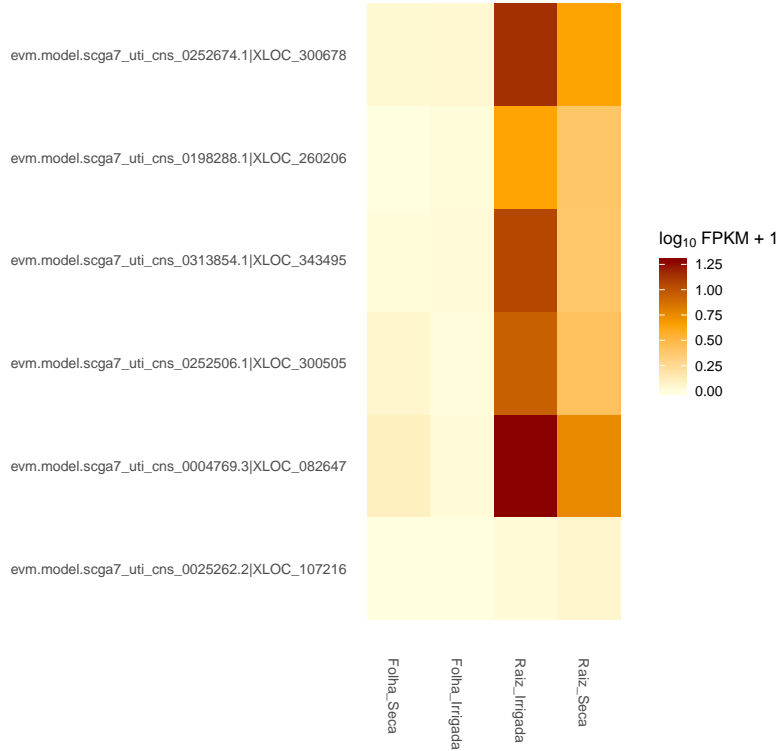

Figura 4.23: Expressão da família gênica ScPAL4 no transcriptoma de SP80-3280. Expressão gênica de sequências homeólogas da família de genes ScPAL4 no transcriptoma de cana-de-açúcar SP80-3280 sob estresse hídrico. Linhas: Identificador dos genes no Genescpace de SP80-3280. Colunas: Amostras avaliadas no ensaio de Raiz e Folha.

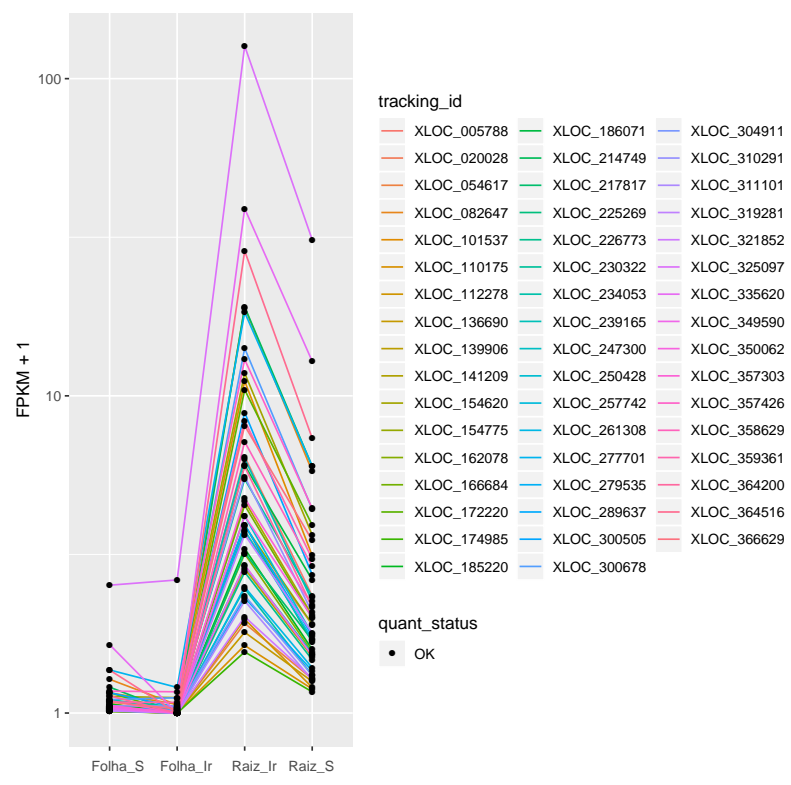

Figura 4.24: Genes co-expressos com gene ScPAL4 no transcriptoma de SP80-3280. Dados do transcriptoma de cana-de-acúcar de SP80-3280 sob estresse hídrico. Apresentação de 49 genes com expressão similar ao gene ScPAL4 (4769.3 | XLOC_082647) Linhas: Identificador dos genes no Genescpace de SP80-3280. Colunas: Amostras avaliadas no ensaio de Raiz e Folha. 


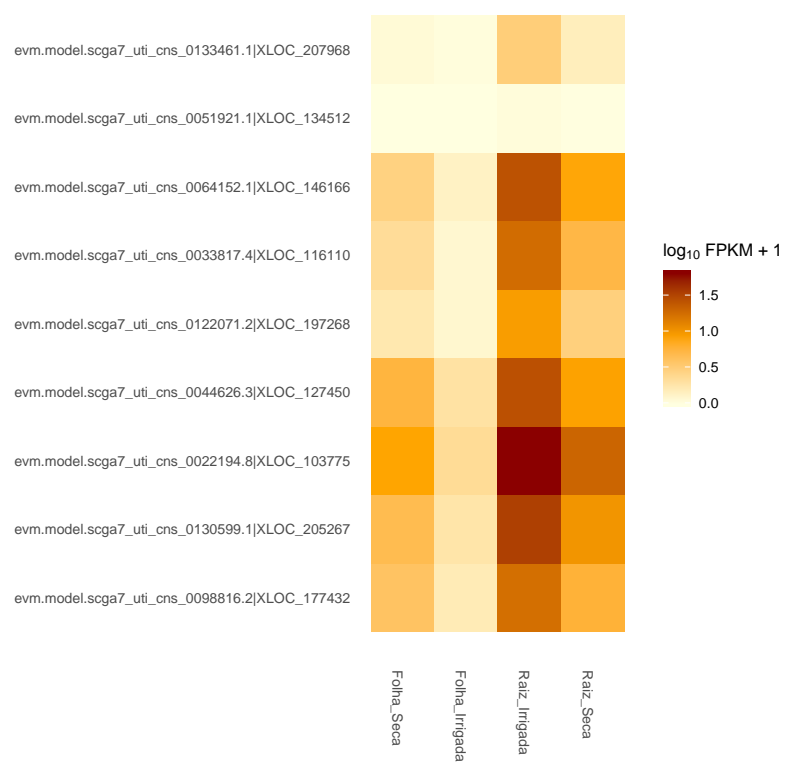

Figura 4.25: Expressão da família gênica ScPAL5 no transcriptoma de SP80-3280. Expressão gênica de sequências homeólogas da família de genes $S c P A L 5$ no transcriptoma de cana-de-açúcar SP80-3280 sob estresse hídrico. Linhas: Identificador dos genes no Genescpace de SP80-3280. Colunas: Amostras avaliadas no ensaio de Raiz e Folha.

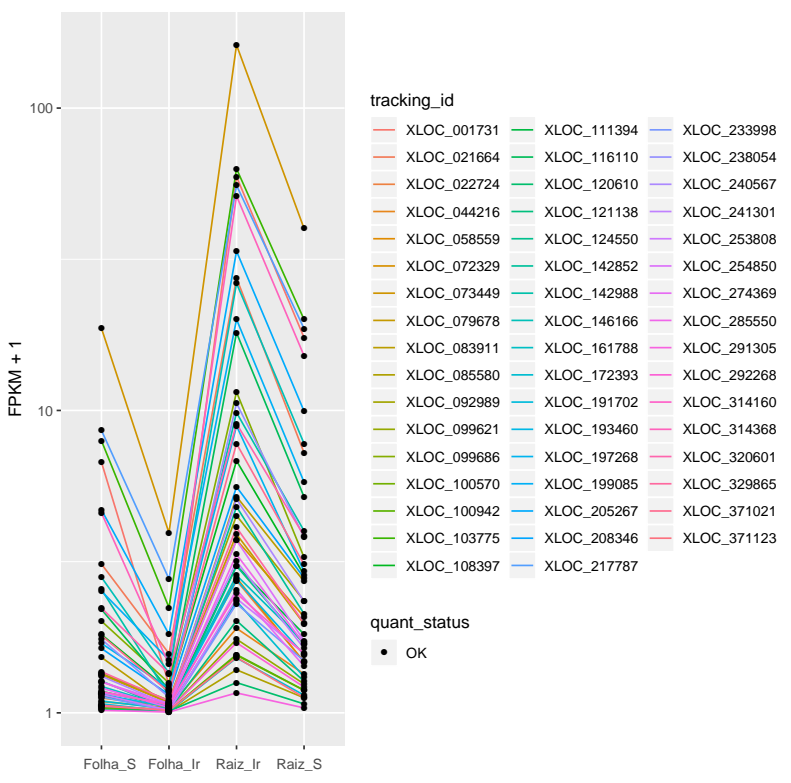

Figura 4.26: Genes co-expressos com gene ScPAL5 no transcriptoma de SP80-3280. Dados do transcriptoma de cana-de-acúcar de SP80-3280 sob estresse hídrico. Apresentação de 49 genes com expressão similar ao gene ScPAL5 (22194.8 | XLOC_103775) Linhas: Identificador dos genes no Genescpace de SP80-3280. Colunas: Amostras avaliadas no ensaio de Raiz e Folha. 
20

15

$\% \quad 10$

5

0 (1)

15

,

\section{A. thaliana}

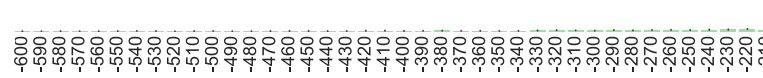
- nucleotídeós

$\% \quad 10$

5

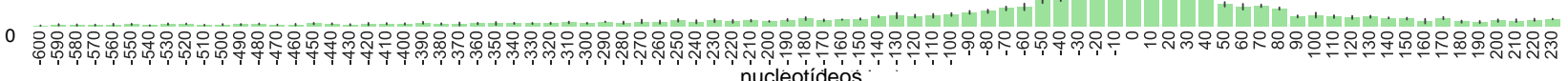
20 15 H. sapiens

$\% \quad 10$

5

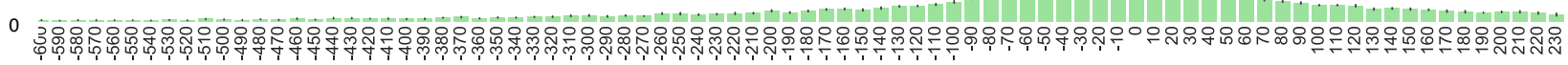
nucleotídeos

\section{S. cerevisiae}

15

$\stackrel{\circ}{10}$

5

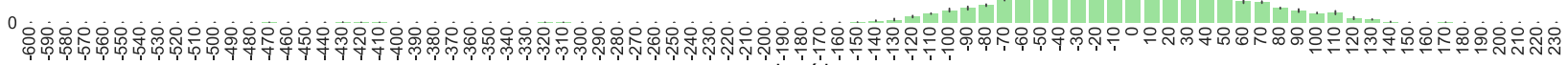
20

O. sativa núcleotídeos

15

$\% \quad 10$

5

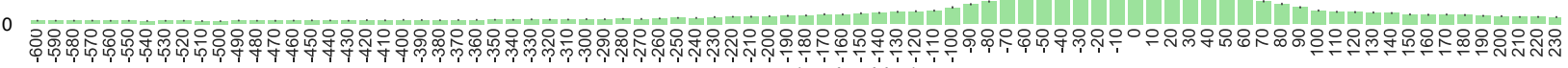
nucleotídeos

Figura 4.27: Histograma de predição do TSSFinder para diferentes organismos Histograma de distância do sinal de TSS identificado pelo TSSFinder em relação ao sinal de TSS validado. Eixo vertical representa a porcentagem de predição correta e eixo horizontal o intervalo de nucleotídeos. O desvio padrão é indicado em cada intervalo. Créditos: Ígor Bonadio. 


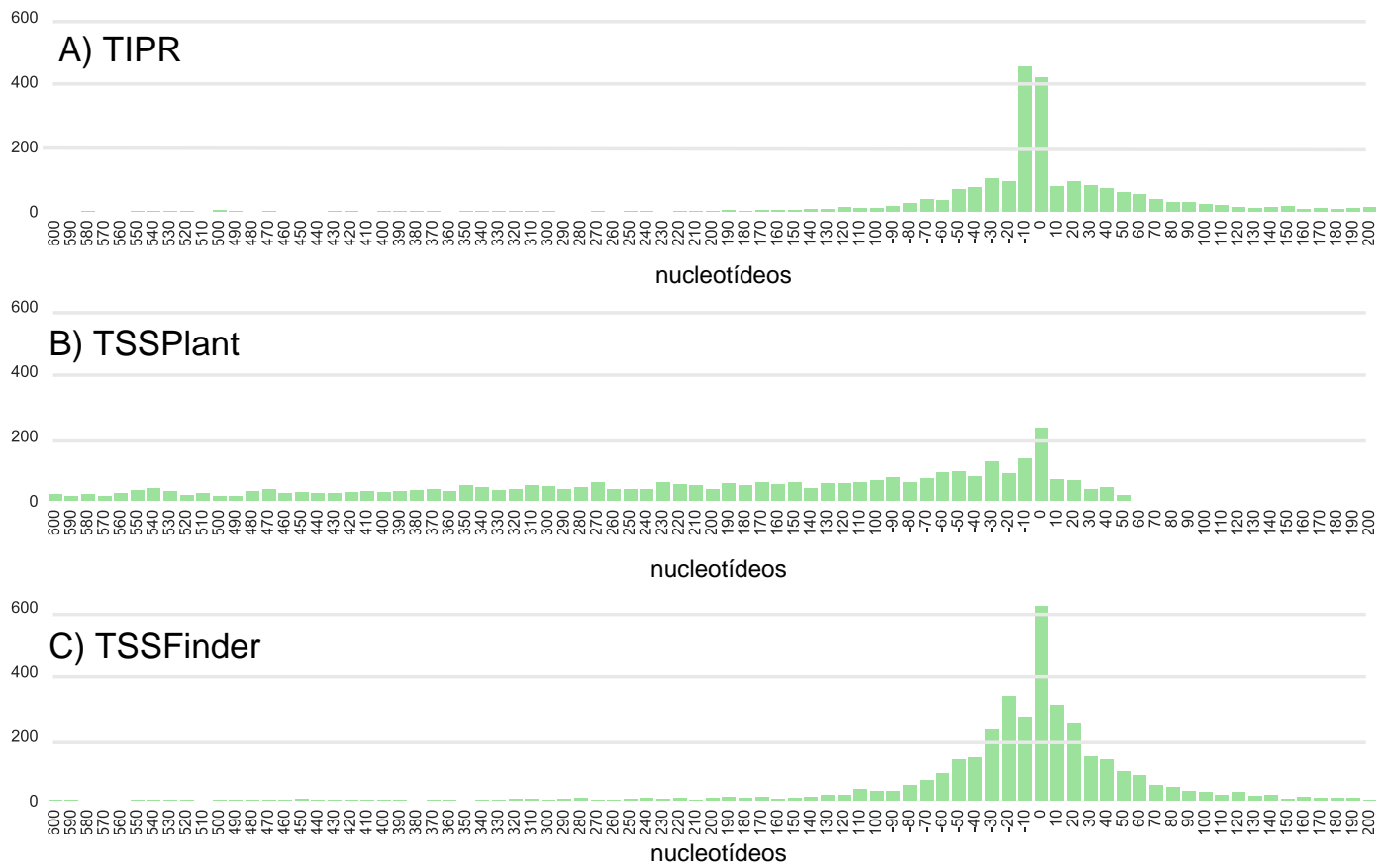

Figura 4.28: Histograma de predição de TSS nas ferramentas TIPR, TSSPlant e TSSFinder Histograma de distância do sinal de TSS identificado pelo TSSFinder em relação ao sinal de TSS validado. Eixo vertical representa o número de predição correta e eixo horizontal o intervalo de nucleotídeos. A) TIPR, B) TSSPlant, C) TSSFinder. Créditos: Ígor Bonadio. 


\section{Capítulo 5}

\section{Discussão}

\subsection{Análise da região Promotora em cana-de-açúcar}

\subsubsection{Sugarcane drought-responsive 1 - Scdr1}

Atualmente a disponibilidade de água é o principal obstáculo para manutenção da produtividade agrícola sustentável. O desenvolvimento de culturas adaptadas à condições hídricas é primordial para desenvolvimento de novas variedades de plantas. Como exemplo, plantas de cana-de-açúcar podem suportar períodos de escassez de água durante o estágio final de maturação da cultura, entretanto, é neste estágio onde ocorre o maior acúmulo de sacarose. Porém, caso o período de escassez de água é prolongado nesta etapa de desenvolvimento a capacidade de resiliência da planta pode ser superada e assim causar perdas severas na produtividade [Begcy et al., 2012].

Em 2012, Begcy et al. apresentaram o gene Scdr1 (sugarcane drought-responsive 1) como principal fator para desenvolvimento de plantas de cana-de-açúcar resistentes à seca. Estes gene codifica uma proteína de 248 aminoácidos com elevado número de resíduos de prolina (19\%) e cisteína (13\%). O gene Scdr1 foi identificado, inicialmente, em cana-de-açúcar através do transcriptoma de plantas sensíveis a estresse hídrico [Lembke, 2013].

Em seguida o gene $S c d r 1$ foi caracterizado através da expressão heteróloga em Tabaco e as plantas de Tabaco que receberam este gene adquiriram maior tolerância à seca, salinidade e estresse oxidativo [Begcy et al., 2012]. Ademais, os parâmetros fisiológicos como taxa de transpiração, fotossíntese líquida, condutância estomática e concentração interna de $\mathrm{CO}_{2}$ foliar foram menos afetados pelos estímulos abióticos em plantas de tabaco com expressão heteróloga $S c d r 1$ do que em plantas de tabaco tipo selvagem [Begcy et al., 2012].

Porém, nestes dois ensaios, a região Promotora do gene $S c d r 1$ não foi avaliada. Além disso, nos trabalhos de Begcy et al. [2012] e Lembke [2013] o nível de poliploidia do genoma de cana-de-açúcar também não foi considerado. Esta observação pode estar associada a falta do genoma de referência ou de conjunto de dados genômicos para cana-de-açúcar; como o Genespace de cana-de-açúcar SP80-3280 (Souza, GM, et al 2018 - manuscrito em revisão).

De acordo com os autores, o gene $S c d r 1$ pode conferir tolerância a múltiplos estímulos 
abióticos associados à restrição hídrica e este gene tem elevado potencial biotecnológico para aplicação na agricultura [Begcy et al., 2012]. Embora a expressão do gene Scdr1 em diferentes variedades de cana-de-açúcar não apresentar associação com a tolerância à seca de forma mais nítida [Begcy et al., 2012].

Este fato pode estar associado com os mecanismos de regulação gênica que este gene está sujeito nas diferentes variedades de plantas de cana-de-açúcar e por isso é fundamental o conhecimento destes mecanismos; em especial o processo de regulação gênica. Ademais devido a poliploidia do genoma de cana-de-açúcar é esperado que cada gene apresente diferentes cópias no genoma e consequentemente regiões regulatórias distintas [Thirugnanasambandam et al., $2018]$

No trabalho atual nós identificamos as diferentes cópias putativas do gene $S c d r 1$ no $G e$ nespace de cana-de-açúcar SP80-3280. Além disso, a caracterização da região Promotora dos respectivos homeólogos do gene $S c d r 1$ foram realizadas. Tanto a identificação dos homeólogos do gene $S c d r 1$ quanto a análise da região Promotora foram executados in silico.

A literatura indica que o genoma de plantas de cana-de-açúcar modernas podem apresentar diferentes número de homeólogos uma vez que este genoma tem origem alopoliplóide e aneuplóide (o genoma constituído a partir de duas espécie diferentes poliplóides) [Vilela et al., 2017]. Talvez, para cana-de-açúcar SP80-3280 seja essa razão de recuperar 13 sequências de DNA similares a sequência de DNA codificante do gene Scdr1.

Após a identificação dos homeólogos em SP80-3280 a região a montante de cada cópia foi isolada com no máximo 1500 nt de distância a partir do início da região codificante. O valor de 1500 nt é o número mais comum na análise in silico da região Promotora [de los Reyes et al., 2015, Meier et al., 2008, Mejía-Guerra et al., 2015]. Com este tamanho é possível realizar a caracterização da região Promotora através da rotulação de duas subsequências: i) Core Promoter (500 nt); ii) Promotor Proximal (1000 nt). Além disso, esse tamanho é extremamente útil quando a caracterização da região Promotora é realizada em genomas sem o TSS anotado e consequentemente sem nenhuma estimativa do tamanho da região 5'UTR.

Usando essa configuração, o nosso trabalho conseguiu rotular a região Core Promoter de 7 sequências de DNA como TATA-less. O tamanho médio da região 5'UTR foi de 220 nt e este tamanho está na faixa esperada para plantas [de los Reyes et al., 2015, Dreos et al., 2016, Mejía-Guerra et al., 2015]. Em geral, a classe TATA-less foi associada com genes expressos em raiz de plantas de cana-de-açúcar SP80-3280 quando submetidas a estresse hídrico. Por outro lado, classe TATA-box foi associada a sequência do gene $S c d r 1$ mais expressa na condição irrigada. Para classe TATA-less foi possível identificar, na região Promotora Proximal, 6 TFBSs diferentes. Estes TFBS apresentaram associação com quatro TFs responsivos a fitohormônio ABA. Apesar da existência de 2 TFBSs associados a um único TF, este resultado já foi observado anteriormente em Arabidopsis [Franco-Zorrilla et al., 2014]. A observação deste resultado pode sinalizar que a região Promotora Proximal do gene Scdr1 apresenta interações TF-TFBS de alta afinidade e interações TF-TFBS com baixa afinidade. Essa hipótese é reforçada pois em 6 sequências foi apresentado que cinco dos seis 
TFBS estão agrupados na mesma região da sequência de DNA, além disso estes TFBSs estão organizados com espaço médio entre eles de 35 nt. Como já observado na literatura, a principal função do TFBS de baixa afinidade é recrutar o TF para região desejada para que em seguida a interação TF e TFBS de alta afinidade ocorra [Franco-Zorrilla et al., 2014, Franco-Zorrilla and Solano, 2017]. Essa cooperação entre TFBSs é esperada principalmente em regiões da sequência de DNA onde TFs com mesma função regulatória apresentam sítios de ligação agrupados [Meier et al., 2008, Schultheiss et al., 2009]. Esse tipo de configuração para região Promotora foi observada em seis sequências do gene Scdr1.

Considerando apenas este resultado, podemos estimar que as classes de TFs AP2/ERF, WRKY e NAC são essenciais para o processo de regulação do gene Scdr1. Além disso, podemos esperar que a organização destes TFBSs na região Promotora pode favorecer a ligação do TF com sequência de DNA mesmo em condições adversas onde a afinidade TFTFBS pode ser reduzida.

Presente em 9 sequências, a classe de TF Myb não foi associada com nenhum agrupamento de TFBS e sempre apresentou espaçamento entre o TFBS vizinho superior a $150 \mathrm{nt}$. Essa características pode indicar que este TF tem atuação isolada no processo de regulação do gene $S c d r 1$ uma vez que para 2 sequências este foi o único TFBS encontrado.

\subsubsection{Sugarcane Sucrose Synthase (ScSuSy)}

Em plantas a família de genes SuSy catalisam a decomposição reversível da sacarose em UDP-glicose e frutose [Zhang et al., 2013]. Este grupo de genes têm papel fundamental para o processo de partição de carbono através do controle do nível de sacarose na células. Recentemente variedade de cana-de-açúcar SP80-3280 teve seu espaço genômico sequenciado e a análise filogenética desse grupo de genes foi realizado contra a região codificante de genes SuSy de plantas de sorgo (Souza, GM, et al 2018 - manuscrito em revisão). Com esta análise foi possível encontrar 44 sequências relacionadas com a família de genes $S u S y$ em cana-deaçúcar SP80-3280. Além disso, nessa análise observou-se que cana-de-açúcar possui 5 grupos de genes SuSy (ScSuSy1-5) organizados em três clados: I (ScSuSy1 e 2), II (ScSuSy3 e 5) e III (ScSuSy4) (Souza, GM, et al 2018 - manuscrito em revisão). Através do ORFome de cana-de-açúcar foi possível constatar que 36 dos 44 membros do ScSuSy estavam expressos [Nishiyama et al., 2014]. Ademais a expressão destes genes foi mais acentuada nos colmos de cana-de-açúcar (entrenó maturo e imaturo) do que na região foliar das plantas analisadas. Os resultados observados sugerem que os grupos ScSuSy1, ScSuSy2 e ScSuSy5 podem estar envolvidos na partição de carbono na região dos entrenós de cana-de-açúcar, assim como no gerenciamento do fluxo de carbono entre fonte e dreno [Zhang et al., 2013]. Para os 44 membros da família de genes ScSuSy nós analisamos as regiões Core Promoter e Promotor Proximal (Souza, GM, et al 2018 - manuscrito em revisão).

A região Promotora das famílias $S c S u S y 3$ e $S c S u S y 5$ apresentaram classificação da região Core Promoter similar (classe TATA-box) e apesar dos TFBSs identificados em cada 
família ser diferentes, os dois motivos foram associados com o mesmo processo de regulação: via de sinalização ABA [Khan et al., 2017]. Além disso, as análises de dois transcriptomas relacionados com SP80-3280 para os tecidos de raiz, folha (projeto FAPESP 2013/13659-0), entrenó1 e entrenó5 de SP80-3280 [Nishiyama et al., 2014] demonstram que estes genes apresentam expressão responsiva à seca além de tecido específica. As duas famílias apresentaram expressão diferencial na condição de Raiz Seca, porém apenas a famíla ScSuSy5 apresentou expressão diferencial na condição Folha Seca e nos tecidos Entrenó1, Entrenó5 de cana-deaçúcar SP80-3280. Este resultado pode justificar a particularidade da região Promotora da família ScSuSy5 de não compartilhar TFBSs identificados nas outras famílias de genes ScSuSy. De fato o gene $S c S u S y 5$ foi o único grupo de genes $S c S u S y$ a apresentar expressão significativa em diferentes tecidos de cana-de-açúcar.

O comportamento observado na família $S c S u S y 5$ também é encontrado nas família $S c$ SuSy2, entretanto essa família apresentou região Promotora TATA-less e seu TFBS foi associado com o transporte e metabolismo de açúcar [Khan et al., 2017]. Além disso, 4 sequências homeólogas da família $S c S u S y 2$ estavam expressas significativamente indicando que esta família pode ter expressão constitutiva; em acordo com a sua região Promotora TATA-less [Kumari and Ware, 2013].

Por outro lado a família $S c S u S y 3$ apresentou o maior número de TBFSs compartilhados com as outras famílias; em especial $S c S u S y 1$ e $S c P A L 3$. Além disso, essa família de genes foi expressa apenas em Raiz Seca e aparentemente essa família não apresentou expressão gênica significativa em outros tecidos. De acordo com os TFBSs REV1, ABF3 e PBF [Khan et al., 2017] mapeados nessa família e com os dados de expressão é possível esperar que a família ScSuSy3 esteja mais associada com respostas à seca [Kumari and Ware, 2013].

A família $S c S u S y 1$ apresentou expressão significativa nos tecidos de Raiz, entrenó1 e entrenó2. Em Raiz, esta família foi diferencialmente expressa na condição Irrigada. O TFBS identificado nessa família foi associado com a integração de redes de regulação do relógio circadiano com os genes da via de sinalização do fitohormônio Auxina [Kumari and Ware, 2013]. Esta característica pode explicar o comportamento da expressão gênica dessa família em Raiz em nos tecidos de entrenó.

A família $S c S u S y 4$ apresentou expressão diferencial apenas nas amostras de Raiz Seca e Folha Seca. Nessa família o TFBS predito foi associado com a integração com regulação de genes envolvidos com o fotoperíodo [Kumari and Ware, 2013]. Além disso, na região Promotora dessa família, foram mapeados TFBS associados com genes envolvidos com respostas a estresse abiótico e a transdução de sinal via glicose [Kumari and Ware, 2013]. Esta característica pode explicar o comportamento da expressão gênica dessa família em Raiz e Folha sob condições de estresse hídrico. 


\subsubsection{Sugarcane phenylalanine ammonia-lyase $(S c P A L)$}

O interesse na conversão de compostos lignocelulósicos em produtos químicos ou em combustíveis tem despertado grande interesse da indústria. Portanto a definição dos membros da via de biossíntese de fenilpropanóides em cana-de-açúcar é de grande relevância para agronegócio brasileiro e para indústria de biocombustível [Ferreira et al., 2016]. A fenilalanina amônia-liase (PAL) é o primeiro gene envolvido com a biossíntese de fenilpropanóides e este grupo químico está relacionado indiretamente com a formação da parede celular de plantas [Ferreira et al., 2016]. A parede celular é o principal receptor para acúmulo de carboidratos nas plantas, no entanto, o carbono armazenado nessa molécula não está disponível prontamente e a justificativa para essa indisponibilidade do carboidrato armazenado na parede celular é a presença de lignina [Ferreira et al., 2016]. Assim a identificação dos mecanismos relacionados com produção e armazenamento de lignina são fundamentais para alavancar a produção de Etanol de segunda geração. Através do mapeamento de proteínas previstas no espaço genômico de cana-de-açúcar SP80-3280 contra o conjunto de genes associados a parede celular descrito no Catálogo Cell Wall do SUCEST-FUN foi possível identificar 47 homeólogos putativos para os genes ScPAL [Ferreira et al., 2016]. Estes 47 homeólogos foram agrupados em 5 grupos (PAL1-5) e para cada grupo havia pelo menos um ortólogo em plantas de Sorgo (artigo em submissão). Para cada um dos 47 membros da família ScPAL nós analisamos as regiões Core Promoter e Promotor Proximal (Souza, GM, et al 2018 manuscrito em revisão).

As famílias $S c P A L 5 a$ e $S c P A L 5 b$ apresentaram expressão maior nas amostras de Raiz e entrenós. Além disso, estas duas famílias foram mais expressas nas amostras de Raiz irrigada. Apesar dos TFBSs identificados nestas duas famílias apresentarem relação com a via de sinalização ABA [Khan et al., 2017], as duas famílias foram reprimidas. Este comportamento pode indicar que estes TFBS na região Promotora das famílias ScPAL5a e ScPAL5b atuam como repressores da transcrição. De fato, para a maioria das sequências, a classificação para a região Promotora foi TATA-less e essa região regulatória está associada com genes constitutivos Kumari and Ware [2013]. Além disso os TBFSs preditos nestas duas famílias foram localizados em mais de uma sequência de DNA e este tipo de organização pode favorecer o processo de regulação [Kumari and Ware, 2013]. Esse comportamento também foi observado na família $S c P A L 1$, no entanto, o TBFS predito nesta família foi associado com a regulação de genes responsivos a estresse abiótico além de potencializar a a transdução de sinal via glicose [Khan et al., 2017].

Curiosamente a família ScPAL3 apresentou expressão mais significativa nas amostras de Folhas Seca. Essa diferença pode estar associada com o TFBS predito nesta família. Nessa família o TFBS GGTCsGGCkC foi associado com o elemento AP2/ERF que responsivo à seca [Khan et al., 2017]. Entretanto, a diferença entre a família ScPAL3 e as outras está no processo de regulação exercido pelo TFBS que neste caso foi associado a ativação da expressão gênica [Khan et al., 2017]. De fato, 80\% das sequências homeólogas da famíla 
ScPAL3 foram expressas constitutivamente nas outras condições; embora em menor escala do que nas amostras de Folha Seca.

\subsection{Análise da região Promotora de genes co-expressos}

Nós construímos grupos de genes co-expressos em todos os transcriptomas e cada grupo apresentou sequências únicas. Entretanto, na análise da região Promotora dos genes coexpressos os TFBSs ScSuSy1, ScSuSy4 e ScPAL1 foram identificados em mais de $40 \%$ sequências de cada grupo. Este cenário foi similar entre todos transcriptomas.

Para o TFBS de ScSuSy1 aproximadamente $60 \%$ das sequências regulatórias dos genes co-expressos nos grupos ScSuSy1,ScSuSy3, Scdr1, ScPal1, ScPal2, Pal5a, e ScPal5b foram mapeadas. Para o TFBS de ScSuSy4 aproximadamente $40 \%$ das sequências regulatórias dos genes co-expressos nos grupos ScSuSy3, ScSuSy4 e ScPAL5b. E o grupo ScPal1 aproximadamente $40 \%$ das sequências regulatórias de todos grupos de genes co-expressos foram mapeados. Apesar dessa diferença, estes TFBS mapearam dois grupos de genes co-expressos comuns: $S c S u S y 3$ e $S c P A L 5 b$.

A cobertura destes TFBSs pode indicar que os TFs das classes HLH (ScSuSy1), MADS box factors $\left(S c S u S y_{4}\right)$ e bZIP $(S c P A L 1)$ são preponderantes para o processo de regulação nestes grupos [Khan et al., 2017]. Além disso, estes genes podem auxiliar na construção de redes regulatórias de genes envolvidos com o metabolismo de açúcar e síntese de parede celular.

Apesar de simplória a ideia, é possível esperar que o grupo de genes $S c S u S y 3$ e $S c P A L 5 b$ atuem como mediadores entre os grupos ScSuSy1, ScSuSy4 e ScPAL1. Entretanto, novas análises devem ser realizadas para enfim detectar possíveis ligações entre estes grupos.

\subsection{TSSFinder - preditor $a b$ initio do sinal de TSS em eucariotos}

Neste trabalho nós desenvolvemos uma nova ferramenta de predição para o sítio TSS visando aprimorar o processo de localização da região promotora assim como elevar a confiabilidade da caracterização in silico da região Core Promoter. O desenvolvimento da ferramenta foi orientada para os organismos Arabidopsis thaliana, Oryza sativa, Drosophila melanogaster, Homo sapiens, Saccharomyces cerevisiae, Schizosaccharomyces pombe e Gallus gallus. O conjunto de sequências de DNA destes organismos foi utilizado apenas para o treinar e validar a ferramenta de predição desenvolvida pelo nosso grupo. O processo de desenvolvimento da ferramenta foi realizado em parceira com o aluno de doutorado em Ciências da Computação Ígor Bonadio e com o Professor Alan Durham.

Nestes organismos a seleção da sequência de DNA não codificante foi suportada por arquivos de anotação do genoma em conjunto com os dados do sinal de TSS validados por 
experimentos biológicos [Dreos et al., 2016, Sakai et al., 2013]. Com exceção de O. sativa, a versão do genoma para cada organismo foi recuperada de acordo com as instruções do banco de dados EPD [Dreos et al., 2016]. Para O. sativa, a versão do genoma foi recuperada de acordo com as instruções do banco de dados RAP-DB [Sakai et al., 2013]. O treinamento e validação da ferramenta TSSFinder foram realizadas com sequências de DNA de $A$. thaliana, O. sativa, D. melanogaster, H. sapiens, S. cerevisiae, S. pombe e G. gallus.

Dessa forma para cada organismo foi gerado um modelo de predição de TSS ab initio. Em seguida a validação do modelo foi executada usando apenas sequências de DNA que não participaram do processo de treinamento do modelo de predição. Em cada organismo, os processos de treinamento e validação do preditor de TSS foram realizados em 5 subgrupos de sequências. Sendo um subgrupo para o treinamento e quatro para validação. O processo de avaliação realizado nesse trabalho é similar a metodologia de aprendizado supervisionado cross-validation através da técnica k-folds. Apesar da similaridade entre as metodologias, o procedimento realizado neste trabalho foi inverso ao proposto pela metodologia crossvalidation onde $90 \%$ do conjunto de dados é utilizado no treinamento e os $10 \%$ remanescentes são usados para testar o modelo. No nosso trabalho apenas $20 \%$ do conjunto de dados foi usado para treinar o modelo e $80 \%$ das sequências foram utilizadas para testar o modelo de predição treinado. Por fim todo processo de treinamento foi executado com sequências de DNA de tamanho não superior a 1500 nt do start códon anotado e para testar os modelos todas sequências de DNA foram isoladas com tamanho de $2000 \mathrm{nt}$.

O TSSFinder é primeiro programa de predição do TSS descrito na literatura que faz uso do modelo probabilístico discriminativo baseado em campos aleatórios condicionais de cadeias lineares (Linear Chain-CRF). Além desse caráter, o TSSFinder é capaz de estimar o tamanho médio da região 5' UTR, classificar a região promotora em TATA-box ou TATA-less, possibilidade de re-treinamento da ferramenta de predição pelo usuário final e apresentação dos resultados de predição no formato bed.

O desempenho do TSSFinder para identificação do sinal de TSS foi superior as ferramentas TIPR [Morton et al., 2015] e TSSPlant [Shahmuradov et al., 2017]. Estas ferramentas, até momento, apresentavam os melhores resultados para identificação do TSS já descritos no literatura. Entretanto, através da nossa avaliação foi possível observar que as duas ferramentas utilizam sequências de DNA com o tamanho fixo. A ferramenta TIPR utiliza sequências de DNA com 5000 nt upstream e downstream do sinal de TSS e a ferramenta TSSPlant utiliza sequências preferencialmente com o tamanho de 251 nt: 200 nt upstream do sinal de TSS e 50 nt downstream do sinal de TSS. A necessidade desse tipo configuração pode ser prejudicial para descoberta ab initio do sinal de TSS em organismos com o genoma não anotado ou para organismos não modelo que não disponham de um genoma de referência.

Ademais, o TSSFinder foi capaz de realizar a predição do TSS em poucos minutos e essa velocidade foi muito superior aos dois modelos avaliados. Essa vantagem é atribuída a dois fatores fundamentais para a nossa ferramenta, a primeira é o número reduzido de características usadas para modelar o problema e a segunda o arcabouço probabilístico 
utilizado para rotular o problema.

Para TIPR, o processo de identificação do TSS é realizado somente após o mapeamento de centenas de PWMs relacionadas com a região Core promoter ou com a região Promotora Proximal. Todo esse processo é realizada para gerar o classificador binário para a região Promotora. O modelo de regressão logística é utilizado no TIPR para classificar o sinal de TSS. Apesar do mecanismo similar a ferramenta TIPR, o modelo TSSPlant utiliza apenas o score de dezenas de PWMs relacionadas com o Core Promoter. Para identificação do sinal de TSS, a ferramenta TSSPlant utiliza o modelo de classificação baseado em redes neurais. Nas duas ferramentas a identificação das diferentes PWMs é fundamental para a rotulação do sinal TSS. Portanto, esse número elevado de características nos dois modelos são preponderantes para morosidade das duas ferramentas.

Por outro lado, o TSSFinder utiliza apenas três características. O sinal de ATG que marca o início da sequência, o sinal de TSS validado por experimentos in vivo - este sinal é utilizado apenas para rotular a região vizinha ao TSS com largura máxima de 6 nt - e por fim o sinal de TATA-box ou CAAT-box que é utilizado na classificação da região Core Promoter.

Ademais, o processo de predição realizado pelo TSSFinder não é limitado pela configuração da sequência de DNA como é observado nas outras duas ferramentas. Tanto para a ferramenta TIPR quanto para a ferramenta TSSPlant, a sequência de DNA precisa ser configurada para obtenção de melhores resultados de predição. Em geral, essa delimitação marca o posicionamento do TSS ou simplesmente limita a largura de procura do TSS. A utilização deste tipo de configuração pode limitar a predição ab initio do TSS para outros organismos que não apresentam nenhum conhecimento prévio sobre a localização do TSS. Por este motivo que o TSSFinder utiliza o sinal de ATG para ancorar o início do sequência de DNA, uma vez que este sinal é de comum conhecimento ou de fácil obtenção para diferentes organismos. Assim o modelo TSSFinder é capaz de realizar tanto a predição do TSS como rotulação da sequência de DNA upstream ao sinal de ATG sem nenhum conhecimento a priori da localização do TSS na sequência de DNA. Portanto, essa característica permite maior grau de generalização do TSSFinder e por conseguinte melhores resultados de predição do que as duas outras ferramentas analisadas.

A capacidade de re-treinamento do TSSFinder pelo usuário final é o grande diferencial do nosso modelo em relação a todas ferramentas de predição do sinal de TSS já descritas até hoje. A principal justificativa para o desenvolvimento desta habilidade está relacionado com o constante desenvolvimento da tecnologia de sequenciamento de DNA e a crescente expansão do conjunto de dados associados a identificação in vivo ou in vitro do sinal de TSS [Dreos et al., 2016]. Para acompanhar essa tendência e manter a longevidade da ferramenta TSSFinder nós habilitamos o re-treinamento da ferramenta para o usuário final. Além disso, nós avaliamos a habilidade do re-treinamento da ferramenta em diferentes grupos de sequências fl-cDNA com o número de total sequências variável. Os nossos resultados demonstraram a viabilidade dessa característica para diferentes organismos. Além disso, a ferramenta TSS- 
Finder foi capaz de executar a tarefa de predição do sinal de TSS independente do tamanho do conjunto de treinamento.

Além disso, o TSSFinder apresenta todos os resultados de predição no formato bed. Com este formato, a manipulação dos resultados é mais direta e de fácil incorporação nos arquivos de anotação gff e $g t f$. Esse tipo de apresentação dos resultados pode ser considerada mais uma característica diferencial da ferramenta TSSFinder em relação ao TSSPlant e TIPR. Nestas duas ferramentas os resultados não apresentam relação direta com os arquivos de anotação e por isso a verificação dos resultados e a incorporação dos mesmos nos arquivos de anotação genômico não é uma tarefa trivial. 


\section{Capítulo 6}

\section{Conclusão}

Neste estudo foi possível caracterizar a região regulatória de três genes importantes para cana-de-açúcar: $S c d r 1$ - tolerância a estresse abiótico; $S c S u S y$ - metabolismo de açúcar e $S c P A L$ - teor de lignina. O fluxo de trabalho para análise da região Promotora foi realizada com sucesso nós três genes e por isso foi expandido para a análise de genes co-expressos.

Neste trabalho foi apresentado que a região Promotora de genes da mesma família podem apresentar região Promotora com classificação diferente (TATA-box/TATA-less) e essa diferença pode ser associada com o mecanismo de expressão destes genes. Além disso, possível rotular a região Promotora de todos os genes analisados através da identificação do sinal de TSS e da estimativa do tamanho região 5' UTR.

Neste trabalho, a caracterização da região Promotora não ficou limitada para uma única cópia dos genes analisados. Foi possível caracterizar e comparar a região Promotora de cada gene homo/homeólogo. Além disso foi integrado dados de transcriptoma para dar suporte às análises de identificação de TFBS assim como para a separação das sequências de DNA homeólogas a cada gene avaliado.

A identificação de genes expressos foi fundamental para caracterização da região Promotora. Com isso, este fluxo de trabalho pode ser realizado em paralelo com diferentes análises de dados de transcriptoma.

Neste trabalho nós apresentamos a ferramenta TSSFinder de predição ab initio de TSS. Essa ferramenta foi superior aos outros modelos descritos na literatura. Além disso, a ferramenta TSSFinder foi capaz de identificar o sinal de TSS em diferentes organismos e esta característica está relacionada com a habilidade da ferramenta de ser re-treinada com diferentes conjuntos de dados genômicos. 
84 CONCLUSÃO 


\section{Apêndice A}

\section{Material Suplementar}

\section{A.0.1 Material e Métodos}

Tabela A.1: Representação em HMM do problema da moeda desonesta

\begin{tabular}{llll}
\multicolumn{4}{l}{ Probabilidades de emissão e transição para HMM } \\
\hline emissão & cara & honesto & 0.5 \\
emissão & coroa & honesto & 0.5 \\
Transição & desonesto & honesto & 0.05 \\
emissão & cara & desonesto & 0.3 \\
emissão & coroa & honesto & 0.7 \\
Transição & desonesto & desonesto & 0.9 \\
Transição & honesto & desonesto & 0.1 \\
Transição & honesto & honesto & 0.95 \\
\hline
\end{tabular}

Tabela A.2: Representação em LCCRF do problema da moeda desonesta

\begin{tabular}{llllll}
\multicolumn{6}{l}{ Probabilidade de cada features no modelo LCCRF } \\
\hline f1 $($ yI, xI $)$ & 0.5 & xI & cara & yI & honesto \\
f2(yI, xI & 0.5 & xI & coroa & yI & honesto \\
f3(yI, yI-1) & 0.05 & yI & desonesto & yI-1 & honesto \\
f4(yI, xI $)$ & 0.3 & xI & cara & yI & desonesto \\
f5(yI, xI $)$ & 0.7 & xI & coroa & yI & desonesto \\
f6(yI, yI-1) & 0.9 & yI & desonesto & yI-1 & desonesto \\
f7(yI, yI-1) & 0.1 & yI & honesto & yI-1 & desonesto \\
f8(yI, yI-1) & 0.95 & yI & honesto & yI-1 & honesto \\
\hline
\end{tabular}

\section{A.0.2 RNA-Seq de cana-de-açúcar suplementar}

A.0.3 TSSFinder: desempenho em diferentes organismos superiores 


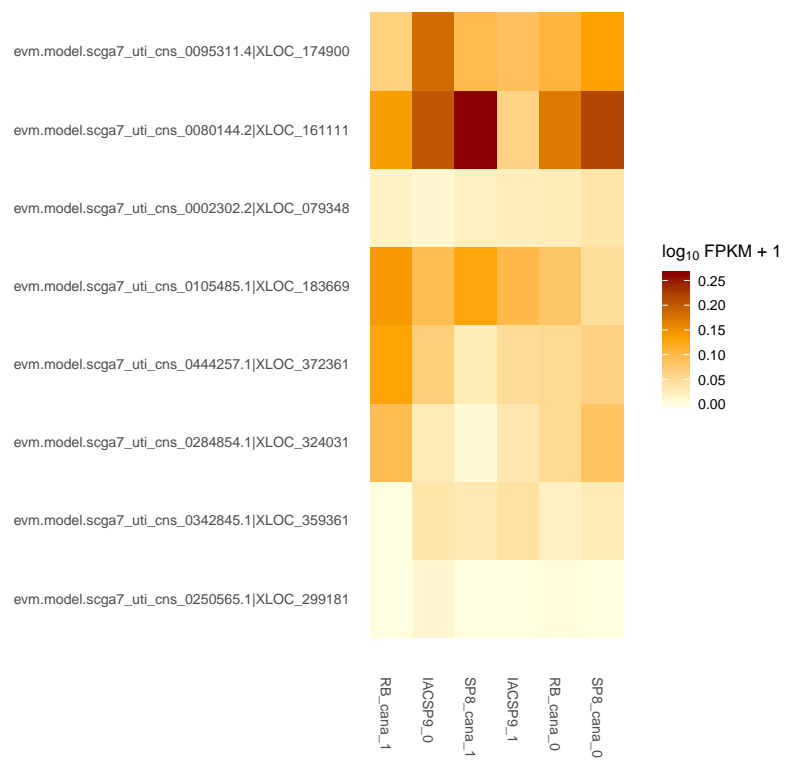

Figura A.1: Expressão da família gênica ScSuSy1 no transcriptoma de cana-de-açúcar. Expressão gênica de sequências homo/homeólogas da família de genes $S c$ SuSy1 no transcriptoma de cana-de-açúcar [Cardoso-Silva et al., 2014]. Linhas: Identificador dos genes no Genescpace de cana-de-açúcar SP80-3280. Colunas: Amostras avaliadas.

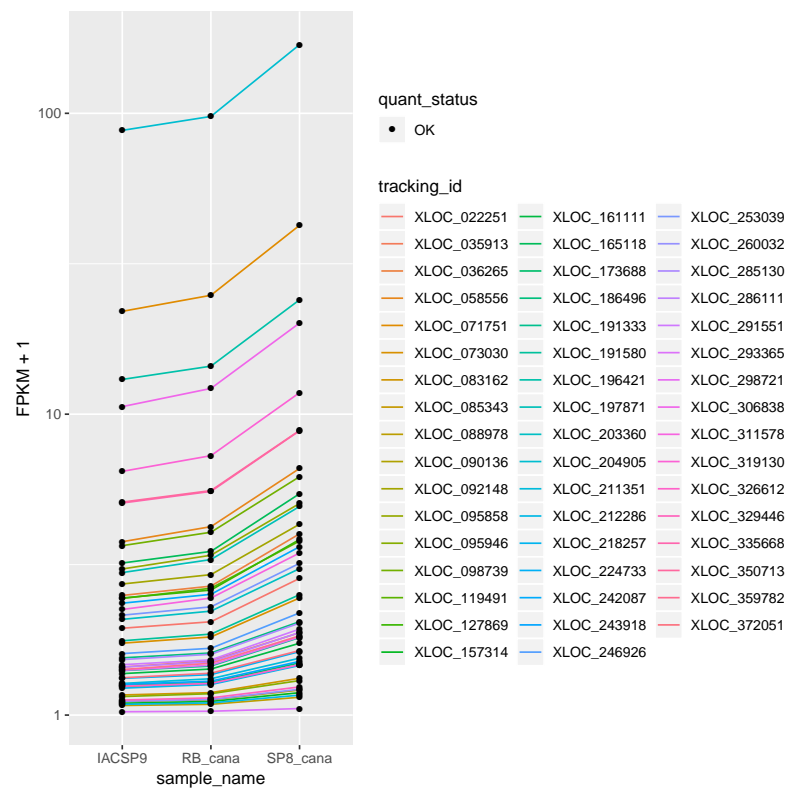

Figura A.2: Genes co-expressos com gene ScSuSy1 no transcriptoma de cana-de-açúcar. Dados do transcriptoma de cana-de-acúcar de [Cardoso-Silva et al., 2014]. Apresentação de 49 genes com expressão similar ao gene ScSuSy1 (80144.2 | XLOC_161111) Linhas: Identificador dos genes no Genescpace de cana-deaçúcar SP80-3280. Colunas: Amostras avaliadas. 


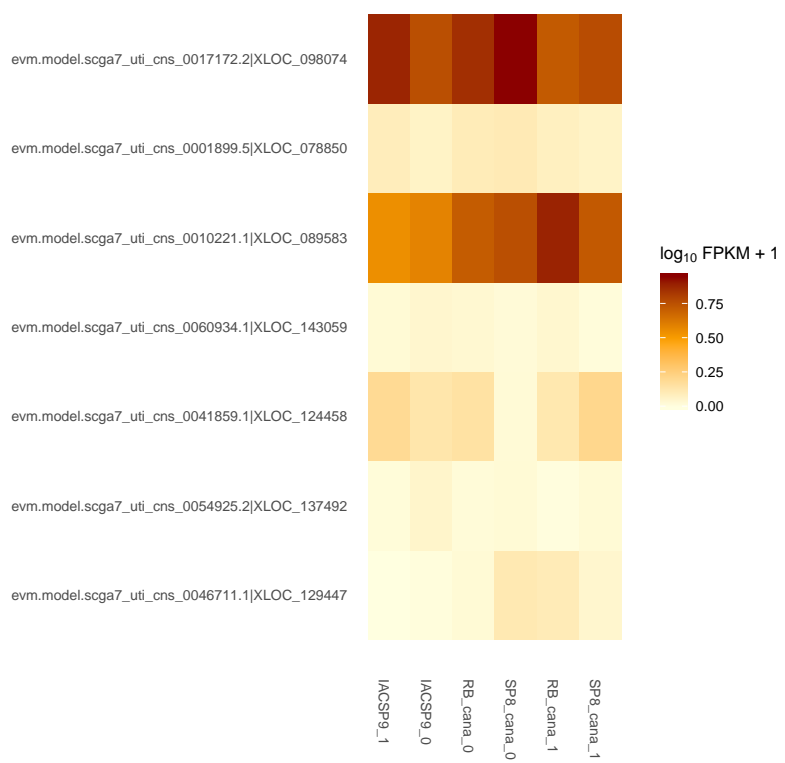

Figura A.3: Expressão da família gênica ScSuSy2 no transcriptoma de cana-de-açúcar. Expressão gênica de sequências homo/homeólogas da família de genes $S c$ SuSy2 no transcriptoma de cana-de-açúcar [Cardoso-Silva et al., 2014]. Linhas: Identificador dos genes no Genescpace de cana-de-açúcar SP80-3280. Colunas: Amostras avaliadas.

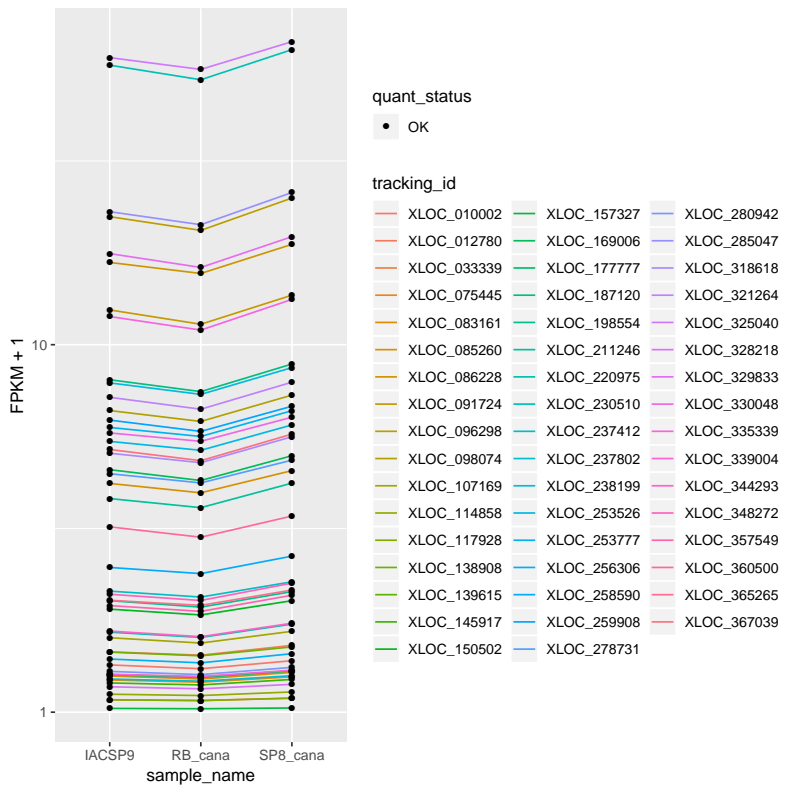

Figura A.4: Genes co-expressos com gene ScSuSy2 no transcriptoma de cana-de-açúcar. Dados do transcriptoma de cana-de-açúcar de [Cardoso-Silva et al., 2014]. Apresentação de 49 genes com expressão similar ao gene ScSuSy2 (17172.2 | XLOC_098074) Linhas: Identificador dos genes no Genescpace de cana-deaçúcar SP80-3280. Colunas: Amostras avaliadas. 


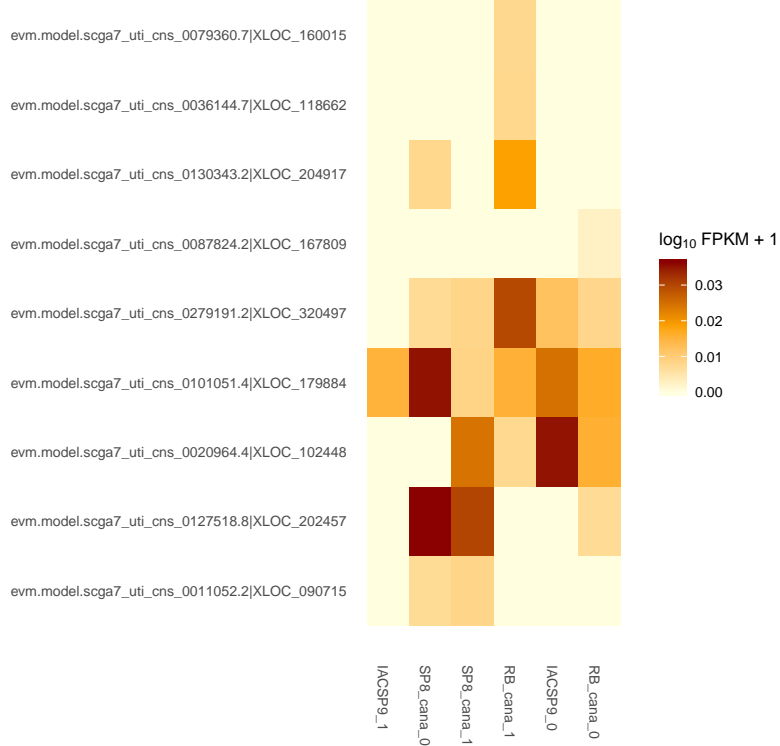

Figura A.5: Expressão da família gênica ScSuSy3 no transcriptoma de cana-de-açúcar Expressão gênica de sequências homo/homeólogas da família de genes $S c$ SuSy3 no transcriptoma de cana-de-açúcar [Cardoso-Silva et al., 2014]. Linhas: Identificador dos genes no Genescpace de cana-de-açúcar SP80-3280. Colunas: Amostras avaliadas.

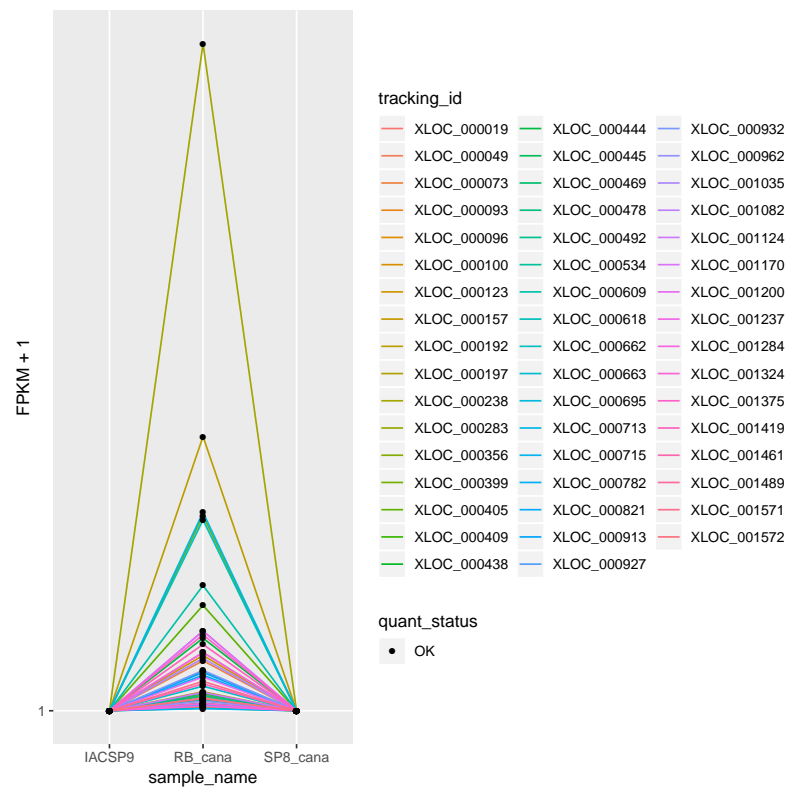

Figura A.6: Genes co-expressos com gene ScSuSy3 no transcriptoma de cana-de-açúcar. Dados do transcriptoma de cana-de-acúcar de [Cardoso-Silva et al., 2014]. Apresentação de 49 genes com expressão similar ao gene ScSuSy3 (87824.2 | XLOC_167809) Linhas: Identificador dos genes no Genescpace de cana-deaçúcar SP80-3280. Colunas: Amostras avaliadas. 


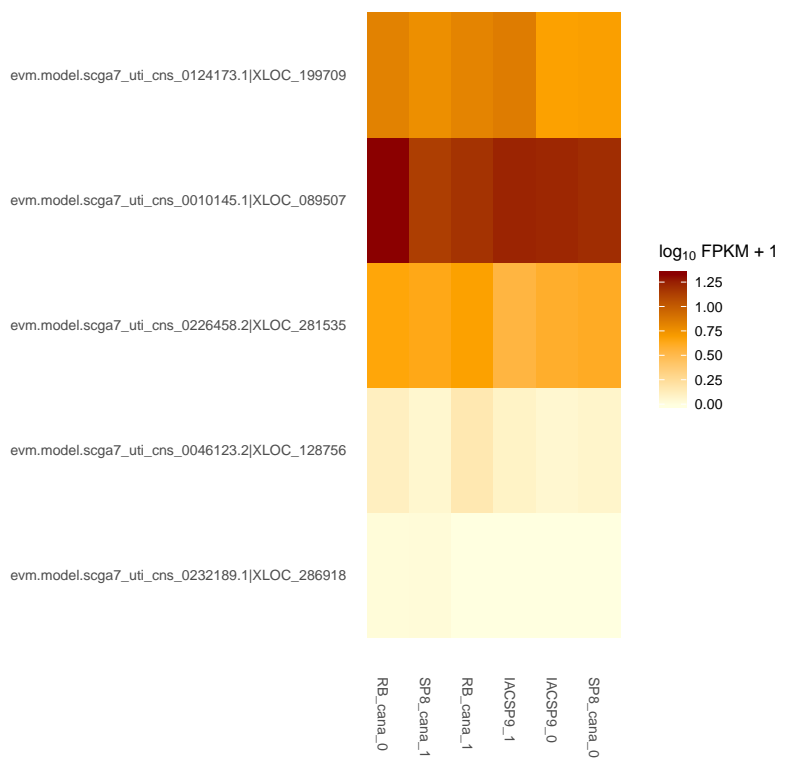

Figura A.7: Expressão da família gênica ScSuSy4 no transcriptoma de cana-de-açúcar. Expressão gênica de sequências homo/homeólogas da família de genes $S c$ SuSy4 no transcriptoma de cana-de-açúcar [Cardoso-Silva et al., 2014]. Linhas: Identificador dos genes no Genescpace de cana-de-açúcar SP80-3280. Colunas: Amostras avaliadas.

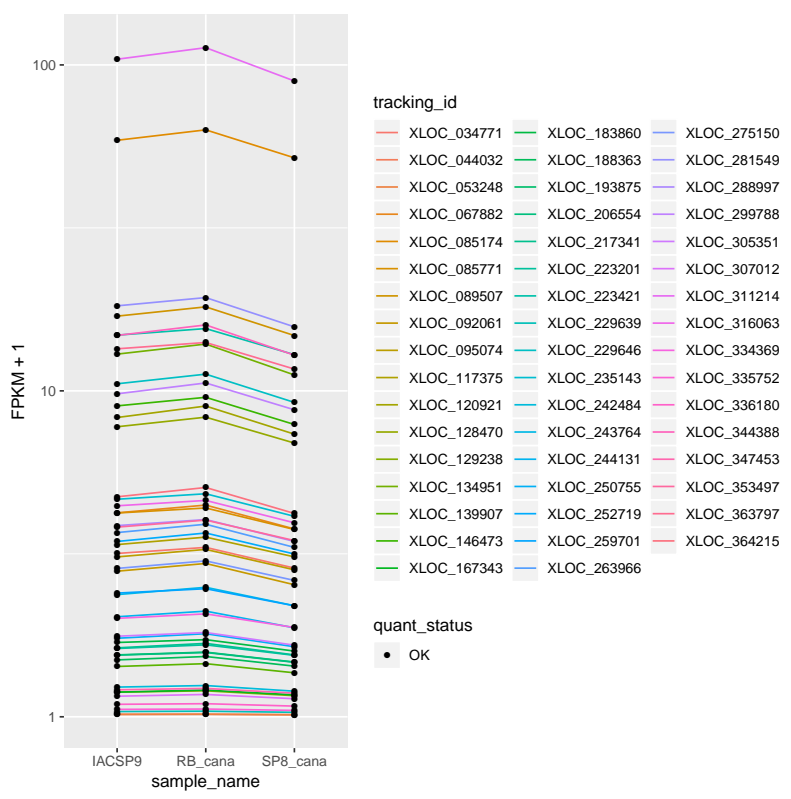

Figura A.8: Genes co-expressos com gene ScSuSy4 no transcriptoma de cana-de-açúcar. Dados do transcriptoma de cana-de-açúcar de [Cardoso-Silva et al., 2014]. Apresentação de 49 genes com expressão similar ao gene ScSuSy4 (10145.1 | XLOC_089507) Linhas: Identificador dos genes no Genescpace de cana-deaçúcar SP80-3280. Colunas: Amostras avaliadas. 


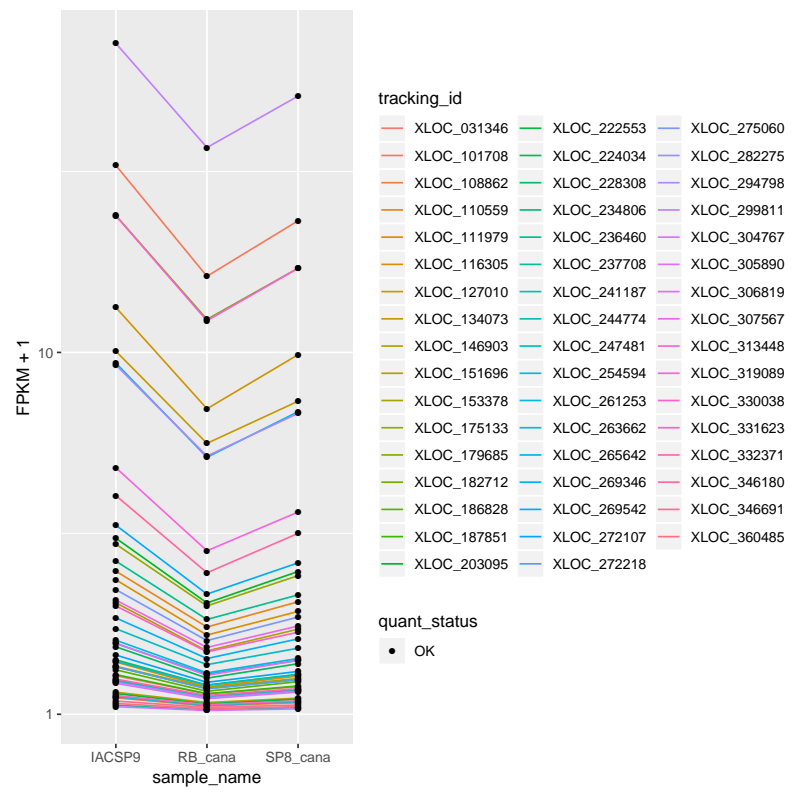

Figura A.9: Genes co-expressos com gene ScSuSy5 no transcriptoma de cana-de-açúcar. Dados do transcriptoma de cana-de-açúcar de [Cardoso-Silva et al., 2014]. Apresentação de 49 genes com expressão similar ao gene ScSuSy5 (256513.2 | XLOC_304767) Linhas: Identificador dos genes no Genescpace de cana-deaçúcar SP80-3280. Colunas: Amostras avaliadas.

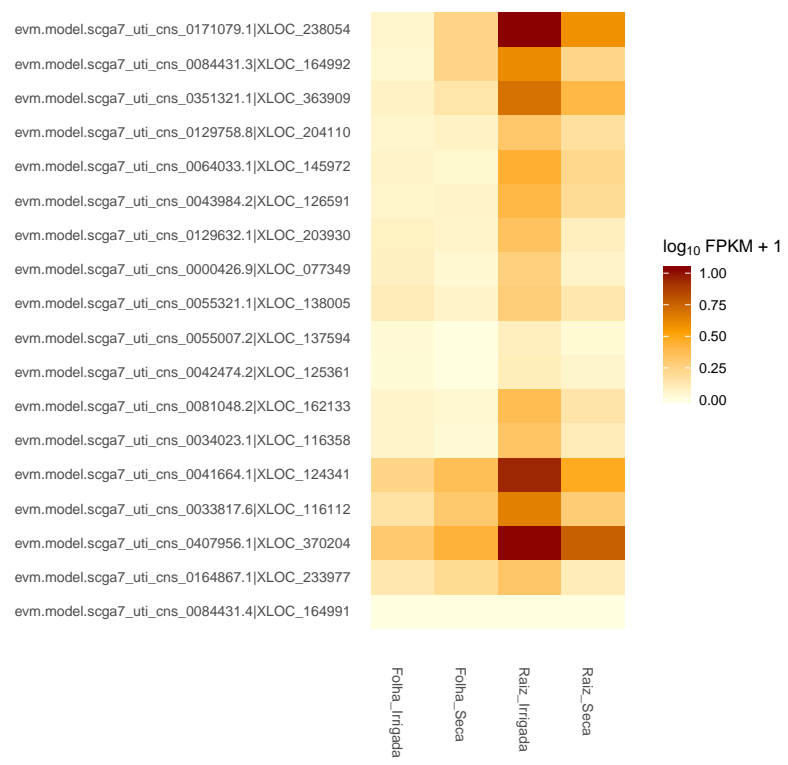

Figura A.10: Expressão da família gênica ScPAL1 no transcriptoma de cana-de-açúcar. Expressão gênica de sequências homo/homeólogas da família de genes $S c$ PAL1 no transcriptoma de cana-de-açúcar [Cardoso-Silva et al., 2014]. Linhas: Identificador dos genes no Genescpace de cana-de-açúcar SP80-3280. Colunas: Amostras avaliadas. 


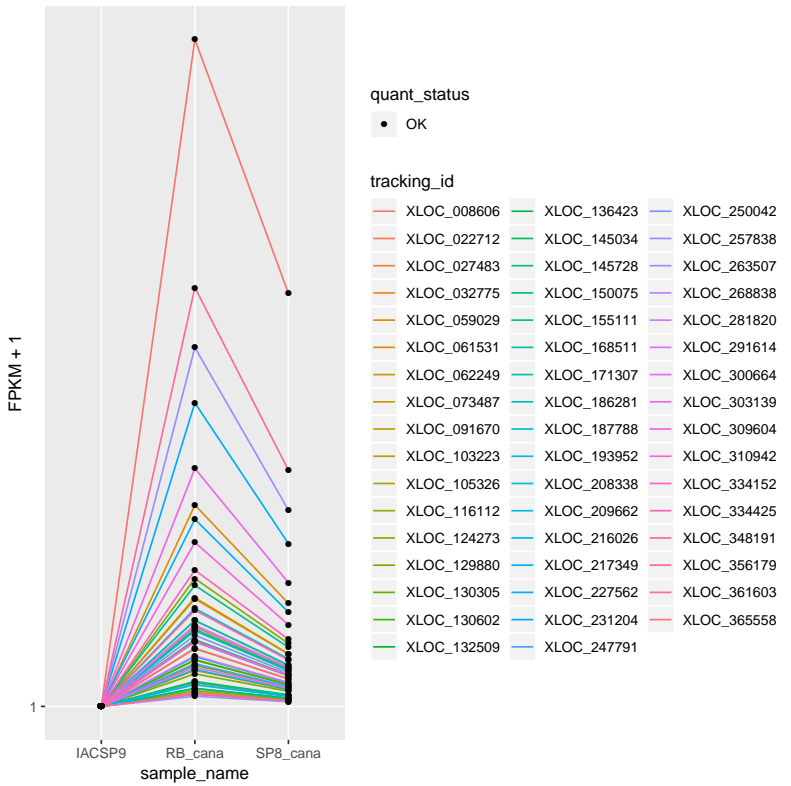

Figura A.11: Genes co-expressos com gene ScPAL1 no transcriptoma de cana-de-açúcar. Dados do transcriptoma de cana-de-acúcar de [Cardoso-Silva et al., 2014]. Apresentação de 49 genes com expressão similar ao gene ScPAL1 (33817.6 | XLOC_116112) Linhas: Identificador dos genes no Genescpace de cana-deaçúcar SP80-3280. Colunas: Amostras avaliadas.

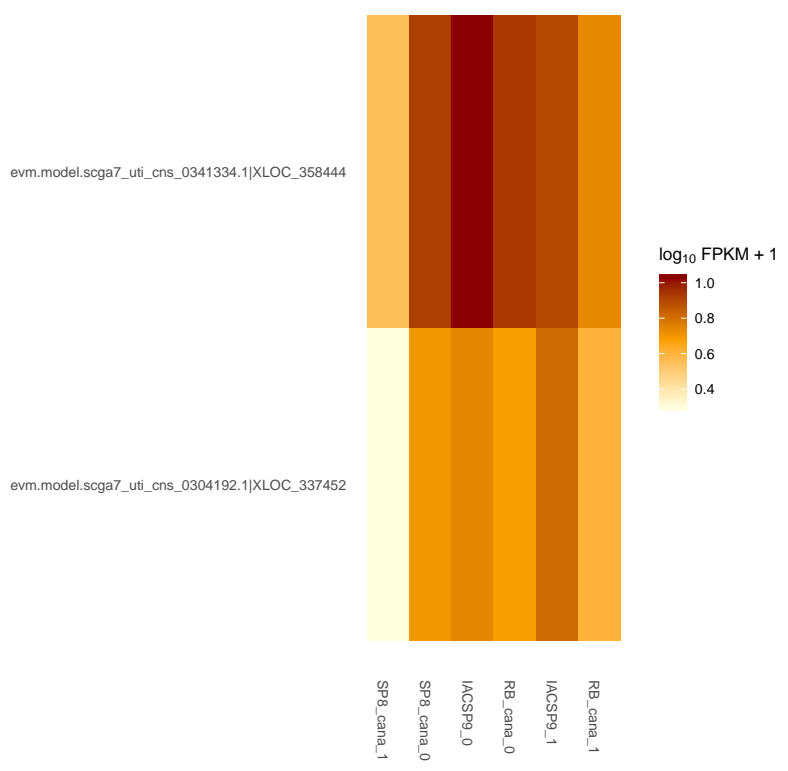

Figura A.12: Expressão da família gênica ScPAL2 no transcriptoma de cana-de-açúcar. Expressão gênica de sequências homo/homeólogas da família de genes $S c$ PAL2 no transcriptoma de cana-de-açúcar [Cardoso-Silva et al., 2014]. Linhas: Identificador dos genes no Genescpace de cana-de-açúcar SP80-3280. Colunas: Amostras avaliadas. 


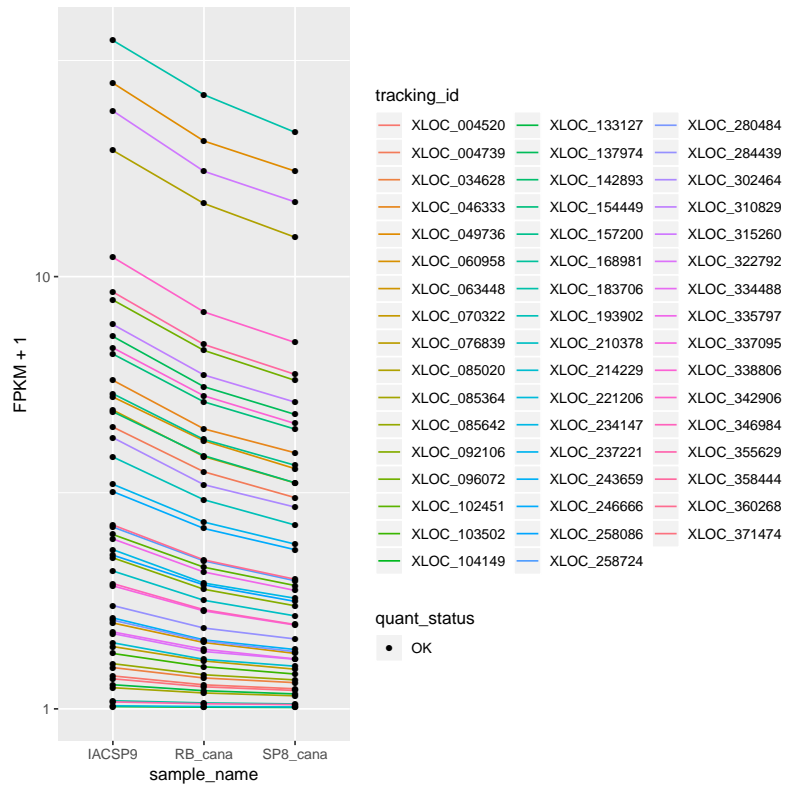

Figura A.13: Genes co-expressos com gene ScPAL2 no transcriptoma de cana-de-açúcar. Dados do transcriptoma de cana-de-acúcar de [Cardoso-Silva et al., 2014]. Apresentação de 49 genes com expressão similar ao gene ScPAL2 (341334.1 | XLOC_358444) Linhas: Identificador dos genes no Genescpace de cana-deaçúcar SP80-3280. Colunas: Amostras avaliadas.

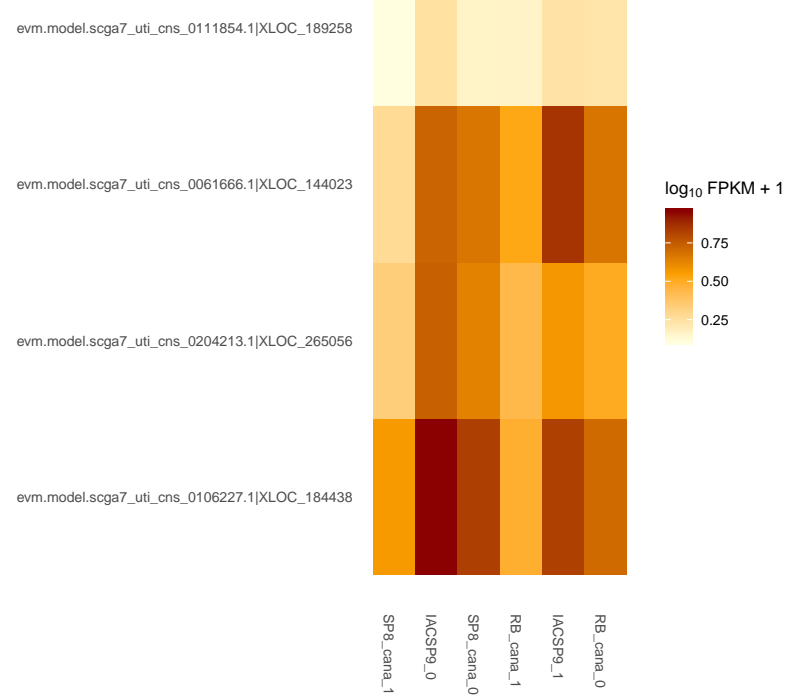

Figura A.14: Expressão da família gênica ScPAL3 no transcriptoma de cana-de-açúcar. Expressão gênica de sequências homo/homeólogas da família de genes $\mathrm{Sc}$ PAL3 no transcriptoma de cana-de-açúcar [Cardoso-Silva et al., 2014]. Linhas: Identificador dos genes no Genescpace de cana-de-açúcar SP80-3280. Colunas: Amostras avaliadas. 


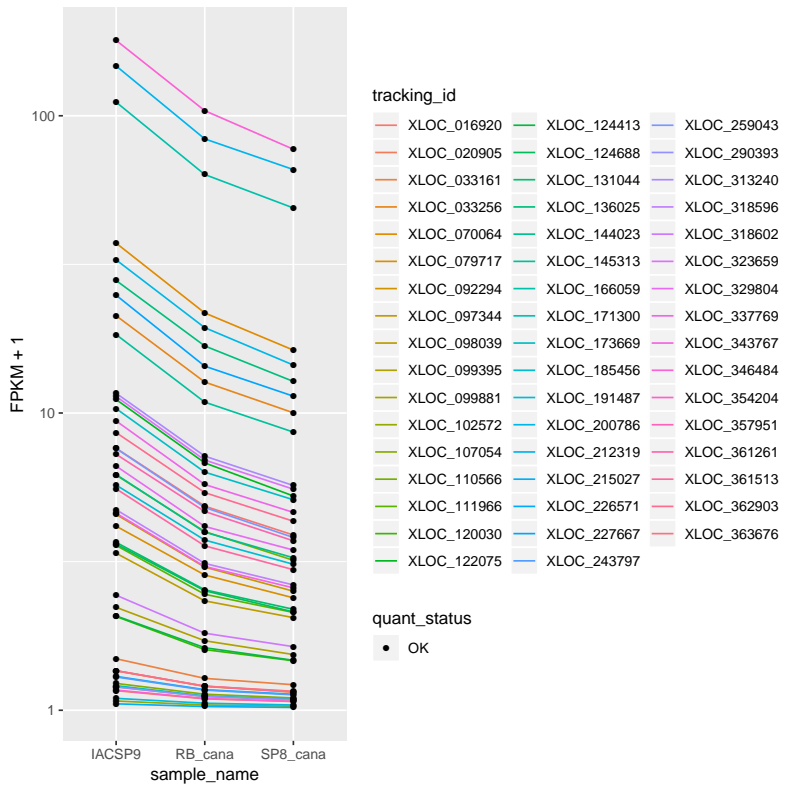

Figura A.15: Genes co-expressos com gene ScPAL3 no transcriptoma de cana-de-açúcar. Dados do transcriptoma de cana-de-acúcar de [Cardoso-Silva et al., 2014]. Apresentação de 49 genes com expressão similar ao gene ScPAL3 (61666.1 | XLOC_144023) Linhas: Identificador dos genes no Genescpace de cana-deaçúcar SP80-3280. Colunas: Amostras avaliadas.

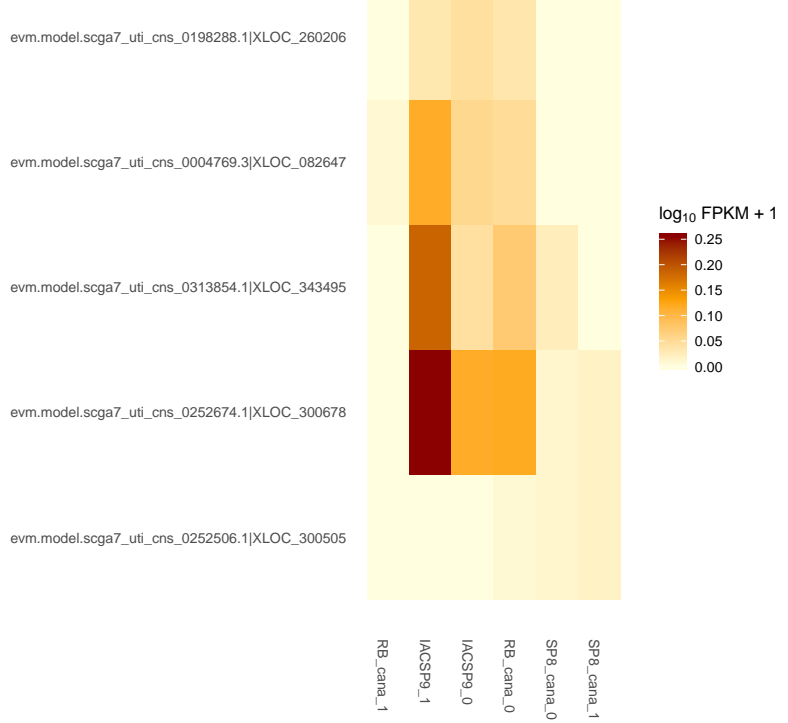

Figura A.16: Expressão da família gênica ScPAL4 no transcriptoma de cana-de-açúcar. Expressão gênica de sequências homo/homeólogas da família de genes $S c$ PAL4 no transcriptoma de cana-de-açúcar [Cardoso-Silva et al., 2014]. Linhas: Identificador dos genes no Genescpace de cana-de-açúcar SP80-3280. Colunas: Amostras avaliadas. 


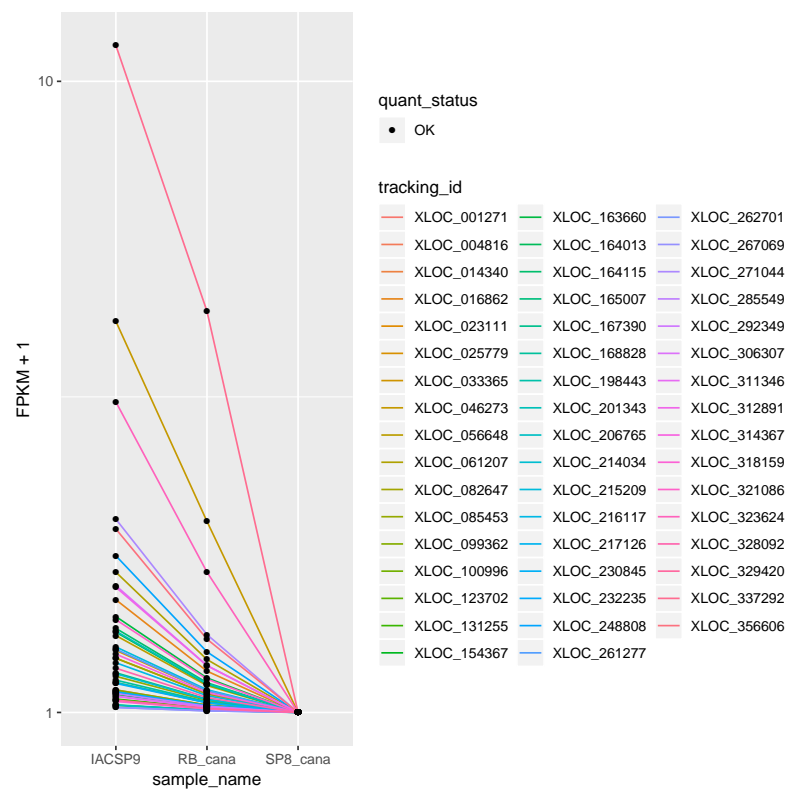

Figura A.17: Genes co-expressos com gene ScPAL4 no transcriptoma de cana-de-açúcar. Dados do transcriptoma de cana-de-acúcar de [Cardoso-Silva et al., 2014]. Apresentação de 49 genes com expressão similar ao gene ScPAL4 (4769.3 | XLOC_082647) Linhas: Identificador dos genes no Genescpace de cana-deaçúcar SP80-3280. Colunas: Amostras avaliadas.

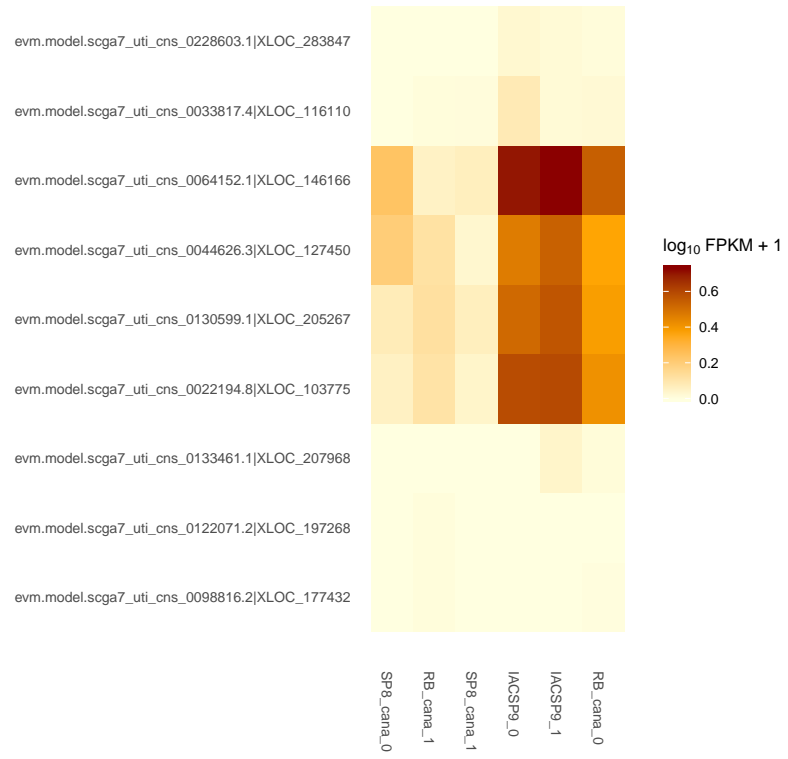

Figura A.18: Expressão da família gênica ScPAL5 no transcriptoma de cana-de-açúcar. Expressão gênica de sequências homo/homeólogas da família de genes $S c$ PAL5 no transcriptoma de cana-de-açúcar [Cardoso-Silva et al., 2014]. Linhas: Identificador dos genes no Genescpace de cana-de-açúcar SP80-3280. Colunas: Amostras avaliadas. 


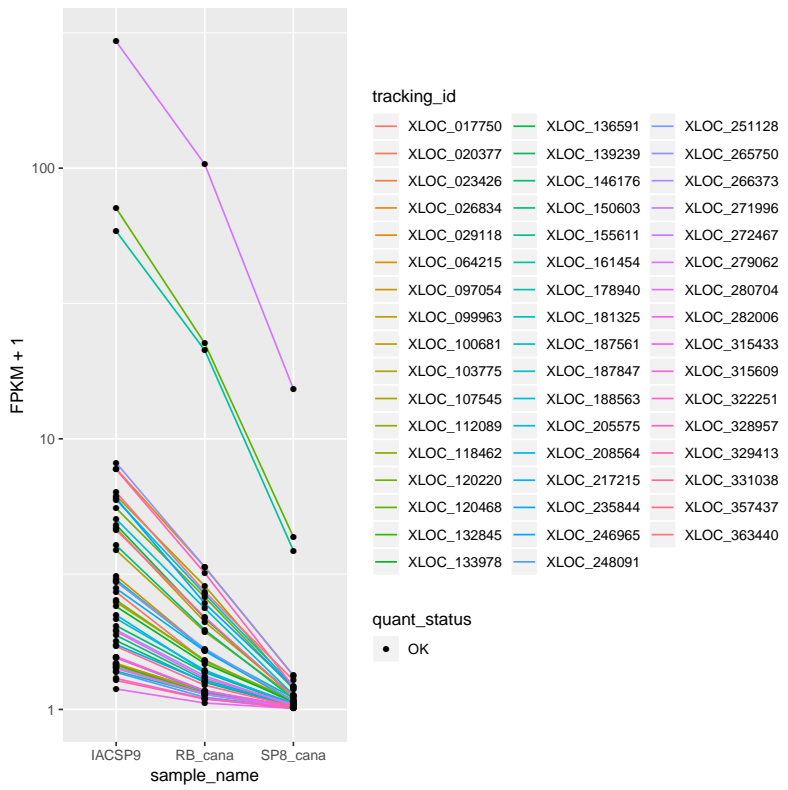

Figura A.19: Genes co-expressos com gene ScPAL5 no transcriptoma de cana-de-açúcar. Dados do transcriptoma de cana-de-acúcar de [Cardoso-Silva et al., 2014]. Apresentação de 49 genes com expressão similar ao gene ScPAL5 (22194.8 | XLOC_103775) Linhas: Identificador dos genes no Genescpace de cana-deaçúcar SP80-3280. Colunas: Amostras avaliadas.

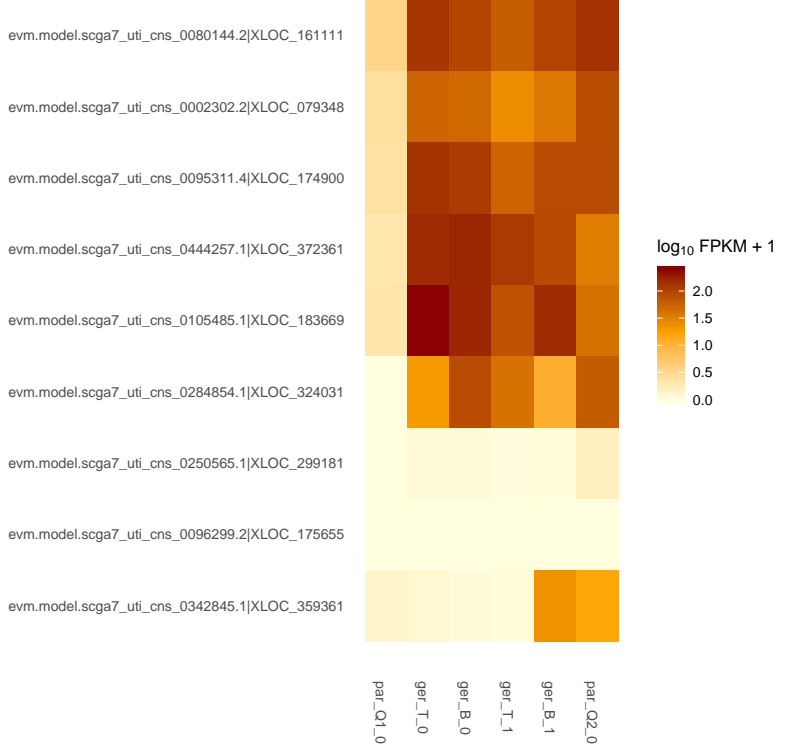

Figura A.20: Expressão da família gênica ScSuSy1 no transcriptoma de cana-de-açúcar. Expressão gênica de sequências homo/homeólogas da família de genes $\mathrm{Sc}$ SuSy1 no transcriptoma de cana-de-açúcar minlin. Linhas: Identificador dos genes no Genescpace de cana-de-açúcar SP80-3280. Colunas: Amostras avaliadas. 


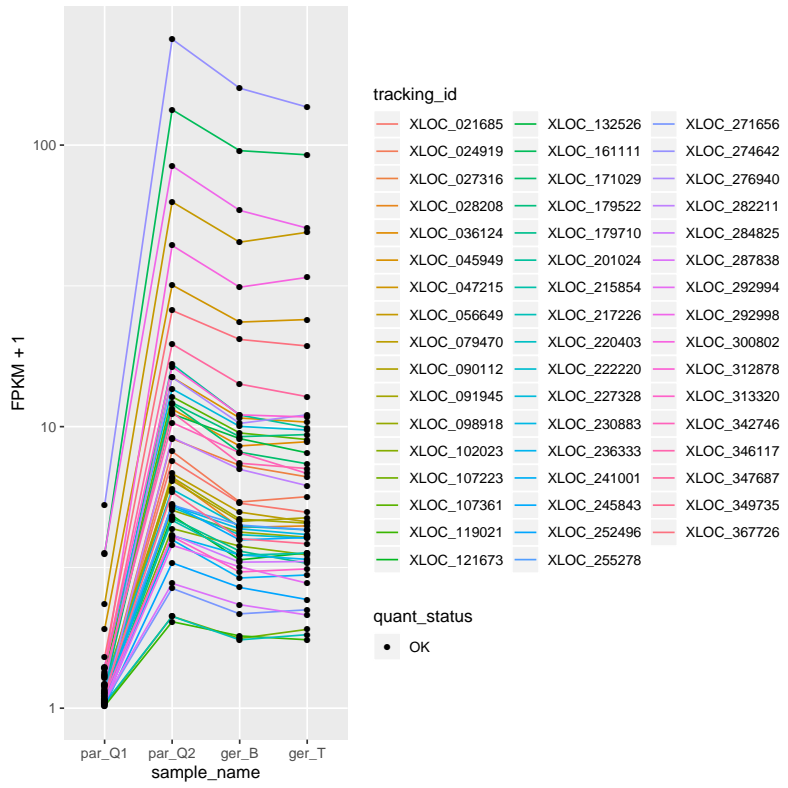

Figura A.21: Genes co-expressos com gene ScSuSy1 no transcriptoma de cana-de-açúcar. Dados do transcriptoma de cana-de-acúcar de minlin. Apresentação de 49 genes com expressão similar ao gene ScSuSy1 (80144.2 | XLOC_161111) Linhas: Identificador dos genes no Genescpace de cana-de-açúcar SP80-3280. Colunas: Amostras avaliadas.

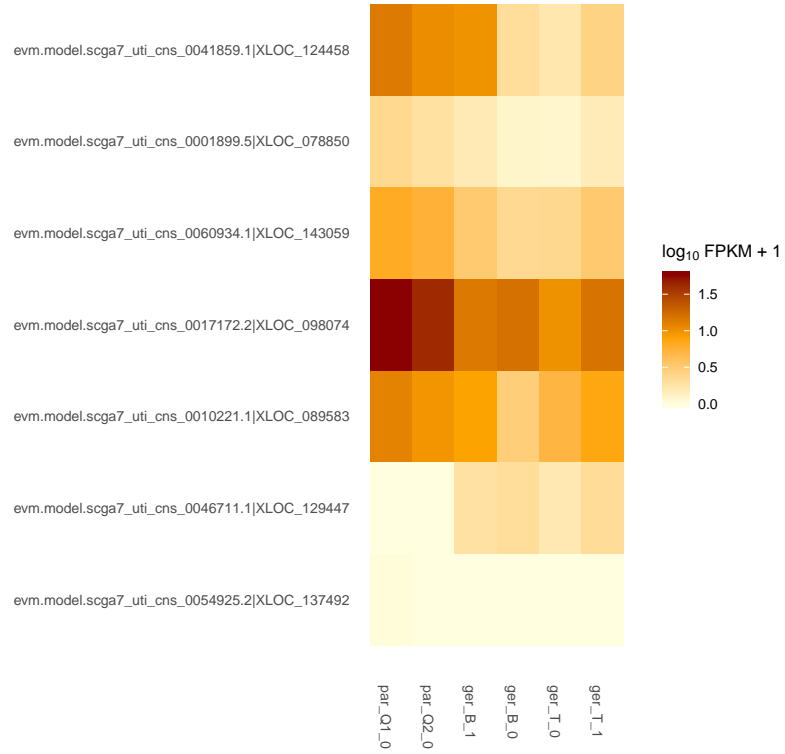

Figura A.22: Expressão da família gênica ScSuSy2 no transcriptoma de cana-de-açúcar. Expressão gênica de sequências homo/homeólogas da família de genes $S c$ SuSy2 no transcriptoma de cana-de-açúcar minlin. Linhas: Identificador dos genes no Genescpace de cana-de-açúcar SP80-3280. Colunas: Amostras avaliadas. 


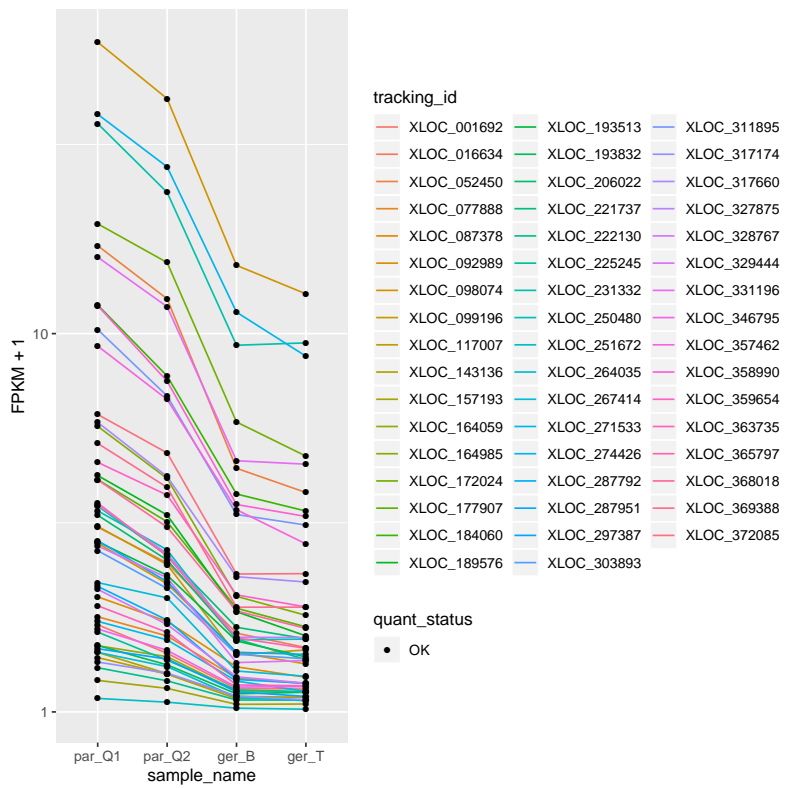

Figura A.23: Genes co-expressos com gene ScSuSy2 no transcriptoma de cana-de-açúcar. Dados do transcriptoma de cana-de-açúcar de minlin. Apresentação de 49 genes com expressão similar ao gene ScSuSy2 (17172.2 | XLOC_098074) Linhas: Identificador dos genes no Genescpace de cana-de-açúcar SP80-3280. Colunas: Amostras avaliadas.

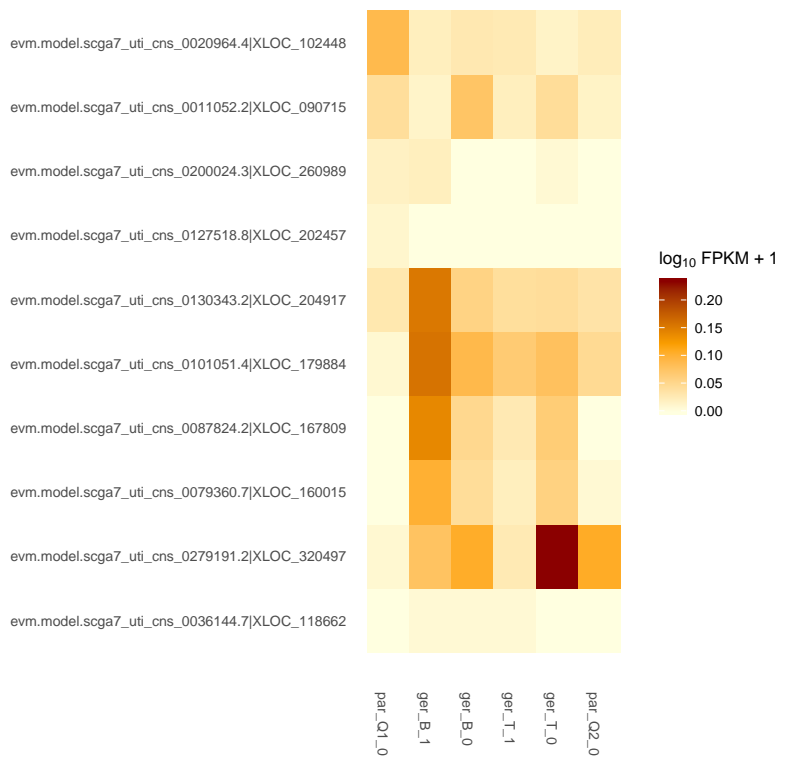

Figura A.24: Expressão da família gênica ScSuSy3 no transcriptoma de cana-de-açúcar Expressão gênica de sequências homo/homeólogas da família de genes $S c$ SuSy3 no transcriptoma de cana-de-açúcar minlin. Linhas: Identificador dos genes no Genescpace de cana-de-açúcar SP80-3280. Colunas: Amostras avaliadas. 


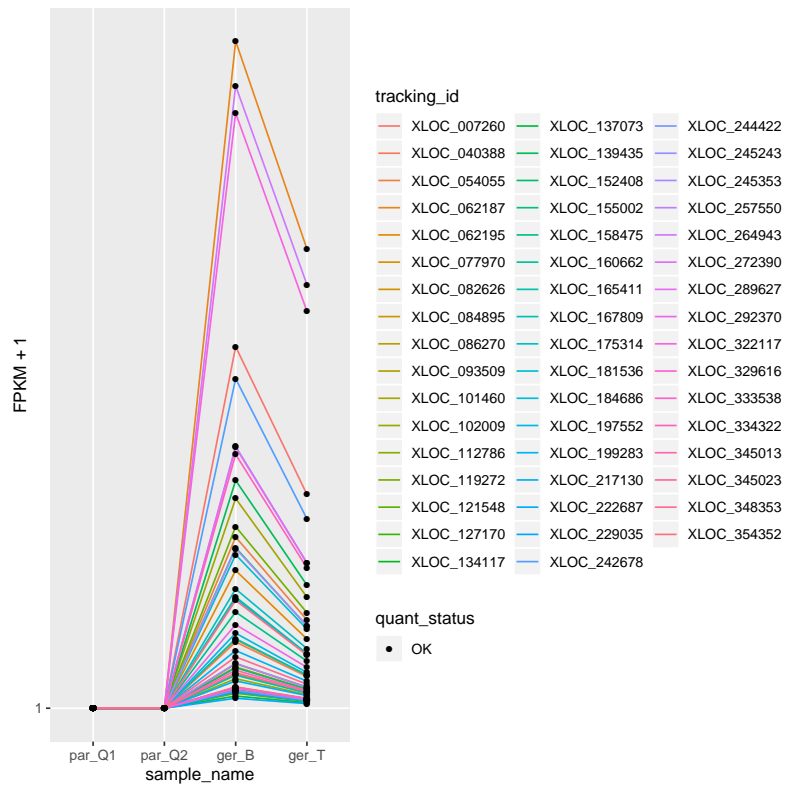

Figura A.25: Genes co-expressos com gene ScSuSy3 no transcriptoma de cana-de-açúcar. Dados do transcriptoma de cana-de-acúcar de minlin. Apresentação de 49 genes com expressão similar ao gene ScSuSy3 (87824.2 | XLOC_167809) Linhas: Identificador dos genes no Genescpace de cana-de-açúcar SP80-3280. Colunas: Amostras avaliadas.

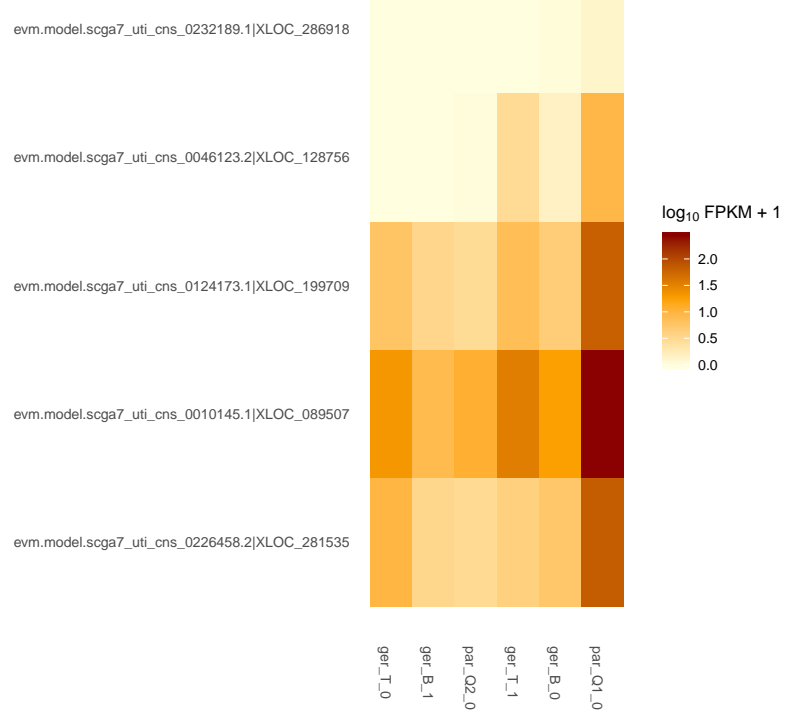

Figura A.26: Expressão da família gênica ScSuSy4 no transcriptoma de cana-de-açúcar. Expressão gênica de sequências homo/homeólogas da família de genes $S c$ SuSy4 no transcriptoma de cana-de-açúcar minlin. Linhas: Identificador dos genes no Genescpace de cana-de-açúcar SP80-3280. Colunas: Amostras avaliadas. 


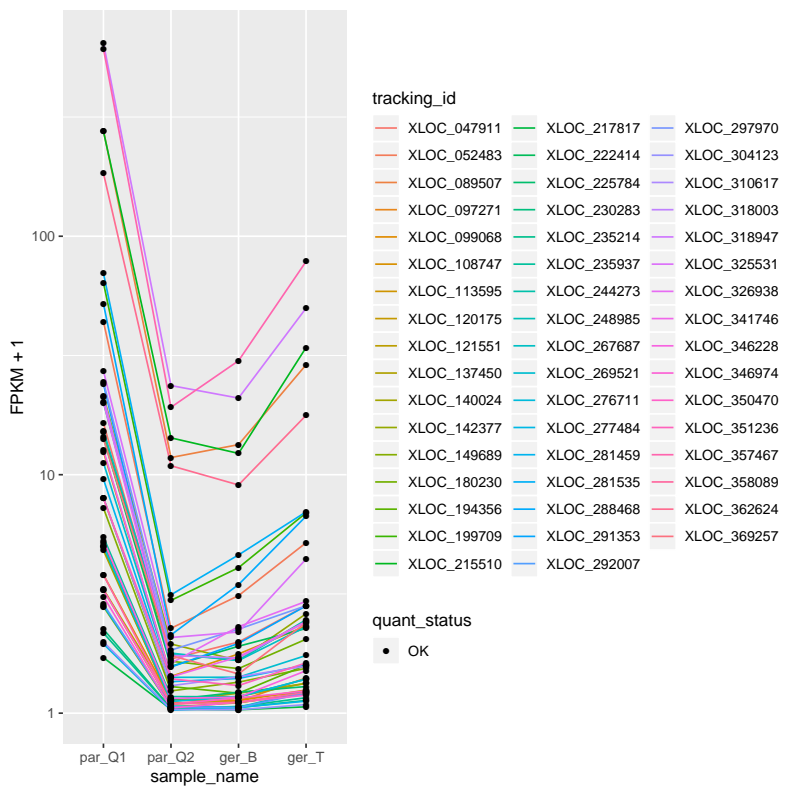

Figura A.27: Genes co-expressos com gene ScSuSy4 no transcriptoma de cana-de-açúcar. Dados do transcriptoma de cana-de-açúcar de minlin. Apresentação de 49 genes com expressão similar ao gene ScSuSy4 (10145.1 | XLOC_089507) Linhas: Identificador dos genes no Genescpace de cana-de-açúcar SP80-3280. Colunas: Amostras avaliadas.

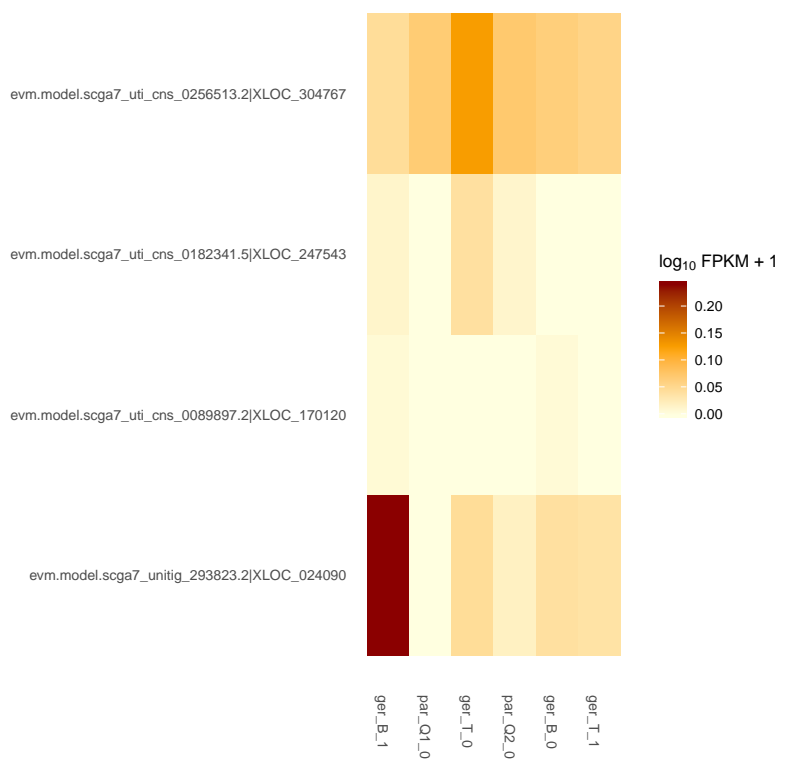

Figura A.28: Expressão da família gênica ScSuSy5 no transcriptoma de cana-de-açúcar. Expressão gênica de sequências homo/homeólogas da família de genes $S c$ SuSy5 no transcriptoma de cana-de-açúcar minlin. Linhas: Identificador dos genes no Genescpace de cana-de-açúcar SP80-3280. Colunas: Amostras avaliadas. 


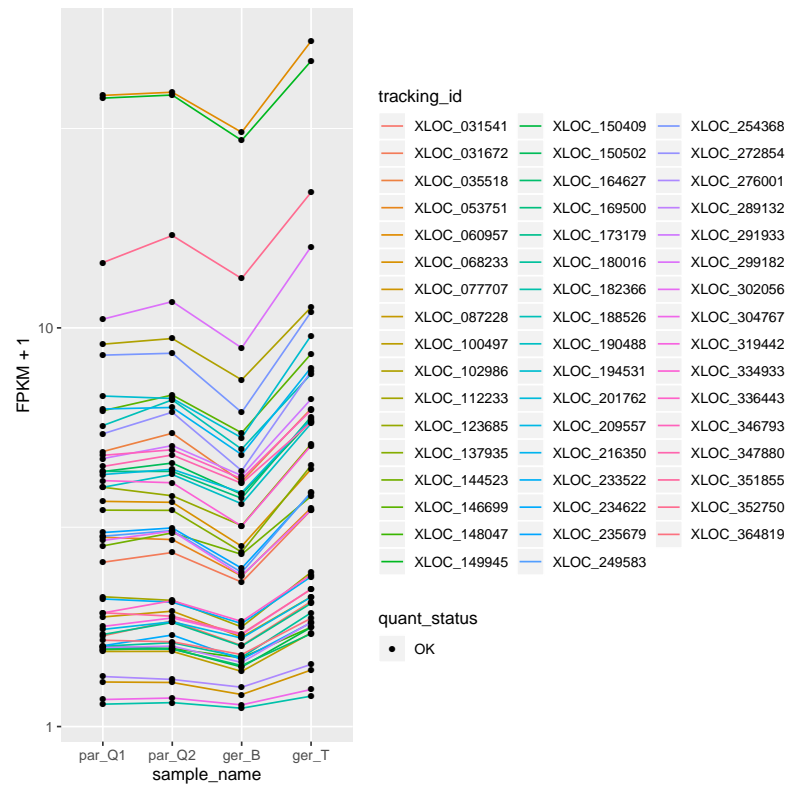

Figura A.29: Genes co-expressos com gene ScSuSy5 no transcriptoma de cana-de-açúcar. Dados do transcriptoma de cana-de-açúcar de [Li et al., 2016]. Apresentação de 49 genes com expressão similar ao gene ScSuSy5 (256513.2 | XLOC_304767) Linhas: Identificador dos genes no Genescpace de cana-de-açúcar SP80-3280. Colunas: Amostras avaliadas.
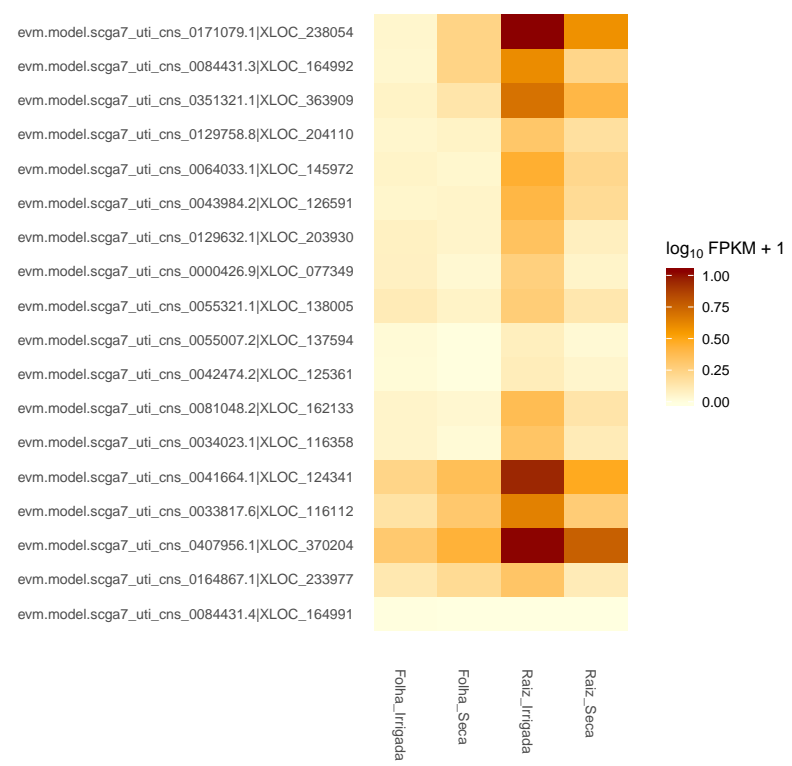

Figura A.30: Expressão da família gênica ScPAL1 no transcriptoma de cana-de-açúcar. Expressão gênica de sequências homo/homeólogas da família de genes $S c P A L 1$ no transcriptoma de cana-de-açúcar [Li et al., 2016]. Linhas: Identificador dos genes no Genescpace de cana-de-açúcar SP80-3280. Colunas: Amostras avaliadas. 


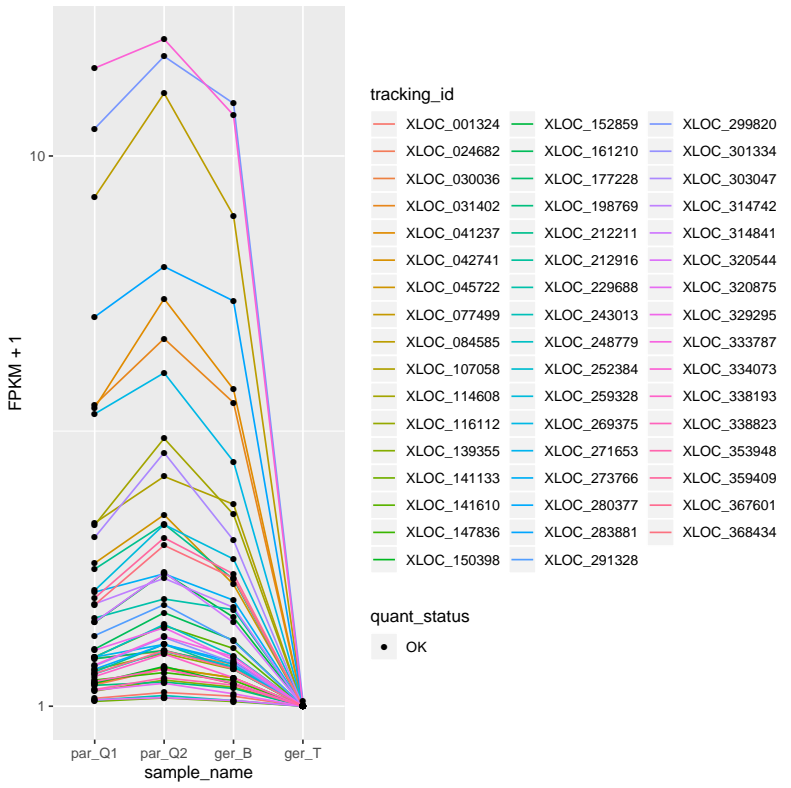

Figura A.31: Genes co-expressos com gene ScPAL1 no transcriptoma de cana-de-açúcar. Dados do transcriptoma de cana-de-acúcar de [Li et al., 2016]. Apresentação de 49 genes com expressão similar ao gene ScPAL1 (33817.6 | XLOC_116112) Linhas: Identificador dos genes no Genescpace de cana-de-açúcar SP80-3280. Colunas: Amostras avaliadas.

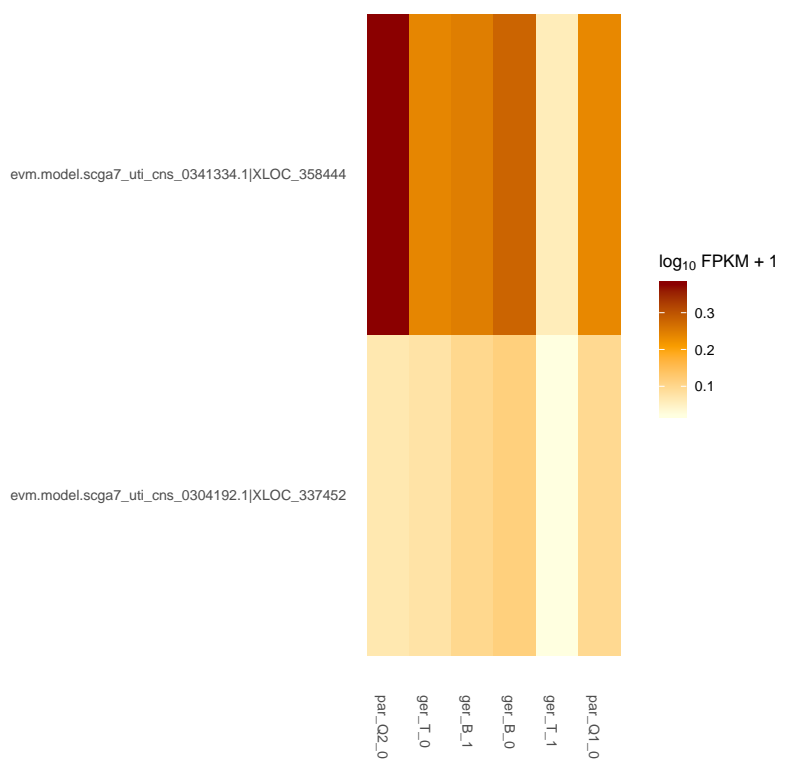

Figura A.32: Expressão da família gênica ScPAL2 no transcriptoma de cana-de-açúcar. Expressão gênica de sequências homo/homeólogas da família de genes ScPAL2 no transcriptoma de cana-de-açúcar [Li et al., 2016]. Linhas: Identificador dos genes no Genescpace de cana-de-açúcar SP80-3280. Colunas: Amostras avaliadas. 


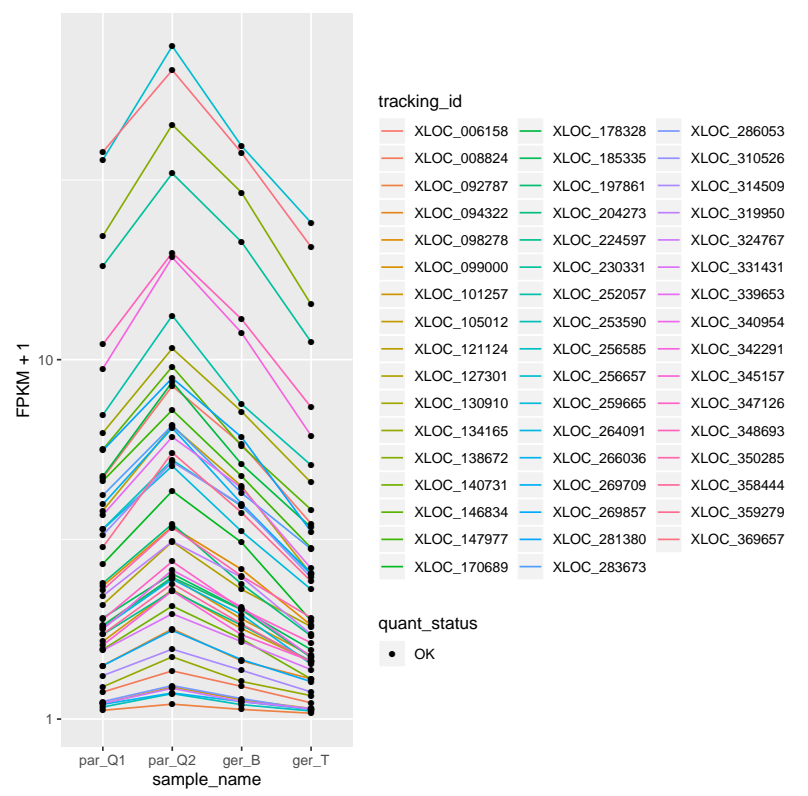

Figura A.33: Genes co-expressos com gene ScPAL2 no transcriptoma de cana-de-açúcar. Dados do transcriptoma de cana-de-acúcar de [Li et al., 2016]. Apresentação de 49 genes com expressão similar ao gene ScPAL2 (341334.1 | XLOC_358444) Linhas: Identificador dos genes no Genescpace de cana-de-açúcar SP80-3280. Colunas: Amostras avaliadas.

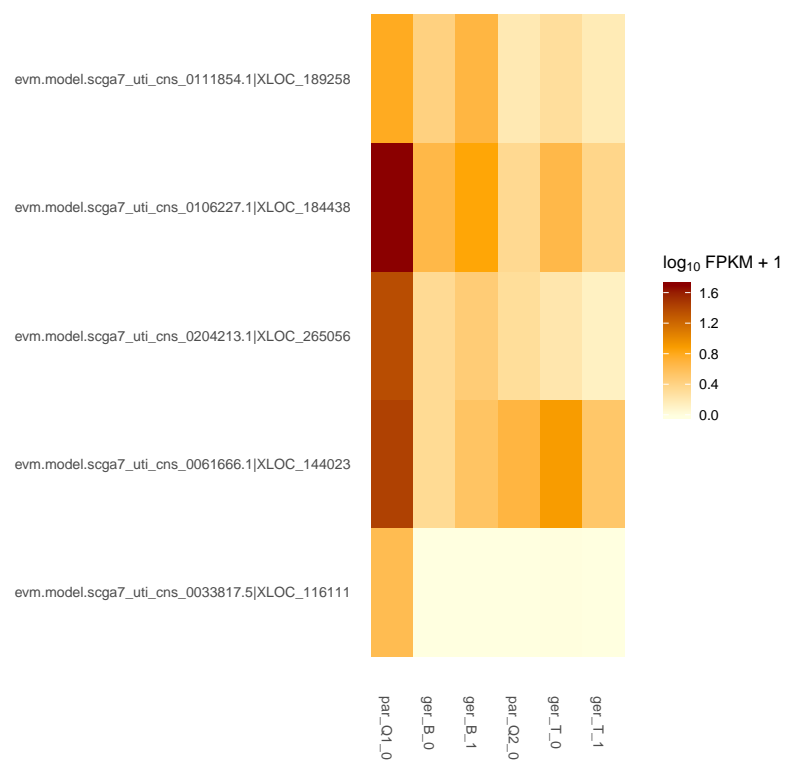

Figura A.34: Expressão da família gênica ScPAL3 no transcriptoma de cana-de-açúcar. Expressão gênica de sequências homo/homeólogas da família de genes $S c P A L 3$ no transcriptoma de cana-de-açúcar [Li et al., 2016]. Linhas: Identificador dos genes no Genescpace de cana-de-açúcar SP80-3280. Colunas: Amostras avaliadas. 


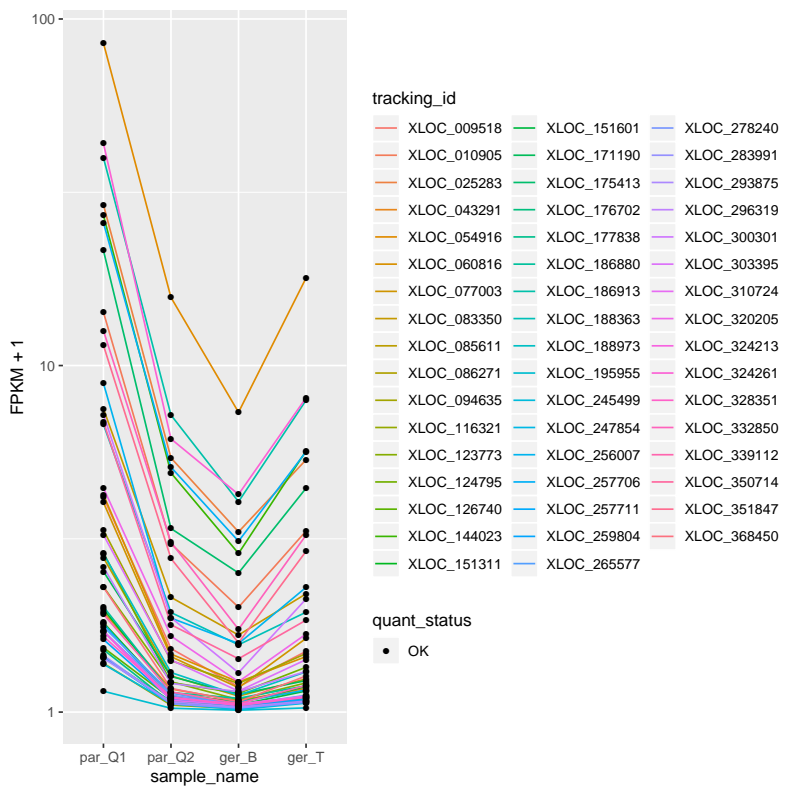

Figura A.35: Genes co-expressos com gene ScPAL3 no transcriptoma de cana-de-açúcar. Dados do transcriptoma de cana-de-acúcar de [Li et al., 2016]. Apresentação de 49 genes com expressão similar ao gene ScPAL3 (61666.1 | XLOC_144023) Linhas: Identificador dos genes no Genescpace de cana-de-açúcar SP80-3280. Colunas: Amostras avaliadas.

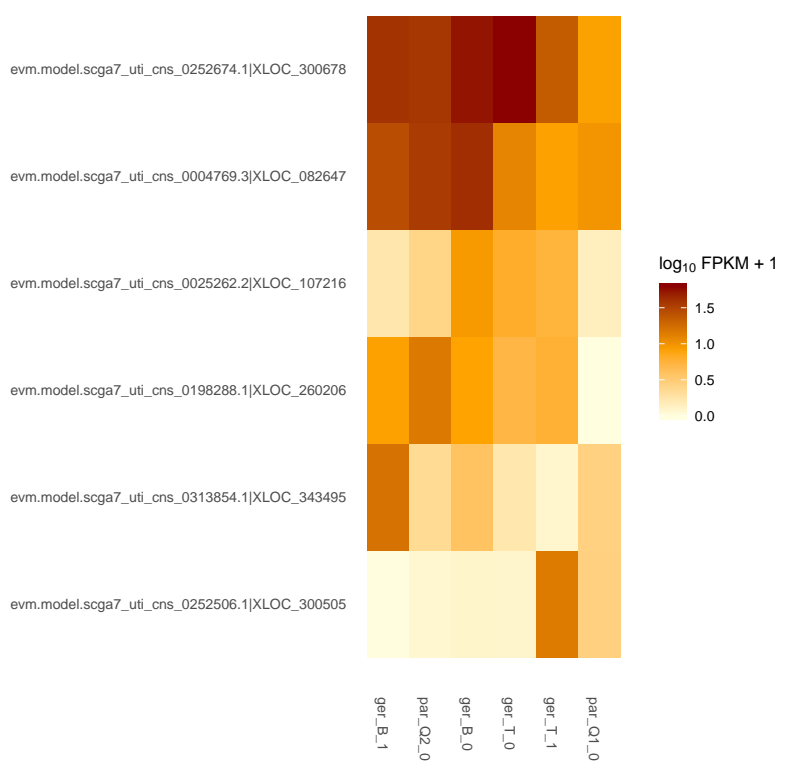

Figura A.36: Expressão da família gênica ScPAL4 no transcriptoma de cana-de-açúcar. Expressão gênica de sequências homo/homeólogas da família de genes ScPAL4 no transcriptoma de cana-de-açúcar [Li et al., 2016]. Linhas: Identificador dos genes no Genescpace de cana-de-açúcar SP80-3280. Colunas: Amostras avaliadas. 


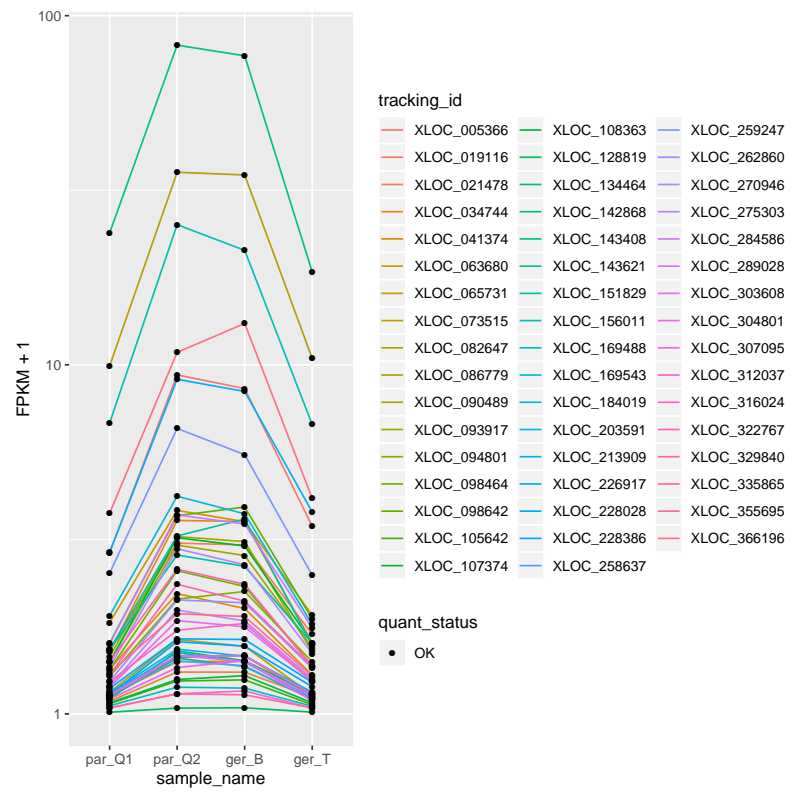

Figura A.37: Genes co-expressos com gene ScPAL4 no transcriptoma de cana-de-açúcar. Dados do transcriptoma de cana-de-acúcar de [Li et al., 2016]. Apresentação de 49 genes com expressão similar ao gene ScPAL4 (4769.3 | XLOC_082647) Linhas: Identificador dos genes no Genescpace de cana-de-açúcar SP80-3280. Colunas: Amostras avaliadas.

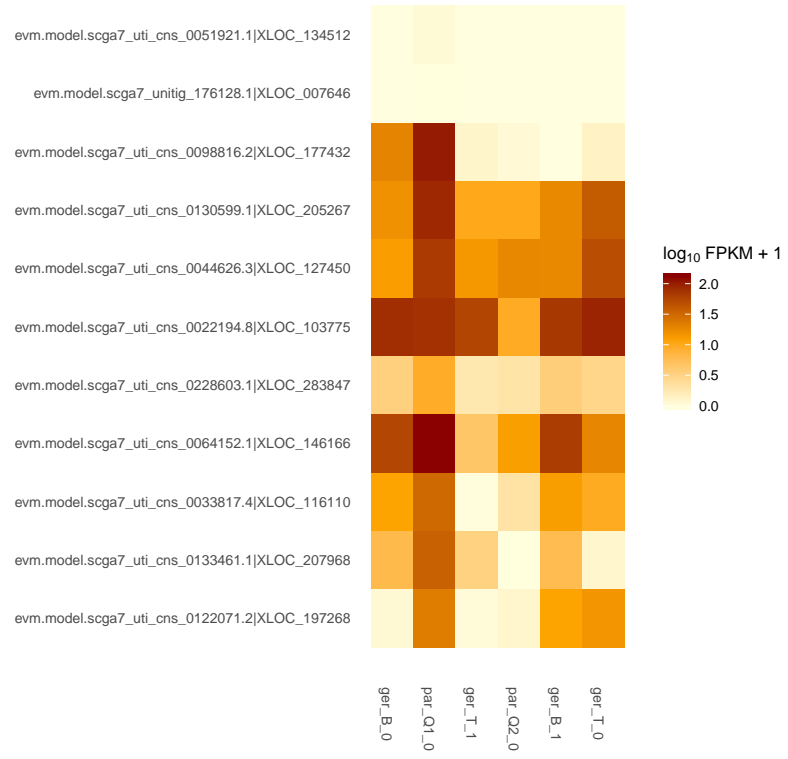

Figura A.38: Expressão da família gênica ScPAL5 no transcriptoma de cana-de-açúcar. Expressão gênica de sequências homo/homeólogas da família de genes ScPAL5 no transcriptoma de cana-de-açúcar [Li et al., 2016]. Linhas: Identificador dos genes no Genescpace de cana-de-açúcar SP80-3280. Colunas: Amostras avaliadas. 


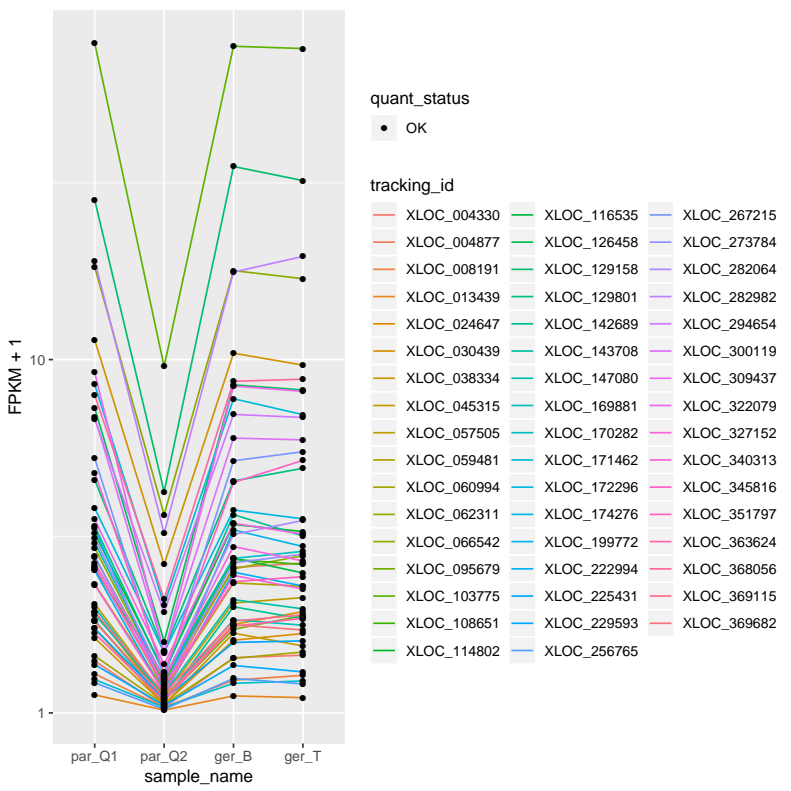

Figura A.39: Genes co-expressos com gene ScPAL5 no transcriptoma de cana-de-açúcar. Dados do transcriptoma de cana-de-acúcar de [Li et al., 2016]. Apresentação de 49 genes com expressão similar ao gene ScPAL5 (22194.8 | XLOC_103775) Linhas: Identificador dos genes no Genescpace de cana-de-açúcar SP80-3280. Colunas: Amostras avaliadas. 
Tabela A.3: Duração do processo de predição do TSSFinder em diferentes organismos

\begin{tabular}{|c|c|c|c|c|c|}
\hline & subgrupo_1 & subgrupo_2 & subgrupo_3 & subgrupo_4 & subgrupo_ \\
\hline athaliana.0 & $16 \min 39 \mathrm{~s}$ & $16 \mathrm{~min} 28 \mathrm{~s}$ & $16 \mathrm{~min} 33 \mathrm{~s}$ & $16 \mathrm{~min} 30 \mathrm{~s}$ & $16 \mathrm{~min} 25 \mathrm{~s}$ \\
\hline athaliana.1 & $16 \mathrm{~min} 35 \mathrm{~s}$ & $16 \mathrm{~min} 32 \mathrm{~s}$ & $16 \mathrm{~min} 38 \mathrm{~s}$ & $16 \mathrm{~min} 30 \mathrm{~s}$ & $16 \mathrm{~min} 26 \mathrm{~s}$ \\
\hline athaliana.2 & $16 \mathrm{~min} 37 \mathrm{~s}$ & $16 \mathrm{~min} 38 \mathrm{~s}$ & $16 \mathrm{~min} 30 \mathrm{~s}$ & $16 \mathrm{~min} 31 \mathrm{~s}$ & $16 \mathrm{~min} 29 \mathrm{~s}$ \\
\hline athaliana.3 & $16 \min 39 \mathrm{~s}$ & $16 \mathrm{~min} 36 \mathrm{~s}$ & $16 \mathrm{~min} 30 \mathrm{~s}$ & $16 \mathrm{~min} 32 \mathrm{~s}$ & $16 \mathrm{~min} 28 \mathrm{~s}$ \\
\hline athaliana.4 & $16 \mathrm{~min} 36 \mathrm{~s}$ & $16 \mathrm{~min} 38 \mathrm{~s}$ & $16 \mathrm{~min} 34 \mathrm{~s}$ & $16 \mathrm{~min} 28 \mathrm{~s}$ & $16 \mathrm{~min} 31 \mathrm{~s}$ \\
\hline
\end{tabular}

$\begin{array}{llllll}\text { Dmelanogaster.0 } & 9 \min 02 \mathrm{~s} & 8 \min 42 \mathrm{~s} & 9 \min 06 \mathrm{~s} & 9 \min 03 \mathrm{~s} & 9 \min 00 \mathrm{~s} \\ \text { Dmelanogaster.1 } & 40 \min 46 \mathrm{~s} & 5 \min 35 \mathrm{~s} & 5 \min 35 \mathrm{~s} & 6 \min 31 \mathrm{~s} & 6 \min 54 \mathrm{~s} \\ \text { Dmelanogaster.2 } & 5 \min 40 \mathrm{~s} & 5 \min 37 \mathrm{~s} & 5 \min 42 \mathrm{~s} & 5 \min 44 \mathrm{~s} & 5 \min 41 \mathrm{~s} \\ \text { Dmelanogaster.3 } & 5 \min 42 \mathrm{~s} & 5 \min 43 \mathrm{~s} & 5 \min 45 \mathrm{~s} & 5 \min 43 \mathrm{~s} & 5 \min 45 \mathrm{~s} \\ \text { Dmelanogaster.4 } & 5 \min 40 \mathrm{~s} & 5 \min 42 \mathrm{~s} & 5 \min 43 \mathrm{~s} & 5 \min 46 \mathrm{~s} & 5 \min 48 \mathrm{~s}\end{array}$

$\begin{array}{llllll}\text { Hsapiens.0 } & 23 \min 59 \mathrm{~s} & 23 \min 48 \mathrm{~s} & 23 \min 41 \mathrm{~s} & 24 \min 13 \mathrm{~s} & 24 \min 01 \mathrm{~s} \\ \text { Hsapiens.1 } & 24 \min 08 \mathrm{~s} & 24 \min 09 \mathrm{~s} & 24 \min 09 \mathrm{~s} & 24 \min 07 \mathrm{~s} & 24 \min 10 \mathrm{~s} \\ \text { Hsapiens.2 } & 24 \min 03 \mathrm{~s} & 24 \min 08 \mathrm{~s} & 24 \min 06 \mathrm{~s} & 23 \min 49 \mathrm{~s} & 23 \min 44 \mathrm{~s} \\ \text { Hsapiens.3 } & 23 \min 55 \mathrm{~s} & 23 \min 58 \mathrm{~s} & 23 \min 50 \mathrm{~s} & 23 \min 56 \mathrm{~s} & 23 \min 48 \mathrm{~s} \\ \text { Hsapiens.4 } & 23 \min 52 \mathrm{~s} & 24 \min 12 \mathrm{~s} & 24 \min 07 \mathrm{~s} & 24 \min 02 \mathrm{~s} & 23 \min 39 \mathrm{~s}\end{array}$

$\begin{array}{llllll}\text { Gallus gallus.0 } & 9 \min 04 \mathrm{~s} & 9 \min 07 \mathrm{~s} & 9 \min 07 \mathrm{~s} & 9 \min 08 \mathrm{~s} & 9 \min 07 \mathrm{~s} \\ \text { Gallus gallus.1 } & 9 \min 08 \mathrm{~s} & 9 \min 06 \mathrm{~s} & 9 \min 09 \mathrm{~s} & 9 \min 07 \mathrm{~s} & 9 \min 06 \mathrm{~s} \\ \text { Gallus gallus.2 } & 9 \min 05 \mathrm{~s} & 9 \min 05 \mathrm{~s} & 9 \min 07 \mathrm{~s} & 9 \min 05 \mathrm{~s} & 9 \min 03 \mathrm{~s} \\ \text { Gallus gallus.3 } & 9 \min 01 \mathrm{~s} & 8 \min 59 \mathrm{~s} & 9 \min 04 \mathrm{~s} & 8 \min 58 \mathrm{~s} & 9 \min 02 \mathrm{~s} \\ \text { Gallus gallus.4 } & 9 \min 05 \mathrm{~s} & 9 \min 10 \mathrm{~s} & 9 \min 07 \mathrm{~s} & 9 \min 01 \mathrm{~s} & 9 \min 05 \mathrm{~s}\end{array}$

$\begin{array}{llllll}\text { S. cerevisiae. } & 7 \min 23 \mathrm{~s} & 7 \min 21 \mathrm{~s} & 7 \min 21 \mathrm{~s} & 7 \min 24 \mathrm{~s} & 7 \min 25 \mathrm{~s} \\ \text { S. cerevisiae.1 } & 7 \min 28 \mathrm{~s} & 7 \min 26 \mathrm{~s} & 7 \min 18 \mathrm{~s} & 7 \min 18 \mathrm{~s} & 7 \min 27 \mathrm{~s} \\ \text { S. cerevisiae.2 } & 7 \min 27 \mathrm{~s} & 7 \min 26 \mathrm{~s} & 7 \min 28 \mathrm{~s} & 7 \min 28 \mathrm{~s} & 7 \min 23 \mathrm{~s} \\ \text { S. cerevisiae.3 } & 7 \min 29 \mathrm{~s} & 7 \min 20 \mathrm{~s} & 7 \min 25 \mathrm{~s} & 7 \min 25 \mathrm{~s} & 7 \min 21 \mathrm{~s} \\ \text { S. cerevisiae.4 } & 7 \min 25 \mathrm{~s} & 7 \min 28 \mathrm{~s} & 7 \min 23 \mathrm{~s} & 7 \min 27 \mathrm{~s} & 7 \min 28 \mathrm{~s}\end{array}$

$\begin{array}{llllll}\text { S. pombe.0 } & 2 \min 18 \mathrm{~s} & 3 \min 18 \mathrm{~s} & 3 \min 19 \mathrm{~s} & 3 \min 19 \mathrm{~s} & 3 \min 20 \mathrm{~s} \\ \text { S. pombe.1 } & 2 \min 17 \mathrm{~s} & 3 \min 19 \mathrm{~s} & 3 \min 18 \mathrm{~s} & 3 \min 20 \mathrm{~s} & 3 \min 21 \mathrm{~s} \\ \text { S. pombe.2 } & 2 \min 12 \mathrm{~s} & 3 \min 14 \mathrm{~s} & 3 \min 13 \mathrm{~s} & 3 \min 13 \mathrm{~s} & 3 \min 12 \mathrm{~s} \\ \text { S. pombe. } & 3 \min 33 \mathrm{~s} & 3 \min 08 \mathrm{~s} & 3 \min 08 \mathrm{~s} & 3 \min 08 \mathrm{~s} & 3 \min 10 \mathrm{~s} \\ \text { S. pombe.4 } & 2 \min 14 \mathrm{~s} & 3 \min 16 \mathrm{~s} & 3 \min 10 \mathrm{~s} & 3 \min 07 \mathrm{~s} & 3 \min 13 \mathrm{~s}\end{array}$

\begin{tabular}{llllll} 
Osativa.0 & $36 \min 50 \mathrm{~s}$ & $36 \min 59 \mathrm{~s}$ & $36 \min 57 \mathrm{~s}$ & $36 \min 56 \mathrm{~s}$ & $36 \min 54 \mathrm{~s}$ \\
Osativa.1 & $19 \min 52 \mathrm{~s}$ & $19 \min 49 \mathrm{~s}$ & $19 \min 55 \mathrm{~s}$ & $19 \min 52 \mathrm{~s}$ & $20 \mathrm{~min} 17 \mathrm{~s}$ \\
Osativa.2 & $36 \min 24 \mathrm{~s}$ & $36 \min 21 \mathrm{~s}$ & $36 \min 13 \mathrm{~s}$ & $36 \min 12 \mathrm{~s}$ & $36 \min 10 \mathrm{~s}$ \\
Osativa.3 & $20 \min 01 \mathrm{~s}$ & $19 \min 51 \mathrm{~s}$ & $20 \min 01 \mathrm{~s}$ & $20 \min 09 \mathrm{~s}$ & $20 \min 01 \mathrm{~s}$ \\
Osativa.4 & $36 \min 18 \mathrm{~s}$ & $36 \min 20 \mathrm{~s}$ & $36 \min 32 \mathrm{~s}$ & $36 \min 18 \mathrm{~s}$ & $36 \min 24 \mathrm{~s}$ \\
\hline
\end{tabular}


Tabela A.4: Duração do processo de treinamento do TSSFinder em diferentes organismos

\begin{tabular}{|c|c|c|c|c|c|}
\hline & subgrupo_1 & subgrupo_2 & subgrupo_3 & subgrupo_4 & subgrupo_5 \\
\hline A. thaliana & $255 \mathrm{~h} 22 \mathrm{~min} 28 \mathrm{~s}$ & $255 \mathrm{~h} 22 \mathrm{~min} 22 \mathrm{~s}$ & $255 \mathrm{~h} 22 \mathrm{~min} 25 \mathrm{~s}$ & $255 \mathrm{~h} 22 \mathrm{~min} 16 \mathrm{~s}$ & $255 \mathrm{~h} 22 \mathrm{~min} 17 \mathrm{~s}$ \\
\hline D. melanogaster & $59 \mathrm{~h} 08 \mathrm{~min} 52 \mathrm{~s}$ & $81 \mathrm{~h} 40 \mathrm{~min} 58 \mathrm{~s}$ & $74 \mathrm{~h} 33 \mathrm{~min} 29 \mathrm{~s}$ & $68 \mathrm{~h} 33 \mathrm{~min} 03 \mathrm{~s}$ & $74 \mathrm{~h} 46 \mathrm{~min} 48 \mathrm{~s}$ \\
\hline H. sapiens & $84 \mathrm{~h} 22 \mathrm{~min} 41 \mathrm{~s}$ & $85 \mathrm{~h} 06 \mathrm{~min} 55 \mathrm{~s}$ & 107h 55min 05s & $89 \mathrm{~h} 28 \mathrm{~min} 15 \mathrm{~s}$ & $93 \mathrm{~h} 39 \mathrm{~min} 15 \mathrm{~s}$ \\
\hline G. gallus & $22 \mathrm{~h} 05 \mathrm{~min} 28 \mathrm{~s}$ & $36 \mathrm{~h} 48 \mathrm{~min} 09 \mathrm{~s}$ & $29 \mathrm{~h} 17 \mathrm{~min} 38 \mathrm{~s}$ & $23 \mathrm{~h} 07 \mathrm{~min} 46 \mathrm{~s}$ & $31 \mathrm{~h} 23 \mathrm{~min} 37 \mathrm{~s}$ \\
\hline S. cerevisiae & $20 \mathrm{~h} 22 \mathrm{~min} 21 \mathrm{~s}$ & $19 \mathrm{~h} 46 \mathrm{~min} 24 \mathrm{~s}$ & $18 \mathrm{~h} 30 \mathrm{~min} 15 \mathrm{~s}$ & $23 \mathrm{~h} 48 \mathrm{~min} 36 \mathrm{~s}$ & $18 \mathrm{~h} 38 \mathrm{~min} 54 \mathrm{~s}$ \\
\hline S. pombe & $41 \mathrm{~h} 06 \mathrm{~min} 43 \mathrm{~s}$ & $39 \mathrm{~h} 47 \mathrm{~min} 55 \mathrm{~s}$ & $49 \mathrm{~h} 36 \mathrm{~min} 20 \mathrm{~s}$ & $34 \mathrm{~h} 24 \mathrm{~min} 40 \mathrm{~s}$ & $54 \mathrm{~h} 30 \mathrm{~min} 20 \mathrm{~s}$ \\
\hline O. sativa & $558 \mathrm{~h} 57 \mathrm{~min} 10 \mathrm{~s}$ & $472 \mathrm{~h} 43 \mathrm{~min} 27 \mathrm{~s}$ & $503 \mathrm{~h} 08 \mathrm{~min} 10 \mathrm{~s}$ & $519 \mathrm{~h} 18 \mathrm{~min} 13 \mathrm{~s}$ & $507 \mathrm{~h} 20 \mathrm{~min} 14 \mathrm{~s}$ \\
\hline
\end{tabular}


Tabela A.5: Resultado de predição do TSSFinder em A.thaliana considerando diferentes janelas de nucleotídeos

\begin{tabular}{|c|c|c|c|c|c|}
\hline $50 \mathrm{nt}$ & Subgrupo_1 & Subgrupo_2 & Subgrupo_3 & Subgrupo_4 & Subgrupo_5 \\
\hline Modelo_1 & 0 & 10606 & 10687 & 10634 & 10627 \\
\hline Modelo_2 & 10627 & 0 & 10657 & 10667 & 10605 \\
\hline Modelo_3 & 10530 & 10566 & 0 & 10572 & 10549 \\
\hline Modelo_4 & 10625 & 10704 & 10737 & 0 & 10674 \\
\hline Modelo_5 & 10517 & 10526 & 10570 & 10529 & 0 \\
\hline
\end{tabular}

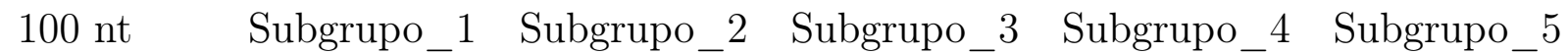

\begin{tabular}{llllll}
\hline Modelo_1 & 0 & 13145 & 13176 & 13161 & 13128 \\
Modelo_2 & 13054 & 0 & 13088 & 13096 & 13037 \\
Modelo_3 & 12993 & 13028 & 0 & 13034 & 12992 \\
Modelo_4 & 13085 & 13165 & 13158 & 0 & 13126 \\
Modelo_5 & 13113 & 13140 & 13151 & 13141 & 0 \\
\hline
\end{tabular}

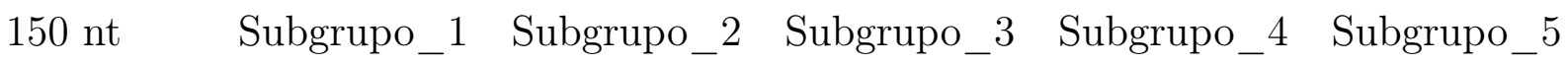

\begin{tabular}{llllll}
\hline Modelo_1 & 0 & 13550 & 13571 & 13541 & 13537 \\
Modelo_2 & 13905 & 0 & 13942 & 13933 & 13896 \\
Modelo_3 & 13433 & 13467 & 0 & 13450 & 13423 \\
Modelo_4 & 13508 & 13582 & 13579 & 0 & 13546 \\
Modelo_5 & 13524 & 13561 & 13564 & 13551 & 0 \\
\hline
\end{tabular}

$200 \mathrm{nt}$ Subgrupo_1 Subgrupo_2 Subgrupo_3 Subgrupo_4 Subgrupo_5

\begin{tabular}{|c|c|c|c|c|c|}
\hline Modelo_1 & 0 & 13799 & 13801 & 13782 & 13775 \\
\hline Modelo_2 & 14315 & 0 & 14355 & 14330 & 14316 \\
\hline Modelo_3 & 13689 & 13721 & 0 & 13697 & 13676 \\
\hline Modelo_4 & 13780 & 13849 & 13836 & 0 & 13817 \\
\hline Modelo_5 & 13771 & 13806 & 13793 & 13800 & 0 \\
\hline $250 \mathrm{nt}$ & Subgrupo_1 & Subgrupo_2 & Subgrupo_3 & Subgrupo_4 & Subgrupo_5 \\
\hline Modelo_1 & 0 & 14854 & 14850 & 14854 & 14837 \\
\hline Modelo_2 & 14571 & 0 & 14607 & 14579 & 14572 \\
\hline Modelo_3 & 14799 & 14815 & 0 & 14792 & 14777 \\
\hline Modelo_4 & 14819 & 14866 & 14846 & 0 & 14853 \\
\hline Modelo_5 & 14818 & 14831 & 14819 & 14822 & 0 \\
\hline
\end{tabular}


Tabela A.6: Resultado de predição do TSSFinder em D. melanogaster considerando diferentes janelas de nucleotídeos

$50 \mathrm{nt} \quad$ Subgrupo_1 Subgrupo_2 $\quad$ Subgrupo_3 $\quad$ Subgrupo_4 Subgrupo_5

\begin{tabular}{llllll}
\hline Modelo_1 & 0 & 1427 & 1437 & 1441 & 1418 \\
Modelo_2 & 1431 & 0 & 1426 & 1444 & 1411 \\
Modelo_3 & 1417 & 1410 & 0 & 1428 & 1393 \\
Modelo_4 & 1434 & 1457 & 1415 & 0 & 1380 \\
Modelo_5 & 1378 & 1438 & 1421 & 1425 & 0 \\
\hline
\end{tabular}

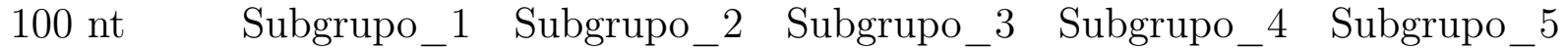

\begin{tabular}{llllll}
\hline Modelo_1 & 0 & 1816 & 1790 & 1761 & 1795 \\
Modelo_2 & 1763 & 0 & 1780 & 1773 & 1786 \\
Modelo_3 & 1754 & 1808 & 0 & 1758 & 1785 \\
Modelo_4 & 1760 & 1817 & 1768 & 0 & 1772 \\
Modelo_5 & 1726 & 1804 & 1772 & 1774 & 0 \\
\hline
\end{tabular}

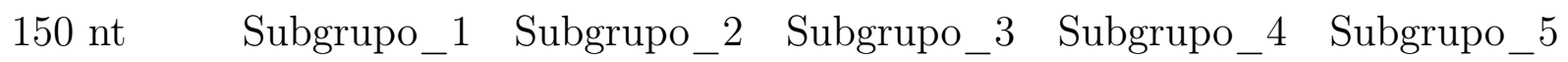

\begin{tabular}{llllll}
\hline Modelo_1 & 0 & 2006 & 2011 & 1963 & 1998 \\
Modelo_2 & 1977 & 0 & 2000 & 1978 & 1996 \\
Modelo_3 & 1972 & 2018 & 0 & 1977 & 2006 \\
Modelo_4 & 1966 & 2002 & 1994 & 0 & 1975 \\
Modelo_5 & 1945 & 2002 & 2003 & 1983 & 0 \\
\hline
\end{tabular}

$200 \mathrm{nt} \quad$ Subgrupo_1 Subgrupo_2 $\quad$ Subgrupo_3 $\quad$ Subgrupo_4 Subgrupo_5

\begin{tabular}{|c|c|c|c|c|c|}
\hline Modelo_1 & 0 & 2128 & 2139 & 2117 & 2122 \\
\hline Modelo_2 & 2109 & 0 & 2133 & 2124 & 2128 \\
\hline Modelo_3 & 2110 & 2147 & 0 & 2123 & 2126 \\
\hline Modelo 4 & 2092 & 2136 & 2125 & 0 & 2111 \\
\hline Modelo_5 & 2077 & 2125 & 2141 & 2121 & 0 \\
\hline $250 \mathrm{nt}$ & Subgrupo_1 & Subgrupo_2 & Subgrupo_3 & Subgrupo_4 & Subgrupo_5 \\
\hline Modelo_1 & 0 & 2249 & 2245 & 2230 & 2248 \\
\hline Modelo_2 & 2240 & 0 & 2248 & 2237 & 2254 \\
\hline Modelo_3 & 2229 & 2258 & 0 & 2237 & 2260 \\
\hline Modelo_4 & 2220 & 2245 & 2241 & 0 & 2229 \\
\hline Modelo_5 & 2205 & 2238 & 2252 & 2230 & 0 \\
\hline
\end{tabular}


Tabela A.7: Resultado de predição do TSSFinder em S. cerevisiae considerando diferentes janelas de nucleotídeos

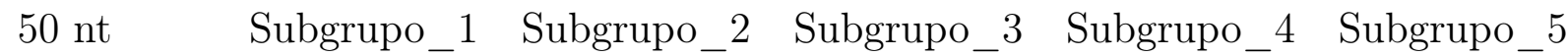

\begin{tabular}{llllll}
\hline Modelo_1 & 0 & 732 & 727 & 746 & 724 \\
Modelo_2 & 741 & 0 & 730 & 744 & 730 \\
Modelo_3 & 751 & 738 & 0 & 749 & 744 \\
Modelo_4 & 740 & 747 & 740 & 0 & 749 \\
Modelo_5 & 736 & 738 & 724 & 754 & 0 \\
\hline
\end{tabular}

$100 \mathrm{nt} \quad$ Subgrupo_1 Subgrupo_2 $\quad$ Subgrupo_3 $\quad$ Subgrupo_4 Subgrupo_5

\begin{tabular}{llllll}
\hline Modelo_1 & 0 & 906 & 885 & 903 & 899 \\
Modelo_2 & 888 & 0 & 890 & 905 & 891 \\
Modelo_3 & 900 & 893 & 0 & 904 & 895 \\
Modelo_4 & 897 & 903 & 896 & 0 & 901 \\
Modelo_5 & 893 & 892 & 891 & 910 & 0 \\
\hline
\end{tabular}

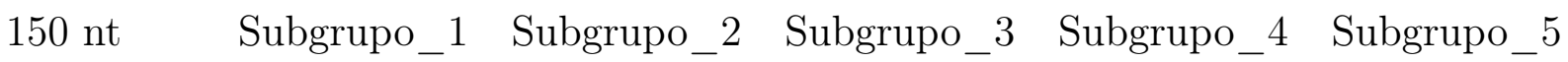

\begin{tabular}{llllll}
\hline Modelo_1 & 0 & 937 & 935 & 937 & 934 \\
Modelo_2 & 936 & 0 & 935 & 937 & 934 \\
Modelo_3 & 937 & 937 & 0 & 937 & 935 \\
Modelo_4 & 935 & 937 & 935 & 0 & 934 \\
Modelo_5 & 935 & 937 & 934 & 937 & 0 \\
\hline
\end{tabular}

$200 \mathrm{nt}$ Subgrupo_1 Subgrupo_2 Subgrupo_3 Subgrupo_4 Subgrupo_5

\begin{tabular}{llllll}
\hline Modelo_1 & 0 & 937 & 935 & 937 & 934 \\
Modelo_2 & 936 & 0 & 935 & 937 & 935 \\
Modelo_3 & 937 & 937 & 0 & 937 & 936 \\
Modelo_4 & 935 & 937 & 935 & 0 & 935 \\
Modelo_5 & 935 & 937 & 935 & 937 & 0 \\
\hline \multicolumn{7}{l}{ 250 nt } & Subgrupo_1 & Subgrupo_2 & Subgrupo_3 & Subgrupo_4 & Subgrupo_5 \\
\multicolumn{7}{l}{ Modelo_1 } & 0 & 937 & 935 & 937 & 934 \\
Modelo_2 & 936 & 0 & 935 & 937 & 935 \\
Modelo_3 & 937 & 937 & 0 & 937 & 936 \\
Modelo_4 & 935 & 937 & 935 & 0 & 936 \\
Modelo_5 & 935 & 937 & 935 & 937 & 0 \\
\hline
\end{tabular}




\section{Referências Bibliográficas}

Abeel, T., Van de Peer, Y., and Saeys, Y. (2009). Toward a gold standard for promoter prediction evaluation. Bioinformatics, 25(12):i313-i320. 15, 16

Adelman, K. and Lis, J. T. (2012). Promoter-proximal pausing of rna polymerase ii: emerging roles in metazoans. Nature Reviews Genetics, 13(10):720-731. 10, 11, 13

Bailey, T. L., Boden, M., Buske, F. A., Frith, M., Grant, C. E., Clementi, L., Ren, J., Li, W. W., and Noble, W. S. (2009). Meme suite: tools for motif discovery and searching. Nucleic acids research, page gkp335. 19, 23, 32, 34

Begcy, K., Mariano, E. D., Gentile, A., Lembke, C. G., Zingaretti, S. M., Souza, G. M., and Menossi, M. (2012). A novel stress-induced sugarcane gene confers tolerance to drought, salt and oxidative stress in transgenic tobacco plants. PloS one, 7(9):e44697. 27, 49, 73, 74

Capella, M., Ré, D. A., Arce, A. L., and Chan, R. L. (2014). Plant homeodomain-leucine zipper i transcription factors exhibit different functional aha motifs that selectively interact with tbp or/and tfiib. Plant cell reports, 33(6):955-967. 13

Cardoso-Silva, C. B., Costa, E. A., Mancini, M. C., Balsalobre, T. W. A., Canesin, L. E. C., Pinto, L. R., Carneiro, M. S., Garcia, A. A. F., de Souza, A. P., and Vicentini, R. (2014). De novo assembly and transcriptome analysis of contrasting sugarcane varieties. PloS one, 9(2):e88462. 7, 28, 29, 30, 48, 86, 87, 88, 89, 90, 91, 92, 93, 94, 95

Cheavegatti-Gianotto, A., de Abreu, H. M. C., Arruda, P., Bespalhok Filho, J. C., Burnquist, W. L., Creste, S., di Ciero, L., Ferro, J. A., de Oliveira Figueira, A. V., de Sousa Filgueiras, T., et al. (2011). Sugarcane (saccharum x officinarum): a reference study for the regulation of genetically modified cultivars in brazil. Tropical plant biology, 4(1):62-89. 1, 3, 4, 6

Chiang, D. Y., Moses, A. M., Kellis, M., Lander, E. S., and Eisen, M. B. (2003). Phylogenetically and spatially conserved word pairs associated with gene-expression changes in yeasts. Genome biology, 4(7):1. 22

Claeys, M., Storms, V., Sun, H., Michoel, T., and Marchal, K. (2012). Motifsuite: workflow for probabilistic motif detection and assessment. Bioinformatics, 28(14):1931-1932. 32, 33,34

CONAB (2018). Conab | acompanhamento da safra brasileira de cana-de-aÇÚcar | v. 5 safra 2018/19, n.1 - primeiro levantamento, maio de 2018. Brasília: CONAB, 5(1):1-62. $1,4,5$ 
Cui, D., Zhao, J., Jing, Y., Fan, M., Liu, J., Wang, Z., Xin, W., and Hu, Y. (2013). The arabidopsis idd14, idd15, and idd16 cooperatively regulate lateral organ morphogenesis and gravitropism by promoting auxin biosynthesis and transport. PLoS Genetics, 9(9):e1003759. 45

Cumbie, J. S., Ivanchenko, M. G., and Megraw, M. (2015). Nanocage-xl and capfilter: an approach to genome wide identification of high confidence transcription start sites. $B M C$ genomics, 16(1):597. 15

de los Reyes, B. G., Mohanty, B., Yun, S. J., Park, M.-R., and Lee, D.-Y. (2015). Upstream regulatory architecture of rice genes: summarizing the baseline towards genus-wide comparative analysis of regulatory networks and allele mining. Rice, 8(1):1. 8, 10, 17, 74

De Setta, N., Monteiro-Vitorello, C. B., Metcalfe, C. J., Cruz, G. M. Q., Del Bem, L. E., Vicentini, R., Nogueira, F. T. S., Campos, R. A., Nunes, S. L., Turrini, P. C. G., et al. (2014). Building the sugarcane genome for biotechnology and identifying evolutionary trends. BMC genomics, 15(1):540. 6, 7

de Siqueira Ferreira, S., Nishiyama, M. Y., Paterson, A. H., and Souza, G. M. (2013). Biofuel and energy crops: high-yield saccharinae take center stage in the post-genomics era. Genome biology, 14(6):1. 2, 4, 7

Delmas, F., Sankaranarayanan, S., Deb, S., Widdup, E., Bournonville, C., Bollier, N., Northey, J. G., McCourt, P., and Samuel, M. A. (2013). Abi3 controls embryo degreening through mendel's i locus. Proceedings of the National Academy of Sciences, page 201308114. 45

Dinardo-Miranda, L. L., de Vasconcellos, A. C. M., and de Andrade Landell, M. G. (2008). Cana-de-açúcar. Instituto Agronômico Campinas. 1, 2, 3, 4

Dolfini, D., Zambelli, F., Pavesi, G., and Mantovani, R. (2009). A perspective of promoter architecture from the ccaat box. Cell Cycle, 8(24):4127-4137. 14

Dreos, R., Ambrosini, G., Groux, R., Cavin Périer, R., and Bucher, P. (2016). The eukaryotic promoter database in its 30th year: focus on non-vertebrate organisms. Nucleic acids research, 45(D1):D51-D55. 11, 15, 16, 30, 31, 38, 74, 79, 80

Durbin, R., Eddy, S. R., Krogh, A., and Mitchison, G. (1998). Biological sequence analysis: probabilistic models of proteins and nucleic acids. Cambridge university press. 19, 20, 23, 24

Edwards, D., Stajich, J., and Hansen, D. (2009). Bioinformatics: tools and applications. Springer Science \& Business Media. 9, 10, 19, 20, 21, 23

FAOstat, F. (2018). Statistical database of food and agriculture organisation of the united nations. http://www.fao.org/faostat/en/. Ultimo acesso 26/05/2018. 5

Ferreira, S. S., Hotta, C. T., de Carli Poelking, V. G., Leite, D. C. C., Buckeridge, M. S., Loureiro, M. E., Barbosa, M. H. P., Carneiro, M. S., and Souza, G. M. (2016). Coexpression network analysis reveals transcription factors associated to cell wall biosynthesis in sugarcane. Plant molecular biology, 91(1-2):15-35. 6, 27, 29, 46, 77 
Franco-Zorrilla, J. M., López-Vidriero, I., Carrasco, J. L., Godoy, M., Vera, P., and Solano, R. (2014). Dna-binding specificities of plant transcription factors and their potential to define target genes. Proceedings of the National Academy of Sciences, 111(6):2367-2372. $9,18,74,75$

Franco-Zorrilla, J. M. and Solano, R. (2017). Identification of plant transcription factor target sequences. Biochimica et Biophysica Acta (BBA)-Gene Regulatory Mechanisms, 1860(1):21-30. 9, 18, 19, 75

Fujimoto, S. Y., Ohta, M., Usui, A., Shinshi, H., and Ohme-Takagi, M. (2000). Arabidopsis ethylene-responsive element binding factors act as transcriptional activators or repressors of gcc box-mediated gene expression. The Plant Cell, 12(3):393-404. 48

Gusmão, E. G., Dieterich, C., and Costa, I. G. (2012). Prediction of transcription factor binding sites by integrating dnase digestion and histone modification. In Brazilian Symposium on Bioinformatics, pages 109-119. Springer. 24, 25, 26

Hagen, G. and Guilfoyle, T. (2002). Auxin-responsive gene expression: genes, promoters and regulatory factors. Plant molecular biology, 49(3-4):373-385. 48

Heinz, S., Benner, C., Spann, N., Bertolino, E., Lin, Y. C., Laslo, P., Cheng, J. X., Murre, C., Singh, H., and Glass, C. K. (2010). Simple combinations of lineage-determining transcription factors prime cis-regulatory elements required for macrophage and b cell identities. Molecular cell, 38(4):576-589. 22

Holoch, D. and Moazed, D. (2015). Rna-mediated epigenetic regulation of gene expression. Nature Reviews Genetics, 16(2):71-84. 8

Hotta, C. T., Nishiyama Jr, M. Y., and Souza, G. M. (2013). Circadian rhythms of sense and antisense transcription in sugarcane, a highly polyploid crop. PloS one, 8(8):e71847. 6

Kang, J.-y., Choi, H.-i., Im, M.-y., and Kim, S. Y. (2002). Arabidopsis basic leucine zipper proteins that mediate stress-responsive abscisic acid signaling. The Plant Cell, 14(2):343357. 45,47

Kaufmann, K., Pajoro, A., and Angenent, G. C. (2010). Regulation of transcription in plants: mechanisms controlling developmental switches. Nature Reviews Genetics, 11(12):830842. 17

Keung, A. J., Joung, J. K., Khalil, A. S., and Collins, J. J. (2015). Chromatin regulation at the frontier of synthetic biology. Nature Reviews Genetics, 16(3):159-171. 8

Khan, A., Fornes, O., Stigliani, A., Gheorghe, M., Castro-Mondragon, J. A., van der Lee, R., Bessy, A., Cheneby, J., Kulkarni, S. R., Tan, G., et al. (2017). Jaspar 2018: update of the open-access database of transcription factor binding profiles and its web framework. Nucleic acids research, 46(D1):D260-D266. 34, 42, 45, 47, 48, 50, 76, 77, 78

Kumari, S. and Ware, D. (2013). Genome-wide computational prediction and analysis of core promoter elements across plant monocots and dicots. PloS one, 8(10):e79011. 12, 13, $14,16,46,76,77$

Ladunga, I. (2010). Computational biology of transcription factor binding. Springer. 7, 8, 9, $10,16,19,20,21,23$ 
Lafferty, J., McCallum, A., and Pereira, F. C. (2001). Conditional random fields: Probabilistic models for segmenting and labeling sequence data. 35, 36

Lembke, C. G. (2013). Identificação de genes e promotores relacionados ao estresse de seca em cana-de-açúcar e obtenção de plantas transgênicas. $\mathrm{PhD}$ thesis, Universidade de São Paulo. 73

Lembke, C. G., Nishiyama Jr, M. Y., Sato, P. M., de Andrade, R. F., and Souza, G. M. (2012). Identification of sense and antisense transcripts regulated by drought in sugarcane. Plant molecular biology, 79(4-5):461-477. 29, 30

Levo, M. and Segal, E. (2014). In pursuit of design principles of regulatory sequences. Nature Reviews Genetics, 15(7):453-468. 7, 8, 9, 10, 11, 13, 17, 18

Li, M., Liang, Z., Zeng, Y., Jing, Y., Wu, K., Liang, J., He, S., Wang, G., Mo, Z., Tan, F., et al. (2016). De novo analysis of transcriptome reveals genes associated with leaf abscission in sugarcane (saccharum officinarum 1.). BMC genomics, 17(1):1. 7, 28, 29, 30, 48, 49, 100, 101, 102, 103, 104, 105

MacQuarrie, K. L., Fong, A. P., Morse, R. H., and Tapscott, S. J. (2011). Genome-wide transcription factor binding: beyond direct target regulation. Trends in Genetics, 27(4):141148. 17

Mathelier, A. and Wasserman, W. W. (2013). The next generation of transcription factor binding site prediction. PLoS Comput Biol, 9(9):e1003214. 24, 25

Meier, S., Gehring, C., MacPherson, C. R., Kaur, M., Maqungo, M., Reuben, S., Muyanga, S., Shih, M.-D., Wei, F.-J., Wanchana, S., et al. (2008). The promoter signatures in rice lea genes can be used to build a co-expressing lea gene network. Rice, 1(2):177-187. 17, $22,74,75$

Mejía-Guerra, M. K., Li, W., Galeano, N. F., Vidal, M., Gray, J., Doseff, A. I., and Grotewold, E. (2015). Core promoter plasticity between maize tissues and genotypes contrasts with predominance of sharp transcription initiation sites. The Plant Cell, 27(12):33093320. 11, 12, 13, 14, 15, 16, 74

Morton, T., Petricka, J., Corcoran, D. L., Li, S., Winter, C. M., Carda, A., Benfey, P. N., Ohler, U., and Megraw, M. (2014). Paired-end analysis of transcription start sites in arabidopsis reveals plant-specific promoter signatures. The Plant Cell, pages tpc-114. 14, 15

Morton, T., Wong, W.-K., and Megraw, M. (2015). Tipr: transcription initiation pattern recognition on a genome scale. Bioinformatics, 31(23):3725-3732. 11, 13, 14, 15, 16, 37, 53,79

Mount, D. W. (2004). Sequence and genome analysis. Bioinformatics: Cold Spring Harbour Laboratory Press: Cold Spring Harbour, 2. 19, 20, 23, 24

Nakashima, K., Yamaguchi-Shinozaki, K., and Shinozaki, K. (2014). The transcriptional regulatory network in the drought response and its crosstalk in abiotic stress responses including drought, cold, and heat. Abiotic Stress: Molecular Genetics and Genomics, page 25. 17 
Narlikar, L. and Ovcharenko, I. (2009). Identifying regulatory elements in eukaryotic genomes. Briefings in functional genomics and proteomics, 8(4):215-230. 14, 15, 16

Ni, T., Corcoran, D. L., Rach, E. A., Song, S., Spana, E. P., Gao, Y., Ohler, U., and Zhu, J. (2010). A paired-end sequencing strategy to map the complex landscape of transcription initiation. Nature methods, 7(7):521. 14, 15

Nishiyama, M., Vicente, F., Lembke, C., Sato, P., Dal-Bianco, M., Fandino, R., Hotta, C., and Souza, G. (2010). The sucest-fun regulatory network database: designing an energy grass. In Proc. Int. Soc. Sugar Cane Technol, volume 27, pages 1-10. 6, 29

Nishiyama, M. Y., Ferreira, S. S., Tang, P.-Z., Becker, S., Pörtner-Taliana, A., and Souza, G. M. (2014). Full-length enriched cdna libraries and orfeome analysis of sugarcane hybrid and ancestor genotypes. PloS one, 9(9):e107351. 7, 28, 29, 30, 48, 49, 75, 76

Papini-Terzi, F. S., Rocha, F. R., Vêncio, R. Z., Felix, J. M., Branco, D. S., Waclawovsky, A. J., Del Bem, L. E., Lembke, C. G., Costa, M. D., Nishiyama, M. Y., et al. (2009). Sugarcane genes associated with sucrose content. BMC genomics, 10(1):120. 6

Pouteau, S., Carré, I., Gaudin, V., Ferret, V., Lefebvre, D., and Wilson, M. (2008). Diversification of photoperiodic response patterns in a collection of early-flowering mutants of arabidopsis. Plant physiology, 148(3):1465-1473. 45

Rawat, R., Schwartz, J., Jones, M. A., Sairanen, I., Cheng, Y., Andersson, C. R., Zhao, Y., Ljung, K., and Harmer, S. L. (2009). Reveille1, a myb-like transcription factor, integrates the circadian clock and auxin pathways. Proceedings of the national academy of sciences, 106(39):16883-16888. 45

Rombauts, S., Florquin, K., Lescot, M., Marchal, K., Rouzé, P., and Van de Peer, Y. (2003). Computational approaches to identify promoters and cis-regulatory elements in plant genomes. Plant physiology, 132(3):1162-1176. 10, 12, 20, 21

Sakai, H., Lee, S. S., Tanaka, T., Numa, H., Kim, J., Kawahara, Y., Wakimoto, H., Yang, C.-c., Iwamoto, M., Abe, T., et al. (2013). Rice annotation project database (rap-db): an integrative and interactive database for rice genomics. Plant and Cell Physiology, 54(2):e6-e6. 15, 79

Salvini, M., Sani, E., Fambrini, M., Pistelli, L., Pucciariello, C., and Pugliesi, C. (2012). Molecular analysis of a sunflower gene encoding an homologous of the b subunit of a caat binding factor. Molecular biology reports, 39(6):6449-6465. 14

Schultheiss, S. J., Busch, W., Lohmann, J., Kohlbacher, O., and Rätsch, G. (2009). Kirmes: kernel-based identification of regulatory modules in euchromatic sequences. $B M C$ Bioinformatics, 10(13):1. 22, 75

Shahmuradov, I. A., Umarov, R. K., and Solovyev, V. V. (2017). Tssplant: a new tool for prediction of plant pol ii promoters. Nucleic acids research, 45(8):e65-e65. 11, 13, 14, 15, $16,32,37,38,53,79$

Shiraki, T., Kondo, S., Katayama, S., Waki, K., Kasukawa, T., Kawaji, H., Kodzius, R., Watahiki, A., Nakamura, M., Arakawa, T., et al. (2003). Cap analysis gene expression for high-throughput analysis of transcriptional starting point and identification of promoter usage. Proceedings of the National Academy of Sciences, 100(26):15776-15781. 11, 14, 15, 16 
Shlyueva, D., Stampfel, G., and Stark, A. (2014). Transcriptional enhancers: from properties to genome-wide predictions. Nature Reviews Genetics, 15(4):272-286. 8, 17, 18

Siddharthan, R., Siggia, E. D., and Van Nimwegen, E. (2005). Phylogibbs: a gibbs sampling motif finder that incorporates phylogeny. PLoS Comput Biol, 1(7):e67. 22

Smith, N. C. and Matthews, J. M. (2016). Mechanisms of dna-binding specificity and functional gene regulation by transcription factors. Current opinion in structural biology, 38:68-74. 18, 19

Souza, G. M., Berges, H., Bocs, S., Casu, R., D’Hont, A., Ferreira, J. E., Henry, R., Ming, R., Potier, B., Van Sluys, M.-A., et al. (2011). The sugarcane genome challenge: strategies for sequencing a highly complex genome. Tropical plant biology, 4(3-4):145-156. 4, 6,7

Souza, G. M., Victoria, R. L., Joly, C. A., and Verdade, L. M. (2015). Bioenergy \& sustainability: bridging the gaps. SCOPE, Paris. ISBN, pages 978-2. 2

Spitz, F. and Furlong, E. E. (2012). Transcription factors: from enhancer binding to developmental control. Nature Reviews Genetics, 13(9):613-626. 7, 8, 10, 11, 17, 18

Stormo, G. D. and Zhao, Y. (2010). Determining the specificity of protein-dna interactions. Nature Reviews Genetics, 11(11):751. 18, 19

Thirugnanasambandam, P. P., Hoang, N. V., and Henry, R. J. (2018). The challenge of analyzing the sugarcane genome. Frontiers in plant science, 9. 3, 4, 6, 7, 74

Tokizawa, M., Kusunoki, K., Koyama, H., Kurotani, A., Sakurai, T., Suzuki, Y., Sakamoto, T., Kurata, T., and Yamamoto, Y. Y. (2017). Identification of arabidopsis genic and nongenic promoters by paired-end sequencing of tss tags. The Plant Journal, 90(3):587-605. 14,15

Trapnell, C., Williams, B. A., Pertea, G., Mortazavi, A., Kwan, G., Van Baren, M. J., Salzberg, S. L., Wold, B. J., and Pachter, L. (2010). Transcript assembly and quantification by rna-seq reveals unannotated transcripts and isoform switching during cell differentiation. Nature biotechnology, 28(5):511. 28

UNICA, U. d. A. C. d. (2018). Estado de são paulo, site corporativo. http://www.unica. com.br/. Ultimo acesso 26052018. 1, 2

Vettore, A. L., da Silva, F. R., Kemper, E. L., Souza, G. M., da Silva, A. M., Ferro, M. I. T., Henrique-Silva, F., Giglioti, É. A., Lemos, M. V., Coutinho, L. L., et al. (2003). Analysis and functional annotation of an expressed sequence tag collection for tropical crop sugarcane. Genome research, 13(12):2725-2735. 6

Vicentini, R., Bottcher, A., dos Santos Brito, M., dos Santos, A. B., Creste, S., de Andrade Landell, M. G., Cesarino, I., and Mazzafera, P. (2015). Large-scale transcriptome analysis of two sugarcane genotypes contrasting for lignin content. PloS one, 10(8):e0134909. 7, 28, 29, 30, 48

Vilela, M. d. M., Del Bem, L. E., Van Sluys, M.-A., de Setta, N., Kitajima, J. P., Cruz, G. M. Q., Sforça, D. A., de Souza, A. P., Ferreira, P. C. G., Grativol, C., et al. (2017). Analysis of three sugarcane homo/homeologous regions suggests independent polyploidization events of saccharum officinarum and saccharum spontaneum. Genome biology and evolution, 9(2):266-278. 4, 6, 7, 74 
Villar, D., Flicek, P., and Odom, D. T. (2014). Evolution of transcription factor binding in metazoans-mechanisms and functional implications. Nature reviews. Genetics, 15(4):221233. $7,8,9,11$

Watson, J. D., Baker, T. A., Bell, S. P., Gann, A., Levine, M., and Losicke, R. (2015). Biologia molecular do gene. Artmed Editora. 7, 8, 9, 10, 13, 14, 17

Yamamoto, Y. Y., Ichida, H., Abe, T., Suzuki, Y., Sugano, S., and Obokata, J. (2007a). Differentiation of core promoter architecture between plants and mammals revealed by ldss analysis. Nucleic acids research, 35(18):6219-6226. 14, 21

Yamamoto, Y. Y., Ichida, H., Matsui, M., Obokata, J., Sakurai, T., Satou, M., Seki, M., Shinozaki, K., and Abe, T. (2007b). Identification of plant promoter constituents by analysis of local distribution of short sequences. BMC genomics, 8(1):1. 13, 14

Yamamoto, Y. Y., Yoshioka, Y., Hyakumachi, M., and Obokata, J. (2011). Characteristics of core promoter types with respect to gene structure and expression in arabidopsis thaliana. DNA research, page dsr020. 13, 14

Yamamoto, Y. Y., Yoshitsugu, T., Sakurai, T., Seki, M., Shinozaki, K., and Obokata, J. (2009). Heterogeneity of arabidopsis core promoters revealed by high-density tss analysis. The Plant Journal, 60(2):350-362. 11, 12

Yanagisawa, S. and Schmidt, R. J. (1999). Diversity and similarity among recognition sequences of dof transcription factors. The Plant Journal, 17(2):209-214. 48

Yu, C.-P., Chen, S. C.-C., Chang, Y.-M., Liu, W.-Y., Lin, H.-H., Lin, J.-J., Chen, H. J., Lu, Y.-J., Wu, Y.-H., Lu, M.-Y. J., et al. (2015). Transcriptome dynamics of developing maize leaves and genomewide prediction of cis elements and their cognate transcription factors. Proceedings of the National Academy of Sciences, 112(19):E2477-E2486. 17, 19, 20

Zambelli, F., Pesole, G., and Pavesi, G. (2012). Motif discovery and transcription factor binding sites before and after the next-generation sequencing era. Briefings in bioinformatics, page bbs016. 17, 21

Zeng, Y. and Yang, T. (2002). Rna isolation from highly viscous samples rich in polyphenols and polysaccharides. Plant Molecular Biology Reporter, 20(4):417-417. 30

Zhang, J., Arro, J., Chen, Y., and Ming, R. (2013). Haplotype analysis of sucrose synthase gene family in three saccharum species. BMC genomics, 14(1):314. 27, 43, 75 